\title{
ARGONNE NATIONAL LABORATORY-EAST SITE ENVIRONMENTAL REPORT FOR CALENDAR YEAR 1990
}

by

N. W. Golchert, T. L. Duffy, and L. P. Moos

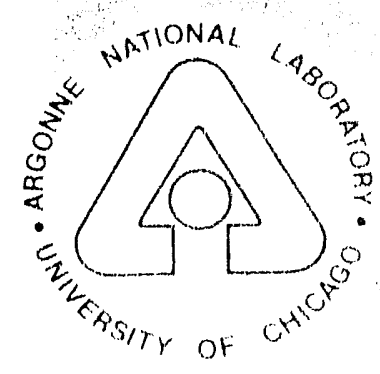

ARGONNE NATIONAL LABORATOFY, ARGONNE, ILLIINOIS

Operated by THE UNIVERSITY OF CHICAGO

for the U.S. DEPARTMENT OF ENERGY

under Contract W-31-109-Eng-38 
Argonne National Laboratory, with facilities in the states of Illinos and Idaho, is owned by the United States government, and operated by The University of Chicago under the provisions of a contract with the Department of Energy.

\section{DISCLAIMER}

Thi:: report wats prepared ats an account of work sponsored by an agency of the United States Govermment. Neither the United States Government nor any agency thereof, nor any of their employees, makes any warranty, express or implied, or atsumes any legall liability or responsibility for the accuracy, completeness, or usefulness of any information, apparatus, product, or process disclosed, or represents that its use would not infringe privaldely owned rights. Reference herein to any specifie commercial product, process, or service by trade name, Mademark, manufacturer, or otherwise, does not necessartily constifute or imply its endorsement, recommendation, or fitvoring by the United States Government or any agency thereof. The views and opinions of authors expressed herein do not necessarily state or reflect those of the United States Government or any agency thereof.

Reproduced from the best available copy.

Available 10 DOE and DOE conlactors from the

Oflice of Scientific and Technical Information

P.(). Box 02

()ik Ridge, TN 378.31

Prices available from (61.5) 576-840)1, FTS 626-840)

Available to the public from the

Nattonal Technical Information Service

IISS. Department of Commerce

528.5 Port Royal Road

Springficld, V^ 22161 


\section{ANL $-91 / 3$}

\begin{tabular}{lc}
\multicolumn{2}{l}{ ANL- $91 / 3$} \\
ARGONNE NATIONAL LABORATORY & DE92 012282 \\
9700 South Cass Avenue & \\
Argonne, Illinois 6043.9 &
\end{tabular}

ARGONNE NATIONAL LABORATORY-EAST SITE ENVIRONMENTAL REPORT

FOR CALENDAR YEAR 1990

by

N. W. Golchert, T. L. Duffy, and L. P. Moos

Environment, Safety and Health Division

Laboratory Work Performed by
T. L. Duffy
D. M. Ray
N. W. Golchert
A. S. Reeve
R. B. Kasper
J. G. Riha
N. D. Kretz
V. C. Stamoudis
L. P. Moos
T. M. Sullivan

H. C. Sroboda

July 1991 


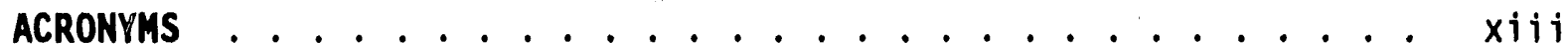

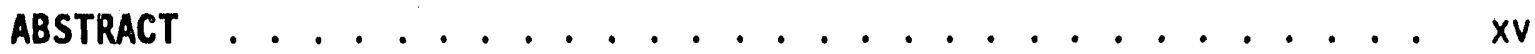

EXECUTIVE SUMMARY ................... X XVii

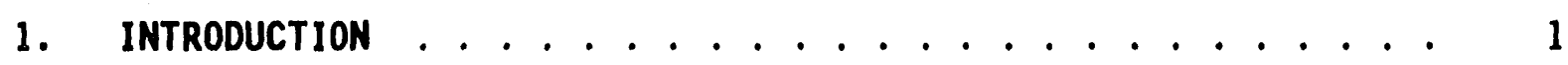

1.1. General ................. 1

1.2. Description of Site ............. 3

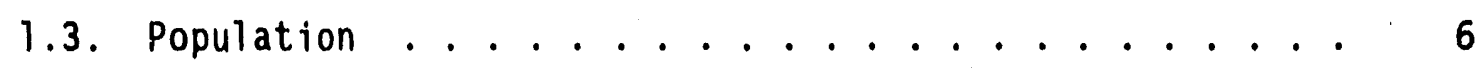

1.4. Climatology .................. 8

1.5. Geohydrology ................ 10

1.6. Water and Land Use ............ . . 12

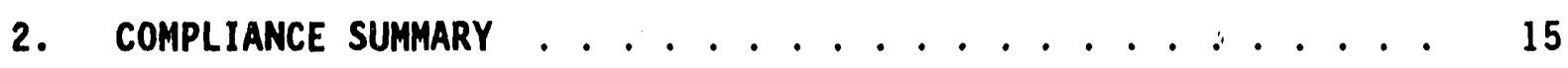

2.1. Clean Air Act . . . . . . . . . . . . . . 15

2.1.1. National Emission Standards for Hazardous

Air Pollutants . . . . . . . . . . 16

2.1.1.1. Asbestos Emissions ........ . . 16

2.1.1.2. Radionuclide Emissions ...... 18

2.1.2. Conventional Air Pollutants ......... 20

2.2. Clean Water Act . . . . . . . . . . . . 21

2.2.1. Liquid Effluent Discharge Permit ...... 22

2.2.1.1. Effluent Monitoring Results

2.2.1.2. Additional NPDES Monitoring ..... 28

2.2.2. Stormwater Regulations . . . . . . . . 29

2.2.3. NPDES Inspections and Audits ........ 29

2.2.4. General Effluent and Stream Quality Standards . . 29

2.2.5. NPDES Analytical Quality Assurance ...... 30

2.2.6. Spill Prevention Control and

Countermeasures Plan ......... 30 


\section{TABLE OF CONTENTS}

Page

2.3. Resource Conservation and Recovery Act ......... . 31

2.3.1. Hazardous Waste Treatment and Disposal . . . . 31

2.3.2. Permit Status.... . . . . . . . . . . 32

2.3.3. Hazardous Waste Generation . . . . . . . . 34

2.3.4. Facility Modifications ........... . 34

2.3.5. Mixed Waste Handling .. . . . . . . . . 35

2.3.6. RCRA Inspections . . . . . . . . . . 35

2.3.7. Underground Storage Tanks... . . . . . . 35

2.3.8. Corrective Action for Solid Waste
Management Units . . . . . . . . . 36 36

2.4 Solid Waste Disposal . . . . . . . . . . . . . . . 37

2.5. National Environmental Policy Act . . . . . . . . . . . 37

2.6. Safe Drinking Water Act . . . . . . . . . . . . . 39

2.6.1. Applicability to ANL ........... 40

2.6.2. Monitoring Requirements............ 40

2.7. Federal Insecticide, Fungicide and
Rodenticide Act . . . . . . . . . . . . . . 40

2.8. Comprehensive Environmental Response, Compensation
and Liability Act...................... 41

2.8.1. CERCLA Program at ANL ............ . 41

2.8.2. CERCLA Remedial Actions............ 43

2.8.3. Emergency Planning and Community
Right to Know Act, SARA Title III........ 44

2.9. Toxic Substances Control Act . . . . . . . . . . . . . 44

2.9.1. PCBs in Use at ANL ............. 46

2.10. Endangered Species Act . . . . . . . . . . . . . 47

2.11. National Historic Preservation AcC . . . . . . . . . . 48

2.12. Flood Plain Management . . . . . . . . . . . . 48

2.13. Protection of Wetlands ............... . 49

2.14. Current Issues and Actions . . . . . . . . . . . . 50

2.14.1. Major Compliance Issues .. . . . . . . . 50

2.14.2. Regulatory Agency Interactions . . . . . . . 51

2.14.3. Tiger Team Assessment . . . . . . . . . . 51

2.15. Environmental Permits.............. . 53 
Page

2.16. Compliance Summary for the First Quarter of 1991 . . . . 53

2.16.1. Clean Air Act .............. . 53

2.16.2. Clean Water Act . . . . . . . . . . . . 56

2.16.3. Resource Conservation and Recovery Act . . . . 56

2.16.4. National Environmental Policy Act . . . . . . 57

2.16.5. Safe Drinking Water Act . . . . . . . . . . 57

2.16.6. Federal Insecticide, Fungicide
and Rodenticide Act . . . . . . . . . 57

2.16.7. Comprehensive Enviornmental Response,
Compensation and Liability Act . . . . . . 57

2.16.8. Permits . . . . . . . . . . . . . 57

3. ENVIRONMENTAL PROGRAM INFORMATION . . . . . . . . . . . . . 59

3.1. Environmental Restoration and Waste Management Program . 59

3.1.1. Corrective Actions ............. 60

3.1.2. Environmental Restoration Activities ..... 60

3.1.3. Waste Management . . . . . . . . . . . . 62

3.2. Pollution Prevention Program . . . . . . . . . . . 63

3.3. Environmental Monitoring Program Description . . . . . 64

3.3.1. Air Sampling .............. . 64

3.3.2. Water Sampling . . . . . . . . . . . 66

3.3.3. Bottom Sediment... . . . . . . . . . 67

3.3.4. Soil . . . . . . . . . . . . . . . 68

3.3.5. Vegetation ............... 69

3.3.6. Exterral Penetrating Radiation . . . . . . . 70

4. ENVIRONMENTAL RAD $/$ OLOGICAL PROGRAM INFORMATION . . . . . . . 71

4.1. Descriptioll of Monitoring Program . . . . . . . . . . . . 71

4.2. Air... . . . . . . . . . . . . . . . . 72

4.3. Surface Water. . . . . . . . . . . . . . . . 82

4.4. Soil, Grass, and Bottom Sediment .......... . 85

4.5. Milk . . . . . . . . . . . . . . . . . . . . . . . 91

4.6. External Penetrating Radiation . . . . . . . . . . 94 
4.7. Estimates of Potential Radiation Doses . . . . . . 98

4.7.1. Airborne Pathway . . . . . . . . . . . . 99

4.7.2. Water Pathway . . . . . . . . . . . . . 118

4.7.3. External Direct Radiation Pathway . . . . . . 120

4.7.4. Dose Summary ................ 121

5. ENVIRONMENTAL NONRADIOLOGICAL PROGRAM INFORMATION . . . . . . 123

5.1. National Pollutant Discharge Elimination System

Monitoring Results . . . . . . . . . . . . . 123

5.1.1. Sample Collection.............. 128

5.1.2. Results............... 129

5.2. Additional Effluent Monitoring . . . . . . . . . 139

5.2.1. Sample Collection............. 139

5.2.2. Results.................. . 139

5.3. Sawmill Creek. . . . . . . . . . . . . . . 139

5.3.1. Sample Collection............... 141

5.3.2. Results.................. 141

5.4. Des Plaines River................. 141

6. GROUNDWATER PROTECTION . . . . . . . . . . . . . . . 143

6.1. Potable Water System . . . . . . . . . . . . . . 143

6.2 Groundwater Monitoring at Waste Management Sites . . . 145

6.2.1. 317/319 Area ................. . 147

6.2.2. Groundwater Monitoring at the $317 / 319$ Area . . . 149

6.2.2.1. Sample Collection......... 151

6.2.2.2. Sample Analysis.......... . 152

6.2.2.3. Results of Analyses.......... 152

6.3. Sanitary Landfill . . . . . . . . . . . . . . . . . 172

6.3.1. French Drain . . . . . . . . . . . . . 172

6.3.2. Monitoring Studies ............. 173

6.3.2.1. Sample Collection......... 173

6.3.2.2. Results of Analyses......... 175 


\section{TABLE OF CONTENTS}

Page

6.4. CP-5 Reactor Area . . . . . . . . . . . 190

6.5. Site Characterization Activities ......... 192

6.5.1. 800 Area Landfill Characterization . . . . . 193

6.5.2. 317/319 Area Characterization......... 194

7. QualitY ASSURANCE . . . . . . . . . . . . . . . . 197

7.1. Radiochemical Analysis and Radioactivity 197 Measurements . . . . . . . . . . . . 197

7.2. Chemical Analysis.............. . . 199

8. APPENDIX ...................... 207

8.1. References .............. . . . 207

8.2. Acknowledgements ............ 210 


\section{LIST OF TABLES}

No.

Iitle

Page

1.1 Population Distribution in the Vicinity of ANL, 1991 . . . 7

1.2 ANL Weather Summary, $1990 \ldots . . . . . . . . .11$

2.1 Description of NPDES Outfalls at ANL ........... 23

2.2 Hazardous Waste Treatment and Storage Facilities....... 33

List of Inactive Disposal Sites at ANL
Described in Various CERCLA Reports ............. 42

2.4 Compounds Reported Under SARA Tit7e III . . . . . . . . 45

2.5 ANL Environmental Permits in Effect on December 31, 1990 . . 54

2.6 ANL Environmental Permits Obtained During 1990 ....... 55

2.7 ANL Environmental Permits Obtained During the
First Quarter of 1991 ....... 58

3.1 Environmental Restoration and Waste Management Projects ... 61

4.1 Total Alpha and Beta Activities in Air-Filter $\ldots$. . . . . . 74

4.2 Gamma-Ray Activity in Air-Filter Samples, $1990 \ldots 75$

4.3 Strontium, Thorium, Uranium, and Plutonium Concentrations in Air-Filter Samples, $1990 \ldots \ldots$. . . . . . . 78

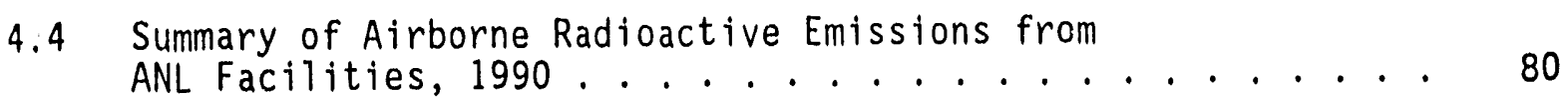

4.5 Tritiated Water Vapor in Air, $1990 \ldots . . . . . . . .81$

4.6 Radionuclides in Sawmill Creek Water, 1990 . . . . . . . 84

4.7 Total Radioactivity Released to Sawmill Creek. 1990 . . . . . 85

4.8 Radionuclides in Des Plaines River Water, $1990 \ldots 86$

4.9 Radionuclides in Illinois River Water, $1990 \ldots . . . . .87$

4.10 Gamma-Ray Emitting Radionuclides in Soil, 1990 . . . . . . 89

4.11 Transuranics in Soil, 1990 .............. 90

4.12 Radionuclides in Grass, 1990 ... . . . . . . . . . . 92

4.13 Radionuclides in Bottom Sediment, 1990 ........ . 93

4.14 Strontium-90 in Milk, 1990 ... . . . . . . . . . . . . 94

4.15 Environmental Penetrating Radiation at Off-Site
Locations, 1990 ......................... 35

4.16 Environmental Penetrating Radiation at ANL, $1990 \ldots 96$ 


\section{LIST OF TABLES}

No.

4.17 Radiological Airborne Releases from

Buildings 200 and 211,1990 ............... 100

4.18 Maximum Perimeter and Individual Doses from

Buildings 200 and 211 Air Emissions, 1990 ......... 101

4.19 Radiological Airborne Releases from

Building 202 (JANUS), 1990 ............... 102

4.20 Maximum Perimeter and Individual Doses from

Building 202 (JANUS) Air Emissions, 1990 .......... 103

4.21 Radiological Airborne Releases from Building 205, 1990 . . . . 104

4.22 Maximum Perimeter and Individual Doses from

Building 205 Air Emissions, 1990 ... . . . . . . . . . 105

4.23 Radiological Airborne Releases from Building 212, 1990 . . . 106

4.24 Maximum Perimeter and Individual Doses from Building 212 Air Emissions, 1990 ............. . 107

4.25 Radiological Airborne Releases from Building 330 (CP-5), 1990 ............... 108

4.26 Maximum Perimeter and Individual Doses from Building 330 (CP-5) Air Emissions, 1990 . . . . . . . . 109

4.27 Radiological Airborne Releases from Building 350, 1990 . . . . 110

4.28 Maximum Perimeter and Individual Doses from Building 350 Air Emissions, 1990 . . . . . . . . . . . 111

4.29 Radiological Airborne Releases from Building 375 (IPNS), 1990 .............. . 112

4.30 Maximum Perimeter and Individual Doses from Building 375 (IPNS) Air Emissions, 1990 . . . . . . . . 113

$4.3180-\mathrm{km}$ Population Dose, 1990 . . . . . . . . . . . . . 115

4.32 50-Year Committed Effective Dose Equivalent Factors - CEDE . . 117

4.33 Radionuclide Concentrations and Dose Estimates for Sawmill Creek Water, 1990 . . . . . . . . . . . . 120

4.34 Annual Average Dose Equivalent in the U. S. Population . . . . 122

5.1 NPDES Permit Limit Exceedances, 1990 . . . . . . . . . . 124

5.2 Outfall 001A Effluent Limits and Monitoring Results, 1990 . . 132

5.3 Outfall 001B Volatile Organic Carbon Monitoring Results, 1990 ................... 134

5.4 Volatile Organic Compounds in Laboratory Wastewater, 1990 . . 135

5.5 Outfall 010 Effluent Limits and Monitoring Results, 1990 . . 138 


\section{LIST OF TABLES}

№.

Iitle

Page

5.6 Chemical Constituents in Effluents from ANL

Wastewater Treatment P1ant, 1990.............. . 140

5.7 Chemical Constituents in Sawmill Creek, Location 7M, 1990 . 142

6.1 Safe Drinking Water Standards . . . . . . . . . . . . 144

6.2 Radioactivity in ANL Domestic Wells, 1990 . . . . . . . . 146

6.3 Target Compound List . . . . . . . . . . . . . . . . 153

6.4 Groundwater Monitoring Results, 300 Area
Well \#300010, 1990 . . . . . . . . . . . . . 155

6.5 Groundwater Monitoring Results, 300 Area 156

6.6 Groundwater Monitoring Results, 300 Area

6.7 Groundwater Monitoring Results, 300 Area
Well \#300031, $1990 .$. . . . . . . . . . . . 158

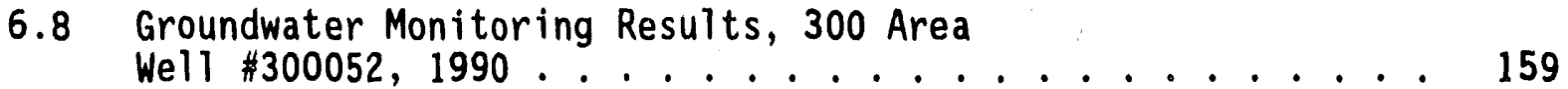

6.9 Groundwater Monitoring Results, 300 Area

6.10 Groundwater Monitoring Results, 300 Area
Well $\# 300100,1990$. . . . . . . . . . . . . 161

6.11 Groundwater Monitoring Results, 300 Area
Well \#300110, 1990.................... 162

6.12 Groundwater Monitoring Results, 300 Area
Well $\# 300120,1990$. . . . . . . . . . . . . . . 163

6.13 Groundwater Monitoring Results, 300 Area 164

6.14 Groundwater Monitoring Results, 300 Area

Well \#300003,1990................. 165

6.15 Groundwater Monitoring Results, 300 Area

Well \#300004, 1990 ................. 166

6.16 Groundwater Monitoring Results, Sanitary Landfill
Perimeter Well \#800012, 1990 . . . . . . . . . . . 176

6.17 Groundwater Monitoring Results, Sanitary Landfill

6.18 Groundwater Monitoring Results, Sanitary Landfill

Perimeter Well \#800030, 1990 . . . . . . . . . . . 178

6.19 Groundwater Monitoring Results, Sanitary Landfill

Perimeter Well \#800042, 1990 . . . . . . . . . . . 179 


\section{LIST OF TABLES}

No.

Iitle

Page

6.20 Groundwater Monitoring Results, Sanitary Landfill

Perimeter Wel1 \#800050, 1990 . . . . . . . . . . 180

6.21 Groundwater Monitoring Results, Sanitary Landfill

Perimeter We11 \#800060, $1990 \ldots . . . . . . .181$

6.22 Groundwater Monitoring Results, Sanitary Landfill

Perimeter We11 \#800071，1990 . . . . . . . . . . . . 182

6.23 Groundwater Monitoring Resuits, Sanitary Landfill

Perimeter Well \#800080, 1990 . . . . . . . . . . 183

6.24 Groundwater Monitoring Results, Sanitary Landfill

Perimeter Well \#800090, 1990 . . . . . . . . . . . 184

6.25 Groundwater Monitoring Results, Sanitary Landfill

Perimeter Wel1 \#800100, 1990 ........... 185

6.26 Groundwater Monitoring Results, Sanitary Landfill

Perimeter Wel1 \#800130, 1990 . . . . . . . . . . 186

6.27 Groundwater Monitoring Results, Sanitary Landfill

Perimeter Well \#800001, 1990 ............ 187

6.28 Groundwater Monitoring Results, Sanitary Landfill

Perimeter We11 \#800002, $1990 \ldots \ldots 188$

6.29 Groundwater Monitoring Results, 300 Area

Well \#330010，1990 ............... 191

7.1 Detection Limits . . . . . . . . . . . . . . . 198

7.2 Summary of EPA Samples, $1990 \ldots \ldots$. . . . . . . . . 200

7.3 Summary of DOE-EML-QAP Samples, $1990 \ldots \ldots 201$

7.4 NIST-SRM Used for Inorganic Analysis . . . . . . . . . 203

7.5 EPA Quality Check Sample Results, 1990 ........... 204

7.6 Summary of EPA Nonradiological Samples, $1990 \ldots 205$ 


\section{LIST OF FIGURES}

No.

Title

Page

1.1 Sampling Locations at Argonne National Laboratory . . . . . . . 4

1.2 Sampling Locations Near Argonne National Laboratory . . . . . . 5

1.3 Monthly and Annual Wind Roses at Argonne National Laboratory, 1990 . . . . . . . . . . . . . . 9 9

2.1 NPDES Permit Locations . . . . . . . . . . . . . . . . 24

2.2 Distribution of NPDES Permit Violations, 1990 . . . . . . . 26

4.1 Comparison of Total Alpha and Beta Activities in Perimeter Air-filter Samples ............. . 76

4.2 Comparison of Gamma-Ray Activity in Air-Filter Samples . . . . 76

4.3 Selected Airborne Radionuclide Emissions . . . . . . . . . . 79

4.4 Penetrating Radiation Measurements at the ANL Site, 1990 . . . 97

4.5 Individual and Perimeter Doses From Airborne
Radioactive Emissions . . . . . . . . . . . . . . . . . . . 114

4.6 Population Dose From Airborne Radioactive Emissions . . . . . . 116

4.7 Comparison of Dose Estimates From Ingestion of Sawmill Creek Water . . . . . . . . . . . . . . . . 119

5.1 ANL Sewage Treatment Plant . . . . . . . . . . . . . 126

5.2 NPUES Outfall Locations . . . . . . . . . . . . . . . 127

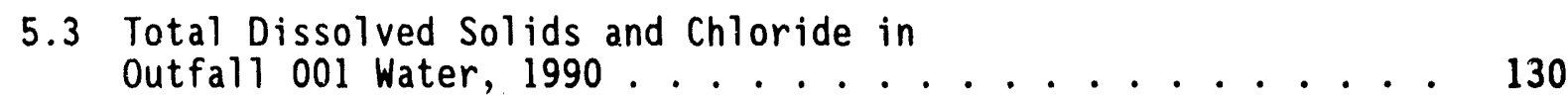

6.1 Location of Components Within the 317/319/ENE Area . . . . . 148

6.2 Monitoring Well Locations in the 317 and 319 Areas . . . . . . 150

6.3 Concentrations of $1,1,1-$ Trichloroethane and
1,1 -Dichloroethane in Well $\# 300020$. . . . . . . . . . . . . . 169

6.4 Concentrations of Trichloroethene and cis-1,2-Dichloroethine in Well \#300100, 1990 . . . . . . . 170

6.5 Monitoring Well Locations for Landfill in the 800 firea . . . . 174 
1,2-DCE Cis-1,2-Dichloroethene

ACM Asbestos Containing liaterials

ADS Activity lata Sheets

AEA Atomic lneryy Act

ALARA As low As Roasonably Achiovable

ANL

APS

ASTM

ATLAS

ATSR

BAT

BETX

$B O D$

CAA

CEDE

CERCLA

CFR

COD

CP-5

CWA

CWDD

$\mathrm{CY}$

$D \& D$

$D C G$

DMR

DOE

EA

EBWR

EIS

EML

EMS

ENE

EPA

ESA

ESH

ESH/QA

FEUL

FIFRA

FONSI

FWS

FY

GOCO

HEPA

HRS

HSWA

IAC

ICRP

IEPA

IHOM

INEL

Advanced Photon Source

Argonne Thermal Source Reactor

Best Available Technology

Biochemical Oxygen Demand

Clean Air Act

and Lability Aca

Code of lederal Regulations

Chemical oxygen Demand

Chicago pile..Five

Clean Water Act

Calendar Year

Derived Concentration Guides

Discharge Monitoring Report

U. S. Department of Energy

Enviromental Assessment

Environmental Impact Statement

East-Northeast

Endangered Species Act

Environment, Safety and Health

Fossil Energy Users Laboratory

Fish and Wildlife Service

Fiscal Year

High-Efficiency Particulate

Hazard Ranking Scores

111 inois Administrative Code
Argome National Laboratory tast

American society for lestince and liaterials

Argonne landem Linac Accelerating System

Benzene, Ethylbenzene, Toluene, and Xylene

Committed Effective Dose Equivalent

Comprehensive Envirommental Response, Comperisation

Continuous Wave Deuterium Demonstrator

Decontamination and Decommissiuring

Experimental Boiling Water Reactor

Environmental Measurements Laboratory

Enviromental Protection Data Management System

United States Environmental Protection Agency

Environment, Safety and Health/Quality Assurance

Federal Insecticide, Fungicide and Rodenticide Act

Finding of No Significant Impact

Government-owned contractor-operated

Hazardous and Solid Waste Admendments

International Commission on Radiological Protection

Illinois Environmental Protection Agency

Industrial Hygiene Operating Manual

Idaho National Engineering Laboratory
NBL

NCRP

NEPA

NESHAP

NHPA

NIST

NOAA

NOD

NOV

NPDES

NPL

OSHA

$P A$

PCB

PFS

PNA

PRP

QA

RCRA

SARA

SDWA

SI

SIP

SPCC

SRM

SSI

SWMU

TCA

TCE

TDS

TLD

TRU

TSCA

TSD

TSS

UST

VOC

WMO
Intemse linl Local l mery Maximume Lon Maximum Con Matgneto Hyd Material s Now brums, i National (o) Nal ional In National ton Nal iomal $11 \mathrm{i}$ National ln National () Notil(cer of Notice ol $V$ Nat ional P'o National Pr Occelpat iona preliminary polychlorin Plant lacil Polymaclear Potentially Dllality Ais Rosomerese Superfund $A$ Safe brinki site lovest State lmplo" Spill preve standard ke site Screen Solid Wa:lo $1,1,1,1$ rich Trichloroet lotal J)isso Thermolumin Transuranic Toxic Substl Treatment. Total Susper Underground Volatileor Waste Manlaty 


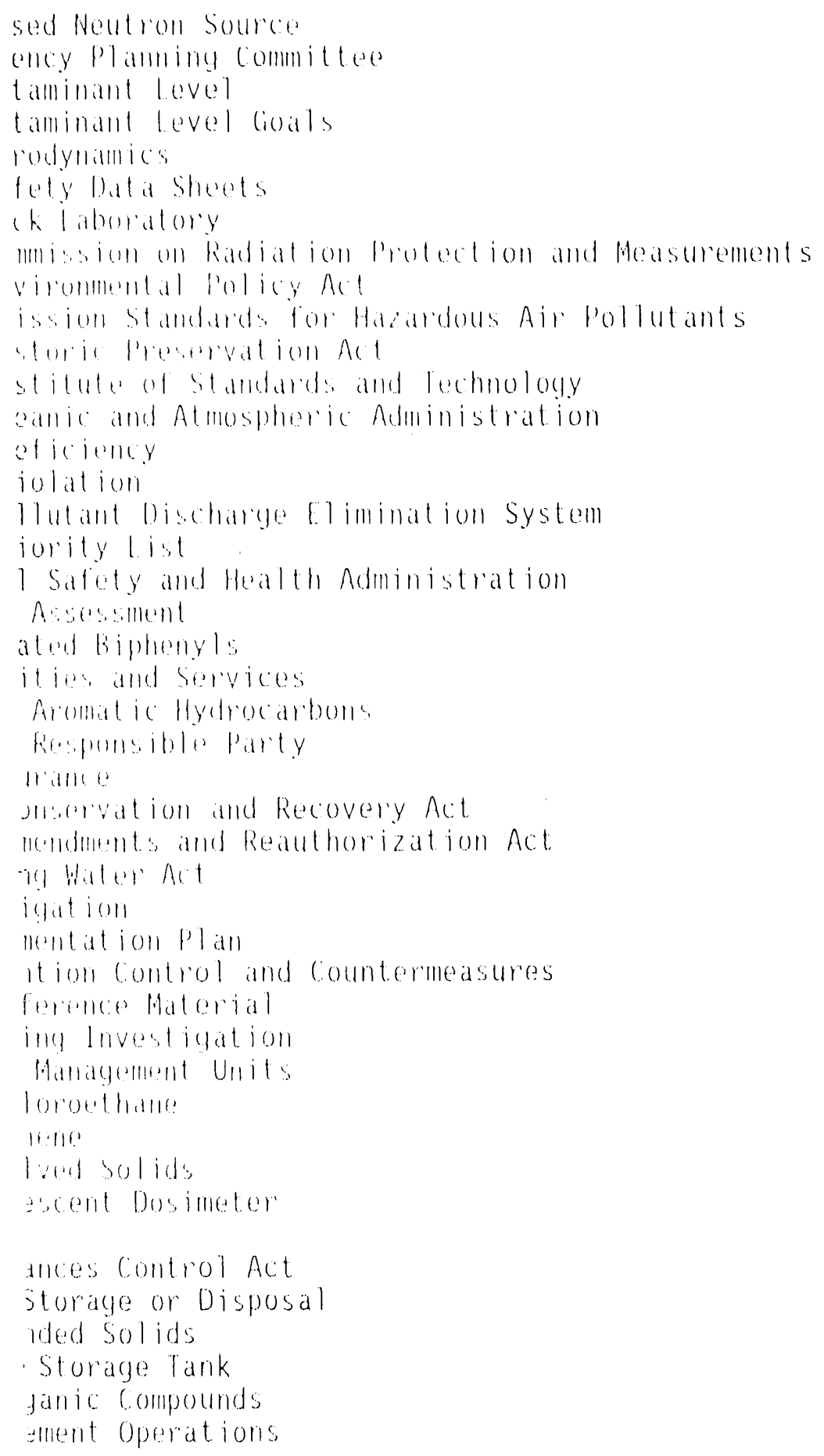


ARGONNE NATIONAL LABORATORY-EAST SITE ENVIRONMENTAL REPORT

FOR CALENDAR YEAR 1990

by

N. W. Golchert, T. L. Duffy, and L. P. Moos

\section{ABSTRACT}

This report discusses the results of the environmental protection program at Argonne National Laboratory-East (ANL) for 1990. To evaluate the effects of ANL operations on the environment, samples of environmental media collected on the site, at the site boundary, and off the ANL site were analyzed and compared to applicable guidelines and standards. A variety of radionuclides was measured in air, surface water, groundwater, soil, grass, bottom sediment, and milk samples. In addition, chemical constituents in surface water, groundwater, and ANL effluent water were analyzed. External pe etrating radiation doses were measured and the potential for radiation exposure to off-site population groups was estimated. The results of the surveillance program are interpreted in terms of the origin of the radioactive and chemical substances (natural, fallout, ANL, and other) and are compared with applicable environmental quality standards. A U. S. Department of Energy (DOE) dose calculation methodology, based on International Commission on Radiological Protection (ICRP) recommendations, is used in this report. The status of ANL environmental protection activities with respect to the various laws and regulations which govern waste handling and disposal is discussed. This report al so discusses progress being made on environmental corrective actions and restoration projects from past activities. 


\section{EXECUTIVE SUMMARY}

This report is a summary of the ongoing environmental protection program conducted by ANL in 1990. It includes descriptions of the site, the ANL missions and programs, the status of compliance with environmental regulations, environmental protection and restoration activities, and the environmental surveillance program. The surveillance program conducts regular monitoring for radiation, radioactive materials, and nonradiological constituents on the ANL site and in the surrounding region. These activities document compliance with appropriate standards and permit limits, identify trends, provide information to the public, and contribute to a better understanding of ANL's impact on the environment. The surveillance program supports the ANL policy to protect the public, employees, and the environment from harm that could be caused by ANL activities and to reduce environmental impacts to the greatest degree practicable.

\section{Compliance Summary}

Radionuclide emissions, the disposal of asbestos, and conventional air pollutants from ANL facilities are regulated under the Clean Air Act. A number of airborne radiological emission points at ANL are subject to the NESHAP regulations for radionuclide releases from DOE facilities (40 CFR 61, Subpart H). All such air emission sources were evaluated to ensure that the requirements were being properly addressed. The ANL individual off site dose required to be reported by these EPA regulations was $0.0091 \mathrm{mrem} / \mathrm{y}$ in 1990. This is $0.09 \%$ of the $10 \mathrm{mrem} / \mathrm{y}$ standard.

At ANL, asbestos-containing material is frequently encountered during a renovation or demolition project. Asbestos is removed in strict accordance with the NESHAP regulations as well as with the much stricter OSHA worker protection standards. All asbestos waste material is sealed in special plastic bags and disposed of in a designated section of the ANL landfi11. Approximately $65 \mathrm{~m}^{3}$ (2298 $\left.\mathrm{ft}^{3}\right)$ of asbestos or asbestos-contaminated materials were disposed of during 1990 in the sanitary landfill. 
The ANL site contains several sources of conventional air pollutants. The steam plant and fuel dispensing facilities operate continuously and represent the only significant sources of conventional air pollutants. The operating permit for the steam plant requires continuous opacity and sulfur dioxide monitoring of the smoke stack from Boiler No. 5, the only boiler equipped to burn coal. Coal was burned only during the first three months of 1990 whereas natural gas was used as a fuel for the rest of the year. During the period coal was burned, $19 \mathrm{SO}_{2} 1$ imit excursions and 371 opacity limit excursions were reported. As a result of excessive excursions of emission limits during 1989 and 1990, ANL received a CIL from the IEPA.

The regulatory mechanism designed to achieve the goals of the Clean Water Act is the National Pollutani Discharge Elimination System (NPDES). The authority to implement the NPDES program has been delegated to the State of Illinois. Nine surface water discharge points are regulated by the ANL NPDES permit which identifies the sampling locations, sampling frequency, constituents, and limits. In 1990, 91\% of the measurements were in compliance with the permit requirements. The major source of the exceedances, 55 for total dissolved solids and eight for chloride, were traced to the disposal of ion exchange regenerant solution into the wastewater treatment system. These exceedances should be eliminated when the piping is completed to divert this effluent to the DuPage County sewer system. A total of 11 exceedances of the total suspended solids limit occurred during 1990 due to buth soil erosion from precipitation run-off and operational problems. other exceedances occurred at various outfalls and covered a number of parameters.

ANL was granted interim status under the Resources Conservation and Recovery Act (RCRA) by submitting a Part A permit application in 1980 . In 1990, a Part B permit application was submitted to the IEPA. Twelve hazardous waste treatment and storage facilities were identified. The Part B permit application is currently under IEPA review.

In an effort to dispose of surplus and outdated chemicals, a site-wide cleanup program resulted in the disposal of 268,700 1iters $(71,000$ gallons) 
of hazardous wastes. In addition, 6578 liters (1738 galions) of waste were treated on-site, primarily by neutralization. Mixed wastes were stored or treated to remove the hazardous characteristics (e.g., by acid/base neutralization) before off-site disposal.

ANL has prepared and implemented a Site-Wide Underground Storage Tank Compliance Plan. At present, 33 tanks have been removed over the past several years and 25 tanks remain for removal or upgrade. Of the tanks removed, 15 were found to have some degree of exterior contamination from leaks, spills, or overfills. All but one of these contaminated sites were successfully cleaned and filled. One site required a "dirty" closure due to its proximity to a building.

In 1986, ten potential Comprehensive Environmental Response, Compensation and Liability Act (CERCLA) sites were identified. Under the Superfund Amendmenis and Reauthorization Act of 1986, a total of 15 PA reports were submitted. In late 1990 , SSI reports were completed on two individual sites and one composite submittal of three locations (317/319/ENE). Characterization studies are at various stages for a number of the identified sites. For some sites, the regulatory vehicle, CERCLA, RCRA, or some combination, has not as yet been established.

The only Toxic Substances Control Act (TSCA) compounds in significant quantities at ANL are polychlorinated biphenyls (PCBs) contained in electrical capacitors, transformer oil, and PCB-contaminated soil and sludge. During 1990, all pole-mounted transformers and circuit breakers containing PCBs were replaced or retrofilled with non-PCB 011 . All removal and disposal activities were conducted by licensed contractors specializing in such operations. A sludge drying bed, servicing the ANL wastewater treatment plant, was found to be contaminated with PCBs of unknown origin. An extensive characterization study and appropriate remediation of this site is planned.

The DOE implementation of the National Environmental Policy Act (NEPA) regulations has been undergoing significant changes during 1990 . This has 
resulted in the submission of a large number of NEPA project review documents to DOE for review and approval. Most of these were determined to be categorical exclusions although Environmental Assessments will be required for several projects. Construction of the Continuous Wave Deuterium Demonstrator (CWDD) will require the preparation of an EA. During 1990, a FONSI was issued for the APS project. There are currently no active projects at ANL for which an EIS is required.

The 1990 Five-Year Plan contained information of 181 separate projects. The on-site activities included 15 corrective action projects, 26 environmental restoration projects, and seven waste management activities. The corrective action projects concentrate on upgrading or replacing existing treatment facilities. Environmental Restoration activities are projects which assess and clean up inactive waste sites. These include two inactive landfills, three French Drains, two inactive wastewater treatment facilities and a number of areas that may have been contaminated with small amounts of hazardous chemicals. A number of D\&D projects for on-site nuclear facilities have been identified including clean up at the EBWR and CP-5 research reactors. The majority of the Waste Management projects involve improvements to existing treatment or storage facilities.

In 1990, ANL was the subject of a Tiger Team assessment. The team composed of approximately 60 individuals visited the site from September 17, 1990 through October 19, 1990. The environmental subteam identified 84 findings related to areas such as air, surface water, waste management, radiation, inactive waste sites, environmental management, and quality assurance. The findings represented potential noncompliance with environmental regulations and non-attainment of acceptable best management practices. However, none of the deficiencies represent a risk to the public health or the environment. In preparation for the Tiger Team, ANL conducted an internal appraisal and generated a self assessment report which contained 239 findings related to environmental protection. To resolve the deficiencies identified by the Tiger Team and the self assessment, an Action Plan was developed to address all the concerns raised by these appraisals. An internal tracking system is being developed to ensure that the various 
commitments contained in the Action Plan are satisfied and the milestones are met.

\section{Environmental Surveillance Program}

Airborne emissions of gaseous radioactive materials from ANL were monitored and the effective dose equivalents were estimated at the site perimeter and to the maximally-exposed member of the public. The CAP- 88 version of the EPA/AIRDOSE-RADRISK code was used. The estimated maximum perimeter dose was $1.2 \mathrm{mrem} / \mathrm{y}$ in the north direction, while the estimated maximum dose to a member of the public was $0.34 \mathrm{mrem} / \mathrm{y}$. This is $0.34 \%$ of the DOE radiation protection standard of $100 \mathrm{mrem} / \mathrm{y}$ for all pathways. Approximately $98 \%$ of this estimated dose is due to the release of 2606 curies of radon-220 in 1990. If the radon-220 impact is excluded from reporting, as required in $40 \mathrm{CFR} 61$, Subpart $H$, the estimated dose to the maximally-exposed individual would be $0.0091 \mathrm{mrem} / \mathrm{y}$. The estimated population dose from all releases to the approximately eight million people living within 50 miles of the site was 15.1 man-rem.

Air monitoring was also conducted at ANL for total alpha activity, total beta activity, hydrogen-3, strontium-90, isotopic thorium, isotopic uranium, and plutonium-239. No statistically significant difference was identified between samples collected at the ANL perimeter and samples collected off the site. Monitoring for chemically hazardous constituents in ambient air was not conducted.

The only source of radionuclides and chemical pollutants in surface water due to ANL releases was in Sawmill Creek below the waste water discharge point. At various times, measurable levels of hydrogen-3, strontium90, cesium-137, neptunium-237, plutonium-239, and americium-241 were detected. Of these radionuclides, the maximum annual release was 0.35 curies of hydrogen-3. The dose to a hypothetical individual using water from Sawmill Creek as his sole source of drinking water would be $0.12 \mathrm{mrem} / \mathrm{y}$. However, no one uses this as drinking water and dilution by the Des Plaines River reduces the concentrations of the measured radionuclides to levels 
below their respective detection 1 imits downstream from ANL at Lemont. Sawmili Creek is also monitored for nonradiological constituents to demonstrate compliance with State of Illinots water quality standards.

Surface soil and grass samples were collected at ten perimeter and ten off-site locations during 1990. The purpose of the sampling was to detect the possible buildup of radionuclides from the deposition of airborne emis sions. The results indicate no statistically significant difference between the perimeter and off-site concentrations of potassium-40, cesium-137, radium-226, thorium-228, thorium-232, plutonium-238, plutonium-239, and americium-241.

Sediment samples were collected from Sawmill creek, above, at, and below the point of waste water discharge. For comparison purposes, samples were also collected from the beds of ten off-site streams and ponds. The analysis of the off-site samples for selected radionuclides established their current ambient levels. Elevated levels of cobalt-60 (up to $1 \mathrm{pCi} / \mathrm{g}$ ), cesium-137 (up to $2.8 \mathrm{pCi} / \mathrm{g}$ ), plutonium-238 (up to $0.01 \mathrm{pCi} / \mathrm{g}$ ), plutonium239 (up to $0.15 \mathrm{pCi} / \mathrm{g}$ ), and americium-241 (up to $0.10 \mathrm{pCi} / \mathrm{g}$ ) were found in the sediment below the outfall and are attributed to past ANL releases.

Milk was collected from a local dairy farm unt 11 April and analyzed for hydrogen-3 and strontium-90. No radioactivity from ANL operations was detected in the milk. The milk sampling program was terminated after April 1990 when the farm was sold and the cows relocated. No other milk cows were found in the ANL vicinity.

Dose rates from penetrating radiation (gamma-rays) were measured at 14 perimeter and on-site locations, and at five off-site locations in 1990 using thermoluminescent dosimeters. The off-site results averaged $83 \pm 2$ $\mathrm{mrem} / \mathrm{y}$, consistent with the long-term average. Above-background doses occurred at two perimeter locations and were due to ANL operations. On the north side of the site, a net dose of $13 \mathrm{mrem} / \mathrm{y}$ was due to the use of a cobalt-60 irradiation source in Building 202. At the south fence, radiation from a temporary storage facility for radioactive waste resulted in an 
average net dose of $82 \mathrm{mrem} / \mathrm{y}$ for 1990. This perimeter dose was higher earlier in the year until ANL was able to ship an accumulation of transuranic (TRU) waste to INEL in the fall of 1990. The end-of-the-year perimeter fence dose was only slightly above the off-site dose rate. The estimated dose from penetrating radiation to the nearest resident south of the site was $<0.03 \mathrm{mrem} / \mathrm{y}$ and the dose to the nearest resident north of the site was $0.07 \mathrm{mrem} / \mathrm{y}$.

The potential radiation doses to members of the public from ANL operations during 1990 were estimated by combining the exposure from inhalation, ingestion, and direct radiation pathways. The pathways that dominate are the airborne releases and the cobalt-60 direct radiation dose. The highest estimated dose was about $0.41 \mathrm{mrem} / \mathrm{y}$ to individuals 1 iving $500 \mathrm{~m}$ north of the site if they were outdoors at that location during the entire year. Doses from other pathways were calculated and were small at this location. The magnitude of the doses from ANL operations are well within all applicable standards and are insignificant when compared to doses received by the public from natural radiation $(-300 \mathrm{mrem} / \mathrm{y})$ or other sources, e.g., medical $x$-rays and consumer products $(-60 \mathrm{mrem} / \mathrm{y})$.

Radiological and chemical constituents in the groundwater were monitored in several areas of the ANL site in 1990. The ANL domestic water supply is monitored by collecting quarterly samples from the four wells. A11 results were less than the limits established by the Safe Drinking Water Act except for elevated levels of TDS and turbidity.

Thirteen monitoring wells screened in the glacial till and two into the dolomite were sampled quarterly at the 317/319 Area and analyzed for radiological and volatile organic constituents. The major organic contaminants detected were perchloroethene, trichloroethene, 1,1-dichloroethane, 1,1,1trichloroethane, cis-1,2-dichloroethene, carbon tetrachloride, and chloroform. Measurable levels of hydrogen-3, strontium-90, and cesium-137 were present in several of the wells. A characterization program statement of work has been prepared to assess the extent of the groundwater contamination. 
Thirteen monitoring wells screened in the glacial till and two into the dolomite at the 800 Area sanitary landfill are sampled on a quarterly basis and analyzed for metals, volatile organic compounds, and hydrogen-3. Elevated levels of iron, manganese, $\mathrm{pH}$, arsenic, and hydrogen-3 were found in some wells. Significant levels of hydrogen-3, acetone, and other ketones were found in one of the dolomite wells. A work plan for a groundwater characterization program at this site is currently undergoing regulatory review.

An extensive quality assurance program is maintained to cover all aspects of the environmental surveillance sampling and analysis programs. Approved documents are in place along with the supporting standard operating procedures. Newly collected data were compared both with recent results and historical data to ensure that deviations from previous conditions were identified and promptly evaluated. Samples at all locations were collected using well-established and documented procedures to ensure consistency. Samples were analyzed by documented standard analytical procedures. Data quality was verified by a continuing program of analytical laboratory quality control, participation in inter-laboratory cross-checks, and replicate sampling and analysis. Data were managed and tracked by a dedicated computerized data management system which assigns unique sample numbers, schedules collection and analysis, checks status, and prepares tables and information for the annual report. 


\section{INTRODUCTION}

\subsection{General}

This annual report on the Argonne National Laboratory-East (ANL) environmental protection program provides the U. S. Department of Energy (DOE), environmental agencies, and the public with information on the levels of radioactive and chemical pollutants in the vicinity of ANL and on the amounts, if any, added to the environment by ANL operations. It also summarizes ANL's compliance with applicable environmental laws and regulations and highlights significant accomplishments and problems related to environmental protection. The report follows the guidelines given in DOE order $5400.1 .^{1}$

Argonne conducts a continuing program of environmental surveillance on and near the site to determine the identity, magnitude, and origin of radioactive and chemical substances in the environment. The detection of any such materials released to the environment by ANL is of special interest. One important function of the program is to verify the adequacy of ANL's pollution controls.

Argonne is a DOE energy research and development laboratory with several principal objectives. It conducts a broad program of research in the basic energy and related sciences (physical, chemical, material, computer, nuclear, biomedical, and environmental) and serves as an important engineering center for the study of nuclear and nonnuclear energy sources. Energy-related research projects conducted during 1990 included: advanced reactor development; safety studies for light water and breeder reactors; component and material development for fission and fusion reactors; superconductivity advances and applications; improvements in the use of coal for power production (particularly high-sulfur coal); synchrotron radiation accelerator design; development of electrochemical energy sources, including fuel cells and batteries for vehicles and for energy storage; and evaluation of heat exchangers for the recovery of waste heat from engines. 
Other areas of research are the use of superconducting magnets for improved nuclear particle accelerators, fundamental coal chemistry studies, the immobilization of radioactive waste products for safe disposal, medical radioisotope technology, carcinogenesis, and the biological effects of small amounts of radiation. Environmental research studies include biological activity of energy-related mutagens and carcinogens; characterization and monitoring of energy-related pollutants; and the effects of acid rain on vegetation, soil, and surface water quality. A significant number of these laboratory studies require the controlled use of radioactive and chemicaliy toxic substances.

The principal nuclear facilities at ANL are: a $185 \mathrm{~kW}$ light-water cooled and moderated biological research reactor (JANUS), fueled with enriched uranium; a superconducting heavy ion linear accelerator (Argonne Tandem Linac Accelerating Systeni, ATLAS); a $22 \mathrm{MeV}$ pulsed electron Linac; a 60-in cyclctron; several other charged particle accelerators (principally of the Van de Graaff and Dynamitron types); a large fast neutron source (Intense Pulsed Neutron Source, IPNS) in which high-energy protons strike a uranium target to produce neutrons; cobalt-60 irradiation sources; chemical and metallurgical plutonium laboratories; and several hot cells and laboratories designed for work with multi-curie quantities of the actinide elements and with irradiated reactor fuel materials. The DOE New Brunswick Laboratory, a safeguards plutonium and uranium measurements and analytical chemistry laboratory, is located on the ANL site.

Two activities initiated in 1984 and continued in 1990 have some potential environmental impact: (1) management of radioactive contamination remaining from the proof-of-breeding in light-water reactors project, which involved the dissolution and analysis of irradiated thorium and uranium-233 dioxide fuel elements and (2) recovery of tritium from reactor irradiated ceramic lithium compounds. The shut down 5-MW heavy water enriched uranium research reactor (CP-5) and the EBWR are in various states of decontamination and decommissioning.

The principal nonnuclear activities at ANL in 1990 that may have measurable impacts on the environment include the use of a coal-fired boiler 
(No. 5), studies of the closed-loop heat exchanger for waste heat recovery, disposal of waste in the on-site sanitary landfill, disposal of water treatment chemicals, and use of large quantities of chlorine for water treatment. The boiler, designed to burn high-sulfur (3.5\%) 111 inois coal to produce steam for ANL use, is equipped with a slaked lime spray scrubber and bag collector to reduce sulfur dioxide and particulate emissions. The closed-10op heat exchanger studies involved the use of moderately large quantities of toxic or flammable organic compounds, such as toluene, Freon, biphenyl oxides, methyl pyridine, and trifluoroethanol. The landfill consists of an unlined area used for disposal of most of the solid, non-hazardous waste generated on-site. The treatment of the ANL drinking water results in the release of large quantities of TDS and chloride to Sawmill creek. Chlorine usage for waste water treatment was without incident. The major potential for environmental impact from these materials would be associated with any accidental releases caused by equipment malfunction. However, no such releases have occurred.

\subsection{Description of Site}

Argonne National Laboratory (Illinois site) occupies the central 688 hectares $(1,700$ acres) of a 1,514-hectare $(3,740$-acre) tract in DuPage County. The site is $43 \mathrm{~km}(27 \mathrm{mi})$ southwest of downtown Chicago and $39 \mathrm{~km}$ (24 mi) west of Lake Michigan. It is north of the Des Plaines River valley, south of Interstate Highway 55 (I-55) and west of 111 inois Highway 83. Figures 1.1 and 1.2 are maps of the site, the surrounding area, and sampling locations of the monitoring program. The 826-hectare (2,040-acre) Waterfall Glen Forest Preserve surrounding the site is former ANL property that was deeded to the DuPage County Forest Preserve District in 1973 for use as a public recreational area, nature preserve, and demonstration forest. Figure 1.1 contains numbers on the abscissa and letters on the ordinate. In this report, facilities are identified by the alpha-numeric designations in Figure 1.1 to facilitate their location.

The terrain of ANL is gently rolling, partially wooded, former prairie and farmland. The grounds contain a number of small ponds and streams. The principal stream is Sawmill creek, which runs through the site in a 


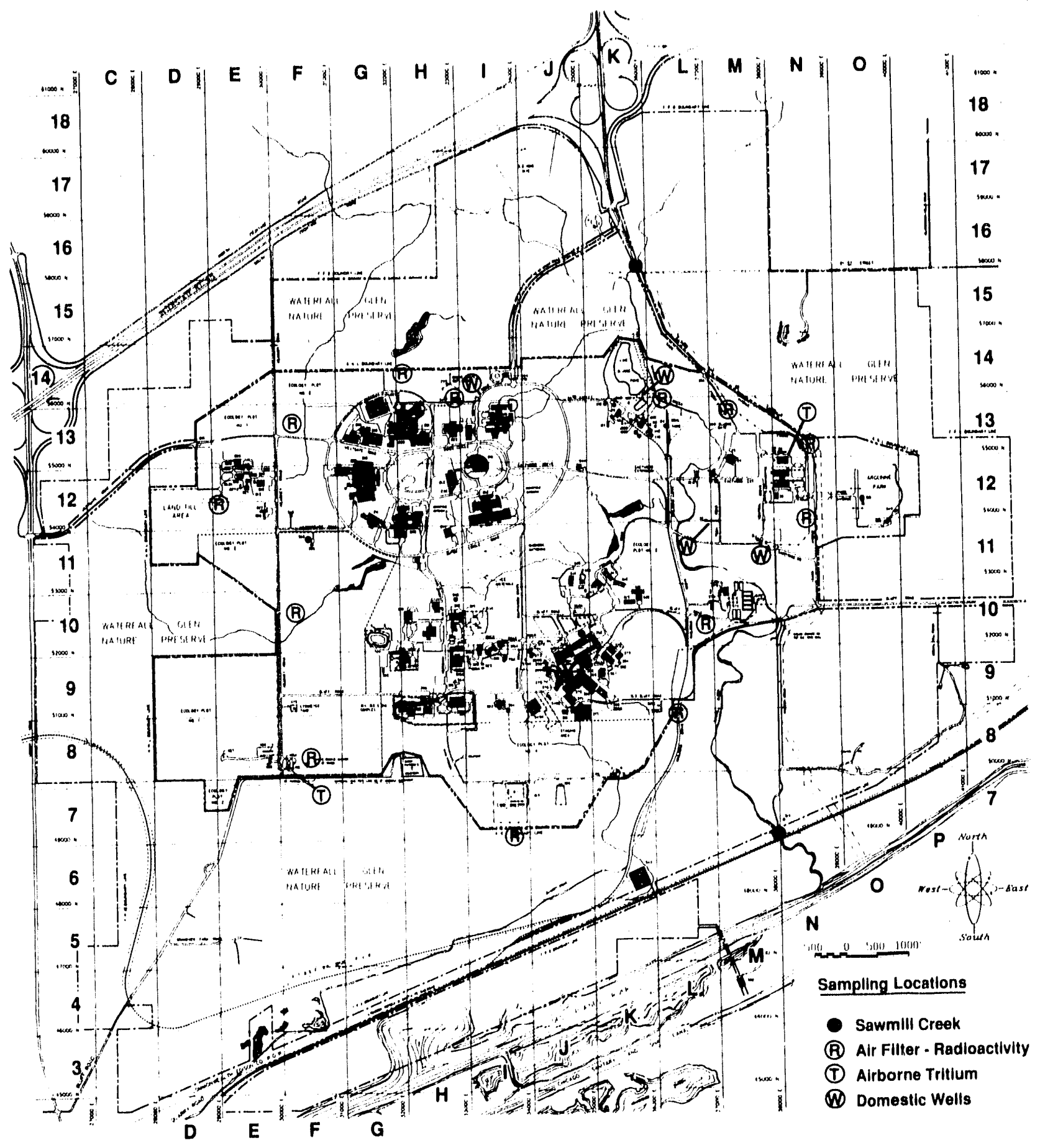

Figure 1.1 Sampling Locations at Argonne National Laboratory 


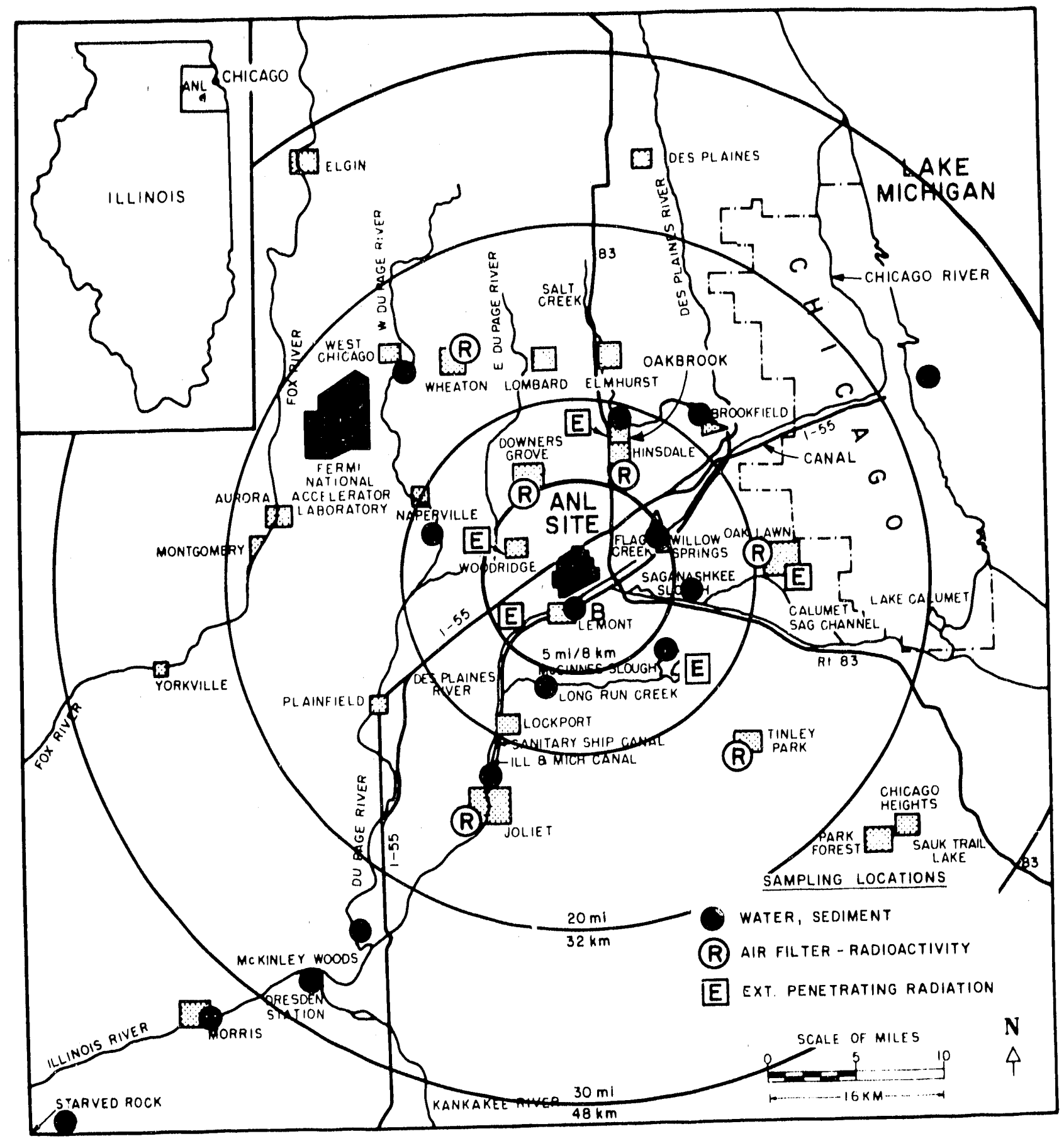

Figure 1.2 Sampling Locations Near Argonne National Laboratory 
southerly direction and enters the Des Plaines River about $2.1 \mathrm{~km}(1.3 \mathrm{mi})$ southeast of the center of the site. The land is drained primarily by Sawmill creek, although the extreme southern portion drains directly into the Des Plaines River, which flows along the southern boundary of the forest preserve. This river flows southwest until it joins the Kankakee River about $48 \mathrm{~km}$ (30 $\mathrm{mi})$ southwest of ANL to form the Illinois River.

The largest topographical feature of the area is the Des Plaines River channel, which is about $1.6 \mathrm{~km}$ (1 $\mathrm{mi}$ ) wide. This channel contains the river, the Chicago Sanitary and Ship Canal, and the Illinois and Michigan Canal. Their presence extends the uninhabited area created by the ANL site and surrounding forest preserve about $1.6 \mathrm{~km}$ (1 $\mathrm{mi}$ ) south of the site. The elevation of the channel surface is $180 \mathrm{~m}(578 \mathrm{ft}$ ) above sea level. The bluffs that form the southern border of the site rise from the river channel at slope angles of $15^{\circ}$ to $60^{\circ}$, reaching an average elevation of $200 \mathrm{~m}$ $(650 \mathrm{ft})$ above sea level at the top. The land then slopes gradually upward reaching the average site elevation of $220 \mathrm{~m}(725 \mathrm{ft})$ above sea level at $915 \mathrm{~m}(3,000 \mathrm{ft})$ from the bluffs. Several large ravines oriented in a north-south direction are located in the southern portion of the site. The bluffs and ravines generally are forested with mature deciduous trees. The remaining portion of the site changes in elevation by no more than $7.6 \mathrm{~m}$ $(25 \mathrm{ft})$ in a horizontal distance of $150 \mathrm{~m}(500 \mathrm{ft})$. The Chicago District Pipe Line Co. and the Atchison, Topeka, and Santa Fe Railroad have rightsof-way in the southern portion of the forest preserve, Additional information about the site is given in the 1982 draft Argonne Environmental Assessment. ${ }^{2}$

\subsection{Population}

The area around ANL has experienced a large population growth in the past 30 years. Large areas of farmland have been converted into housing. Table 1.1 presents directional and annular 80-km (50-mi) population distribution for the area, which is used for the population dose calculations later in this report. The population distribution, centered on the CP-5 reactor (Location 9G in Figure 1.1), was prepared by the Geographic Data Systems Computing and Telecommunications Division at Oak Ridge National 


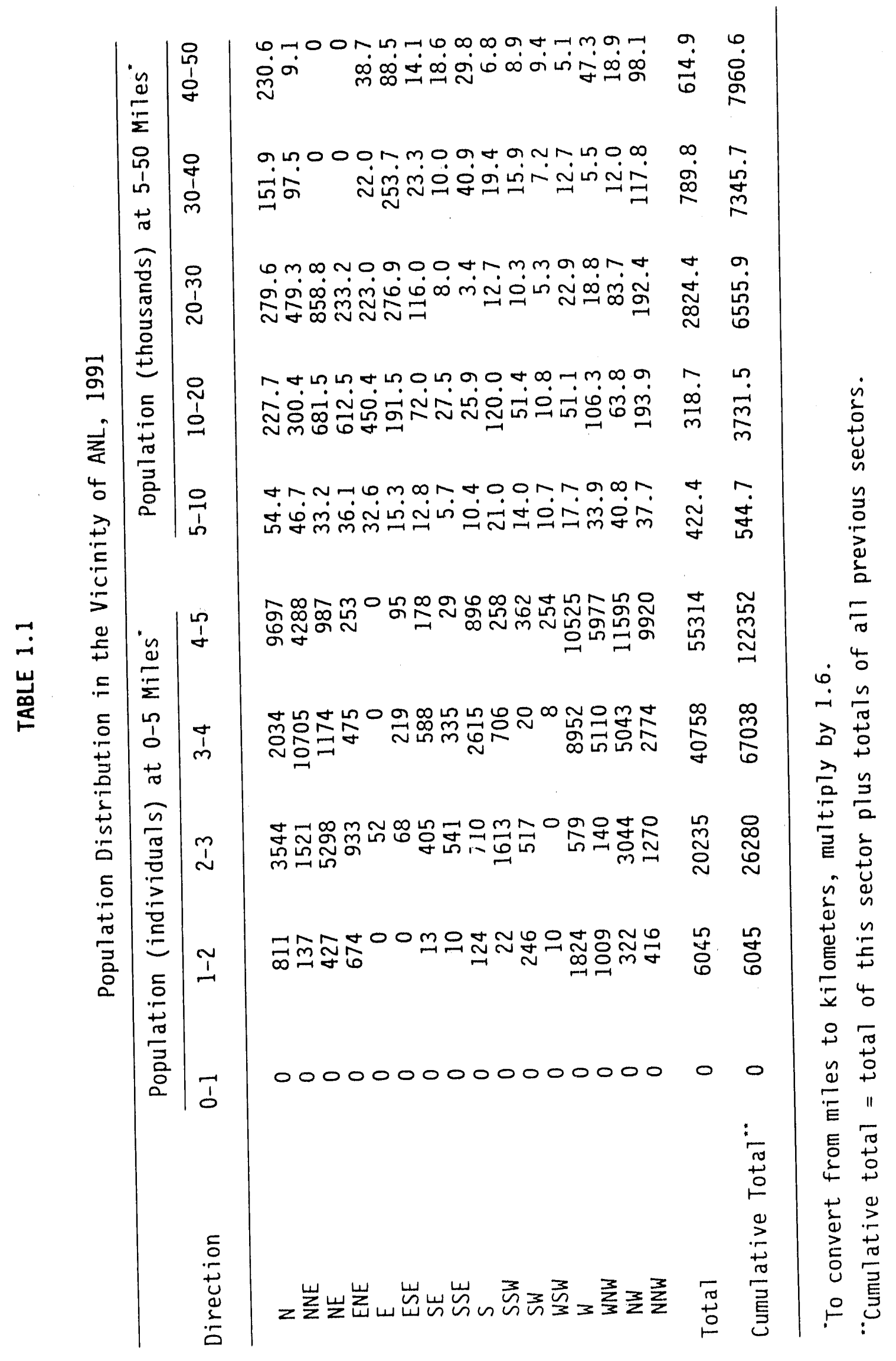


Laboratory and represents projections to 1991 based on the 1980 census data. The populations for distances within $8 \mathrm{~km}(5 \mathrm{mi})$ of the site were modifled by using quarter-section population data supplied by the Northeastern Illinois Planning Commisston, as adjusted on the basts of local observa. tions. The 1990 census data is not yet available.

\subsection{Climatology}

The climate of the area is representative of the upper Mississippi Valley, as moderated by Lake Michigan. Summartes of the meteorological data collected on the site from 1949 to 1964 are available ${ }^{3}$ and provide a histortcal sample of the climatic conditions. The most important meteorological parameters for the purposes of this report are wind direction, wind speed, temperature, and precipitation. The wind data are used to select air sampling locations and distances from sources and to calculate radiation doses from air emissions. Temperature and precipitation data are useful in interpreting some of the monitoring results. The 1990 data were obtained from the on-site ANL meteorological station. The 1990 average monthly and annual wind roses are shown in Figure 1.3. The wind roses are polar coordinate plots in which the lengths of the radii represent the percentage frequency of wind speeds in classes of $2.01-6 \mathrm{~m} / \mathrm{s}(4.5-13.4 \mathrm{mph}), 6.01-10 \mathrm{~m} / \mathrm{s}$ (13.4-22.4 $\mathrm{mph})$, and greater than $10.01 \mathrm{~m} / \mathrm{s}(22.4 \mathrm{mph})$. The number in the center of each wind rose represents the percentage of observations of wind speed less than $2 \mathrm{~m} / \mathrm{s}(4.5 \mathrm{mph})$ in all directions. The direction of the radii from the center represents the direction from which the wind blows. Sixteen radii are shown on each plot at $22.5^{\circ}$ intervals; each radius represents the average wind speed for the direction covering $11.25^{\circ}$ on either side of the radius.

The monthly wind roses indicate that the winds are variable, so that monitoring for airborne releases must be carried out in all directions from the site. For example, the dominant wind direction in January and February was from the south, while in July it is north-northeast. The annual average wind rose for 1990 is consistent with the long-term average wind direction, which usually varies from the west to south, but with a significant northeast component. Precipitation and temperature data for 1990 are shown in 

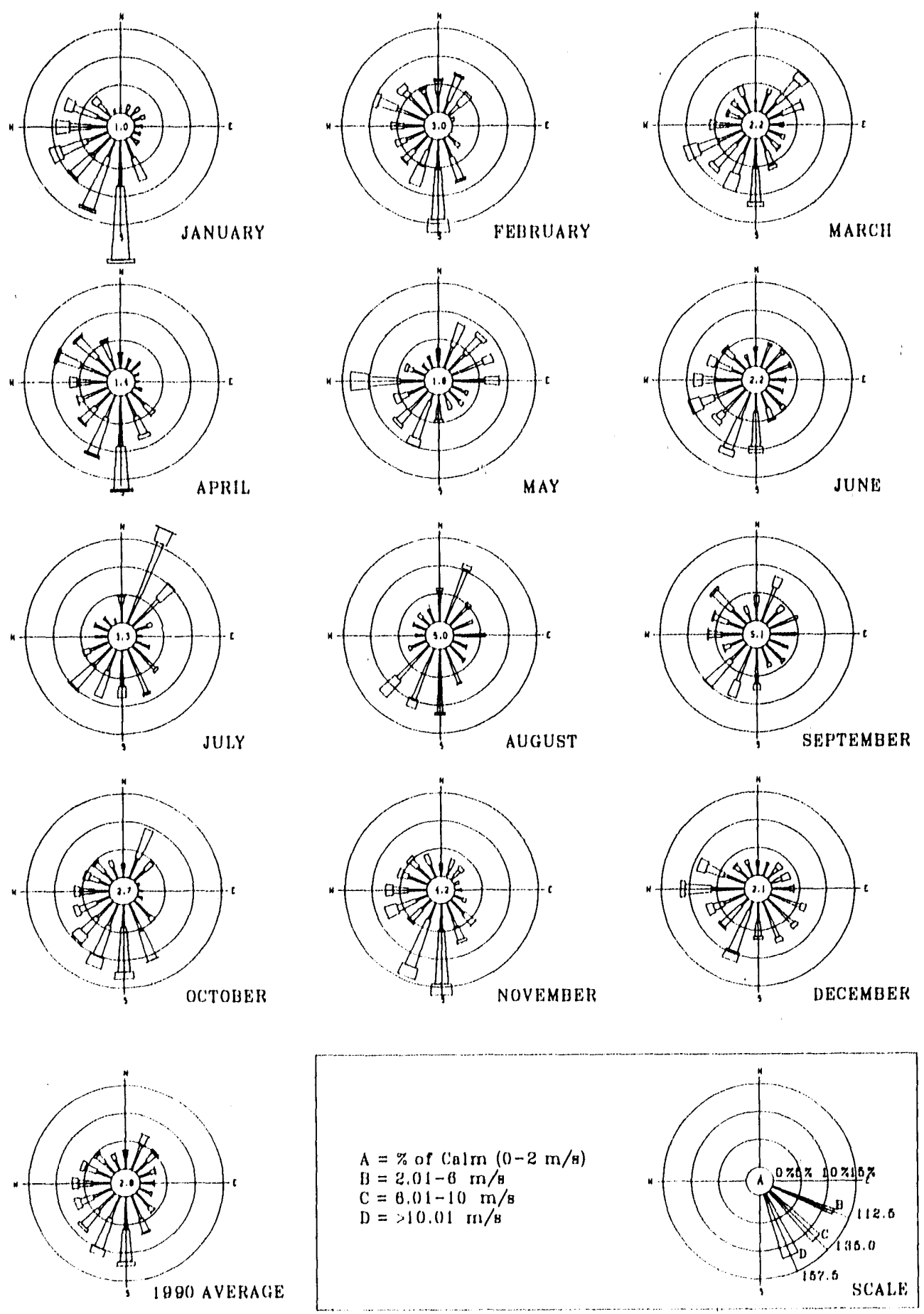

Figure 1.3 Monthiy and Annual Wind Roses at Argonne National Laboratory, 
Table 1.2. The monthly prectpitation data for 1990 showed marked differences from the average. For example, May, June, July, and November were above the average, while the other months were simflar to the average. The annual total was almost $50 \%$ higher than the long-term average. Except for the first three months being warmer than normal, the temperatures were similar to the long-term averages.

\subsection{Geohydrology}

The geology of the ANL area consists of about $30 \mathrm{~m}(100 \mathrm{ft})$ of glacial till overlying dolomite bedrock of Niagaran and Alexandrian dolomite from the Silurian age. Maquoketa shale of the Ordovictan age and older dolomites and sandstones of Ordovician and Cambrian ages underlie these formations. The beds are nearly horizontal.

Two principal aquifers are used as water supplies in the vicinity of ANL. The upper aquifer is the Niagaran and Alexandrian dolomite, which is about $60 \mathrm{~m}(200 \mathrm{ft})$ thick in the ANL area and has a plezometric surface between 15 and $30 \mathrm{~m}$ ( 50 and $100 \mathrm{ft}$ ) below the ground surface for much of the site. The lower aquifer is Galesville sandstone, which lies between 150 and $450 \mathrm{~m}$ ( 500 and $1,500 \mathrm{ft}$ ) below the surface. Maquoketa shale separates the upper dolomite aquifer from the underlying sandstone aquifer. This shale retards hydraulic connection between the two aquifers.

The four domestic water supply wells now in use on the ANL site (see Figure 1.1) are drilled about $90 \mathrm{~m}(300 \mathrm{ft}$ ) deep terminating in the Niagaran dolomite. A well drilled in the Galesville sandstone $490 \mathrm{~m}(1,600 \mathrm{ft})$ deep has been taken out of service. The water level in the Niagaran dolomite has remained reasonably stable under ANL pumping, dropping about $3.7 \mathrm{~m}(12 \mathrm{ft})$ between 1960 and 1980. The aquifer appears to be adequate for future ANL. use, but this ground water source is used throughout the area. Several wells and small capacity water wells used for laboratory experiments, fire protection, and sanitary facilities also exist on the site. 


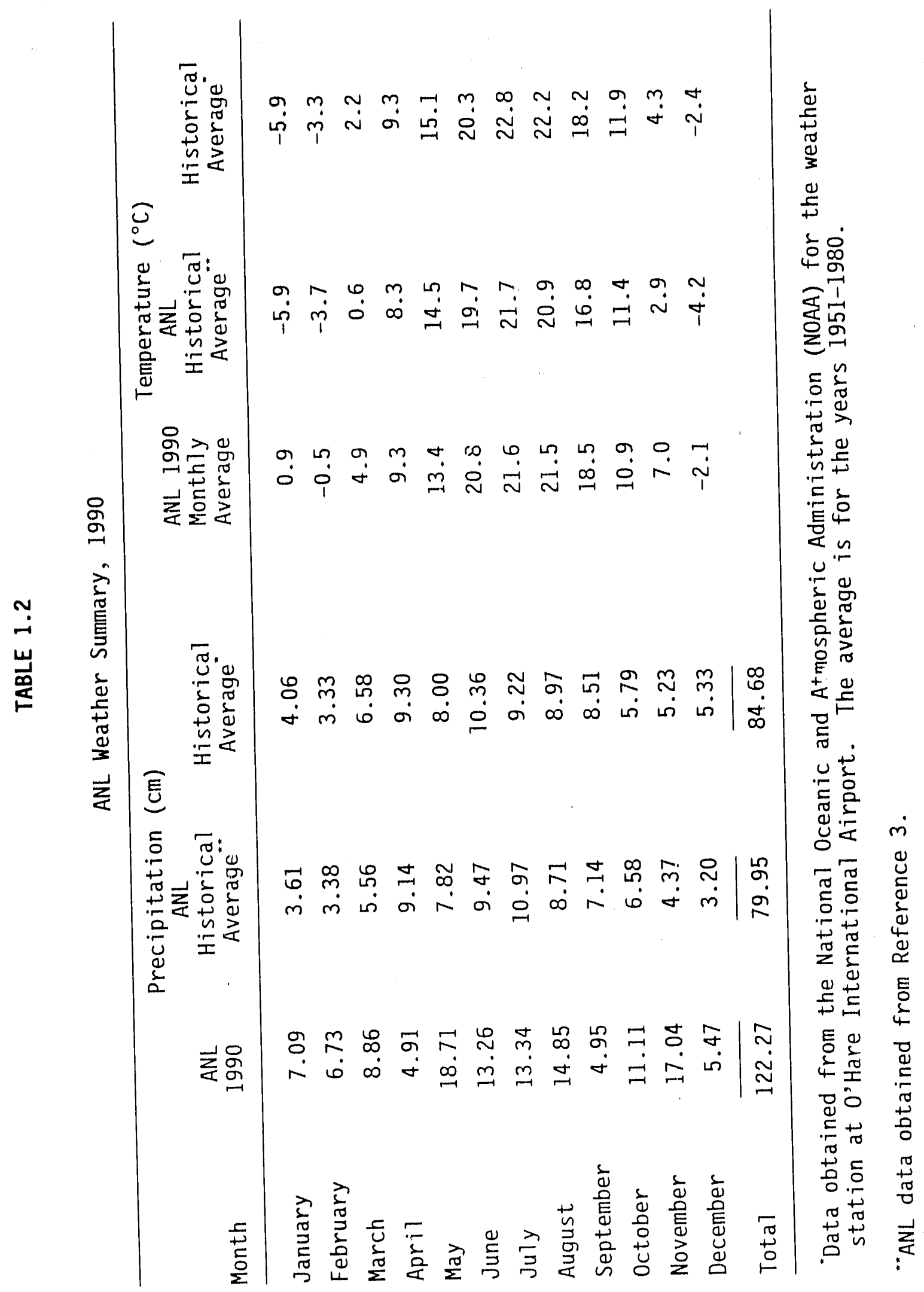




\subsection{Water and Land Use}

The principal stream that drains the ANL site is Sawmill creek. It carried effluent water continuously from a sewage treatment plant (Marion Brook Treatment Plant) located a few kllometers north of the site until October 27, 1986, when the plant was closed. Residenttal and commercial development in the area has resulted in the collection and channeling of runoff water into Sawmil1 creek. Treated sanitary and laboratory wastewater from ANL are combined and discharged into Sawmill creek at location $7 M$ in Figure 1.1. This effluent averaged 3.9 mitlion 1 iters $(1.03$ million gallons) per day. The combined ANL effluent consisted of $45 \%$ laboratory wastewater and $55 \%$ sanitary wastewater but there were wide vartations in both. The water flow in Sawmil1 creek upstream of the wastewater outfall averaged about 25 million 1 tters (6.7 million gallons) per day during 1990 .

Sawmill Creek and the Des Platnes River above Joliet, about $21 \mathrm{~km}$ $(13 \mathrm{mi})$ southwest of ANL, recetve very little recreational or industrial use. A few people fish in these waters downstream of ANL and some duck hunting takes place on the Des Plaines River. Water from the Chicago Sanitary and Ship Canal is used by ANL for cooling towers and by others for industrial purposes, such as hydroelectric generators and condensers, and for irrigation at the state prison near Joliet. The ANL usage is about 0.4 million liters $(100,000$ gallons) per day. The canal, which receives Chicago Metropolitan Sanitary District effluent water, is used for industrial transportation and some recreational boating. Near Joliet, the river and canal combine into one waterway, which continues until it joins the Kankakee River to form the Illinois River about $48 \mathrm{~km}(30 \mathrm{ml})$ southwest of ANL. The Dresden Nuclear Power Station complex is located at the confluence of the Kankakee, Des Plaines, and Illinois rivers. This station uses water from the Kankakee River for cooling and diccharges the water into the Illinois River. The first downstream location where water is used for drinking is at Alton, on the Mississippi River about $710 \mathrm{~km}(370 \mathrm{mi})$ downstream from ANL. At that location, water is used indirectly to replenish groundwater supplies by infiltration. In the vicinity of ANL, only subsurface water (from both shallow and deep aquifers) and Lake Michigan water are used for drinking purposes. 
The princtpal recreattonal area near ANL is Waterfall Glen Forest Preserve, whtch surrounds the stte (see Section 1.2 and Figure 1.1). The area ts used for hiking, skiting, and equestrian sports. Sawmill creek flows south through the eastern portion of the preserve on its way to the Des Plaines River. Several large forest preserves of the Cook county Forest Preserve District are located east and southeasit of ANL and the Des Platnes River. The preserves include the McGinnts and Sayanashkee sloughs (shown in Figure 1.2), as well as other, smaller lakes. These areas are used for picnicking, boating, fishing, and hiking. A small park located in the eastern portion of the ANL site (Location 12-0 in Figure 1.1) is for the use of ANL and DOE employees only. 


\section{COMPLIANCE SUMMARY}

Argonne National Laboratory-East (ANL) is a government owned, contractor operated (GOCO) non-production facility which is subject to environmental regulations administered by the U. S. Environmental Protection Agency (EPA) and the II? inois Environmental Protection Agency (IEPA) as well as numerous DOE Orders and Executive Orders. A detailed listing of applicable regulations is contained in DOE Order 5400.1, which establishes DOE's policy concerning environmental compliance. The status of ANL with regard to these reguiaiions and orders during 1990 is discussed in this Chapter. This chapter is divided into two parts, the 1990 whole year summary and the first quarter, 1991 summary. The latter section discusses important developments which occurred during the early part of 1991.

To insure compliance with both the letter and spirit of these regulations, ANL has made a commitment to comply with all applicable environmental regulations as described in the following policy statement revised during 1990.

"It is the policy of Argonne National Laboratory that its activiiies will be conducted in such a manner that worker and public safety, including protection of the environment, is given the highest priority. The Laboratory will comply with all applicable Federal and State environmental laws, regulations and orders."

\subsection{Clean Air Act}

The Clean Air Act (CAA) is a Federal statute that specifies ambient air quality standards, sets emission limits for air pollutants and determines emission limits and operating criteria for a number of hazardous air pollutants. The program is implemented by individual states through the a state Implementation Plan (SIP), which describes how that state will ensure compliance with the air quality standards. A number of major changes to the Clean Air Act were made with the passage of the Clean Air Act Amendments of igsô. Hust of these changes wi!? haye ?itt.le or no impact on ANL. However, 
some changes, such as amendments to the hazardous pollutants regulations which expand the number of hazardous air pollutants from eight to 189, could have significant impact in the future.

The primary tool for enforcing most provisions of the CAA for point source emissions is the permitting process. The IEPA requires that all point sources of air emissions, except for those specifically excluded, apply for either a construction permit (for proposed new sources) or operating permit (for existing or newly constructed sources). The permit, when issued, contains specific requirements necessary to ensure that the point source operates within the limits of the permit.

The ANL site contains a large number of air emission point sources. The vast majority are laboratory ventilation systems which are exempt from state permitting requirements, except for those systems emitting radionuclides. During 1990 a search for unpermitted emission points was conducted throughout the Laboratory. By the end of 1990, approximately 35 emission points subject to permitting requirements had been identified. By the end of 1990, a total of twelve air permits were in place. Permit applications were submitted or were being prepared for the remainder. Section 2.15 contains a listing of the permits in effect at ANL.

\subsubsection{National Emission Standards for Hazardous Air Pollutants}

The National Emission Standards for Hazardous Air Pollutants (NESHAP) are a body of federal regulations that set forth emission limits and other requirements, such as monitoring, record keeping, and operational requirements, for activities generating emissions of certain hazardous air pollutants. The standards for asbestos and radionuclides are the only standards affecting ANL operations.

\subsubsection{Asbestos Emissions}

Many buildings on the ANL site contain large amounts of asbestos-containing materials (ACM) such as insulation around pipes and tanks, fire proofing and numerous other applications. This material is removed as 
necessary during renovations or repair of equipment and facilities. The removal and disposal of this material is governed by the asbestos NESHAP.

The standards for asbestos specify detailed requirements for removal and disposal of certain types of ACM. Until the November 1990 revisions, only friable (easily crushed) ACM was regulated. Now, however, many other types of $A C M$ are regulated, including non-friable materials which have been, or could be reduced to a crumbly, pulverized or powder state through the process of removal or disposal. This change greatly increases the amount of material regulated by the NESHAP.

The standard describes accepted procedures for removal of ACM, including notification of the IEPA prior to removal of greater than certain amounts, work practices and procedures to be used and emission control procedures to be used. The use of specially trained individuals for removal of ACM is mandated.

ANL maintains an asbestos abatement program designed to assure compliance with these and other regulatory requirements. The removal of ACM at the Laboratory is done either by a specially trained Waste Management Operations (WMO) crew (used for small, short lead time jobs such as piping repairs) or by outside contractors specializing in ACM removal work (for large building renovation or major piping removal projects). All removal work is done in strict compliance with both the NESHAP requirements as well as the OSHA requirements governing worker safety at $A C M$ removal sites. When $A C M$ is encountered during a renovation or demolition project, it is carefully wetted or otherwise encapsulated and completely removed. The work area is sealed off using disposable glove bags or temporary plastic sheeting barriers, and high-efficiency air filtration equipment is used to prevent emissions. Air is monitored in the vicinity of such work by ANL Industrial Hygiene personnel during the removal work and after the work is completed in order to verify that adequate precautions have been taken to prevent the release of significant amounts of asbestos.

The asbestos NESHAP standards require that the IEPA be notified before large asbestos removal projects involving more than $80 \mathrm{~m}(260 \mathrm{ft})$ of pipe 
insulation or $15 \mathrm{~m}^{2}\left(160 \mathrm{ft}^{2}\right)$ of other material are begun. During 1990 there were no removal projects which exceeded these amounts and thus no notifications were made. A total of 186 separate removal projects were completed, however, generating 65 cubic meters (2298 cubic feet) of ACM waste. These removal projects were all relatively small projects involving small amounts of piping or building material. Much of the material removed and disposed of as ACM is actualiy not regulated ACM, however, to insure consistency and to be conservative, all $A C M$ is treated as if it were regulated. The revised NESHAP requires estimation of the total amount of $A C M$ to be removed during renovation or demolition activities during each upcoming calendar year. If this amount exceeds the regulatory levels above, the IEPA must be notified. In late 1990, ANL made such a notification for activities planned for 1991; however, since this change came into effect in late 1990, it was not necessary to make such a notification for 1990.

A separate portion of the standard contains requirements for waste disposal sites used for disposal of ACM. The acceptable disposal practice involves placing wetted waste materials into labeled, leakproof plastic bags for disposal in landfills. Off-site shipments are to be accompanied by completed shipping manifests. A specially designated portion of the ANL landfill is the primary disposal site for ACM generated on-site. The principal requirements applicable to the landfill relate to covering the $A C M$ daily with at least 6 inches of non asbestos-containing materials and maintenance of disposal records. To comply with this standard, the ACM is buried before the end of the work shift, normally, immediately after it is placed in the landfill. The landfill operators maintain a record of all ACM placed in the landfill.

\subsubsection{Radionuclide Emissions}

The NESHAP standard for radionuclide emissions from DOE facilities (40 CFR 61, Subpart H) establishes the emission standards for release of radionuclides to the air and requirements for monitoring, reporting, and record keeping. This regulation was revised in late 1989, resulting in increased monitoring and reporting requirements. A number of emission points at ANL are subject to these requirements. These points include ventilation systems 
for hot cell facilities for storage and handling of radioactive materials (Buildings 200, 205, 212 and 350), ventilation systems for currently operating and inactive reactors (Building 202, JANUS reactor and Building 330 , inactive reactor $(P-5)$, ventilation systems for particle accelerators (Building 211, cyclotron and Building 375, IPNS facility), and several ventilation systems associated with the New Brunswick Laboratory. In addition, many small ventilation systems and fume hoods are occasionally used for processing of small quantities of radioactive materials. The radionuclide NESHAP requires that all air emission sources of radionuclides be evaluated to determine whether the magnitude of these emissions is above a threshold amount which would result in an effective dose equivalent to the maximally exposed individual of greater than $1 \%$ of the standard of 10 mrem/yr. Those sources with greater than this amount of emissions must be monitored in accordance with 40 CFR 61.93 (b) and a report issued annually summarizing the emissions measured. Any emission point below this threshold must be measured occasionally to verify the low rate. At ANL, the major emission sources are continuously monitored to comply with this requirement. However, to satisfy these requirements for the large number of smaller sources, all radionuclide air emission sources are being reevaluated and plans are being made to sample affected exhaust stacks. The emissions from the New Brunswick Laboratory are included with ANL emissions when calculating dose rates under NESHAP. Continuous monitors are being installed on these exhaust stacks to more accurately determine emission rates.

Routine continuous monitoring of the larger emission sources has indicated that the amount of radioactive material released to the atmosphere from these sources is extremely small, resulting in a very small incremental radiation dosage to the neighboring population. The calculated potential maximum individual off-site dose to a member of the general public for 1990 was 0.0091 mrem (excluding radon-220), which is $0.09 \%$ of the 10 mrem per year EPA standard. Section 4.7.1. contains a more detailed discussion of these emission points and compliance with the standard.

IEPA policy requires that all sources of hazardous pollutants subject to a NESHAP apply for and receive an operating permit. This provision means that ANL must classify and permit all emission points for radionuclides, 
including laboratory hoods, which are otherwise exempt. During 1990, a survey of the most significant radionuclide-using facilities was conducted to identify nonpermitted emission points. Permit applications were prepared and submitted to the IEPA for most of these points. As shown in section 2.15.1 of this chapter, many of these permits have already been issued, while a number are still being processed by the IEPA. Permits covering the large number of fume hoods are currently being prepared. To complete this task, a detailed survey of fume hood usage, as well as sampling and analysis of exhaust points will be required. This work is currently planned for late 1991.

\subsubsection{Conventional Air Pollutants}

The ANL site contains a number of sources of conventional air pollutants including a steam plant, gasoline and methanol fuel dispensing facilities, two alkali metal reaction booths, a small vapor degreaser, a number of bulk chemical tanks, a dust collection system, a medical equipment sterilization unit, and a research facility for combustion and power generation research (FEUL facility). These emission sources have either been granted operating permits by the IEPA or a permit has been applied for, as shown in Section 2.15. During 1990, a survey of the majority of the site was conducted to identify unpermitted emission sources of conventional pollutants. Operating permit applications were then prepared and submitted to the IEPA.

The vapor degreaser located in Building 363 was tested for VOC emissions during 1990 and was found to be out of compliance. The manufacturer was contacted and a modification to the system was made, bringing the unit back into compliance.

The operating permit for the steam plant requires continuous opacity and sulfur dioxide monitoring of the smoke stack from Boiler No. 5, the only one of the five boilers equipped to run on coal. The permit requires submission of a quarterly report listing any excursions beyond emission limits for this boiler [30\% opacity averaged over six minutes and 1.8 ib sulfur dioxide $\left(\mathrm{SO}_{2}\right)$ per million Btu averaged over a one-hour period]. In the last few years, the air pollution control equipment associated with Boiler No. 5 
has experienced numerous breakdowns and fallures, usually of short duration. The $\mathrm{SO}_{2}$ scrubber was designed and built as a demonstration test unit in 1980; however, it has operated in recent years as an operations unit. Many of the components have reached the end of their useful $1 \mathrm{ife}$, resulting in frequent breakdowns and malfunctions. As a result, the air emissions frequently exceed the allowable amounts. These excursions have been reported to the IEPA as required. During early 1990, ANL received a Compliance Inquiry Letter (CIL) from the IEPA and EPA regarding excessive violations of these limits. In response to this CIL, ANL prepared and submitted an operating procedure for the boiler which specifies that only natural gas or low sulfur coal will be used, once the current supply of high sulfur coal is exhausted. In April of 1990, Boiler No. 5 was shut down. Since that time, the site steam requirements have been met using the four natural gas fired bollers. While it was still operating, in early 1990, it recorded 371 violations of opacity limits and 19 violations of $\mathrm{SO}_{2}$ limits.

The fuel dispensing facilities are used to service vehicles associated with ANL only and, except for methanol vapors, have VOC emissions typical of any commercial gasoline service station. These facilities are equipped with vapor control devices and have an annual VOC emission rate of less than 200 pounds per year. During the Tiger Team assessment, discussed in Chapter 3 , it was discovered that the vehicle maintenance fuel dispensing facility air operating permit stated that a vapor recovery system was in place, when in fact, no such system was ever installed. The permit has been modified by the IEPA to reflect actual conditions.

\subsection{Clean Water Act}

The Clean Water Act (CWA) was established in 1977 as a major amendment to the Federal Water Pollution Control Act of 1972 and was substantially modified by the Water Quality Act of 1987 . The CWA provides for the restoration and maintenance of water quality in all waters throughout the country, with the ultimate goal of "fishable and swimmable" water quality. The act established the National Pollutant Discharge Elimination System (NPDES), which is the regulatory mechanism designed to achieve this goal. The authority to implement the NPDES program has been delegated to those states, 
including 111 inois, that have developed a program substant tally the same and at least as stringent as the Federal NPDES program.

The 1987 amendments to the CWA significantly changed the thrust of enforcement activities. Greater emphasis is now placed on monitoring and control of toxic constituents in wastewater, the permitting of outfalls composed entirely of stormwater, and the imposition of regulations governing sewage sludge disposal. These changes in the NPDES program resulted in much stricter discharge 1 imits and greatiy expanded the number of chemical constituents monitored in the effluent. The wastewater treatment facilities on the ANL site are being upgraded to comply with the changing requirements.

\subsubsection{Liquid Effluent Discharge Permit}

The primary tool for enforcing the requirements of the NPDES program is through the NPDES permitting process administered by the IEPA. Before wastewater can be discharged to any receiving stream, each wastewater discharge point (outfall) must be characterized and described in a permit application. The IEPA then issues a permit that contains numeric limits on certain pollutants 1 ikely to be present and defines a number of specific and general requirements, including sampiing and analysis schedules and reporting and record keeping requirements. Wastewater generation activities at ANL are covered by NPDES permit IL 00334592 (DOE is the legal permit holder for all ANL. environmental permits). This permit expires in January, 1994.

Wastewater at ANL is generated by a number of activities and consists of sanitary wastewater (from restrooms, cafeteria sinks and sinks in certain buildirigs and laboratories), laboratory wastewater (from laboratory sinks and floor drains in most bulldings), steam boller blowdown, cooling water, and cooling tower blowdown. The current permit authorizes the release of wastewater from nine separate outfalls, most of which discharge directly or indirectly into Sawmill creek. In addition, the permit requires monitoring of the wastewater at two internal sampling points that combine to form the main wastewater outfall, outfall 001 . Table 2.1 cascribed these outfalls, and the locations are shown in Figure 2.1. Two of these outfalls, 009 and 
TABLE 2.1

Description of NPDES Outfalls at ANL.

\begin{tabular}{|c|c|c|c|}
\hline $\begin{array}{l}\text { Outfal1" } \\
\text { Number }\end{array}$ & Description & Status & $\begin{array}{l}\text { Average } \\
\text { Flow } \\
\text { (Mtilion } \\
\text { Gallons/Day) }\end{array}$ \\
\hline 001 & $\begin{array}{l}\text { Combined discharge of } 001 A \\
\text { and } 001 B \text { - main site outfall } \\
(7 M)\end{array}$ & Active & $0.8-1.2$ \\
\hline $001 \mathrm{~A}$ & $\begin{array}{l}\text { Santtary wastewater treatment } \\
\text { plant effluent }\end{array}$ & $\begin{array}{l}\text { Active - internal } \\
\text { sampling point }\end{array}$ & $0.4-0.6$ \\
\hline $001 B$ & $\begin{array}{l}\text { Laboratory wastewater treatment } \\
\text { plant effluent }\end{array}$ & $\begin{array}{l}\text { Active - internal } \\
\text { sampling point }\end{array}$ & $0.4-0.6$ \\
\hline 003 & $\begin{array}{l}\text { Stormwater runoff, cooling } \\
\text { water and cooling tower blow- } \\
\text { down }\end{array}$ & Active & $0.1-0.3$ \\
\hline 004 & Cooling water, stormwater & Active & $0-0.05$ \\
\hline 005 & $\begin{array}{l}\text { Cooling water and cooling } \\
\text { tower blowdown, stormwater }\end{array}$ & Active & $0-0.2$ \\
\hline 006 & $\begin{array}{l}\text { Water treatment plant waste- } \\
\text { water, cooling tower drainage, } \\
\text { cooling water, stormwater }\end{array}$ & Active & $0-0.12$ \\
\hline 007 & Cooling water, stormwater & Active & $0-0.01$ \\
\hline 008 & Stormwater & Active & $0-0.01$ \\
\hline 009 & Lime sludge pond overflow & Emergency overflow & 0 \\
\hline 010 & Coal pile runoff overflow & Emergency overflow & 0 \\
\hline
\end{tabular}

Locations are shown in Figure 2.1. 


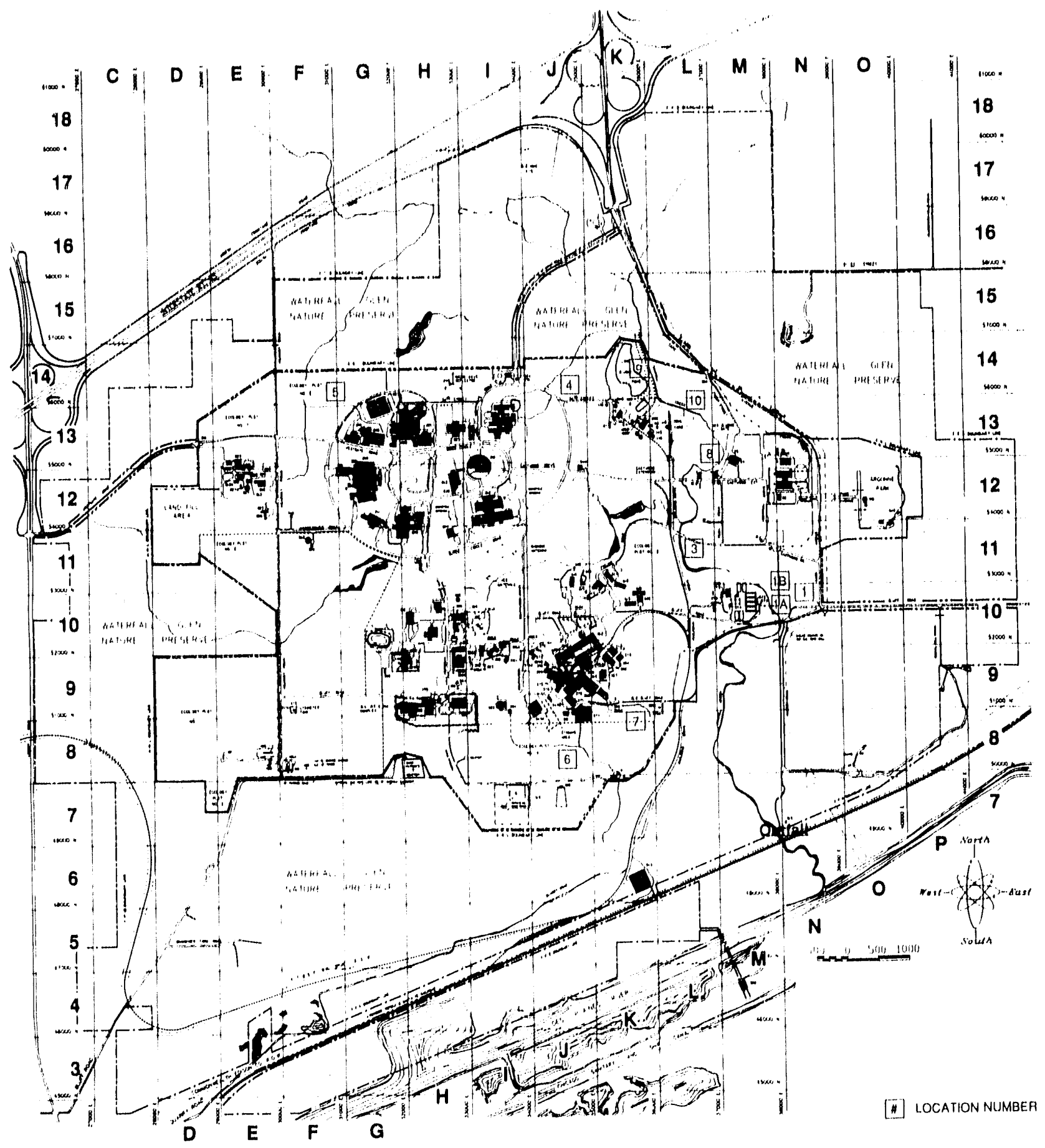

Figure 2.1 NPDES Permit Locations 
010, are used for emergency overflow discharge of wastewater only; normally there is no discharge from these points.

\subsubsection{Effluent Monitoring Results and Compliance Issues}

Results of the routine monitoring required by the NPDES permit are submitted monthly to the IEPA and quarterly to the USEPA in a Discharge Monitoring Report (DMR). As required by the permit, any noncompliance with permit limits or conditions is reported to the IEPA within 24 hours, and a written explanation of such noncompliance is submitted with each DMR. During 1990 there were 86 violations of NPDES permit limits out of approximately 1000 measurements made. This represents a $91 \%$ compliance rate, down from $93 \%$ in 1989.

The types of violations experienced were similar to recent years. A breakdown of the type of violations appears in Figure 2.2. The vast majority were violations of total dissolved solids (TDS) limits at 001 . A relatively large number of chloride violations also occurred at 001 . As a result of additional testing done on outfall 001 during August and September, as part of a study of ways to reduce TDS concentrations, there were 32 additional TDS results with values above the permitted concentrations. IEPA regulations require that any analysis beyond that called for in the permit be reported on the DMR form. As a result, there were 32 additional permit violations recorded during these two months beyond that which would have occurred if only the permit-required monitoring was conducted. The cause of these TDS and chloride violations is disposal of water softener regenerant solutions, as discussed below. The second largest category is total suspended solids (TSS) violations at a number of outfalls, primarily outfalls 003, 004 and 006 . In addition, occasional violations of pH, BOD, iron, zinc and manganese occurred. There are a number of different reasons for these excursions. Chapter 5 discusses each outfall individually and presents the suspected reasons for permit violations. 


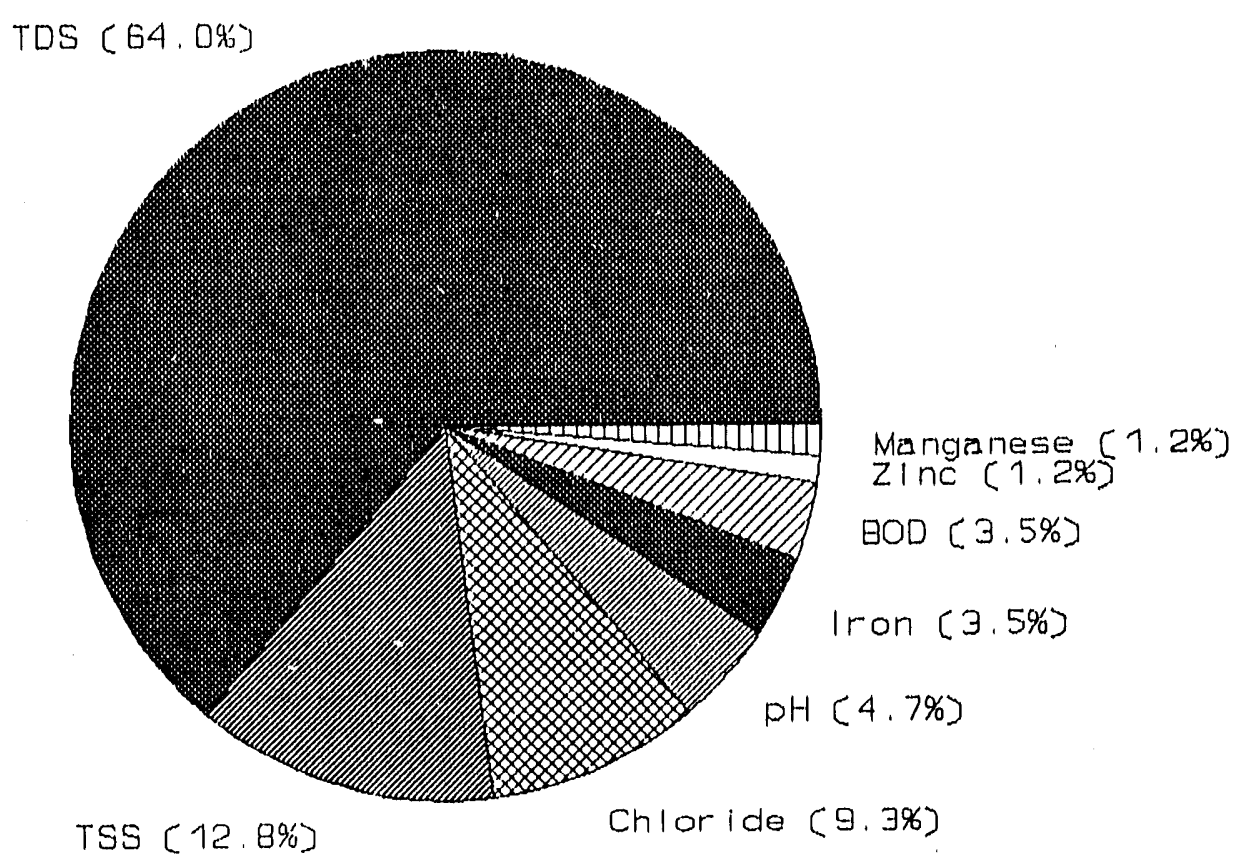

Figure 2.2 Distribution of NPDES Permit Violations, 1990

Since 1986, when a new ion-exchange water softening system was installed, ANL has experienced numerous violations of 1 imits for chlorides and total dissolved solids. These violations are the result of the disposal of water treatment system spent regenerant solutions (concentrated brine solution) into the laboratory wastewater treatment system. The laboratory wastewater treatment system was not designed to remove dissolved salts, and as a result, the salt passes directly through the system and is discharged into Sawmill creek. To prevent these violations, a treatment plant for this brine solution was proposed and a compliance date of June 30, 1990, was inserted in the permit. However, as the design of the treatment plant advanced in early 1990, it was determined that due to the nature of the salts involved, very expensive materials would be required, and even with the system in place, there was a great likel thood that the TDS limits still would not be met. As an alternative, ANL proposed installing a sewer line to the DuPage County sewer system and pumping the spent brine to the DuPage County system. The IEPA approved this proposed $p l a n$ and the design work for 
the installation of the sewer was begun. It is anticipated that by late 1991, the system should be completed and the site will come into compliance with effluent TDS and chloride limits.

The significant number of violations of TSS $1 \mathrm{imits}$ expertenced during 1990 are thought to be caused by several factors, including erosion of sot1 from construction sites and drainage ditches, the siltation of several small on-site ponds which act as settling basins to remove solids from stormwater, and the operation of two small earthen sludge holding ponds which somet imes overflow following heavy ratns, carrying solids into outfall 006. Due to the number and severity of the exceedances, the IEPA placed ANL on the EPA's list of facilities in significant noncompliance. This will result in tighter scrutiny of the discharge monitoring reports and could result in enforcement action if the violations continue. During 1991, ANL will be starting a site wide investigation of stormwater generation and erosion control to reduce these violations. Several projects are in the planning stages to reduce TSS discharges from the sludge lagoons and other sources by removal of accumulated sediments from three on-site ponds.

As a result of unusually heavy rains, wastewater flowed from outfall 010, the coal storage pile stormwiter emergency outfall, on two different occasions during 1990. Due to the composition and highiy acidic nature of the high sulfur coal stored in this area, this discharge was out of compitance with several different limits, including $\mathrm{pH}$, TSS, iron, zinc, and manganese. These two instances alone represent $13 \%$ of the total number of violations during the entire year.

To improve the level of compliance with permit limits, ANL is in the third year of an intensive effort of bullding additional wastewater treatment facilities or upgrading existing facilities. One such facility, designed to eliminate violations at outfall 010 , and to reduce violations at $001 \mathrm{~A}$ and 001 , was begun in the summer of 1990. This factlity, the boller house wastewater treatment plant, will provide physical/chemical treatment of coal pile runoff, boller house blowdown, water treatment plant wastestreams, and stormwater from the area. The design is currently being modified to resolve several deficiencies identified by the IEPA during their 
review of the NPDES construction permit for the factlity. Projects to upgrade and refurbish the laboratory and santtary wastewater treatment plants are scheduled for 1991 through 1993. These and other corrective action projects are described in the Environmental Restoration and Waste Management Five Year Plan for ANL and discussed in Chapter 3.

\subsubsection{Additional NPDES Monitoring}

The current permit requires semiannual testing of outfall 001B, the laboratory wastewater treatment plant outfa11, for all the priority pollutants (a list of 126 metals and organic compounds defined by the USEPA as being of particular concern). During 1990, this sampling was conducted in June and December. A number of volatile organic compounds were detected in these samples, at low concentration. The most significant of these is chloroform (at $23 \mu \mathrm{g} / \mathrm{L}$ ) and methylene chloride $(28 \mu \mathrm{g} / \mathrm{L}$ ) in the December sample. Barely detectable amounts (less than $5 \mu \mathrm{g} / \mathrm{L}$ ) of several other volatile organics were also found, including bromodichloromethane, dibromo-

chloromethane, toluene, 1,1,1-trichloroethane, and trichloroethene. The source of most of these materials is suspected to be from the chlorination of the water at the water treatment plant prior to its injection into the distribution system, as well as the discharge of small amounts of chemicals from various research and support operations. Mercury was detected at low concentrations $(1.5 \mu \mathrm{g} / \mathrm{L})$, as were zinc $(60 \mu \mathrm{g} / \mathrm{L})$ and barium $(230 \mu \mathrm{g} / \mathrm{L})$. Mercury has been found in the effluent frequentiy and is believed to come from numerous small scale experimental operations which utilize mercury or from residual mercury contamination in the wastewater collection system. The permit 1 imit for mercury is $3 \mu \mathrm{g} / \mathrm{L}$ for a; 30 day average value, and $6 \mu \mathrm{g} / \mathrm{L}$ for a daily maximum value. The concentrations of these metals are so low that they do not represent a significant concern. These finding are discussed further in chapter 5.

In addition to the priority pollutant analysis, the permit requires annual biological toxicity testing of the combined effluent stream, outfall 001 . This was done in July of 1990. Results of this test showed the wastewater exhibited essentially no acute toxicity; there was $100 \%$ survival of all test species in samples consisting of $100 \%$ wastewater. There was a 
slight decrease in viability of several test species at low dilutions in the chronic toxicity tests, indicating that the wastewater may exhibit some toxicity after long exposures to high concentrations.

\subsubsection{Stormwater Regulations}

In November of 1990 , the EPA promulgated new regulations governing the permitting and discharge of stormwater from industrial sites. The ANL site contains a large number of small scale operations which are considered industrial activities by the new regulation, and thus, is subject to these requirements. To satisfy the permit application information needs, an extensive stormwater characterization program will be started in mid to. late 1991. This program will measure stormwater flows and collect samples for chemical and radiological analysis. During 1991, only those outfall points not included in the existing NPDES permit will be included in the permit. When the permit is up for renewal, in late 1993, the entire study will be completed and all stormwater discharges will be characterized. It is likely that this effort will greatly increase the number of permitted outfall points included in the NPDES permit, increasing sampling and analysis costs.

\subsubsection{NPDES Inspections and Audits}

In February 1990, the IEPA conducted a Compliance Inspection of NPDES outfalls and related facilities as well as associated sampling and analysis and record keeping requirements. The only significant deficiency was an

error in calculating and reporting mass discharge amounts on the DMR. This deficiency was corrected immediately.

\subsubsection{General Effluent and Stream Quality Standards}

In addition to specific permit conditions, ANL discharges are required to comply with general effluent limits contained in 35111 inois Administrative Code, Chapter 1, Subtitle C, Part 304. Also, wastewater discharges must be of sufficient quality to insure that Sawmill Creek complies with the IEPA's General Use Water Quality Standards found in 35 Illinois Administrative Code, Chapter 1, Subtitle C, Part 302, Subpart B. Chapter 5 of this 
report, which presents the results of the routine environmental monitoring program, also describes the general effluent limits and water quality standards applicable to the outfalls and discusses compliance with these standards. With a few exceptions, the site was gererally in compliance with these limits.

\subsubsection{NPDES Analytical Quality issurance}

ANL conducts the majority of the analyses required for inclusion in the Discharge Monitoring Report. These analyses are conducted using EPA approved methods in 40 CFR 136. To demonstrate the capabilities of the ANL laboratory for these analyses, the IEPA requires the laboratory to participate in the DMR Quality Assurance program. The IEPA sends a series of control samples to ANL annually and the results of analyses of these samples are submitted to the IEPA for review. The proficiency of the laboratory is determined by how close the submitted samples come to the actual values. The ANL laboratory has consistently performed very well on these tests, as it did in 1990.

\subsubsection{Spill Prevention Control and Countermeasures Plan}

ANL maintains a Spill Prevention Control and Countermeasures (SPCC) plan as required by the Clean Water Act ( 40 CFR 112), the Toxic Substances Control Act ( 40 CFR 761), and the Resource Conservation and Recovery Act (40 CFR 265, Subpart D). This plan describes the actions to be taken in case of a spill or other accidental release of hazardous materials into the environment. Persons with specific duties and responsibilities in such situations are identified, as are reporting and recordkeeping requirements mandated by the various regulations. Effective use of this plan is ensured by regular training, including both classroom instruction and field exercises. This plan was revised and updated in 1989 and is scheduled for revision in 1992 .

The ANL site has few hazardous chemicals present in amounts large enough to cause concern beyond the immediate spill area should a spill or release occur. Gasoline, fuel oil, chlorine, and sulfuric acid are the only hazardous chemicals present in large amounts that could be subject to spills 
or releases. While there are hundreds of other hazardous chemicals in use throughout the site in small quantities, a spill of one of these would be expected to have a negligible impact on the environment or the health of anyone outside of the immediate spill area.

\subsection{Resource Conservation and Recovery Act}

The Resource Conservation and Recovery Act (RCRA) was enacted in 1976 and implementing regulations were promulgated in May 1980 . This extremely complex body of regulations is intended to insure that hazardous wastes are disposed of in an environmentally safe manner and that facilities that treat, store, or dispose of hazardous waste do so in a way that protects human health and the environment. The Hazardous and Solid Waste Amendments of 1984 (HSWA) created a set of restrictions on land disposal of hazardous wastes and require that releases of hazardous waste or hazardous constituents from any solid waste management unit located on the site of a RCRA permitted facility be cleaned up, regardless of when the waste was placed in the unit or if the unit was originally intended as a waste disposal unit. As discussed below, these provisions, termed RCRA corrective action provisions, will have far reaching impact on ANL. The RCRA program includes regulations governing management of underground storage tanks containing hazardous materials or petroleum products. The IEPA has been authorized to administer most aspects of the RCRA program in 111 inois.

\subsubsection{Hazardous Waste Treatment and Disposal}

Because of the nature of the research activities conducted at ANL, small quantities of a large number of waste chemicals are generated. Many of these materials are classified as hazardous waste under RCRA. A number of these wastes also exhibit significant levels of radioactivity, making them mixed wastes. Mixed wastes are regulated by both the IEPA, by virtue of the hazardous chemical component and by DOE, by virtue of the radiological component. Most hazardous wastes are collected by the ANL Waste Management Operations (WMO) Department from individual generators and shipped off-site for disposal at an approved hazardous waste disposal facility. Small quantities of certain types of hazardous waste are treated on-site. 
To provide for on-site management of hazardous and mixed wastes before offsite shipment or on-site treatment, ANL operates several RCRA permitted storage facilities. These facilities, designed and operated in compliance with RCRA requirements, allow for accumulation and processing of waste and storage of waste pending identification of a disposal site. Several of the mixed wastes generated on-site do not have any approved disposal mechanism. As a result, some waste is being stored indefinitely until such a disposal mechanism becomes available. A variety of facilities are used for these activities, including several buildings formerly used for research activities which have been converted to storage or treatment facilities. In addition to the storage areas, there are currently four active units used for treatment of small quantities of hazardous waste. Two of the units are used for treatment of water reactive alkali metals. The remaining two units are used for elementary neutralization of acidic or basic wastes. Elementary neutralization units are exempt from RCRA permitting requirements. Table 2.2 lists the on-site RCRA permitted storage and treatment units. The current Part $A$ (interim status) application lists two units which are now inactive. These units, shown in Table 2.2, are the water reaction tank, used in the past for treatment of alkali metals and other water reactive materials, and the shock-sensitive treatment area, used for treatment of highly unstable or explosive materials. Both units are located in the 317 Area. These units are scheduled to undergo closure as soon as the proposed closure plans submitted with the Part B permit application discussed below are approved. They will then be removed from the permit.

\subsubsection{Permit Status}

Argonne was granted interim status under RCRA by submitting a Part $A$ application in 1980. In 1990, a new Part B permit application, one had previously been sent to the EPA but not acted upon, was prepared for submittal to the IEPA, since the IEPA has now been granted authority to administer the RCRA program. The application was submitted to the IEPA and EPA on December 21, 1990. Besides being updated and prepared to comply with changes in RCRA and IEPA regulations, the application was modified to include information required to comply with the RCRA/HSWA corrective action provisions. The review period for such a complex application is frequently 
TABLE 2.2

Hazardous Waste Treatment and Storage Facilities

\begin{tabular}{|c|c|c|}
\hline Description & Location & Purpose \\
\hline \multicolumn{3}{|l|}{ Current Interim Status Facilities } \\
\hline Waste Treatment and Storage & Building 306 & $\begin{array}{l}\text { Primary facility for treat- } \\
\text { ment, accumulation, packag- } \\
\text { ing and short term storage } \\
\text { of hazardous and mixed waste }\end{array}$ \\
\hline Container Storage Area & Building $325 \mathrm{C}$ & $\begin{array}{l}\text { Storage of containers of } \\
\text { waste }\end{array}$ \\
\hline Mixed Waste Container Storage & Building 329 & $\begin{array}{l}\text { Storage of containers of } \\
\text { mixed liquid wastes }\end{array}$ \\
\hline Dry Mixed Waste Storage Area & Building $374 \mathrm{~A}$ & $\begin{array}{l}\text { Storage of containers or } \\
\text { solid objects (e.g., lead } \\
\text { bricks) containing hazardous } \\
\text { or mixed waste materials }\end{array}$ \\
\hline Alkali Metal Reaction Booth & Building 206 & $\begin{array}{l}\text { Destruction of water reac- } \\
\text { tive alkali metals }\end{array}$ \\
\hline Alkali Metal Reaction Booth & Building 308 & $\begin{array}{l}\text { Destruction of water reac- } \\
\text { tive alkali metals, possibly } \\
\text { contaminated with radio- } \\
\text { nuclides }\end{array}$ \\
\hline
\end{tabular}

Interim Status Facilities to be closed

Water Reaction Tank $\quad 317$ Area

Destruction of water reactive alkali metals and other reactive chemicals

Shock Sensitive Treatment Area 317 Area

Treatment (detonation) of extremely reactive, or shock-sensitive wastes

Additional Facilities Included in the Part B Permit Application

Mixed Waste Storage Pad

Mixed Waste Container Storage Area
317 Area

Building 200, M-Wing
Outdoor storage pad for large, bulky objects containing mixed waste (e.g., lead casks)

Area within radioactive materials vault proposed for for storage of containers of dry mixed waste 
several years in length. In the meantime, ANL will continue to abide by interim status standards found in 40 CFR 265 and 35 IAC Part 725.

\subsubsection{Hazardous Waste Generation}

ANL typically generates several thousand gallons of a wide variety of hazardous waste and mixed waste each year; however, in 1990, the quantity of waste increased dramatically. In an effort to rid the laboratory of surplus, outdated chemicals, the Laboratory initiated a site wide cleanup program. This program resulted in the disposal of 268,700 liters $(71,000$ gallons) of hazardous wastes. Most of material was picked up directly from the generators (1aboratories) and shipped to a disposal site by an IEPA permitted hazardous waste disposal company. In addition, small quantities of certain hazardous chemicals were treated on the site in the permitted treatment units. These units render the waste nonhazardous and allow disposal in the normal refuse or in wastewater. During 1990, 6,578 1iters (1738 gallons) of waste were treated on site, primarily by elementary neutralization.

\subsubsection{Facility Modifications}

In an effort to bring the waste management facility into compliance with the more restrictive RCRA standards for a permitted Treatment Storage or Disposal facility (TSD) found in 40 CFR 264 and 35 IAC Part 724, several parts of the waste handling system underwent major rehabilitation work during 1990. Many of the storage and work areas within Building 306 were modified by the installation of berms, sealing of floors and installation of improved ventilation systems. Improved safety equipment was installed, as were special cabinets for storage of flammable liquid wastes.

Plans are being finalized to refurbish Building 306. In addition, a new radioactive and hazardous waste storage building is also being planned. These projects are scheduled for late 1991 or 1992 . The Part A permit will be revised before construction of these facilities is begun. The Part $B$ permit application will be revised to incorporate these facilities when the final design details are known. 


\subsubsection{Mixed Waste Handling}

Mixed wastes are governed by both RCRA and Atomic Energy Act (AEA) regulations or DOE Orders and factlittes storing or disposing of mixed waste must comply with RCRA permitting and facllity standards. Argonne generates several types of mixed wastes, including acids or solvents contaminated with radionuclides. Mixed wastes are treated to remove the hazardous characteristic (e.g., by acid/base neutralization) before off-site disposal. Mixed wastes that cannot be rendered non-hazardous are stored pending future disposal. The Part B application addresses mixed-waste management procedures.

\subsubsection{RCRA Inspections}

A RCRA compliance inspection was conducted by the IEPA in May of 1990 which identified four minor procedural violations. A pre-enforcement conference letter was received in July 1990. All compliance problems raised in this letter were successfully resolved by August 1990.

\subsubsection{Underground Storage Tanks}

In response to the new underground storage tank regulations, ANL has prepared a Site-Wide Underground Tank Compliance Plan. The ANL site currently contains 25 existing underground storage tanks and 33 tanks have been removed over the last several years. The majority of these tanks are being used, or were used in the past, for storage of fuel oil for emergency generators or space heaters. The on-site vehicle maintenance facilities use underground gasoline and methanol tanks. Several tanks are only used for nonregulated materials, such as steam condensate, and are not affected by the new regulations. The compliance Plan sets out a two-phase program for removal of unused underground tanks and the replacement or upgrading of tanks that must remain underground for safety considerations.

Work on this plan was begun in mid-1989. As each tank is removed, a number of soil samples are collected and submitted to an independent 1aboratory for analysis for BETX (benzene, ethyl benzene, toluene, and xylene) 
and, for tanks which contained diesel fuel, polynuclear aromatic hydrocarbons (PNAs). Any soll found to be contaminated is excavated and shipped offsite for disposal. A final set of soll samples is then collected and analyzed to confirm that all contamination had been removed. Of the 24 tanks removed during the first phase of the program, 15 were found to have some degree of exterior contamination from leaks, sp $111 \mathrm{~s}$, or overf $111 \mathrm{~s}$. The IEPA was notified of the contaminated sites. All but one of these contaminated sites were successfully cleaned up and fllled (clean closure). At one site, very close to an extsting maintenance bullding, contaminated soll was found to extend under the building foundation. As much of the soll as possible was removed; however, the contaminated soll directly under the building was left in place so as not to compromise the stability of the bullding. Argonne has petitioned the IEPA to allow a "dirty" closure of this site, meaning that the contamination under the buflding will be left in place and monitoring of the site will continue to ensure that the contamination does not migrate from the current location.

The remainder of the tank removal and upgrade program is scheduled for 1991 and 1992. During this period, regulated underground tanks st 111 in use wil1 be removed, replaced, or upgraded to current technical requirements (secondary containment, corrosion protection, leak detection, double-walled piping, spil1 and overfil1 protection).

\subsubsection{Corrective Action for Solid Waste Management Units}

As mentioned previously, the HSWA amendments added language to RCRA ( 40 CFR 264.101) requiring that any Part B permit issued must include provisions for corrective actions for all releases of hazardous matertals from any solid waste management unit (SWMU) at the site, regardless of when the waste was placed in the unit. When issued, the Part B permit will contain a compliance schedule which will govern the characterization and remediation of these sites, if remediation is found to be necessary. The Part B permit submitted to the IEPA contained information on 56 SWMUs, both active and inactive. The majority of these sites are believed to contain little or no residual contamination; however, a number may be required to undergo some 
type of corrective action. The process of conducting detailed characterization studies to determine if hazardous materials have been released from a number of these units was begun in 1989. A summary of the results of these investigations can be found in Chapter 6 . Information developed by these studies was submitted to the IEPA with the Part B permit application.

\subsection{Solid Waste Disposal}

Nonhazardous and nonradioactive solid waste generated on-site is disposed of in a sanitary landfill located in the 800 Area. This facility has been in operation since 1969. It received a operating permit from the IEPA in 1981. The operation of this facility is governed by IEPA regulations contained in 35 IAC Part 807 . The IEPA, using the services of the DuPage County Department of Environmental Concerns, conducts monthly inspections of the landfill to insure compliance with these regulations. Except for a few minor problems related to several small leaks of leachate from the landfill, there were no major problems during 1990. It was discovered in late 1990 that large portions of the landfill have reached or exceeded the maximum permitted elevations. A supplemental permit application was prepared and submitted to the IEPA in early 1991 requesting that the final elevations be increased to allow continued use of the factlity.

The IEPA promulgated new regulations governing the construction and operation of sanitary landfills in September 1990. Under provisions of these regulations, existing landfills are allowed to operate under existing regulations as long as they initiate closure by September 1992. Operation beyond this point makes the landfill subject to much more stringent and costly requirements contained in the new regulations. Since the ANL 1 andfill is already nearing its final capacity, the decision was made to close it by the September 1992 deadline. A revised closure plan was prepared and submitied to the IEPA in early 1991.

\subsection{National Environmental Policy Act}

The National Environmental Policy Act (NEPA) of 1969 established basic Federal Government policy to restore and enhance the quality of the human 
environment and to avoid or minimize any adverse effects that governmentsponsored projects would have on the environment, including historic or cultural resources. To ensure compliance with this policy, NEPA requites that projects with potentially significant impacts be carefully reviewed through the generation of either an Environmental Assessment (EA) or Environmental Impact Statement (EIS). This review process is designed to insure that all potential impacts are identified and minimized, all avallable options are considered, and a 11 effected parties are informed and given opportunity to coinment on the project.

The DOE implementation of NEPA regulations has been undergoing significant changes in the last year. The threshold at which projects are subject to NEPA review has been reduced to such an extent that virtually all activities are now requtred to undergo some sort of NEPA review and documentation. The 1ist of Categorical Exclusions, which is a list of project types that normally do not require an EA or EIS, is being expanded to help streamline the process.

The ANL NEPA compliance program is designed to ensure that all activities under consideration are reviewed to determine if they will have any significant environmental impacts. This program subjects each proposed project to a careful consideration of potential impacts to air (dust, gaseous effluents), water (1iquid effluents, wetland destruction), and soil (solid waste generation, construction activity), as well as impacts involving critical wildlife habitats, historic and cultural resources, radiation, noise, impact to workers and other considerations. A questionnaire is completed for each project and is used as documentation of the review of potential impacts. This form (DOE/CH Form 560) is submitted to DOE for their review and determination of the proper level of NEPA documentation. Projects that exhibit potentially adverse impacts in any area are subject to further review, including preparation of one of the offictal NEPA documents mentioned previously if the extent of potential impacts warrants such detailed review. Official NEPA documents (EA or EIS) are prepared by ANL and reviewed by DOE according to the procedures specified in DOE Order 5440.1D and DOE/CH Order 5440.1C. 
During 1990, a large number of projects were submitted to DOE for review. Most of them were relatively minor construction and maintenance operations with no significant impacts. The majority of these projects were determined to be categorical exclusions requiring no additional documentation. Several projects, including the construction of the CWDD, were not clearly categorical exclusions and were required to submit Environmental Assessments to allow for a more detalled review of potential impacts. The CWDD EA is currently being reviewed by DOE. There are currently no active projects at ANL which have been required to submit an Environmental Impact Statement.

During the last several years, the only major project subjected to NEPA review is the construction of the Advanced Photon Source (APS) factlity. This facility will be an advanced particle accelerator used to generate intense beams of $X$-rays for a variety of research applications. Its potential environmental impacts were documented in an EA, which was submitted to DOE in 1987. This document was approved by DOE in early 1990 and a Finding of No Significant Impact (FONSI) was issued. This FONSI cleared the way for the start of construction, which began in early 1990. The major environmental consideration described in the EA was the presence of several smal1 wetlands that will be displaced by the factlity. The first phase of the construction was the replacement of these wetlands with several man-made wetlands situated around the factlity.

\subsection{Safe Drinking Water Act}

The Safe Drinking Water Act (SDWA) of 1974 established a program to ensure that public drinking water supplies are free of potentially harmful materials. This mandate is carried out through the institution of drinking water quality standards, such as Maximum Contaminant Levels (MCL) and Maximum Contaminant Level Goals (MCLG) as well as through imposition of well head protection requirements, monitoring requirements, treatment standards, and regulation of underground injection activities. The SDWA established Primary and Secondary National Drinking Water Regulations, which set forth requirements to protect human health (primary standards) and provide aesthetically acceptable water (secondary standards). 


\subsubsection{Applicability to ANL}

The drinking water supply at ANL consists of four on-site wells that supply raw water to the water treatment plant. The treatment plant removes tron; softens the water by ton-exchange, and adds chlorine before pumping it to the site-wide distribution system. This system is classified by the State of I11tnots as a non-transient, non-community water supply, and as such is subject to most, but not a11, of the provisions of the National Primary Drinking Water regulations. In addition, the State of I11inois also regulates water supplies through Title 77, 111inois Administrative Code, which establishes a monttoring program, design, operation and maintenance requitrements and secondary water qualtty standards.

\subsubsection{Monitoring Requirements}

The primary drinking water standards establish certain monitoring and analytical requirements. Argonne samples each of the four wells and the treated water annually for radiological analyses. The water has consistentiy been in compliance with primary and secondary standards with the exception of TDS and turbidity. Chapter 6 of this report presents a detalled discussion of the results of the drinking water program. However, ANL is in the process of reviewing the drinking water monttoring program in order to fuliy assure compliance with the monttoring requirements.

\subsection{Federal Insecticide, Fungicide and Rodenticide Act}

The Federal Insecticide, Fungicide and Rodenticide Act (FIFRA) establishes a program to register pesticides, regulate their transportation and disposal, and determine standards for their use. Within ANL, all applications of pesticides are by licensed contractors who provide any pesticides used and remove any unused portions. Herbicides are rarely used, but when they are needed, a licensed contractor is brought in to apply them. In these situations, ANL will typically purchase the herbicide directly and ensure that it is used properly and that any residue is disposed of in accordance with applicable regulations. Argonne, through DOE, will notify the EPA before such an application is begun. 
2.8. Comprehensive Environmental Response, Compensation arid Ljabtlity Act

The Comprehensive Environmental Response, Compensation and Liablitty Act (CERCLA) provides the regulatory framework and funding necessary to clean up closed and abandoned hazardous waste disposal sites. Under this framework, the EPA collects data regarding sites subject to CERCLA action through generation of a Preliminary Assessment (PA) report followed up by a Site Investigation (SI). Based on the data collected, the sites are ranked according to their potential to cause human health impacts or environmental damage. The sites with the highest ranking are placed on the National Priority List (NPL) and are subject to mandatory cleanup actions, funded efther by Potentially Responsible Parties (PRPs) or by the allocation of superfund money to the project. Federal agencies are responsible for their own cleanup cost.

\subsubsection{CERCLA Program at ANL}

In the past, Federal factlittes were allowed to develop and manage their own independent CERCLA program subject to EPA oversight. The DOE's CERCLA program was detafled in DOE Order 5480.14. Under the provistons of this Order, in July 1986, ANL submitted preliminary assessment (PA) reports to DOE for the seven inactive units on the current ANL site and one inactive unit located on land given to DuPage County in 1973 as shiown in Table 2.3. Because of changes in the EPA CERCLA program brought about by the Superfund Amendments and Reauthorization Act (SARA) of 1986, the EPA is now required to publish a comprehensive inventory of Federal factlity sites known as the Federal Agency Hazardous Waste Compliance Docket. These sites are ranked, using the HRS, and placed on the NPL list if they score high enough. However, since they are Federal facilities, superfund money is not avatiable to support cleanup operations. In support of this effort, the EPA required submittal of PA reports for sites at ANL (as 1tsted in Table 2.3). These reports were submitted in April 1988. Four sites not included in the original DOE submittal were included in the subsequent submission. In late 1990, ANL prepared and submitted one adfitional PA for a solvent disposal site used for a number of years by the ANL paint shop for disposal of waste paint 
TABLE 2.3

List of Inactive Waste Disposal Sites at ANL Described in Varlous CERCLA Reports

\begin{tabular}{|c|c|c|c|}
\hline Site Name & DOE/CERCLA & USEPA/SARA & USEPA/SSI \\
\hline \multicolumn{4}{|l|}{ Waste Sites on Current ANL Property } \\
\hline $\begin{array}{l}800 \text { Area Landft11 and French } \\
\text { Dratn }\end{array}$ & $x$ & $x$ & $x$ \\
\hline $\begin{array}{l}319 \text { Area Landf } 111 \text { and French } \\
\text { Drain }\end{array}$ & $x$ & $x$ & $x(1)$ \\
\hline $\begin{array}{l}\text { Landffl11 East-Northeast of the } \\
319 \text { Area }\end{array}$ & $x$ & $x$ & $x(1)$ \\
\hline $\begin{array}{l}\text { Compressed Gas Cylinder Disposal } \\
\text { Area, } 318 \text { Area }\end{array}$ & $x$ & $x$ & $x(1)$ \\
\hline French Drain, 317 Area & $x$ & $x$ & $x(1)$ \\
\hline Mtxed Waste Storage Vaults, 317 Area & & $x$ & $x(1)$ \\
\hline Shock Treatment Facflity, 317 Area & $x$ & $x$ & $x(1)$ \\
\hline $\begin{array}{l}\text { Wastewater Holding Basin, Sewage } \\
\text { Treatment Plant }\end{array}$ & & $x$ & \\
\hline $\begin{array}{l}\text { Liquid Waste Treatment Facillty, } \\
\text { Butlding } 34\end{array}$ & $x$ & $x$ & \\
\hline $\begin{array}{l}\text { Decommisstoned Reactor } C P-5 \text {, } \\
\text { Building } 330\end{array}$ & & $x$ & $x$ \\
\hline Gasoline Spi11, Gasoline Station & & $x$ & \\
\hline \multicolumn{4}{|l|}{$\begin{array}{l}\text { Waste Sites on 01d ANL Property, } \\
\text { Currently Waterfall Glen Forest Preserve }\end{array}$} \\
\hline $\begin{array}{l}\text { Reactive Waste Disposal, Underwriters } \\
\text { Pond }\end{array}$ & $x$ & $x$ & \\
\hline
\end{tabular}

(1) All units located in the 317/319/ENE Area were described in a single Site Screening Investigation (SSI) report. 
solvents. The site in Waterfall Glen Forest Preserve is currently owned by DuPage County and thus is no longer part of a Federal facility subject to SARA. The PA for this site was submitted in an effort to inform the EPA of past $A N L$ activities.

During early 1990, the EPA requested that ANL submit Site Screening Investigation (SSI) reports for six of the twelve sites. Upon further discussions between the EPA and DOE, one of the three sites was eliminated from consideration and the units (317/319/ENE) were treated as a single site due to their physical proximity. As a result, three SSI reports were completed and submitted to the DOE in December, 1990. They were subsequently transmitted to EPA in January, 1991. Table 2.3 1ists those sites for which a SSI was submitted.

\subsubsection{CERCLA Remedial Actions}

Remedial actions to clean up any release of hazardous materials from these sites could occur in a number of different ways. Since all but one of the CERCLA sites are on ANL property and are included as SWMUs in the RCRA Part $B$ permit application, they are subject to RCRA corrective actions and come under the authority of the IEPA. It has been EPA policy, whenever CERCLA and RCRA overlap, to let the RCRA process govern the activity. This is likely to be what happens at AN'.. However, since several of the sites: contain radiological contamination, over which RCRA has no authority, it is likely that the sites may be subject to a combined RCRA/CERCLA action.

Regardless of which regulatory vehicle is ultimately used to facilitate the cleanup of these sites, the DOE, through various initiatives put forth by the Secretary of Energy, has made the commitment to voluntarily clean up all such sites within the next 30 years, wherever possible returning them to unrestricted use. As a response to these commitments, ANL has requested funding for the characterization and remediation of all but two of these sites. The two remaining sites are the one off-site unit, which is no longer under the control of ANL or DOE, and a small gasoline spill which was cumiletely cleaned up immediately after the spill occurred. Several of the 
characterization projects have already begun and will continue over the next few years.

2.8.3. Emergency Planning and Community Right to Know Act, SARA Title III

Title III of the 1986 SARA amendments to CERCLA created a system for planning for response to emergency situations involving hazardous materials and for making information regarding use and storage of hazardous materials available to the public. Under SARA Title III, ANL is required to provide an inventory of hazardous substances stored on the site, Material Safety Data Sheets (MSDS), and completed SARA data sheets (Tier I or II forms) for each hazardous substance stored in quantities above a certain threshold planning quantity (typically 10,000 lbs; but lower for certain compounds) to applicable emergency response agencies. In November 1987, an inventory and MSDS forms for nine chemicals were submitted to the Local Emergency Planning Committee (LEPC); in March 1988, Tier I reports providing additional information on these chemicals were submitted. In February 1989, Tier II report forms were completed and submitted to the LEPC. During March 1990, updated Tier II forms were submitted. These forms updated the previous 1 isting and provided more information regarding the amount of material stored and the location of the material. Table 2.4 lists hazardous compounds reported under SARA Title III for 1990.

Section 304 of SARA Title III requires that the LEPC and state emergency planning agencies be notified of accidental or unplanned releases of certain hazardous substances to the environment. To ensure compliance with such notification provisions, the SPCC plan for ANL was modified to include SARA Title III requirements. No incidents during 1990 required notification of the LEPC.

\subsection{Toxic Substances Control Act}

The Toxic Substances Control Act (TSCA) of 1976 provides for testing of manufactured substances to determine toxic or otherwise harmful characteristics and regulation of the manufacture, distribution, use, and disposal of reguilated substances. The oniy iśçA-reguiated comipüunús iñ sigñificant 
TABLE 2.4

Compounds Reported Under SARA Title III

\begin{tabular}{|c|c|c|c|c|c|}
\hline \multirow[b]{2}{*}{ Compound } & \multicolumn{5}{|c|}{ Hazard Class } \\
\hline & Fire & $\begin{array}{c}\text { Sudden Release } \\
\text { of Pressure }\end{array}$ & Reactive & $\begin{array}{l}\text { Acute } \\
\text { Health } \\
\text { Hazard }\end{array}$ & $\begin{array}{l}\text { Chronic } \\
\text { Health } \\
\text { Hazard } \\
\end{array}$ \\
\hline Diesel Fuel & $x$ & & & & \\
\hline Gasoline & $x$ & & & & \\
\hline $\begin{array}{l}\text { Methanol/ } \\
\text { Gasoline }\end{array}$ & $x$ & & & & \\
\hline Sodium & $x$ & & $x$ & & \\
\hline Chlorine & & $x$ & & $x$ & \\
\hline $\begin{array}{l}\text { Chlorofluoro- } \\
\text { carbon } 11\end{array}$ & & $x$ & . & & \\
\hline Sodium Carbonate & & & & $x$ & \\
\hline Sulfuric Acid & & & & $x$ & \\
\hline Calcium Oxide & & & & $x$ & \\
\hline Calcium Hydroxide & & & & $x$ & \\
\hline $\begin{array}{l}\text { 0ils containing } \\
\text { PCBs }\end{array}$ & & & & & $x$ \\
\hline
\end{tabular}


quantities at ANL are polychlorinated biphenyls (PCB) contained in electrical capacitors and transformer oil. Regulations governing PCB use and disposal are given in 40 CFR 761. These regulations provide detailed requirements for use and disposal of PCB-containing mixtures (over $500 \mathrm{ppm}$ $P C B$ ) and $P C B$-contaminated mixtures (over $50 \mathrm{ppm} P C B$ ). Most of these regulations relate to PCBs contained in dielectric fluids within electrical equipment, such as transformers and capacitors.

\subsubsection{PCBs in Use at ANL}

The majority of PCBs at ANL were contained in a number of transformers, capacitors, and switches throughout the site. Starting in 1987, ANL began removing and disposing of a 11 PCB and PCB-contaminated electrical equipment. All indoor units have been removed and transported off the site for proper disposal, and all outdoor units have been removed or retrofilled. During 1990, al1 pole mounted transformers and circuit breakers containing PCBs were replaced or retrofilled with non-PCB 011 . All removal and disposal activities were conducted by licensed contractors specializing in such activities. Operation, removal, storage, and disposal of PCB-containing articles were conducted in compliance with applicable TSCA regulations.

During late 1989, it was discovered that a small sludge drying bed, servicing the laborat ury wastewater treatment plant, was contaminated with $P C B$ of unknown origin. Concentrations of over $50 \mathrm{mg} / \mathrm{kg}$ were found in the sludge and over $300 \mathrm{mg} / \mathrm{kg}$ were found in the sand below the sludge. An extensive characterization study of this site, followed by remediation of the PCB contaminated material, is being planned.

During August 1990, the EPA conducted a compliance inspection of the PCB management program. Based on this inspection, a field citation was issued for inadequate documentation of transformer inspections, late submit$\mathrm{tal}$ of a required notification form, and inadequate cleanup of a small PCB oil leak. All three violations were quickly resolved and documented in a letter submitted to the EPA in September. 


\subsection{Endangered Species Act}

The Endangered Species Act (ESA) of 1973 requires Federal Agencies, through consultation with the Secretaries of Interior and Commerce, to insure that their actions are not likely to jeopardize the continued existence of endangered or threatened species or critical habitat of such species. For ANL, the Fish and Wildlife Service has been delegated authority to conduct these consultations and enforce the ESA.

To comply with the ESA, Federal Agencies are required to make an assessment of the proposed project area to determine if any threatened or endangered species or critical habitat of these species exists. If no such species or habitat are present this fact is to be documented in a letter to the FWS. If such species or habitat are found to exist, the FWS is to be notified and a series of consultations and studies are then carried out to determine the extent of impact and any special actions which must be taken to minimize this impact.

At ANL, the provision of the ESA are implemented through the NEPA project review process. All proposed projects must provide a statement describing the potential impact to threatened or endangered species and critical habitat. This statement is included in the general project Environmental Evaluation Form. If there is potential adverse impact, this impact will be further assessed and evaluated through the preparation of a more detailed NEPA document, such as an EA of EIS.

Currently, no federally-listed endangered species are known to reside on ANL property. The northern 111 inois region, including ANL, is considered in the range of several such species; however, no suitable habitat is known to exist on the site. A number of species listed by the State of Illinois as threatened state species are known to reside on the ANL site. Impacts to these species are also assessed during the NEPA process. No project an ANL has ever been stopped, delayed or modified as a result of potential impact to endangered species. 


\subsection{National Historic Preservation Act}

The National Historic Preservation Act (NHPA) requires Federal agencies to assess the impact of proposed projects on historic or culturally important sites, structures or objects within the site of the proposed project. It further requires Federal agencies to assess all sites, buildings, and objects on the site to determine if any qualify for inclusion in the National Registry of Historic Places. It also established a permitting program for archaeological investigation activities and established a svstem of civil and criminal penalties for unlawfully damaging or removing such artifacts.

The NHPA is implemented at ANL through the NEPA review process, as well as through the internal digging permit process. All proposed actions must consider the potential impact to historic or culturally important artifacts and document this consideration in the Project Environmental Evaluation Form. If the proposed site has not been surveyed for the presence of such artifacts, a cultural resources survey is conducted and any artifacts found are carefully documented and removed. Prior to disturbing the soil, a ANL digging permit must be obtained from the PFS division. This permit must be signed by the Cultural Resources officer at ANL prior to digging to document the fact that no significant cultural resources will be impacted.

The ANL currently does not contain any sites, buildings or structures included in the National Register of Historic Places. It does, however, contain several facilities which represent historically important scientific or technical achievements, such as the first experimental boiling water reactor. If it is determined that such sites are suitable for listing, they will be investigated and submitted to the Department of Interior for possible listing.

\subsection{Flood Plain Management}

Federal policy on managing flood plains is contained in Executive order 11988 (May 24, 1977). This order requires Federal facilities to avoid to 
the extent possible adverse impacts assoctated with the occupancy and modifications of floodplains. All projects proposed for construction in a floodplain must demonstrate that there is no reasonable alternative to the floodplain location.

The ANL site is located approximately 150 feet above the nearest larye body of water (Des Plaines River) and thus is not subject to major flooding. A number a small areas, associated with Sawmill creek and other small streams or low-lying areas, are subject to local flood conditions following extremely heavy precipitation. To insure that these areas are not adversely impacted, ANL has maintained a practice of not permitting significant construction within these areas, unless there is no practical alternative. Any impact to flood plains are fully assessed and documented in the NEPA documents prepared for the proposed project.

\subsection{Protection of Wetlands}

Federal policy of wetland protection is contained in Executive orders 11990, and in 10 CFR Part 1022, which describes DOE's implementation of this order. This order require Federal agencies to identify potential impact to wetlands resulting from proposed activities and to minimize these impacts. Where impacts cannot be avoided, action must be taken to mitigate the damage by repairing the damage or replacing the wetland with an equal or greater amount of a man-made wetland as much like the original wetland as possible. The current DOE policy is for no net decrease in the amount of wetland as a result of DOE activities.

Due to the topography and nature of the soil at ANL, the site contains a significant number of natural and man-made wetlands. These range from small stormwater ditches which are overgrown with cattails to natural depressions, beaver ponds and man-made ponds. The potential impact to these areas caused by a proposed action is described in the NEPA Project Environmental Evaluation Form for the project. If the potential impact is thought to be significant, the DOE will require preparation of an EA or EIS. The APS project, currently under construction, required extensive wet 1 and mitigation activities since several small natural wetlands occupied the 
construction site. These actions were documented in the EA which was approved in early 1990.

\subsection{Current Issues and Actions}

The purpose of this section is to summarized the most important issues related to environmental protection encountered during 1990 . Since preceding sections of this chapter contain detailed discussions of specific issues related to each major piece of environmental regulations, discussions of spectfic issues will not be repeated in this section. Please refer to the appropriate section of this chapter for these details.

\subsubsection{Major Compliance Issues}

The most significant ongoing issues encountered at ANL during 1990 involve compliance with existing permit requirements, such as frequent exceedances of the boller house air permit and the NPDES wastewater discharge permit. These violations are primarily the result of aging or inadequate equipment and facilities, as well as increasingly stringent limits. A number of corrective actions are underway or planned to upgrade or construct the necessary facilities. These projects are contained in the five Year Plan, discussed in Chapter 3.

The acquisition of the necessary permits to conduct the various activities on site is a second major issue. A number of currently unpermitted air emission sources exist on site, including fume hoods and ventilation systems emitting radionuclides. A program of inspections and audits was begun in late 1990 to identify these sources and prepare permit applications for them. In addition, ANL submitted its RCRA Part B permit application the EPA and IEPA in late 1990. This application is a major undertaking which will take several years to complete. Significant modification and upgrading of the hazardous waste management facilities are underway to comply with anticipated permit requirements.

The final major issue relates to the identification and clean-up of environmental contamination caused by previous activities on the ANL site. 
These activities come under the purview of the RCRA and CERCLA programs administered by the EPA and IEPA. The ANL site has a significant number of such sites which will probably require extensive remediation to remove residual contamination resulting from past activities. The Five Year Plan contains a number of projects, termed Environmental Restoration projects, to provide for characterization and remediation of the sites. Several characterization projects are ongoing while others are planned for the next few years. Remedial actions are scheduled to begin within three years, depending on the results of the characterization studies.

\subsubsection{Regulatory Agency Interactions}

The regulatory agency interaction with ANL during 1990 was primarily limited to normal written correspondence regarding permit requirements and related issues. A notice of violation was received for the boller house air emissions and for several procedural deficiencies identified in the annual RCRA inspection. All non-compliance issues raised in the NODs were negotiated to the satisfaction of the IEPA, ANL and DOE. There are currently no ongoing outstanding compliance issues or agreements or pending enforcement actions against $A N L$.

The NPDES permit contains a compliance date of June 30, 1990, for construction of a treatment system to control chlorides in the wastewater discharge. As discussed in Section 2.2.1.1, this treatment plant is no longer considered a viable solution to the chloride and TDS violations. An alternative solution, to reroute the speni regenerant brines to the DuPage County sewer system, was proposed to the IEPA and was accepted. The necessary sewer line extension was constructed in early 1991 and should be in service by late 1991. The NPDES permit will be revised to remove the compliance date once the system is operational.

\subsubsection{Tiger Team Assessment}

During 1989, the Secretary of Energy initiated a program to assess environment, safety and health programs at all DOE facilities. This program is based upon an intensive on-site assessment conducted by groups of ES\&H 
specialists termed Tiger Teams. During late 1990 ANL was the subject of a Tiger Team assessment. The team was composed of approximately 60 individuals who visited the site from September 17 through October 19, 1990. A sertes of site inspections, employee interviews and records audits were conducted. On October 19, 1990, a closeout meeting was held and a draft report issued which contained the findings of the investigation, broken down into the areas of environmental protection, safety and health and management and organization. The environmental subteam identified 84 findings related to areas such as air, surface water, waste management, radiation, inactive waste sites, environmental management and several others. The findings ranged from relatively minor concerns, such as the use of $\mathrm{pH}$ standards past the expiration date, to far reaching concerns such as deficiencies in the management of environmental restoration projects and various deficiencies related to radiological monitoring and quality assurance practices. These findings represented potential non-comp 1 iance with environmental regulations and non-attainment of acceptable best management practices; however, none of the deficiencies noted represent an immediate risk to public health or the environment.

In preparation for this Tiger Team, ANL conducted an internal appraisal and generated a self assessment report containing 239 findings related to environmental protection. Immediate action was taken on a large number of these findings to resolve issues prior to the Tiger Team visit, however, many could not be resolved before the Tiger Team arrived and ended up being identified as findings in the Tiger Team report.

To resolve the deficiencies identified by the Tiger Team and the ANL self assessment, an Action Plan was prepared in December 1990. This plan lists specific actions to be taken to resolve each Tiger Team finding and many of the self assessment findings. This document was submitted to DOE headquarters in early 1991 for approval. A number of the activities 1isted in the Action Plan were either ongoing actions or previously planned actions, many of which appear in the Five Year Plan. In addition, a series of new activities, not previously anticipated, were identified. These activities will be started in 1991, providing additional funding is provided by the DOE. An internal tracking system is being developed to insure that the 
various commitments contained in the Action Plan are satisfied and the milestones are met.

One of the major needs identifted by the Tiger Team was for an internal oversight group within ANL which could verify that appropriate regulations are being complied with and that adequate resources were avallable for ESH functions. This need was met with the establishment of a new position of Assistant I aboratory Director for ESH/QA Oversight. This individual reports directly to the Laboratory Director and is responstble for independent oversight of the various ESH activities and programs as well as ESH policy development and strategic planning. One of the principal responsibilities of this position is to serve as chairman of the ESH/QA Oversight Directorate. This committee will assist in the development of Laboratory policy and in the strategic planning functions of the Assistant Laboratory Director.

\subsection{Environmental Permits}

Table 2.5 lists all environmental permits in effect at the end of 1990 . Table 2.6 lists all permits which were etther renewed or granted for the first time during 1990. Other portions of this Chapter discuss special requirements of these permits and compliance with those requirements. The results of monitoring required by these permits are discussed in those sections, as well as in Chapter 5. As mentioned in Section 2.1, a number of air pollution permit applications have been submitted to the IEPA or are being prepared.

\subsection{Compliance Summary for the First Quarter of 1991}

This section summarizes new regulatory compliance issues which developed from January 1, 1991 to April 1, 1991. It also reports on developments in compliance issues which were not resolved during 1990.

\subsubsection{Clean Air Act}

Boiler No. 5 was not operated during the first quarter of 1991 since needed repairs to the air pollution control equipment have not been made. 


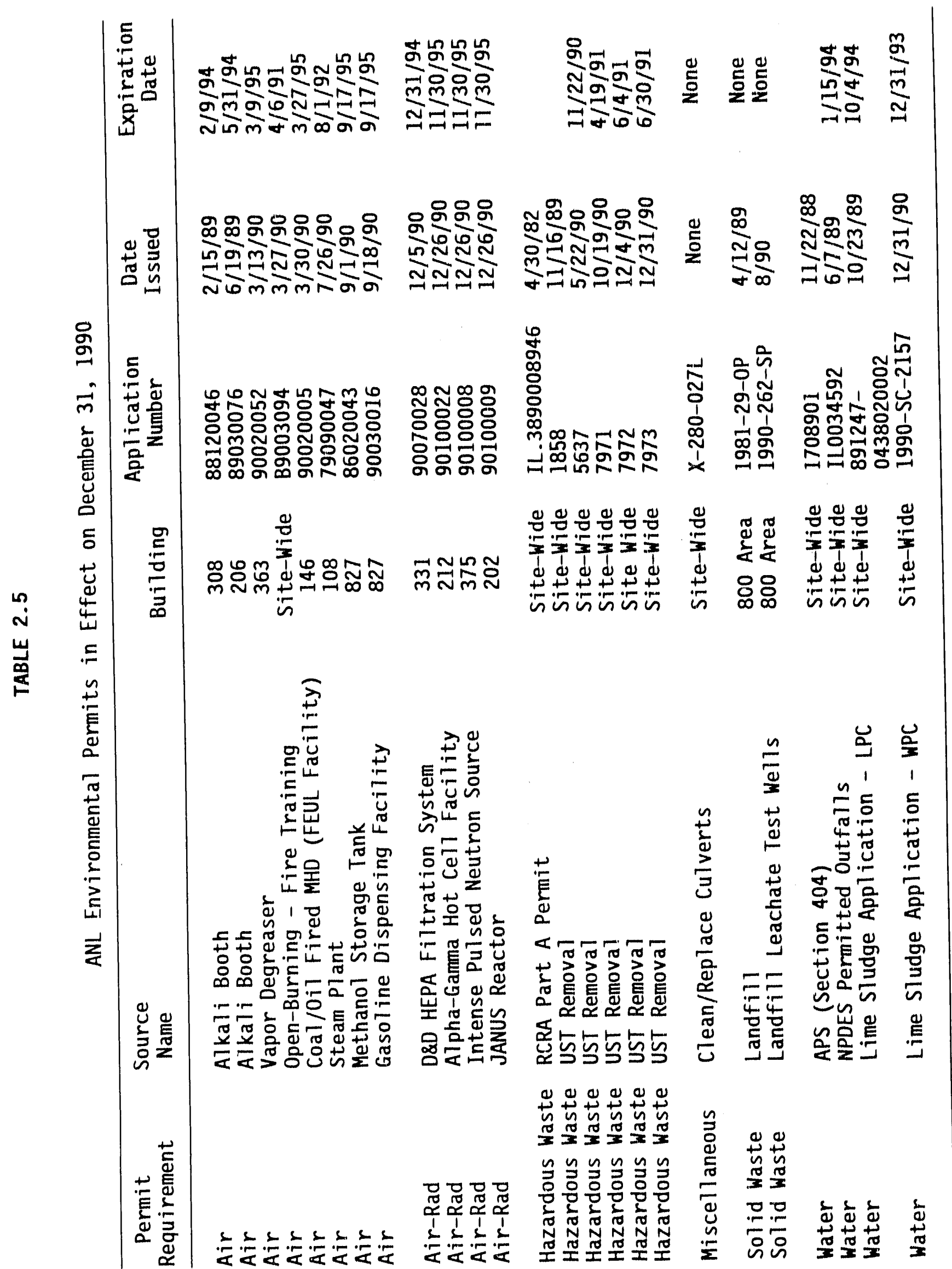




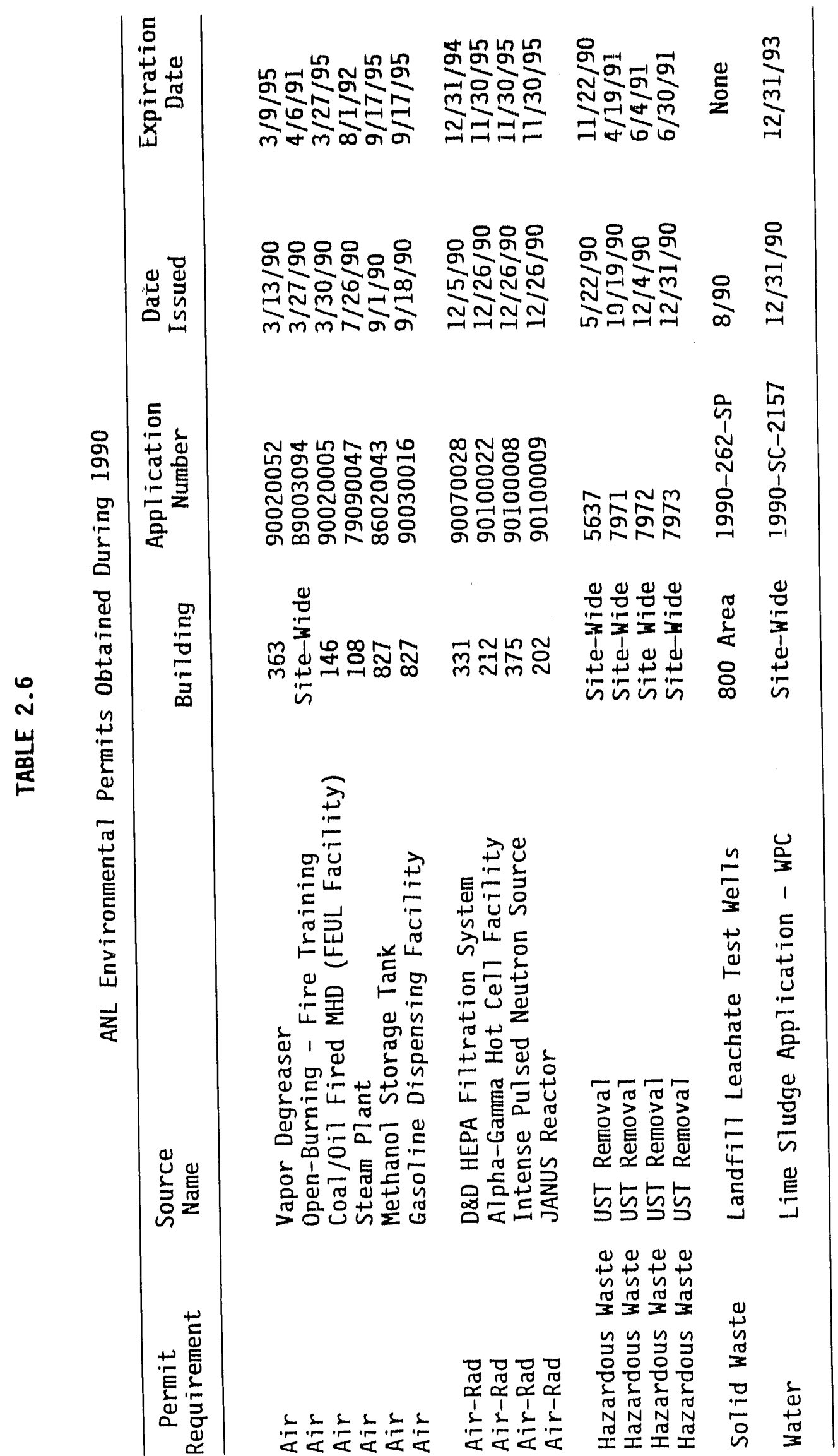


Progress on preparing the air operating permit applications for radionuclide-emitting fume hoods continued. The projected date for completion is 1ate 1991. The landf 111 has complied with the revised asbestos NESHAP and submitted historical records for asbestos disposal to the DOE.

\subsubsection{Clean Water Act}

Excursions above the permitted levels of TDS and chlorides at outfall 001 continued. The design of the new sewer connecting the water treatment plant to the DuPage County system was completed, IEPA approval of the profect was secured and construction was begun. During the first quarter of 1991, five violations of TSS levels were experienced as a result of heavy spring rains causing soll erosion. The source of several pH violations experienced at outfall 006 during 1990 was discovered. A small water demineralizer, used to treat water at a research facility, was found to be discharging acidic and basic regenerant solutions into a floor drain which discharged into a stormsewer upstream of outfall 006. This demineralizer has been shut down and replaced by a system which is recharged at the vendor's facility. An NPDES inspection was conducted by the IEPA on February 20, 1991, and no significant defictencies were found.

\subsubsection{Resource Conservation and Recovery Act}

The RCRA part B permit application was submitted to the IEPA on January 4, 1991. After a completeness review of the permit, the IEPA sent ANL a notice of deficiency requesting more documentation on waste classification procedures, safety precautions taken and many other areas. It also provided additional information on the types of facllities classified as SWMUs. As a result of this new information, a large number of additional SWMUs will be added to the permit application. This information is currentiy being assembled for transmittal to the IEPA.

In February of 1991, the IEPA conducted a RCRA compliance inspection which identified two violations. These were resolved and documented in a letter transmitted to IEPA in April 1991. 


\subsubsection{National Environmental Policy Act}

There were no significant developments regarding NEPA during the first quarter of 1991.

\subsubsection{Safe Drinking Water Act}

There were no significant developments related to the SDWA during the first quarter of 1991 .

2.16.6. Federal Insecticide, Fungicide and Rodenticide Act

There were no significant developments related to FIFRA during the first quarter of 1991.

2.16.7. Comprehensive Environmental Response, Compensation and Liability Act

ANL submitted revised Tier II forms containing information of the hazardous chemicals in use during 1990. Except for metallic sodium, the list was the same as that submitted in 1990 for 1989 . Metallic sodium was removed since the only usage of this material was in research activities only which are exempt from SARA notification requirements.

\subsubsection{Permits}

Seven air emission operating permits were issued during the first quarter of 1991, as shown in Table 2.7. Four were for conventional pollutants and three for radionuclides. A permit for installation of the sewer line to the Dupage County system was received in early $A^{\prime \prime}, i l$. 


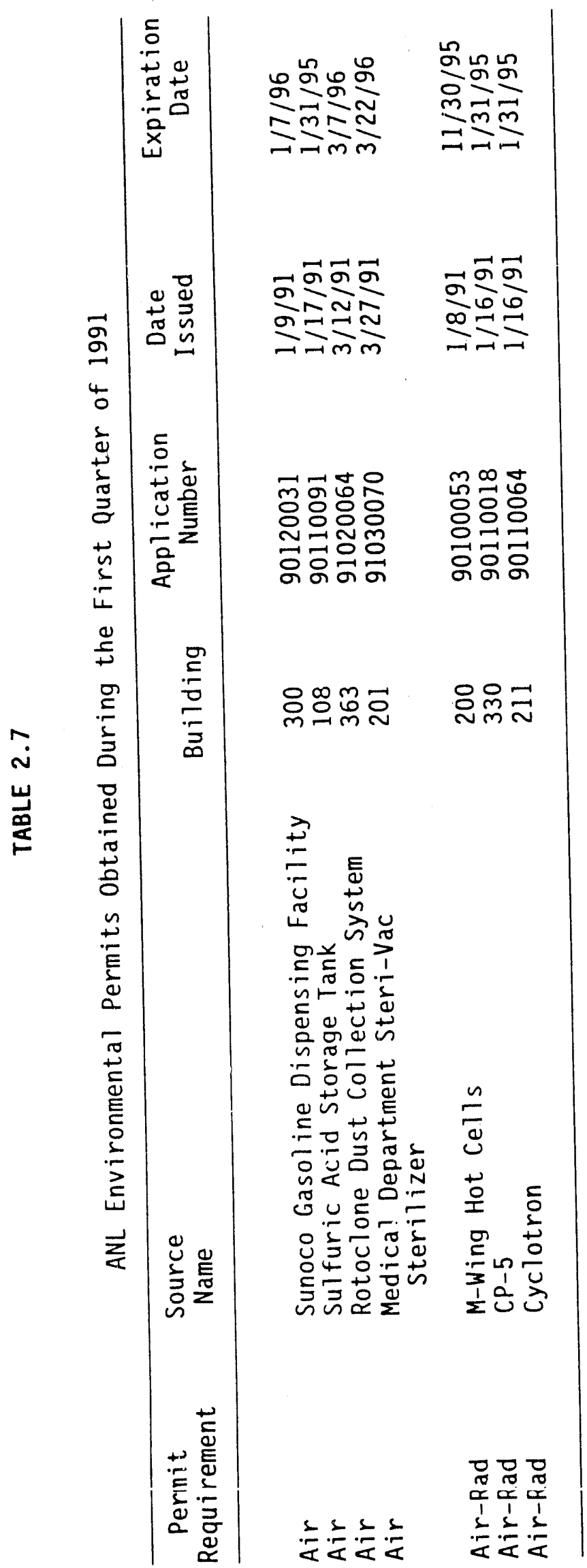




\section{ENVIRONMENTAL PROGRAM INFORMATION}

It is the policy of the DOE and ANL to conduct all operations in compliance with applicable environmental statutes, regulations, and standards and to ensure that environmental obligations are carried out consistently across all operations and organizations. Protection of the environment and human health and safety are given the highest priority. At ANL, a number of programs and organizations exist to ensure compliance with these regulations and to monitor and minimize the impact ANL operations have on the environment. Each of these activities is discussed briefly in this chapter.

\subsection{Environmental Restoration and Waste Management Program}

In 1989, the DOE established the goal of achieving compliance with applicable regulations and assessing and cleaning up releases of hazardous materials from inactive waste sites, returning all such sites to unrestricted use within 30 years. As a management tool to improve the achievement of this goal, the DOE established the Environmental Restoration and Waste Management Program. This program identifies specific needs and established a system for allocating funds to resolve the various deficiencies. Each of the DOE facilities has prepared a set of planning documents (Activity Data Sheets, or ADS) describing the activities necessary to bring that specific site into compliance and to identify and clean up inactive waste sites. These planning documents are contained in two reports which are updated and putlished annually, the Environmental Restoration and Waste Management Five Year Plan and the Site Specific Plan. Five Year Plan projects and activities are subdivided into three categories, corrective activities (those actions necessary in the short term to bring a facility into compliance with environmental regulations), environmental restoration activities (those activities necessary to identify and clean up inactive waste sites and other sites potentially contaminated as a result of DOE activities) and waste management (activities designed to ensure that hazardous and radioactive wastes are stored and disposed of safely and the volume of waste is minimized). 
The 1990 Five Year Plan contained information on 181 separate projects. The majority of these projects were proposed research and development or technology demonstration projects that were not directly related to ANL onsite activities. The on-site activities, described fully in the Site Specific Plan, included 15 corrective activity projects, 26 environmental restoration projects, and seven waste management activities. The titles of these projects are listed in Table 3.1. The Five Year Plan and the Site Specific $P l a n$ are both public documents available upon request from the DOE. Each type of project is discussed in more detail below.

\subsubsection{Corrective Actions}

The corrective activity projects at ANL generally involve the construction of new or upgraded wastewater treatment facilities used for disposal of wastewater from the ANL. As discussed in Chapters 2 and 5 , the site has experienced a number of violations of its NPDES wastewater discharge permit in recent years, The reason for many of these violations is the lack of appropriate treatment technology to comply with current effluent limits. These deficiencies will be resolved as these corrective action projects are completed. During 1990, construction of one facility, the Boiler House Waste Water Treatment Plant, was begun and design work on several other facilities was started.

\subsubsection{Environmental Restoration Activities}

Environmental Restoration Activities represent the projects designed to carry out the objective of assessing and cleaning up inactive waste sites. The ANL site contains a number of inactive waste sites used for disposal of waste during the early years of Laboratory operations. These sites include two inactive landfills, three French drains (which consisted of shallow pits used for disposal of liquid wastes), two inactive wastewater treatment facilities and a number of areas which may have been contaminated through the discharge of small amounts of hazardous chemicals. Several sites used from the 1940s through the 1970s for open burning of combustible waste and construction debris also exist. A series of ongoing and planned activities have been designed to foster the clean up of these sites. 
TABLE 3.1

Environmental Restoration and Waste Management Projects

\begin{tabular}{ll}
$\begin{array}{l}\text { AOS } \\
\text { Number }\end{array}$ & Tytle \\
\hline & \\
& Corrective Actions \\
1003 & 800 Area Landfill Leachate Collection/Treatment \\
1004 & Treatment of Boiler House Area Wastewater \\
1005 & Cooling Tower Blowdown Water Diversion \\
1006 & Laboratory Wastewater Treatment Plant Imp/Ugrade \\
1007 & UST Upgrade/Replacement \\
1008 & Freund Pond Characterization \\
1009 & Freund Pond Remediation \\
1010 & Sanitary Wastewater Treatment Plant Imp/Upgrade \\
1011 & Laboratory and Sanitary Sewer Collection System \\
1012 & Chloride Removal Plant \\
1014 & PCB Transformer Disposal \\
1016 & Water Supply Covers \\
1017 & Canal Water Treatment Rehabilitation \\
1018 & Equalization Pond Rehabilitation \\
1019 & Laboratory and Sanitary Sewer Collection System
\end{tabular}

\section{Environmental Restoration}

800 Area Landf 111 Characterization

800 Area Landfill Remediation

East Area Sewage Treatment Plant Characterization

Each Area Sewage Treatment Plant Remediation

570 Holding Pond Characterization

570 Holding Pond Remediation

Sawmill Creek Characterization

Sawmill Creek Cleanup

Lime Sludge Removal

317/319/ENE Area Characterization

$317 / 319 /$ Area Remediation

O\&O Experimental Boiling Water Reactor (EBWR)

$D \& D$ of the CP-5 Reactor

Reactor Surveillance/Maintenance

D\&D of the Hot Cells

Hot Cells Survelllance/Maintenance

$D \& D$ of the Juggernaut Reactor

D\&D of the Argonne Thermal Source Reactor (ATSR)

D\&D of the 60" Cyclotron

100 Area Characterization

Outfall Areas Characterization

CP-5 Site Characterization

Stormwater Discharge Characterization

Sewage Collection System Restoration

\section{Waste Management}


The Envirorimental Restoration projects at ANL are typically broken down into two phases, the characterization phase and the remediation phase. Several of the characterization projects were started in 1989 and 1990. Additional characterization is required before significant remediation can be undertaken. The results of some of this early characterization work is presented in chariter 6. Following the characterization phase, projects designed to dean up and dispose of residual contamination found during characteriztioll will commence.

In addition to the inactive waste site clean up projects, the Environmental Restoration section of the Five Year Plan also contains a number of Decontamination and Decommissioning (D\&D) projects for on-site nuclear facilities. The ANL site contains several inactive nuclear reactors and hot cells used in the past for processing of radioactiv materials. These facilities are either currently undergoing D\&D or are scheduled for D\&D in the next few years. The D\&D operations will remove residual radiological contamination, dispose of radiologically contaminated materials and will return the facilities to unrestricted use status. The largest such activities are the D\&D of the Experimental Boiling Water Reactor (EBWR) and the $C P-5$ research reactor.

Current technology is not adequate to properly process and dispose of many of the waste materials that may be generated by these activities. Much of the waste is a mixture of radioactive and chemically hazardous materials for which there is currently no recognized treatment or disposal processes. The Five Year Plan contains a number of research and development projects designed to develop the necessary technologies and processes to dispose of these materials safely. Many of these projects will be carried out at ANL by several of the research divisions.

\subsubsection{Waste Management}

The projects included in this section of the Five Year Plan represent activities necessary to ensure that waste materials currently being generated are properly stored, treated and disposed. A primary mo'ivation for the improvement in waste handling and disposal operation is the need to 
upgrade such facilities to comply with increasingly stringent RCRA requirements as well as other state and federal regulations and DOE orders. The majority of the Waste Management projects involve improvements to existing treatment or storage facilities.

\subsection{Pollution Prevention Program}

ANL is developing a strong Pollution Prevention program. Increasing emphasis is being placed on the recycling of all types of waste, including paper, scrap metals, wood, waste oils, and solvents. Whenever possible, waste is sent to reprocessing facilities rather than disposal facilities, thus reducing the amount of waste.

As a result of new IEPA regulations governing operation of the on-site landfill, it is currently anticipated that the landfill will be closed by September 1992. To reduce the cost of off-site disposal, a renewed emphas is is being placed on recycling and waste reduction. The assistance of waste recycling and disposal experts is being sought to develop a site wide waste management program.

During late 1990, a draft Pollution Prevention and Waste Minimization Plan was prepared. This plan sets forth a formal program for performing waste minimization audits, identifying alternatives which generate less waste when new projects aree proposed, setting waste reduction goals and documenting whether or not these goals are being met. Project-specific and Divisional waste minimization plans will be written, focusing on specific waste streams and operations. Full implementation of this plan is anticipated in late 1993.

RCRA regulations require that generators of hazardous waste indicate on the annual RCRA generator report what waste minimization activities were undertaken at the facility and the actual reduction in volume and toxicity of the wastes generated. As mentioned in Chapter 2, during 1990 a site wide program to dispose of unused or outdated chemicals resulted in the generation of large amounts of hazardous waste, much greater than previous years. 
As a result, ANL was not able to demonstrate that waste minimization was occurring.

\subsection{Environmental Monitoring Program Description}

As required by DOE Order 5400.1 , ANL conducts a routine environmental monitoring program. This program is designed to determine the effect the operation of ANL is having on the environment surrounding the site. This section describes this monitoring program. A general description of the techniques used to sample each environmental medium is provided. This is followed by the collection procedures, the sampling schedule and analytical techniques used.

\subsubsection{Air Sampling}

Continuously operating air samplers are used at ANL to measure the concentrations of airborne particulate radioactivity and tritiated water vapor. There is currently no monitoring of non-radiological air contaminants in ambient air. Particulate samplers are placed at 15 locations around the ANL perimeter and at six off-site locations, approximately five miles from ANL to determine the ambient or background concentrations. Tritiated water vapor samples are collected at two perimeter and one off-site location.

Airborne particulate samples for direct radiation measurement are collected continuously at 13 perimeter locations and at five off-site locations on glass fiber filter media. Average flow rates on the air samplers are about $70 \mathrm{~m}^{3} / \mathrm{hr}$. Filters are changed weekly. The filters on perimeter samplers are changed by ANL staff and the filters on off-site samplers are changed and mailed to ANL cooperating local agencies. The sampling units are serviced every six months and the flow meters are recalibrated annually.

Additional air samples, used for radiochemical analysis of plutonium and other isotopes, are collected at two perimeter locations and one offsite location. These samples ire rollected on special filter media which 
was changed every ten days by ANL staff. The flow rate calibration and servicing schedule is the same as discussed above.

Samples of airborne water vapor, used for analysis of tritium in air, are collected on silica gel at two perimeter and one off-site locations. Silica gel samplers are changed every three or four days. Temperature and humidity information is obtained for each sampling period to convert the volume of water collected to cubic meters of air.

Stack monitoring is conducted at those emission points that have a probability of releasing measurable radioactive effluents. The results of these measurements are used for calculating the theoretical annual off-site dose using the required CAP-88 version of the EPA-AIRDOSE atmospheric dispersion computer code and dose conversion.

At the time of sample collection, the date and time when sample collection began, the initial flow rate, the date and time when the sample was collected and final flow rate are recorded on a label attached to the sample container. The samples are then transported to the ANL Environmental Monitoring Laboratory where this information is then transferred to the ANL Environmental Protection computerized Data Management System (EMS).

Each air filter sample collected for direct measurement is cut in half. Half of each sample for any calendar week is combined with all the other perimeter samples from that week and packaged for gamma-ray spectrometry. A similar package is prepared for the off-site filters for each week. A two-inch circle is cut from the other half of the filter, mounted in a twoinch low-lip stainless steel planchet, and counted for alpha and for beta activity. The balance of the filter is saved.

The air filter samples collected for radiochemical analysis are composited by location for each month. After addition of the appropriate tracers, the samples are ashed, and then sequentially analyzed for plutonium, thorium, uranium, and strontium. 
The silica gel samples are heated in a tube furnace and the water condensed and collected. The tritfum concentration is determined by 1 lquid scintillation spectrometry.

\subsubsection{Water Sampling}

Water samples are collected to determine what, if any, radioactive materials or selected hazardous chemicals used or generated at ANL enter the environment by the water pathway. The samples are collected from Sawmill creek below the point at which ANL discharges its treated wastewater and stormwater. The results of radiological analysis of water collected at this location are compared to upstream and off-site results to determine the ANL contribution. The results of the chemical analysis are compared to the applicable IEPA stream quality standards to determine if the site is degrading the quality of the creek. These results are discussed in more detail in Chapters 4 and 5.

In addition to surface water, subsurface water samples are also collected at approximately 32 locations. These samples are collected from monitoring wells located near sites which have the potential for adversely impacting groundwater. These sites are the 800 Area landfi17, the $317 / 319$ waste management area, and the site of the inactive CP-5 reactor. Samples of the domestic water, which comes from four on-site wells, are also collected and analyzed for hazardous or radioactive constituents

Surface water samples are collected from Sawmill creek daily and manually composited into a single weekly composite sample. A continuous sampling device is being installed at this location to improve sample collection efficiency. To provide control samples, Sawmill creek is sampled upstream of ANL once a month. The Des Plaines River is sampled twice a month below, and monthily above, the mouth of Sawmill creek to Uetermine if the radioactivity in the creek had any effect on the activity in the River. Water samples are collected from remote locations in the spring and fall to serve as additional control samples. 
Subsurface water samples are collected quarterly from the monttoring wells located in the $317 / 319$ Area, $330(C P-5)$, and the 800 Area Santtary Landfil1. The monttoring wells are purged and samples collected from the recharged well water. These samples are analyzed for both chemtcal and radiological constituents, as discussed in Chapter 6 . Samples are collected quarterly from the well-heads of the four ANL wells used to provide the Laboratory domestic water supply. The water is pumped to the surface and collected in one-galion glass bottles.

At the time of sample collection for radiological analysis, the sampling location, time, date and collector identification number are recorded on a label attached to the sample container. Upon return to the laboratory, the information is transferred to the EMS system. Each sample is assigned a unique number, which accompanies it through all analyses.

After the sample has been logged in, an al fquot is removed for trittum analysis, $20 \mathrm{~mL}$ of conc. $\mathrm{HNO}_{3}$ is added per galion of water as a preservative, and the sample is filtered through Whatman \#2 filter paper to remove sediment present in the sample. Appropriate aliquots are then taken depending on the analysis.

For nonradiological analysis, samples are collected and preserved using EPA prescribed procedures. Cooling is used for organic analysis and nitric acic used to preserve samples to be analyzed for metals. Specific collection procedures are used for some other components sought and EPA methods are used. All samples are analyzed within the required holding period or noncompliance is documented. The quality control requirements of either SW846 and/or CLP are met or deviations are documented. All samples are assigned a unique number which serves as a reference source for this sample. When duplicate samples are obtained, unique numbers are assigned and the indication that duplicates exist is noted in the data management system.

\subsubsection{Bottom Sediment}

Bottom sediment accumulates small amounts of radioactive materials which may be present from time to time in the stream and, as a result, acts 
as an integrator of radtoactive matertal that was present in the water. It provides a historical record of radioactive materials in that surface water system. These samples are not routinely analyzed for chemical constituents.

Bottom sediment samples are collected annually from Sawmill creek above, at, and several locations below the point at which ANL discharges its treated waste water. Pertodically, sediment samples are collected from several on-site ponds and lagoons. Ten off-stte bottom sediment samples are collected each year, five in the spring and five in the fall, from remote locations to serve as controls. One gallon of sediment is collected from each location with a stainless steel scoop and transferred to a glass bottle.

At the time of sample collection, the date, time, and sample collector identification are recorded on sample labels affixed to the sample container. Upon return to the laboratory, the iriformation is transferred to the EMS system. Each sample is assigned a unique number which accompantes it through the process.

Each sample is dried for several days at $110^{\circ} \mathrm{C}$, ball milled, and steved through a No. 70 mesh screen. The material that does not pass the No. 70 screen is discarded. A 100 gram portion is taken for gamma-ray spectrometric measurement and other appropriate al iquots are used for specific radiochemical analysis.

\subsubsection{Soil}

Soil accumulates small amounts of particulate matter and serves as an integrator of the deposition of airborne releases of radioactive materials. Although it should not be used as the primary measurement system for air monitoring, in many cases, it may be the only available avenue if insufficient air sampling occurred at the time of an incident. The ANL program is designed to provide samples for analysis to determine if any changes in concentrations have occurred over the year. No analysis for chemical constituents is carried out on these samples. 
Each year ten soll samples are collected at the site perimeter (five spring and five fall) and ten samples at the remote locations (five spring and five fal1). Sampling sites are selected in reasonably level areas that represent undisturbed sol1. Two one-meter squares are marked off and sot1 samples are collected from the corners and center of each square. Samples are collected with a $10.4 \mathrm{~cm}$-diameter coring tool to a depth of $5 \mathrm{~cm}$. All ten cores are composited as a single sample. This procedure follows the ASTM Standard Method for Sampling Surface Soll for Radtonuclides, C-998.

At the time of sample collection, the date, time, and sample collector identification number are recorded on a preprinted sample label affixed to the sample contatner. Upon return to the laboratory, the information is transferred to the EMS system. Each sample is assigned a unique number which accompantes it through the process.

A $200 \mathrm{~g}$ portion of the soil is placed in a tube and heated. The soll water is collected, and analyzed for trittated water by liquid scintillation spectrometry. The entire sample is dried at $110^{\circ} \mathrm{C}$ for several days, ball milled, and sieved through a No. 70 mesh screen. The material that does not pass the No. 70 mesh screen is discarded. A $100 \mathrm{~g}$ portion is taken for gamma-ray spectrometric measurement and appropriate aliquots taken for radiochemical analysis. Because a known area of surface soll was collected, results are calculated in terms of concentration and deposition.

\subsubsection{Vegetation}

Grass samples are collected to determine the uptake of radionuclides from the soll by vegetation. This is done to monitor that part of the food chain pathway.

Ten perimeter and ten off-site grass samples are collected each year at the same locations as the soil samples. All the grass within one of the one-meter plots used for soil sampling is cut just above the soll surface and collected. 
At the time of sample collection, the date, time, and sample collector identification number are recorded on a preprinted sample label affixed to the sample contatner. Upon return to the laboratory, the information is transferred to the EMS system. Each sample is assigned a unique number which accompantes it through the process.

Grass samples are washed in water to remove surface dirt, dried at $110^{\circ} \mathrm{C}$ for several days, and ground. A $100 \mathrm{~g}$ al tquot is measured by gammaray spectrometry and appropriate al quots taken for radiochemical analysts.

\subsubsection{External Penetrating Radiation}

Measurements of direct penetrating radiation emanating from several sources within ANL are made using calcium fluoride thermoluminescent dosi. meter (TLD) chips. Each measurement is the average of four chips exposed in the same packet. A 11 calctum fluoride packets are shielded with $1 / 16$ inch copper fotl to reduce or el imtnate the beta and low-energy $x$-ray components. The response of the chips is determined with a U. S. National Institute of Standards and Technology (NIST) standard radfum-226 source.

Dosimeters are exposed at approximately 14 locations at the site perimeter and on the site and at five locations off the site. All dosimeters are changed quarteriy.

At the time of dosimeter collection, the date, time, and collector identification number are recorded on a preprinted label affixed to the container. Upon return to the laboratory, the information is transferrod to the EMS system. Each sample is assigned a unique number which accompanies it through the process.

The individual chips are read on an Eberline Model TLR-6 TLD reader. Control chips are read and their contribution subtracted from the values of the field chips. A set of chips irradiated with a radium-226 standard source is also read and these values are used to convert the individual fleld readings to dose. 


\section{ENVIRONMENTAL RADIOLOGICAL PROGRAM INFORMATION}

\subsection{Description of Monitoring Program}

The radioactivity of the environment around ANL was determined by measuring the concentrations of radioactive nuclides in naturally occurring materials and by measuring the external penetrating radiation dose. Sample collections and measurements were made at the site perimeter and off the site for comparative purposes. Some on-site results are also reported when they are useful in interpreting perimeter and off-site results.

Since radioactivity is primarily transported by air and water, the sample collection program concentrated on these media. In addition, samples of soil, plants, foodstuffs, and materials from the beds of 1 akes and streams also were analyzed. The program followed the guidance provided in the DOE Environmental ${ }^{4}$ and Effluent ${ }^{5}$ Survelllance Guides. About 1,830 samples were collected and approximately 4,400 analyses were performed. The results of radioactivity measurements are expressed in terms of picocuries per liter $(\mathrm{pCi} / \mathrm{L})$ for water and milk; femtocuries per cubic meter $\left(\mathrm{fCi} / \mathrm{m}^{3}\right)$ and attocuries per cubic meter $\left(\mathrm{aCi} / \mathrm{m}^{3}\right)$ for air; and picocuries per gram $(p C i / g)$, femtocuries per gram $(f C i / g)$, and/or nanocuries per square meter $\left(\mathrm{nCi} / \mathrm{m}^{2}\right)$ for soil, bottom sediment, and vegetation. Penetrating radiation measurements are reported in units of millirem per year (mrem/y) and population dose in man-rem. Other units are defined in the text.

The DOE has provided guidance ${ }^{6}$ for effective dose equivalent calculations for members of the public, based on ICRP-26 and ICRP-30.' Those procedures have been used in inis report. The methodology requires three components to be calculated: (1) the committed effective dose equivalent from all sources of ingestion, (2) the committed effective dose equivalent from inhalation, and (3) direct effective dose equivalent from external radiation. These three components are summed for comparison with the DOE effective dose equivalent limits for environmental exposure. The guidance requires that sufficient data on exposure to radionuclide sources be available to assure that at least $90 \%$ of the total committed effective dose equivalent is accounted for. The primary radiation dose limit for members 
of the public is $100 \mathrm{mrem} / \mathrm{y}$. The effective dose equivalents for members of the public from all routine DOE operations, natural background and medical exposures excluded, shall not exceed the values and shall be as low as reasonably achievable (ALAR $\Lambda$ ), or as far below the 1 imits as is practical. Routine DOE operations are normally planned operations, which exclude actual or potential accidental or unplanned releases.

The measured or calculated environmental radionuclide concentrations are converted to a 50-year committed effective dose equivalent with the use of the Committed Effective Dose Equivalent Factors (CEDE) ${ }^{8}$ and compared to the annual dose limits for uncontrolled areas. The CEDE are calculated from the DOE Derived Concentration Guides $(D C G)^{6}$ for members of the public from ingested water and inhalation resulting in a radiation dose of $100 \mathrm{mrem} / \mathrm{y}$. The numerical values of the CEDE used in this report are given in Section 4.7. Although the CEDEs apply only to concentrations above natural levels, the calculated dose is sometimes given in this report for radioactivities that are primarily of natural origin for comparison purposes. Such values are enclosed in parentheses to indicate this. Occasionally, other standards are used, and their sources are identified in the text.

\subsection{Air}

The radioactive content of particulate matter in the air was determined by collecting and analyzing air-filter samples. The sampling locations are shown in Figures 1.1 and 1.2. Separate collections were made for specific radiochemical analyses and for gross alpha, gross beta, and gamma-ray spectrometry. The latter measurements were made on samples collected continuously on laminated glass fiber filters (changed weekly) at 13 locations at the ANL site perimeter and at five off-site locations.

In the past, the perimeter air samplers were located within butldings, did not have flow control devices, and no particle size differentiation. Early in 1989, the ANL site was reviewed by a professional meteorologist, taking into account potential sources of airborne radiological emissions and local meteorology, and 13 perimeter locations were identified for air samplers. These locations are identified in Figure 1.1. New PM-10 air 
samplers were procured, electrical power was provided to each location, and the new PM-10 units were installed. During November 1989, the new and existing air sampling systems were both operated and an analysis of the measured radioactivity on the collected air filters indicated no statistically significant difference in the overall averages and side-by-side comparisons of paired samplers. At the end of December 1989, use of the original system was terminated and the new PM-10 system began exclusive operation in January 1990.

Samples were collected at the site perimeter to determine if a statistically significant difference exists between perimeter measurements and measurements made on samples collected at various off-site locations. The off-site samples establish the local background concentrations of naturallyoccurring or ubiquitous man-made radionuclides, such as from nuclear weapons testing fallout. Higher levels of radioactivity in the air measured at the site perimeter may indicate radioactivity releases from ANL, providing the perimeter samples are greater than the background samples by an amount greater than the relative error of the measurement. The relative error is a result of natural variation in background concentrations as well as sampling and measurement error. This relative error is typically $5 \%$ to $20 \%$ of the measurement value for most of the analyses, but approaches $100 \%$ at values near the detection limit of the instrument.

The total alpha and beta activities in the individual weekly samples are summarized in Table 4.1. These measurements were made in low-background gas-flow proportional counters, and the counting efficiencies used to convert counting rates to disintegration rates were those measured for radon decay products on filter paper. The average concentrations of gamma-ray emitters, as determined by gamma-ray spectrometry performed on composit. weekly samples, are given in Table 4.2. The gamma-ray detector is shielded germanium diode calibrated for each gamma-ray emitting nuclide measured.

The alpha activity, principally due to naturally-occurring nuclides, averaged the same as in the past several years and was in its normal range. The perimeter beta activity averaged $27 \mathrm{fCl} / \mathrm{m}^{3}$, which is the same as the 
TABLE 4.1

Total Alpha and Beta Activities in Air-Filter Samples, 1990"

(Concentrations in $\mathrm{fCi} / \mathrm{m}$ )

\begin{tabular}{|c|c|c|c|c|c|c|c|c|}
\hline Month & Location & $\begin{array}{l}\text { No. of } \\
\text { Samples }\end{array}$ & Avg. ${ }^{A l i}$ & $\begin{array}{l}\text { Ma Activity. } \\
\text { Min. }\end{array}$ & Max. & Avg. Beta & $\begin{array}{l}\text { Activity } \\
\text { Min. }\end{array}$ & Max. \\
\hline January & $\begin{array}{l}\text { Perimeter } \\
\text { Off-Site }\end{array}$ & $\begin{array}{l}51 \\
20\end{array}$ & $\begin{array}{l}2.0 \\
2.0\end{array}$ & $\begin{array}{l}1.1 \\
0.8\end{array}$ & $\begin{array}{l}5.1 \\
4.6\end{array}$ & $\begin{array}{l}31.9 \\
34.4\end{array}$ & $\begin{array}{l}16.6 \\
15.1\end{array}$ & $\begin{array}{l}47.5 \\
85.7\end{array}$ \\
\hline February & $\begin{array}{l}\text { Perimeter } \\
\text { Off-Site }\end{array}$ & $\begin{array}{l}28 \\
16\end{array}$ & $\begin{array}{l}1.8 \\
2.0\end{array}$ & $\begin{array}{l}1.2 \\
1.1\end{array}$ & $\begin{array}{l}2.5 \\
3.1\end{array}$ & $\begin{array}{l}27.3 \\
27.8\end{array}$ & $\begin{array}{l}19.8 \\
15.8\end{array}$ & $\begin{array}{l}33.2 \\
39.1\end{array}$ \\
\hline March & $\begin{array}{l}\text { Perimeter } \\
\text { Off-Site }\end{array}$ & $\begin{array}{l}51 \\
16\end{array}$ & $\begin{array}{l}1.9 \\
2.1\end{array}$ & $\begin{array}{l}0.8 \\
1.1\end{array}$ & $\begin{array}{l}3.2 \\
3.4\end{array}$ & $\begin{array}{l}25.1 \\
26.4\end{array}$ & $\begin{array}{l}10.1 \\
14.2\end{array}$ & $\begin{array}{l}40.2 \\
42.4\end{array}$ \\
\hline April & $\begin{array}{l}\text { Perimeter } \\
\text { Off-Site }\end{array}$ & $\begin{array}{l}46 \\
16\end{array}$ & $\begin{array}{l}2.0 \\
2.1\end{array}$ & $\begin{array}{l}0.8 \\
1.1\end{array}$ & $\begin{array}{l}3.1 \\
3.2\end{array}$ & $\begin{array}{l}23.9 \\
24.6\end{array}$ & $\begin{array}{l}13.0 \\
11.9\end{array}$ & $\begin{array}{l}46.6 \\
38.2\end{array}$ \\
\hline May & $\begin{array}{l}\text { Perimeter } \\
\text { Off-Site }\end{array}$ & $\begin{array}{l}44 \\
25\end{array}$ & $\begin{array}{l}1.7 \\
1.6\end{array}$ & $\begin{array}{l}0.8 \\
0.7\end{array}$ & $\begin{array}{l}3.3 \\
3.0\end{array}$ & $\begin{array}{l}19.8 \\
20.9\end{array}$ & $\begin{array}{r}11.0 \\
9.7\end{array}$ & $\begin{array}{l}27.2 \\
31.4\end{array}$ \\
\hline June & $\begin{array}{l}\text { Perimeter } \\
\text { Off-Site }\end{array}$ & $\begin{array}{l}31 \\
16\end{array}$ & $\begin{array}{l}1.3 \\
1.6\end{array}$ & $\begin{array}{l}0.5 \\
0.8\end{array}$ & $\begin{array}{l}1.9 \\
2.3\end{array}$ & $\begin{array}{l}18.4 \\
20.2\end{array}$ & $\begin{array}{r}9.7 \\
15.1\end{array}$ & $\begin{array}{l}24.1 \\
26.3\end{array}$ \\
\hline July & $\begin{array}{l}\text { Perimeter } \\
\text { Off-Site }\end{array}$ & $\begin{array}{l}38 \\
17\end{array}$ & $\begin{array}{l}1.4 \\
1.4\end{array}$ & $\begin{array}{l}0.8 \\
0.5\end{array}$ & $\begin{array}{l}2.2 \\
2.4\end{array}$ & $\begin{array}{l}21.3 \\
22.4\end{array}$ & $\begin{array}{r}16.5 \\
5.6\end{array}$ & $\begin{array}{l}24.7 \\
29.9\end{array}$ \\
\hline August & $\begin{array}{l}\text { Perimeter } \\
\text { Off-Site }\end{array}$ & $\begin{array}{l}43 \\
21\end{array}$ & $\begin{array}{l}1.8 \\
1.6\end{array}$ & $\begin{array}{l}0.9 \\
1.0\end{array}$ & $\begin{array}{l}3.7 \\
2.8\end{array}$ & $\begin{array}{l}25.4 \\
27.8\end{array}$ & $\begin{array}{l}10.8 \\
14.4\end{array}$ & $\begin{array}{l}39.6 \\
44.6\end{array}$ \\
\hline September & $\begin{array}{l}\text { Perimeter } \\
\text { Off-Site }\end{array}$ & $\begin{array}{l}28 \\
13\end{array}$ & $\begin{array}{l}2.1 \\
2.5\end{array}$ & $\begin{array}{l}1.1 \\
1.4\end{array}$ & $\begin{array}{l}3.6 \\
4.1\end{array}$ & $\begin{array}{l}31.2 \\
40.5\end{array}$ & $\begin{array}{l}19.3 \\
21.2\end{array}$ & $\begin{array}{l}46.2 \\
57.1\end{array}$ \\
\hline October & $\begin{array}{l}\text { Perimeter } \\
\text { Off-Site }\end{array}$ & $\begin{array}{l}62 \\
14\end{array}$ & $\begin{array}{l}2.2 \\
3.0\end{array}$ & $\begin{array}{l}0.8 \\
1.7\end{array}$ & $\begin{array}{l}4.3 \\
7.2\end{array}$ & $\begin{array}{l}32.3 \\
37.7\end{array}$ & $\begin{array}{l}19.5 \\
24.2\end{array}$ & $\begin{array}{l}57.2 \\
49.0\end{array}$ \\
\hline November & $\begin{array}{l}\text { Perimeter } \\
\text { Off-Site }\end{array}$ & $\begin{array}{l}41 \\
18\end{array}$ & $\begin{array}{l}2.1 \\
2.2\end{array}$ & $\begin{array}{l}0.1 \\
0.2\end{array}$ & $\begin{array}{l}6.7 \\
4.7\end{array}$ & $\begin{array}{l}30.6 \\
31.6\end{array}$ & $\begin{array}{l}2.3 \\
8.6\end{array}$ & $\begin{array}{l}50.6 \\
52.5\end{array}$ \\
\hline December & $\begin{array}{l}\text { Perimeter } \\
\text { Off-Site }\end{array}$ & $\begin{array}{l}38 \\
19\end{array}$ & $\begin{array}{l}1.5 \\
2.5\end{array}$ & $\begin{array}{l}1.1 \\
1.3\end{array}$ & $\begin{array}{l}2.1 \\
4.3\end{array}$ & $\begin{array}{l}31.4 \\
38.3\end{array}$ & $\begin{array}{l}25.9 \\
20.8\end{array}$ & $\begin{array}{l}41.2 \\
63.2\end{array}$ \\
\hline $\begin{array}{l}\text { Annual } \\
\text { Summary }\end{array}$ & $\begin{array}{l}\text { Perimeter } \\
\text { Off-Site }\end{array}$ & $\begin{array}{l}501 \\
2.11\end{array}$ & $\begin{array}{l}1.8 \pm 0.2 \\
2.0 \pm 0.3\end{array}$ & $\begin{array}{l}0.1 \\
0.2\end{array}$ & $\begin{array}{l}6.7 \\
7.2\end{array}$ & $\begin{array}{l}26.6 \pm 3.2 \\
29.4 \pm 4.5\end{array}$ & $\begin{array}{l}2.3 \\
5.6\end{array}$ & $\begin{array}{l}57.2 \\
85.7\end{array}$ \\
\hline
\end{tabular}


TABLE 4.2

Gamma-Ray Activity in Air-Filter Samples, 1990

(Concentrations in $\mathrm{fCi} / \mathrm{m}^{3}$ )

\begin{tabular}{|c|c|c|c|}
\hline Month & Location & Beryllium-7 & Lead-210 \\
\hline January & $\begin{array}{l}\text { Perimeter } \\
\text { Off-Site }\end{array}$ & $\begin{array}{l}42 \\
45\end{array}$ & $\begin{array}{l}36 \\
50\end{array}$ \\
\hline February & $\begin{array}{l}\text { Perimeter } \\
\text { Off-Site }\end{array}$ & $\begin{array}{l}79 \\
65\end{array}$ & $\begin{array}{l}43 \\
36\end{array}$ \\
\hline March & $\begin{array}{l}\text { Perimeter } \\
\text { Off-Site }\end{array}$ & $\begin{array}{l}69 \\
85\end{array}$ & $\begin{array}{l}23 \\
31\end{array}$ \\
\hline April & $\begin{array}{l}\text { Perimeter } \\
\text { Off-Site }\end{array}$ & $\begin{array}{l}71 \\
75\end{array}$ & $\begin{array}{l}23 \\
24\end{array}$ \\
\hline May & $\begin{array}{l}\text { Perimeter } \\
\text { Off-Site }\end{array}$ & $\begin{array}{l}73 \\
79\end{array}$ & $\begin{array}{l}20 \\
22\end{array}$ \\
\hline June & $\begin{array}{l}\text { Perimeter } \\
\text { Off-Site }\end{array}$ & $\begin{array}{l}84 \\
88\end{array}$ & $\begin{array}{l}17 \\
22\end{array}$ \\
\hline July & $\begin{array}{l}\text { Perimeter } \\
\text { Off-Site }\end{array}$ & $\begin{array}{l}74 \\
81\end{array}$ & $\begin{array}{l}22 \\
24\end{array}$ \\
\hline August & $\begin{array}{l}\text { Perimeter } \\
\text { Off-Site }\end{array}$ & $\begin{array}{l}68 \\
90\end{array}$ & $\begin{array}{l}30 \\
40\end{array}$ \\
\hline September & $\begin{array}{l}\text { Perimeter } \\
\text { Off-Site }\end{array}$ & $\begin{array}{l}81 \\
88\end{array}$ & $\begin{array}{l}48 \\
55\end{array}$ \\
\hline October & $\begin{array}{l}\text { Perimeter } \\
\text { Off-Site }\end{array}$ & $\begin{array}{l}56 \\
69\end{array}$ & $\begin{array}{l}32 \\
40\end{array}$ \\
\hline November & $\begin{array}{l}\text { Perimeter } \\
\text { Off-Site }\end{array}$ & $\begin{array}{l}62 \\
65\end{array}$ & $\begin{array}{l}44 \\
50\end{array}$ \\
\hline December & $\begin{array}{l}\text { Perimeter } \\
\text { Off-Site }\end{array}$ & $\begin{array}{l}45 \\
43\end{array}$ & $\begin{array}{l}38 \\
5 y\end{array}$ \\
\hline $\begin{array}{l}\text { Annual } \\
\text { Summary }\end{array}$ & $\begin{array}{l}\text { Perimeter } \\
\text { Off-Site }\end{array}$ & $\begin{array}{l}67 \pm 9 \\
73 \pm 10\end{array}$ & $\begin{array}{l}31 \pm 7 \\
38 \pm 9\end{array}$ \\
\hline Dose (mrem) & $\begin{array}{l}\text { Perimeter } \\
\text { off-Site }\end{array}$ & $\begin{array}{l}(0.00017) \\
(0.00018)\end{array}$ & $\begin{array}{l}(3.47) \\
(4.20)\end{array}$ \\
\hline
\end{tabular}


average value for the past five years. The gamma-ray emitters listed in Table 4.2 are those that have been present in the air for the past few years and are of natural origin. The beryllium-7 exhibits an increase in concentration in the spring, indicating its stratospheric origin. The lead-210 in air is due to the radioactive decay of gaseous radon-222 and is similar to last year. No airborne radionuclides from the accident at the Soviet nuclear power facility near Chernobyl were measurable in 1990.

The annual average alpha and beta activities since 1985 are displayed in Figure 4.1. The elevated beta activity in 1986 was due to fallout from the Chernobyl incident. If the radionuclides attributed to the Chernobyl incident are subtracted from the annual average of $40 \mathrm{fCi} / \mathrm{m}^{3}$. the

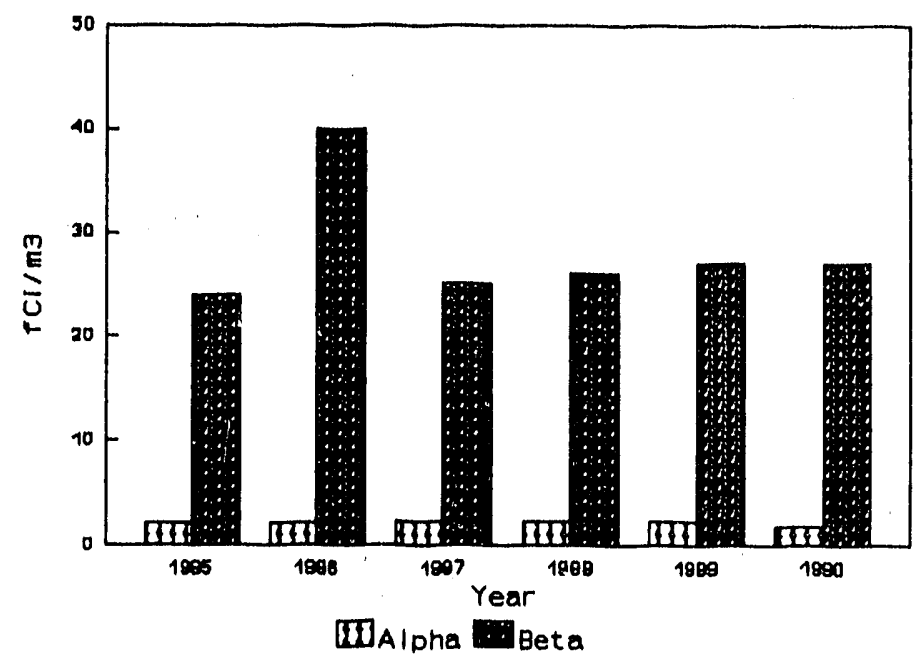

Figure 4.1 Comparison of Total Alpha and Beta Activities in Perimeter AirFilter Samples

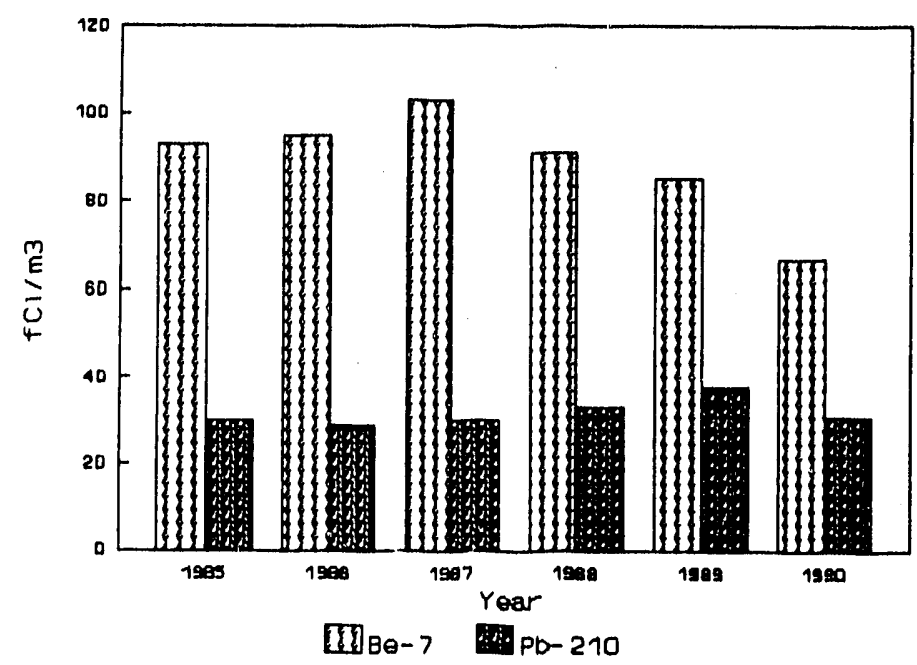

Figure 4.2 Comparison of Gamma-Ray Activity in Air-Filter Samples net would be $27 \mathrm{fCi} / \mathrm{m}^{3}$, very similar to the averages of the other years. Figure 4.2 presents the annual average concentrations of the two major gamma-ray-emitting radionuclides in air. The beryllium-7 is about $30 \%$ lower than in past years.

Samples for radiochemi cal analyses were collected at perimeter locations $12 \mathrm{~N}$ 
and 71 (Figure 1.1) and off the site in Downers Grove (Figure 1.2). The sampler at location 7 I was removed in August due to building reconstruction and by the end of the year had not been relocated. Collections were made on polystyrene filters. The total air volume filtered for the monthly samples was about $20,000 \mathrm{~m}^{3}\left(700,000 \mathrm{ft}^{3}\right)$. Samples were ignited at $600^{\circ} \mathrm{C}\left(1080^{\circ} \mathrm{F}\right)$ to remove organic matter and were prepared for analysis by vigorous treatment with hot hydrochloric, hydrofluoric, and nitric acids.

Plutonium and thorium were separated on an anion exchange column, and the uranium was extracted from the column effluent. Following the extraction, the aqueous phase was analyzed for radiostrontium by a standard radiochemical procedure. The separated plutonium, thorium, and uranium fractions were electrodeposited and measured by alpha spectrometry. The chemical recoveries were monitored by adding known amounts of plutonium-242, thorium229, and uranium-236 tracers prior to ignition. Since alpha spectrometry cannot distinguish between plutonium-239 and plutonium-240, it should be understood that when plutonium-239 is mentioned in this report, the alpha activity due to the plutonium-240 isotope is also included. The results are given in Table 4.3 .

The strontium-90 concentrations have decreased over the past several years so that during 1990 most results were less than the detection limit of $10 \mathrm{aCi} / \mathrm{m}^{3}$. Strontium-89 was not observed above the detection $1 \mathrm{imit}$ of 100 $\mathrm{aCi} / \mathrm{m}^{3}$. The plutonium-239 concentrations were about a factor of two lower, both on and off the site than last year, and similar to 1988 results.

The thorium and uranium concentrations are in the same range found in the past and are considered to be of natural origin. The amounts of thorium and uranium in a sample were proportional to the mass of inorganic material collected on the filter paper. The bulk of these elements in the air was due to resuspension of soil. In contrast, the amount of plutonium in the air samples contributed by soil ranged from about $3 \%$ to $45 \%$ and averaged $14 \%$ of the total plutonium in the samples. This assumes that the resuspended soil has the same plutonium concentration as the first centimeter of soil on the ground. The remainder of the plutonium-239 is due to worldwide fallout. 
TABLE 4.3

Strontium, Thorium, Uranium, and Plutonium Concentrations

in Air-filter Samples, 1990

(Concentrations in Attocuries/m ${ }^{3}$ )

\begin{tabular}{|c|c|c|c|c|c|c|c|c|}
\hline Month & Location* & Stront ium- 90 & Thor ium-228 & Thorium-230 & Thor ium-232 & Uranium-234 & Uranium-238 & Plutonium-239 \\
\hline \multirow[t]{3}{*}{ January } & 71 & $<10$ & $10 \pm 2$ & $12 \pm 2$ & $5 \pm 1$ & $29 \pm 3$ & $24 \pm 3$ & $1.1 \pm 0.5$ \\
\hline & $12 N$ & $<10$ & $7 \pm 2$ & $13 \pm 2$ & $5 \pm 1$ & $19 \pm 2$ & $15 \pm 1$ & $1.6 \pm 0.5$ \\
\hline & off-site & $<10$ & $18 \pm 3$ & $33 \pm 4$ & $4 \pm 1$ & $18 \pm 6$ & $8 \pm 4$ & $1.3 \pm 0.5$ \\
\hline \multirow[t]{3}{*}{ February } & 71 & $<10$ & $12 \pm 1$ & $9 \pm 1$ & $4 \pm 1$ & $20 \pm 2$ & $20 \pm 2$ & $1.2 \pm 0.4$ \\
\hline & $12 N$ & $<10$ & $9 \pm 2$ & $12 \pm 2$ & $5 \pm 1$ & $18 \pm 4$ & $24 \pm 4$ & $1.4 \pm 0.4$ \\
\hline & off.site & $10 \pm 5$ & $46 \pm 6$ & $74 \pm 7$ & $30 \pm 4$ & $20 \pm 1$ & $22 \pm 1$ & $1.3 \pm 0.5$ \\
\hline \multirow[t]{3}{*}{ March } & 71 & $<10$ & $2 \pm 1$ & $8 \pm 1$ & $3 \pm 1$ & $15 \pm 1$ & $11 \pm 1$ & $0.8 \pm 0.4$ \\
\hline & $12 N$ & $<10$ & $5 \pm 2$ & $7 \pm 1$ & $3 \pm 1$ & $14 \pm 1$ & $10 \pm 1$ & $1.2 \pm 0.4$ \\
\hline & off-site & $<10$ & $5 \pm 3$ & $9 \pm 2$ & $3 \pm 1$ & $20 \pm 2$ & $8 \pm 1$ & $1.8 \pm 0.7$ \\
\hline \multirow[t]{3}{*}{ April } & 71 & $<10$ & $4 \pm 2$ & $14 \pm 2$ & $6 \pm 1$ & $10 \pm 2$ & $8 \pm 1$ & $0.7 \pm 0.3$ \\
\hline & $12 N$ & $18 \pm 10$ & $6 \pm 3$ & $17 \pm 2$ & $7 \pm 2$ & $18 \pm 2$ & $17 \pm 2$ & $1.2 \pm 0.4$ \\
\hline & off-site & $<10$ & $4 \pm 2$ & $9 \pm 1$ & $2 \pm 1$ & $7 \pm 1$ & $6 \pm 1$ & $1.0 \pm 0.4$ \\
\hline \multirow[t]{3}{*}{ May } & 71 & $<10$ & $9 \pm 2$ & $12 \pm 2$ & $6 \pm 1$ & $11 \pm 2$ & $10 \pm 2$ & $0.9 \pm 0.3$ \\
\hline & $12 N$ & $<10$ & $8 \pm 3$ & $15 \pm 2$ & $8 \pm 2$ & $17 \pm 2$ & $14 \pm 2$ & $1.8 \pm 0.5$ \\
\hline & off-site & $<10$ & $10 \pm 2$ & $6 \pm 1$ & $3 \pm 1$ & $7 \pm 2$ & $6 \pm 2$ & $1.1 \pm 0.4$ \\
\hline \multirow[t]{3}{*}{ June } & 71 & $<10$ & $30 \pm 3$ & $25 \pm 3$ & $18 \pm 2$ & $45 \pm 6$ & $39 \pm 5$ & $1.3 \pm 0.4$ \\
\hline & $12 N$ & $<10$ & $6 \pm 2$ & $13 \pm 2$ & $8 \pm 1$ & $19 \pm 4$ & $18 \pm 4$ & $1.6 \pm 0.5$ \\
\hline & off-site & $<10$ & $7 \pm 2$ & $9 \pm 1$ & $5 \pm 1$ & $15 \pm 3$ & $13 \pm 3$ & $1.3 \pm 0.4$ \\
\hline \multirow[t]{3}{*}{ July } & 71 & $<10$ & $16 \pm 2$ & $10 \pm 1$ & $4 \pm 1$ & $19 \pm 4$ & $30 \pm 5$ & $0.9 \pm 0.4$ \\
\hline & $12 N$ & $<10$ & $13 \pm 2$ & $9 \pm 2$ & $4 \pm 1$ & $19 \pm 4$ & $29 \pm 5$ & $1.3 \pm 0.6$ \\
\hline & off-site & $<10$ & $10 \pm 1$ & $16 \pm 1$ & $3 \pm 1$ & $13 \pm 2$ & $22 \pm 3$ & $1.2 \pm 0.4$ \\
\hline \multirow[t]{3}{*}{ August } & 71 & - & - & - & - & - & . & . \\
\hline & $12 N$ & $<10$ & $27 \pm 3$ & $8 \pm 1$ & $4 \pm 1$ & $8 \pm 2$ & $11 \pm 2$ & $1.1 \pm 0.4$ \\
\hline & off-site & $14 \pm 7$ & $21 \pm 3$ & $9 \pm 2$ & $2 \pm 1$ & $8 \pm 2$ & $18 \pm 3$ & $1.3 \pm 0.5$ \\
\hline \multirow[t]{3}{*}{ September } & 71 & $\cdot$ & $\cdot$ & $\cdot$ & $\cdot$ & $\cdot$ & - & - \\
\hline & $12 \mathrm{~N}$ & $<10$ & $20 \pm 1$ & $26 \pm 2$ & $4 \pm 1$ & $13 \pm 1$ & $26 \pm 2$ & $1.1 \pm 0.3$ \\
\hline & off.site & $<10$ & $13 \pm 2$ & $6 \pm 1$ & $3 \pm 1$ & $20 \pm 3$ & $18 \pm 3$ & $1.1 \pm 0.4$ \\
\hline \multirow[t]{3}{*}{ October } & 71 & $\cdot$ & $\cdot$ & $\cdot$ & $\cdot$ & $\cdot$ & - & . \\
\hline & $12 \mathrm{~N}$ & $<10$ & $33 \pm 3$ & $13 \pm 2$ & $5 \pm 1$ & $16 \pm 3$ & $34 \pm 4$ & $0.9 \pm 0.3$ \\
\hline & off-site & $12 \pm 8$ & $33 \pm 3$ & $34 \pm 2$ & $2 \pm 1$ & $12 \pm 4$ & $12 \pm 3$ & $2.0 \pm 0.7$ \\
\hline \multirow[t]{3}{*}{ November } & 71 & $\cdot$ & $\cdot$ & $\cdot$ & . & $\cdot$ & - & . \\
\hline & $12 N$ & $<10$ & $22 \pm 3$ & $70 \pm 6$ & $9 \pm 2$ & $14 \pm 2$ & $18 \pm 2$ & $0.7 \pm 0.3$ \\
\hline & off-site & $<10$ & $10 \pm 1$ & $4 \pm 1$ & $1 \pm 0$ & $6 \pm 1$ & $5 \pm 1$ & $0.7 \pm 0.3$ \\
\hline \multirow[t]{3}{*}{ December } & 71 & $\cdot$ & $\cdot$ & - & $\cdot$ & - & - & - \\
\hline & $12 \mathrm{~N}$ & $<10$ & $42 \pm 3$ & $5 \pm 1$ & $4 \pm 1$ & $9 \pm 2$ & $12 \pm 2$ & $1.4 \pm 0.5$ \\
\hline & off-site & $<10$ & $25 \pm 2$ & $8 \pm 1$ & $2 \pm 1$ & $23 \pm 2$ & $48 \pm 3$ & $1.1 \pm 0.4$ \\
\hline Annual & 71 & $<10$ & $12 \pm 23$ & $13 \pm 14$ & $6 \pm 12$ & $21 \pm 30$ & $20 \pm 28$ & $1.0 \pm 0.5$ \\
\hline \multirow[t]{2}{*}{ Summary } & $12 \mathrm{~N}$ & $<10$ & $16 \pm 27$ & $17 \pm 39$ & $5 \pm 4$ & $15 \pm 8$ & $19 \pm 17$ & $1.3 \pm 0.7$ \\
\hline & off-site & $<10$ & $17 \pm 28$ & $18 \pm 45$ & $5 \pm 17$ & $14 \pm 13$ & $15 \pm 26$ & $1.3 \pm 0.8$ \\
\hline \multirow[t]{3}{*}{ Dose (mrem) } & 71 & $<(0.00001)$ & $(0.0301)$ & $(0.0260)$ & $(0.065)$ & $(0.00107)$ & $(0.00102)$ & $(0.0024)$ \\
\hline & $12 \mathrm{~N}$ & $<(0.00006)$ & $(0.0410)$ & $(0.0346)$ & $(0.054)$ & $(0.00077)$ & $(0.00095)$ & $(0.0032)$ \\
\hline & Off.site & $<(0.00006)$ & $(0.0422)$ & $(0.0363)$ & $(0.050)$ & $(0.00070)$ & $(0.00077)$ & $(0.0032)$ \\
\hline
\end{tabular}

* Perimeter locations are given in terms of the grid coordinates in figure 1.1 
The major airborne effluents released at ANL during 1990 are listed by location in Table 4.4 and the annual releases of the major sources since 1986 are illustrated in

Figure 4.3. The radon-220 released from Building 200 is due to radioactive contamination from the "proofof-breeding" program and from nuclear medicine studies. Even though the CP-5 reactor ceased operations in 1977, hydrogen-3 continues to be emitted from Building 330. The hydrogen3 emitted from Building 212 is from tritium recovery studies. In addition to the nuclides listed in Table

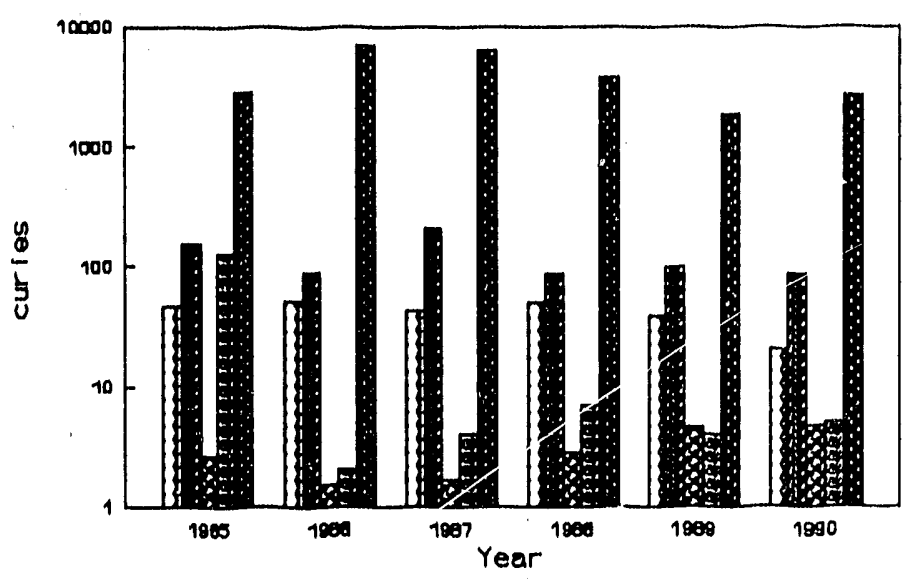

WIYDPOGER-3 - CARBON-11 $_{\text {ARGON-41 }}$ DKRYPTON-65 RADON-220

4.4, several other fission products also were released in millicurie or smaller amounts. The quantities listed in Table 4.4 were measured by online stack monitors in the exhaust systems of the buildings, except for Building 350 .

Tritium concentrations in air were measured because experiments in Building 212 and residual materials in Building 330 (CP-5) could release tritiated water vapor. Samples were collected at perimeter locations $8 \mathrm{~F}$ (at the southwestern corner of the site) and $12 \mathrm{~N}$ (on the eastern perimeter of the site), and off the site in Woodridge. The water vapor was collected by adsorption on silica gel, and the tritium concentration was measured by counting the desorbed water in a liquid scintillation spectrometer. The results are given in Table 4.5. Based on the data in Table 4.4, the principal sources of the tritiated water vapor should be from Building 212, location 12I, and Building 330, location $9 H$ (CP-5). Because the winds are usualiy from the west to south quadrant, the tritium concentrations should be higher at equal distances east and north of the release points. However, the concentrations at $8 \mathrm{~F}$ were higher than at $12 \mathrm{~N}$, because the $8 \mathrm{~F}$ location is 
TABLE 4.4

Summary of Airborne Radioactive Emissions from ANL Facilities, 1990

\begin{tabular}{|c|c|c|c|}
\hline Building & Nuclide & Half-Life & $\begin{array}{c}\text { Amount } \\
\text { Released } \\
\text { (Curies/y) }\end{array}$ \\
\hline 200 & $\begin{array}{l}\text { Radon-220 } \\
\text { Radon-222 }\end{array}$ & $\begin{array}{l}56 \mathrm{~s} \\
3.82 \mathrm{~d}\end{array}$ & $\begin{array}{l}2606 \\
0.09\end{array}$ \\
\hline 202 (JANUS) & Argon-41 & $1.8 \mathrm{~h}$ & 1.23 \\
\hline 205 & Hydrogen-3 (HTO) & $12.3 y$ & 0.16 \\
\hline 211 & $\begin{array}{l}\text { Carbon-11 } \\
\text { Nitrogen-13 } \\
\text { Oxygen-15 } \\
\text { Fluorine-18 } \\
\text { Argon-41 }\end{array}$ & $\begin{array}{r}20 \mathrm{~m} \\
10 \mathrm{~m} \\
122 \mathrm{~s} \\
110 \mathrm{~m} \\
1.8 \mathrm{~h}\end{array}$ & $\begin{array}{l}0.60 \\
0.96 \\
5.79 \\
0.02 \\
0.04\end{array}$ \\
\hline 212 & $\begin{array}{l}\text { Hydrogen-3 (HTO) } \\
\text { Hydrogen-3 (HT) } \\
\text { Krypton-85 } \\
\text { Ant imony-125 } \\
\text { Radon-220 }\end{array}$ & $\begin{array}{l}12.3 \mathrm{y} \\
12.3 \mathrm{y} \\
10.7 \mathrm{y} \\
2.71 \mathrm{y} \\
56 \mathrm{~s}\end{array}$ & $\begin{array}{l}2.85 \\
5.25 \\
5.18 \\
0.00014 \\
0.052\end{array}$ \\
\hline $330(C P-5)$ & Hydrogen-3 (HTO) & $12.3 \mathrm{y}$ & 11.7 \\
\hline 375 (IPNS) & $\begin{array}{l}\text { Carbon-11 } \\
\text { Argon-41 }\end{array}$ & $\begin{array}{r}20 \mathrm{~m} \\
1.8 \mathrm{~h}\end{array}$ & $\begin{array}{r}86.1 \\
3.5\end{array}$ \\
\hline $350(\mathrm{NBL})$ & $\begin{array}{l}\text { Uranium-234 } \\
\text { Uranium-238 } \\
\text { Plutonium-238 } \\
\text { Plutonium-239 } \\
\text { Plutonium-240 } \\
\text { Plutonium-241 } \\
\text { Plutonium-242 } \\
\text { Neptunium-237 } \\
\text { Americium-241 } \\
\text { Americium-243 }\end{array}$ & $\begin{array}{c}2.4 \times 10^{5} \mathrm{y} \\
4.5 \times 10^{9} \mathrm{y} \\
87.7 \mathrm{y} \\
2.4 \times 10^{4} \\
6.6 \times 10^{4} \\
14.4 \mathrm{y} \\
3.76 \times 10^{5} \\
2.14 \times 10^{6} \\
432 \mathrm{y} \\
7370 \mathrm{y}\end{array}$ & $\begin{array}{r}4.2 \times 10^{-6} \\
4.2 \times 10^{-6} \\
3.06 \times 10^{-5} \\
3.35 \times 10^{-5} \\
8.08 \times 10^{-6} \\
1.91 \times 10^{-3} \\
1.64 \times 10^{-8} \\
1.42 \times 10^{-8} \\
3.09 \times 10^{-5} \\
2.00 \times 10^{-7}\end{array}$ \\
\hline
\end{tabular}


TABLE 4.5

Tritiated Water Vapor in Air, 1990 (concentrations in $\mathrm{pCi} / \mathrm{m}^{3}$ )

\begin{tabular}{|c|c|c|c|c|c|}
\hline Month & Location* & $\begin{array}{l}\text { No. of } \\
\text { Samples }\end{array}$ & Avg. & Min. & Max. \\
\hline January & $\begin{array}{c}8 F \\
12 N \\
\text { off-Site }\end{array}$ & $\begin{array}{l}9 \\
9 \\
2\end{array}$ & $\begin{array}{r}<0.10 \\
0.10 \\
<0.10\end{array}$ & $\begin{array}{l}<0.10 \\
<0.10 \\
<0.10\end{array}$ & $\begin{array}{r}0.75 \\
0.65 \\
<0.10\end{array}$ \\
\hline February & $\begin{array}{c}8 F \\
12 N \\
\text { off-Site }\end{array}$ & $\begin{array}{l}8 \\
8 \\
2\end{array}$ & $\begin{array}{l}0.27 \\
0.24 \\
0.26\end{array}$ & $\begin{array}{l}<0.10 \\
<0.10 \\
<0.10\end{array}$ & $\begin{array}{l}0.44 \\
0.41 \\
0.43\end{array}$ \\
\hline March & $\begin{array}{c}8 \mathrm{~F} \\
12 \mathrm{~N} \\
\text { off-Site }\end{array}$ & $\begin{array}{l}8 \\
8 \\
2\end{array}$ & $\begin{array}{l}0.34 \\
0.22 \\
0.24\end{array}$ & $\begin{array}{r}<0.10 \\
<0.10 \\
0.19\end{array}$ & $\begin{array}{l}0.93 \\
0.58 \\
0.29\end{array}$ \\
\hline April & $\begin{array}{c}8 \mathrm{~F} \\
12 \mathrm{~N} \\
\text { Off-Site }\end{array}$ & $\begin{array}{l}9 \\
9 \\
2\end{array}$ & $\begin{array}{l}<0.10 \\
<0.10 \\
<0.10\end{array}$ & $\begin{array}{l}<0.10 \\
<0.10 \\
<0.10\end{array}$ & $\begin{array}{l}0.39 \\
1.12 \\
0.26\end{array}$ \\
\hline May & $\begin{array}{c}8 F \\
12 N \\
\text { off-Site }\end{array}$ & $\begin{array}{l}9 \\
9 \\
2\end{array}$ & $\begin{array}{r}0.18 \\
<0.10 \\
0.23\end{array}$ & $\begin{array}{l}<0.10 \\
<0.10 \\
<0.10\end{array}$ & $\begin{array}{l}1.11 \\
0.54 \\
0.37\end{array}$ \\
\hline June & $\begin{array}{c}8 F \\
12 N \\
\text { off-Site }\end{array}$ & $\begin{array}{l}8 \\
8 \\
2\end{array}$ & $\begin{array}{l}<0.10 \\
<0.10 \\
<0.10\end{array}$ & $\begin{array}{l}<0.10 \\
<0.10 \\
<0.10\end{array}$ & $\begin{array}{r}1.46 \\
0.59 \\
<0.10\end{array}$ \\
\hline Juty & $\begin{array}{c}8 F \\
12 N \\
\text { off-Site }\end{array}$ & $\begin{array}{l}9 \\
9 \\
2\end{array}$ & $\begin{array}{r}0.59 \\
<0.10 \\
<0.10\end{array}$ & $\begin{array}{l}<0.10 \\
<0.10 \\
<0.10\end{array}$ & $\begin{array}{r}2.53 \\
0.47 \\
<0.10\end{array}$ \\
\hline August & $\begin{array}{c}8 F \\
12 N \\
\text { off-Site }\end{array}$ & $\begin{array}{l}9 \\
9 \\
2\end{array}$ & $\begin{array}{l}1.07 \\
0.74 \\
1.92\end{array}$ & $\begin{array}{r}0.10 \\
0.10 \\
1.62\end{array}$ & $\begin{array}{l}2.33 \\
1.25 \\
2.22\end{array}$ \\
\hline September & $\begin{array}{c}8 F \\
12 N \\
\text { off-Site }\end{array}$ & $\begin{array}{l}5 \\
9 \\
2\end{array}$ & $\begin{array}{l}0.97 \\
0.57 \\
0.82\end{array}$ & $\begin{array}{l}<0.10 \\
<0.10 \\
0.14\end{array}$ & $\begin{array}{l}2.13 \\
1.59 \\
1.49\end{array}$ \\
\hline October & $\begin{array}{c}8 F \\
12 N \\
\text { off-Site }\end{array}$ & $\begin{array}{l}9 \\
9 \\
2\end{array}$ & $\begin{array}{l}0.54 \\
0.26 \\
0.52\end{array}$ & $\begin{array}{l}<0.10 \\
<0.10 \\
0.42\end{array}$ & $\begin{array}{l}1.92 \\
1.16 \\
0.63\end{array}$ \\
\hline November & $\begin{array}{c}8 F \\
12 N \\
\text { off-Site }\end{array}$ & $\begin{array}{l}8 \\
8 \\
2\end{array}$ & $\begin{array}{r}0.13 \\
0.38 \\
<0.10\end{array}$ & $\begin{array}{l}<0.10 \\
<0.10 \\
<0.10\end{array}$ & $\begin{array}{l}1.30 \\
2.58 \\
0.13\end{array}$ \\
\hline December & $\begin{array}{c}8 F \\
12 N \\
\text { off-Site }\end{array}$ & $\begin{array}{l}6 \\
6 \\
2\end{array}$ & $\begin{array}{l}0.27 \\
0.10 \\
0.14\end{array}$ & $\begin{array}{l}<0.10 \\
<0.10 \\
<0.10\end{array}$ & $\begin{array}{l}1.49 \\
0.35 \\
0.30\end{array}$ \\
\hline $\begin{array}{l}\text { Annual } \\
\text { Summary }\end{array}$ & $\begin{array}{c}8 F \\
12 N \\
\text { off-Site }\end{array}$ & $\begin{array}{r}97 \\
101 \\
24\end{array}$ & $\begin{array}{l}0.33 \\
0.18 \\
0.21\end{array}$ & $\begin{array}{l}<0.10 \\
<0.10 \\
<0.10\end{array}$ & $\begin{array}{l}2.53 \\
2.58 \\
2.22\end{array}$ \\
\hline Dose (mrem) & $\begin{array}{c}8 \mathrm{~F} \\
12 \mathrm{~N} \\
\text { Off-Site }\end{array}$ & - & $\begin{array}{l}0.00033 \\
0.00018 \\
0.00021\end{array}$ & $\begin{array}{l}<0.00010 \\
<0.00010 \\
<0.00010\end{array}$ & $\begin{array}{l}0.00253 \\
0.00258 \\
0.00222\end{array}$ \\
\hline
\end{tabular}


closer to the principal source $(C P-5)$. At all sampling locations, the doses were very low compared with applicable standards. This sampling system was terminated at the end of $\mathrm{Cr} 1990$ since the samples did not provide sufficient sensitivity for measuring tritium in air and tritium stack monitors were installed at the CP-5 exhaust.

\subsection{Surface Water}

All surface water samples collected in the monitoring program were acidified to $0.1 \mathrm{~N}$ with $\mathrm{HNO}_{3}$ and filtered immediately after collection. Total nonvolatile alpha and beta activities were determined by counting the residue remaining after evaporation of the water and then applying counting efficiency corrections determined for uranium-233 (for alpha activity) and thallium-204 (for beta activity) to obtain disintegration rates. Hydrogen-3 was measured from a separate aliquot, and this activity does not appear in the results for total nonvolatile beta activity. Uranium was measured with a laser fluorometer, and the results were calculated in terms of activity, with the assumption that the isotopic composition was that of natural uranium. Analyses for other radionuclides were performed by specific radiochemical separations followed by appropriate counting. One-liter aliquots were used for all analyses except for hydrogen-3 and the transuranium nuclides. Hydrogen-3 analyses were performed by liquid scintillation counting of $9 \mathrm{~mL}$ of a distilled sample in a gel medium. Analyses for transuranium nuclides were performed on 10-1iter samples with chemical separation methods followed by alpha spectrometry. ${ }^{9,10}$ Plutonium-236 was used to determine the yields of plutonium and neptunium, which were separated from the sample together. A group separation of a fraction containing the transplutonium elements was monitored for recovery with americium-243 tracer.

Argonne wastewater is discharged into Sawmill creek, which runs through the ANL grounds, drains surface water from much of the site, and flows into the Des Plaines River about $500 \mathrm{~m}(0.3 \mathrm{mi})$ downstream from the ANL wastewater outfal1. Sawmill Creek was sampled upstream from the ANL site and downstream from the wastewater outfall to determine if radioactivity was added to the stream by ANL wastewater or surface drainage. The sampling 
locations are shown in Figure 1.1. Below the wastewater outfall, daily samples were collected by grab sampling. Equal portions of the daily samples collected each week were combined and analyzed to obtain an average weekly concentration. Upstream of the site, samples were collected once a month and were analyzed for the same radionuclides measured in the belowoutfall samples.

Annual summaries of the results obtained for Sawmill Creek are given in Table 4.6. Comparison of the results and $95 \%$ confidence levels of the averages for the two samp?ing locations shows that the nuclides found in the creek water that can be attributed to ANL operations were strontium-90, neptunium-237, plutonium-239, americium-241, and occasionally hydrogen-3, cesium-137, plutonium-238, curium-242 and/or californium-252, and curium-244 and/or californium-249. The percentage of individual samples containing activity attributable to ANL was $27 \%$ for hydrogen-3, $75 \%$ for strontium-90, $18 \%$ for cesium-137, 65\% for neptunium-23\%, $100 \%$ for plutonium-239, and $96 \%$ for americium-241. The concentrations of all these nuclides were low and a small fraction of the allowed DOE limits. This demonstrates compliance with DOE Order 5400.5 for use of Best Available Technology (BAT) for release of liquid effluents.

At location 7M, below the ANL outfall, the annual average concentrations of most measured radionuclides were similar to the 1989 averages. All the annual averages were well below the applicable standards. The annual total radioactive effluent discharged to the creek in ANL wastewater can be estimated from the average net concentrations and the volume of water carried by the creek. These totals are collected in Table 4.7.

Because Sawmill Creek empties into the Des Plaines River, which in turn flows into the Illinois River, data on the radioactivity in the two rivers are important in assessing the contribution of ANL wastewater to environmental radioactivity. The Des Plaines River was sampled twice a month below, and once a month above, the mouth of Sawmill creek to determine if the radioactivity in the creek had any effect on the radioactivity in the river. 


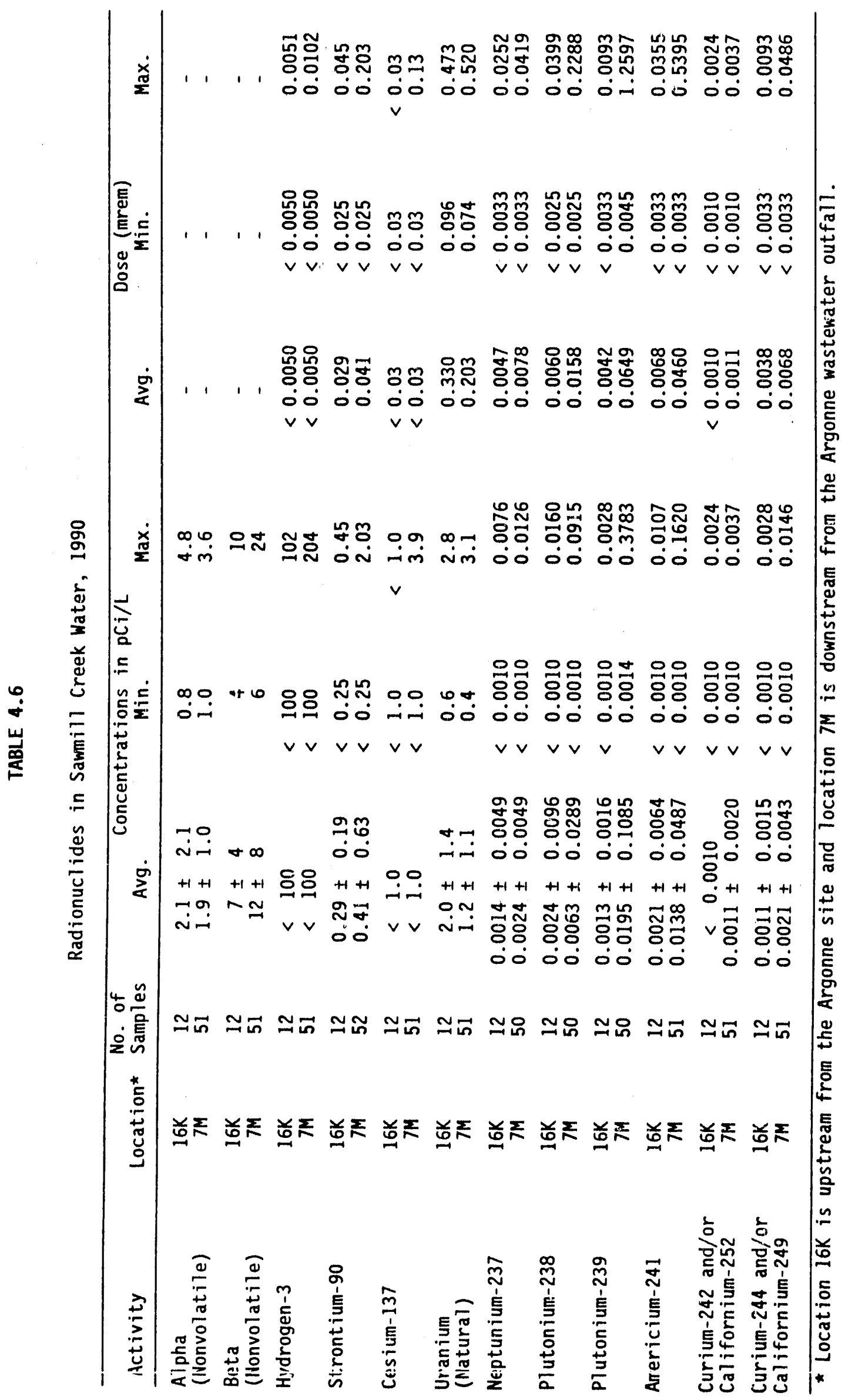


TABLE 4.7

Total Radioactivity Released to Sawmill Creek, 1990

\begin{tabular}{llc}
\hline Radionuclide & Released $(C i)$ & Percent \\
\hline Hydrogen-3 & 0.350 & 98.6 \\
Strontium-90 & $1.4 \times 10^{-3}$ & 0.4 \\
Cesium-137 & $3.0 \times 10^{-3}$ & 0.8 \\
Neptunium-237 & $7.4 \times 10^{-6}$ & 0.1 \\
Plutonium-239 & $2.0 \times 10^{-4}$ & 0.06 \\
Americium-241 & $1.3 \times 10^{-4}$ & 0.04 \\
Total & 0.355 & \\
\hline
\end{tabular}

Table 4.8 presents annual summaries of the results obtained for these two locations. The average nonvolatile alpha, beta, and uranium concentrations in the river were very similar to past averages and remained in the normal range. Results were quite similar above and below the creek for all radionuclides, because the activity in Sawmill creek was reduced by dilution to the point that it was not detectable in the Des Plaines River. The average nonvolatile alpha and beta activities, $1.8 \mathrm{pCi} / \mathrm{L}$ and $8.1 \mathrm{pCi} / \mathrm{L}$, respectively, of 22 off-site surface water samples collected in 1990 were similar to the levels found in previous years. The hydrogen-3 concentration in these surface water samples averaged $74 \mathrm{pCi} / \mathrm{L}$.

The radioactivity levels in samples of Illinois River water, shown in Table 4.9, were similar to those found previously at these same locations. No radioactivity originating at ANL could be detected in the Des Plaines or Illinois rivers.

\subsection{Soil, Grass, and Bottom Sediment}

The radioactive content of soil, grass, and bottom sediment was measured at the site perimeter and off the site. The purpose of the offsite sampling was to measure deposition for comparison with perimeter samples and with results obtained by other organizations for samples 


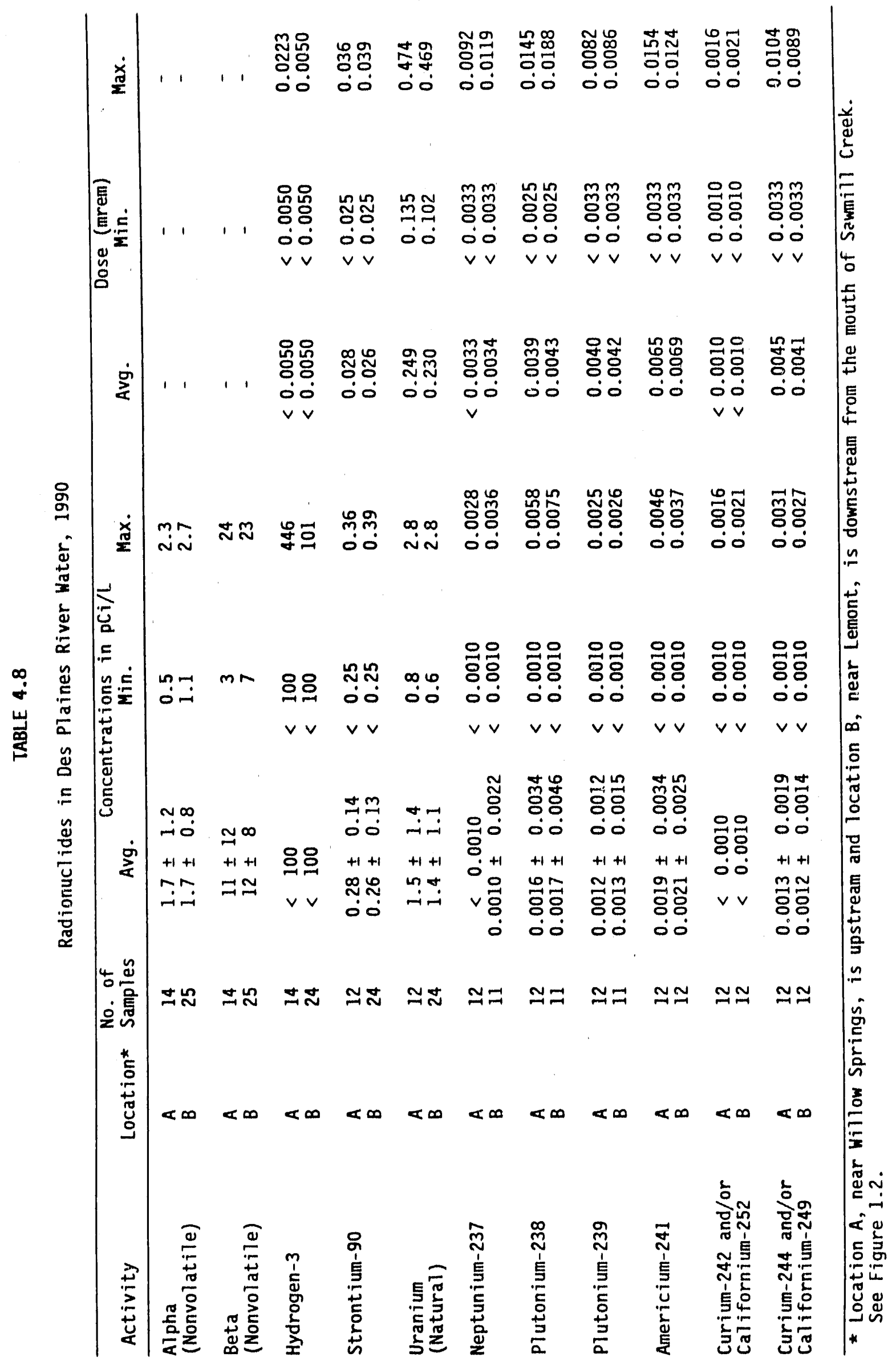




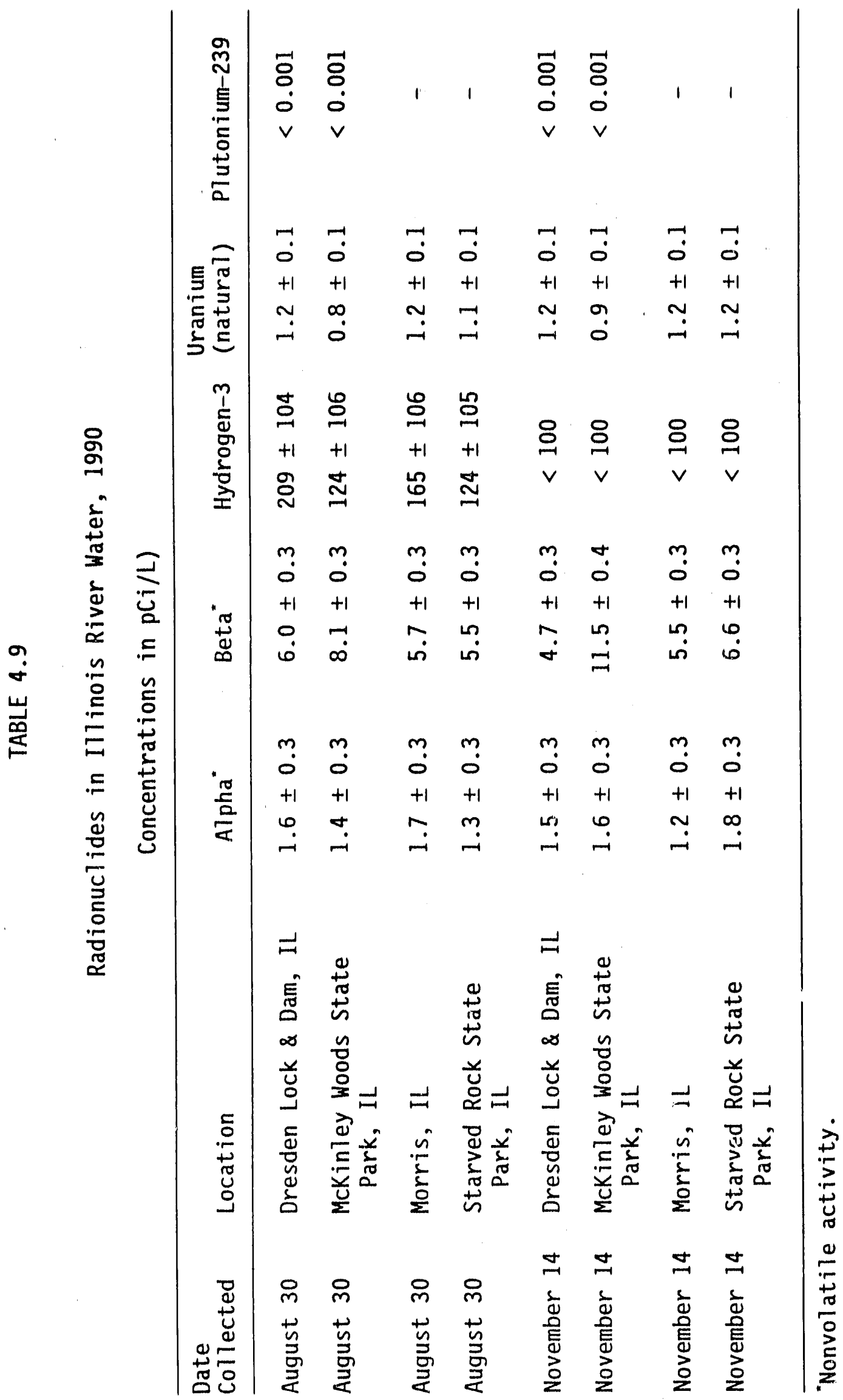


collected at large distances from nuclear installations. Such comparisons are useful in determining if the radioactivity of soil near ANL is normal. For this purpose, site-selection criteria and sample collection and sample preparation techniques recommended by the American Society for Testing and Materials (ASTM) were used." Sites were selected in several directions and at various distances from ANL. Each site was selected on the bas is that the soil appeared, or was known to have been, undisturbed for a number of years. Attempts were made to select open, levei, grassy areas that were mowed at reasonable intervals. Public parks were selected when available.

Each soil sample consisted of ten cores, totaling $864 \mathrm{~cm}^{2}\left(134 \mathrm{in}^{2}\right)$ in area by $5 \mathrm{~cm}$ ( $2 \mathrm{in}$ ) deep. Through 1976, samples had been collected down to $30 \mathrm{~cm}(12 \mathrm{in})$ to measure total deposition. The results of five years of sample collection at this depth has established the total deposition in the ANL environment. Reducing the sampling depth to $5 \mathrm{~cm}$ ( 2 in) will make the analysis more sensitive to changes in current deposition. The grass samples were obtained by collecting the grass from a $1 \mathrm{~m}^{2}\left(10 \mathrm{ft}^{2}\right)$ area in the immediate vicinity of a soil sample. A grab sample technique was used to obtain bottom sediments from water bodies. After drying, grinding, and mixing, $100 \mathrm{~g}$ portions of each soil, bottom sediment, and grass samples were analyzed by the same methods described in Section 4.2 for air-filter resi. dues. The plutonium and americium were separated from the same $100 \mathrm{~g}$ al $\mathrm{i}$ quot of soil. Results are given in terms of the oven-dried $\left(110^{\circ} \mathrm{C}\right)$ weight.

The results for the gamma-ray emitting nuclides in soil are presented in Table 4.10. Intermediate half-life fission products reported in 1986 have decayed to below their detection limits and no evidence of chernobyl fallout is apparent. The cesium-137 levels are similar to those found over the past several years and represent an accumulation from nuclear tests over a period of many years. The annual average concentrations for the perimeter and off-site samples were similar. The plutonium and americium concentrations are given in Table 4.11. The range and average concentrations of plutonium and americium in soil were similar at both perimeter and off-site sampling points. For fallout americium-241 in soil, about $10 \%$ is due to direct deposition, while about $90 \%$ is from the decay of the previously deposited plutonium-241. The americium-241/plutonium-239 ratio is consistent with the current estimated value for this ratio of $0.32 .{ }^{12}$ 


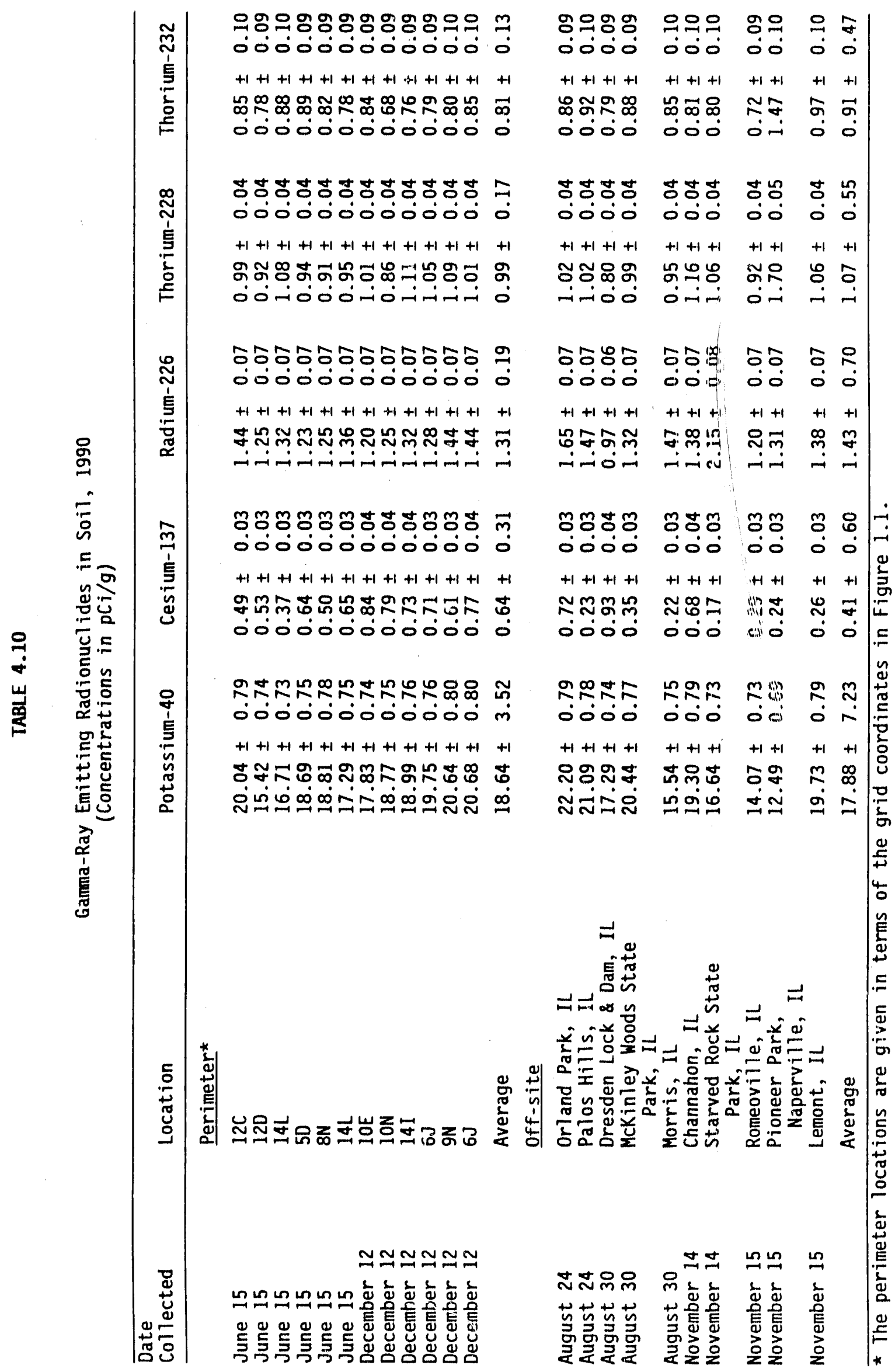




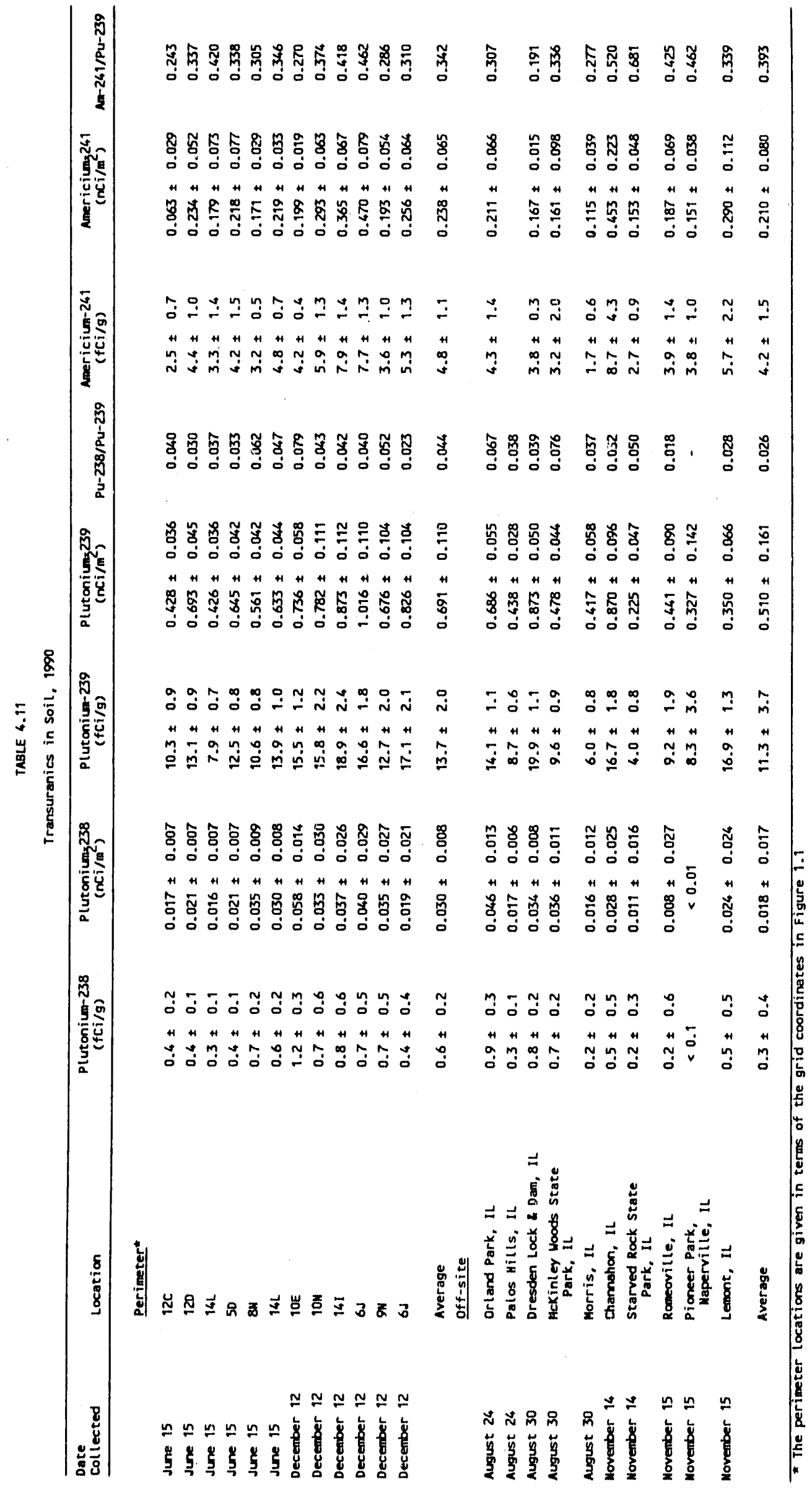


The radionuclide concentrations measured in grass are listed in Table 4.12. The annual averages and concentration ranges were similar at the perimeter and off-site locations and were similar to those of previous years, indicating no contribution from ANL operations. In terms of deposition, the plutonium-239 concentration was a factor of about $10^{4}$ less in the grass than in the soil from the same location.

Results of analyses of bottom sediment samples for gamma-ray emitters and transuranics are given in Table 4.13. The annual off-site averages were in the same range found in off-site samples collected in previous years. Plutonium results varied widely between locations and were strongly dependent on the retentiveness of the bottom material. A set of sediment samples was collected on September 28, 1990, from the Sawmill Creek bed, above, at the outfall, and at several locations below the point at which ANL discharges its treated waste water (location $7 M$ in Figure 1.1). The results, as listed in Table 4.13, show that the concentrations in the sample above the $7 M$ outfall are similar to those of the off-site samples. The plutonium, americium, and cesium-137 concentrations are slightly elevated below the outfal1, indicating that their origin is in ANL wastewater. In addition to the radionuclides listed in Table 4.13 , cobalt-60, up to $1 \mathrm{pCi} / \mathrm{g}$, was identified in the sediment below the outfall. The changes in concentrations of these nuclides with time and location indicate the dynamic nature of the sediment material in this area.

\subsection{Milk}

Fresh milk collected monthly through April from a local dairy farm south of Lemont was analyzed for several radionuclides. The farm was sold to a developer and the cows shipped to southern Illinois. No other dairy farm could be located near ANL and, therefore, the milk sampling and analysis program was terminated.

The water was separated from the milk by low-temperature vacuum evaporation, and the hydrogen-3 concentration was determined by liquid scintillation spectrometry. The strontium-90 was analyzed by the same method used for water and with the same detection limit. The results are 
TABLE 4.12

Radionuclides in Grass, 1990

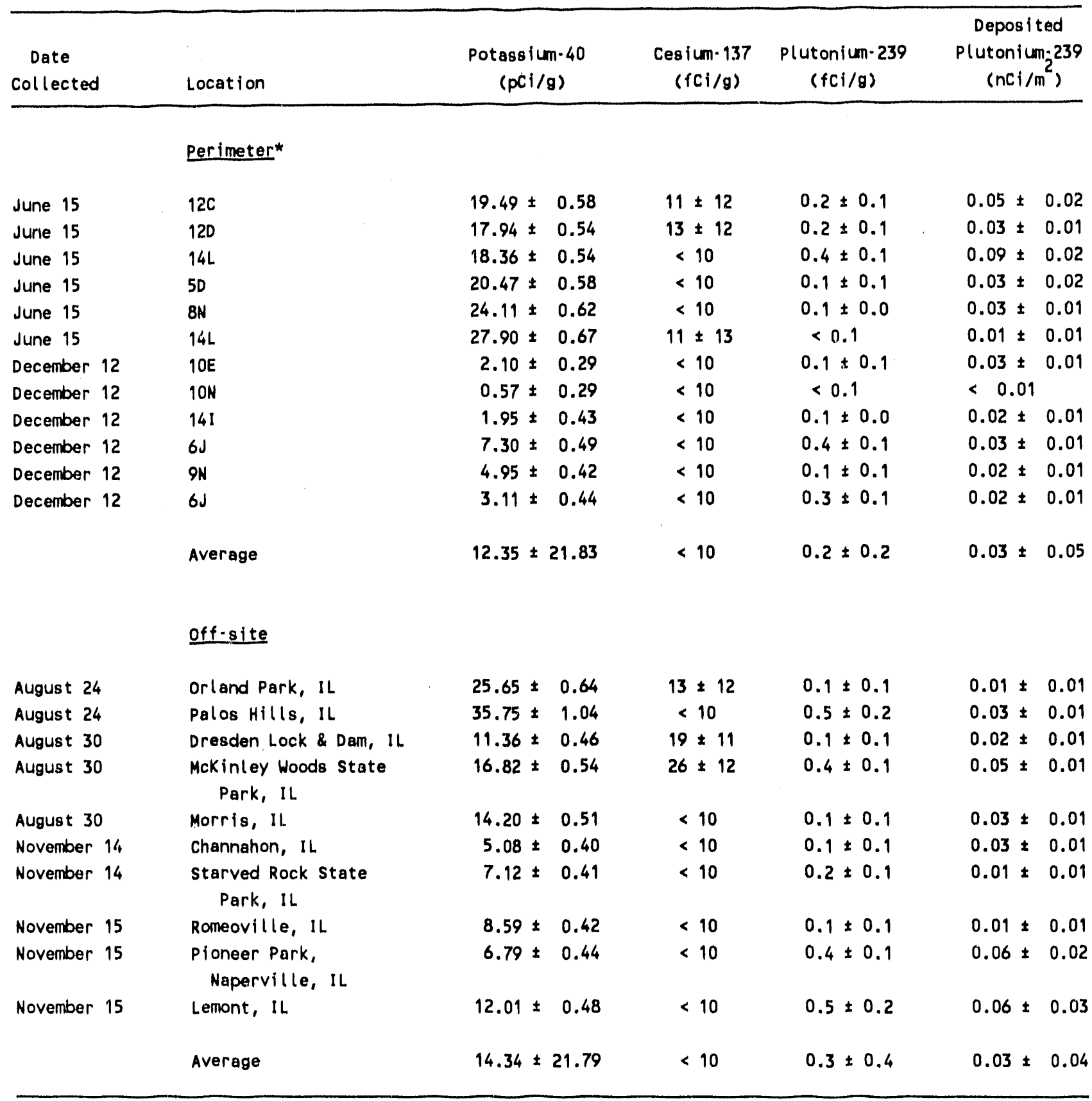

* The perimeter locations are given in terms of the grid coordinates in figure 1.1 


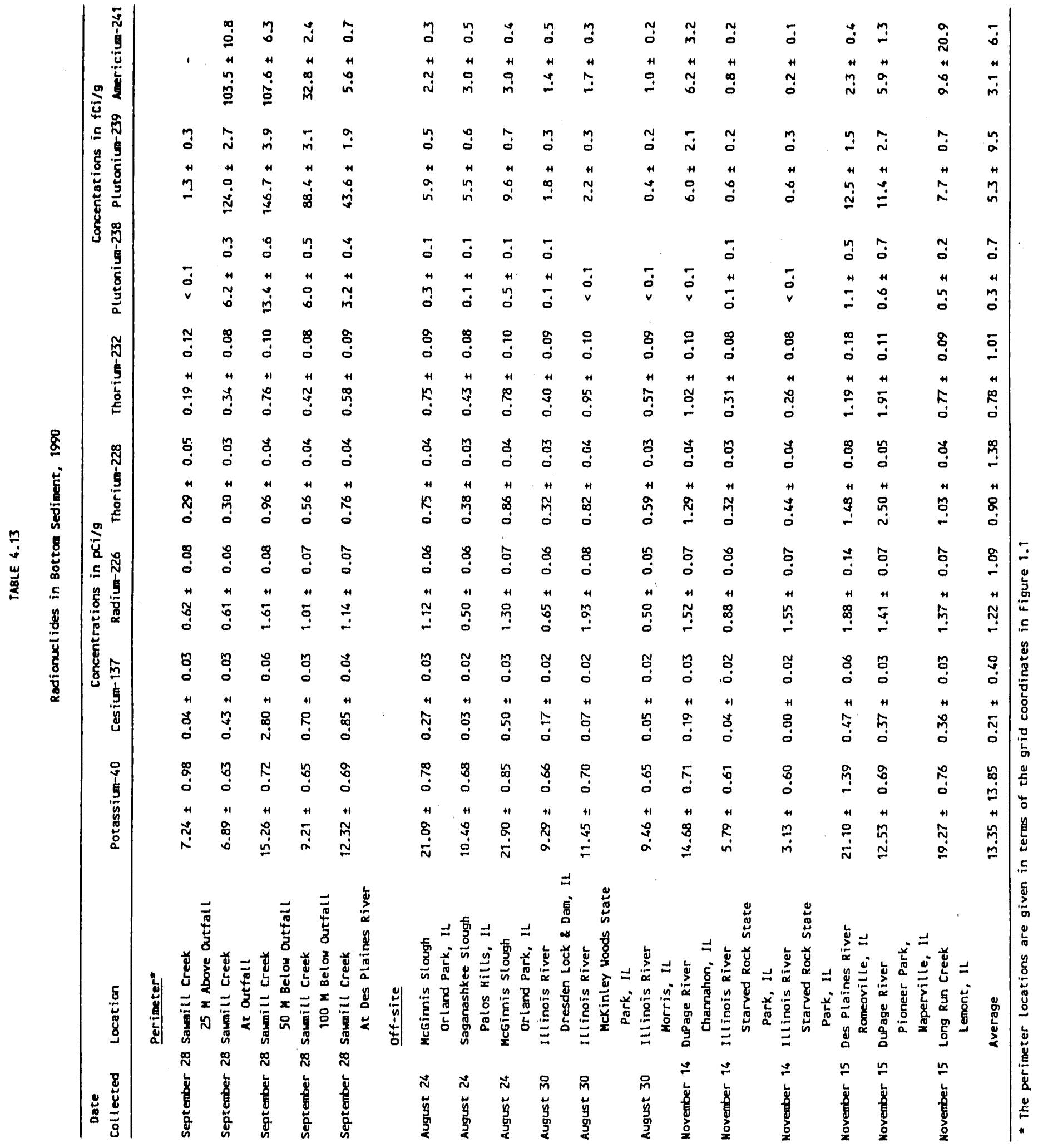


given in Table 4.14. All the hydrogen-3 concentrations were less than the detection 1 imit of $100 \mathrm{pCi} / \mathrm{L}$. The average strontium-90 concentration was similar to the 1989 concentration. These nuclides are products from nuclear tests and are not related to ANL operations.

TABLE 4.14

Strontium-90 in Milk, 1990

\begin{tabular}{ll}
\hline Date & $\mathrm{pCi} / \mathrm{L}$ \\
\hline Janlected & $2.2 \pm 0.1$ \\
February 3 & $1.3 \pm 1.3$ \\
March 7 & $1.7 \pm 0.1$ \\
Apri1 4 & $1.8 \pm 0.1$ \\
Average & $1.8 \pm 0.4$ \\
\hline
\end{tabular}

The concentrations given in Table 4.14 may be compared to the EPA drinking water 1 imits of $20 \mathrm{nCi} / \mathrm{L}$ for hydrogen-3 and $8 \mathrm{pCi} / \mathrm{L}$ for strontium90. The consumption of one 1 iter of milk per day would result in an average annual dose of $0.4 \mathrm{mrem} / \mathrm{y}$ for strontium-90 and $<0.25 \mathrm{mrem} / \mathrm{y}$ for hydrogen-3.

\subsection{External Penetrating Radiation}

Levels of external penetrating radiation at and in the vicinity of the ANL site were measured with calcium fluoride thermoluminescent dosimeter (TLD) chips. Each measurement reported represents the average of four chips exposed in the same packet. All calcium fluoride packets were shielded with $1.6 \mathrm{~mm}(1 / 16 \mathrm{in})$ copper foil to reduce or eliminate the beta and low-energy $X$-ray components. The response of the chips was determined with a $U$. S. National Institute of Standards and Technology (NIST) standard radium-226 source, and the results were calculated in terms of the air dose. Dosimeters were exposed at several locations at the site boundary and on the site. Readings were also taken at five off-site locations for comparison purposes. These locations are shown in Figure 1.2. 
The results are summarized in Tables 4.15 and 4.16, and the site boundary and on-site readings are also shown in Figure 4.4. Measurements were made for the four successive exposure periods shown in the tables, and the results were calculated in terms of annual dose for ease in comparing measurements made for different elapsed times. The uncertainty given in the tables for an average is the $95 \%$ confidence 1 imit calculated from the standard deviation of the average.

TABLE 4.15

Environmental Penetrating Radiation at Off-Site Locations, 1990

\begin{tabular}{lccccc}
\hline & \multicolumn{5}{c}{ Dose Rate (mrem/year) } \\
\cline { 2 - 6 } Location & $1 / 10-4 / 18$ & $4 / 18-7 / 17$ & $\begin{array}{c}\text { Period of Measurement } \\
7 / 17-10 / 23\end{array}$ & $10 / 23-1 / 15$ & Average \\
\hline Lemont & 87 & 84 & 83 & 88 & $86 \pm 2$ \\
Oak Brook & 89 & 89 & 86 & 86 & $88 \pm 2$ \\
Oak Lawn & 81 & 77 & 79 & 77 & $78 \pm 2$ \\
Orland Park & 79 & 82 & 82 & 78 & $80 \pm 1$ \\
Woodridge & 88 & 87 & 84 & 82 & $85 \pm 2$ \\
Average & $85 \pm 4$ & $84 \pm 4$ & $83 \pm 2$ & $82 \pm 4$ & $83 \pm 2$ \\
\hline
\end{tabular}

The off-site results averaged $83 \pm 2 \mathrm{mrem} / \mathrm{y}$ and were similar to last year's off-site average of $87 \pm 3 \mathrm{mrem} / \mathrm{y} .{ }^{13}$ If the off-site locations provided an accurate sample of the radiation background in the area, then annual averages at the site in the range of $83 \pm 2 \mathrm{mrem} / \mathrm{y}$ may be considered normal with a $95 \%$ probability. To compare boundary results for individual sampling periods, the standard deviation of the 20 individual off-site results is useful. This value is $2 \mathrm{mrem} / \mathrm{y}$, so individual results in the range of $83 \pm 4 \mathrm{mrem} / \mathrm{y}$ may be considered to be the average natural background with a $95 \%$ probability.

At two site boundary locations, $7 I$ (south) and $14 I$ (north), the dose rates were consistently above the average background. At 7 I this was due to radiation from ANL's Radioactive Waste Storage Facility (317 Area) in the 
TABLE 4.16

Environmental Penetrating Radiation at ANL, 1990

\begin{tabular}{|c|c|c|c|c|c|}
\hline \multirow[b]{2}{*}{ Location" } & \multicolumn{5}{|c|}{ Dose Rate (mrem/year) } \\
\hline & $1 / 10-4 / 18$ & $\begin{array}{l}\text { Period of } \\
4 / 18-7 / 17\end{array}$ & $\begin{array}{r}\text { Measurement } \\
7 / 17-10 / 23\end{array}$ & $10 / 23-1 / 15$ & Average \\
\hline 14L - Boundary & 78 & 75 & 75 & 74 & $76 \pm 2$ \\
\hline 14I - Boundary & 103 & 94 & 95 & 91 & $96 \pm 4$ \\
\hline $14 G$ - Boundary & 86 & 90 & 88 & - & $88 \pm 2$ \\
\hline 9/10EF - Boundary & 80 & 85 & 83 & 78 & $81 \pm 3$ \\
\hline $8 \mathrm{H}-$ Boundary & 81 & 85 & 83 & 80 & $82 \pm 2$ \\
\hline $\begin{array}{l}8 \mathrm{H} \text { - Boundary, Center, } \\
\text { St. Patrick's } \\
\text { Cemetery }\end{array}$ & 89 & 84 & 81 & 82 & $84 \pm 3$ \\
\hline $7 I$ - Boundary & 211 & 206 & 144 & 99 & $165 \pm 45$ \\
\hline $\begin{array}{l}6 I-200 \mathrm{~m} \mathrm{~N} \text { of } \\
\text { Quarry Road }\end{array}$ & 85 & 90 & 88 & 84 & $87 \pm 2$ \\
\hline $9 H-50 \mathrm{~m}$ SE of $\mathrm{CP}-5$ & 1080 & 1040 & 970 & 971 & $1015 \pm 46$ \\
\hline $\begin{array}{l}8 \mathrm{H}-65 \mathrm{~m} \mathrm{~S} \text { of } \\
\text { Building } 316\end{array}$ & 78 & 78 & 77 & 77 & $78 \pm 1$ \\
\hline $\begin{array}{l}8 H-200 \mathrm{~m} \text { NW of } \\
\text { Waste Storage } \\
\text { Area (Heliport) }\end{array}$ & 85 & 89 & 90 & 82 & $86 \pm 3$ \\
\hline $\begin{array}{c}7 \text { - Center, Waste } \\
\text { Storage Area } \\
\text { Facility } 317\end{array}$ & 5870 & 5690 & 4270 & 1490 & $4330 \pm 1718$ \\
\hline $\begin{array}{r}10 / 11 \mathrm{~K} \text { - Lodging } \\
\text { Facilities }\end{array}$ & 72 & 74 & 71 & 71 & $72 \pm 1$ \\
\hline $\begin{array}{l}9 \mathrm{I}-65 \mathrm{~m} \mathrm{NE} \text { of } \\
\text { Building } 350, \\
230 \mathrm{~m} \mathrm{NE} \text { of } \\
\text { Building } 316\end{array}$ & 76 & 71 & 70 & 73 & $72 \pm 2$ \\
\hline
\end{tabular}

"See Figure 1.1. 


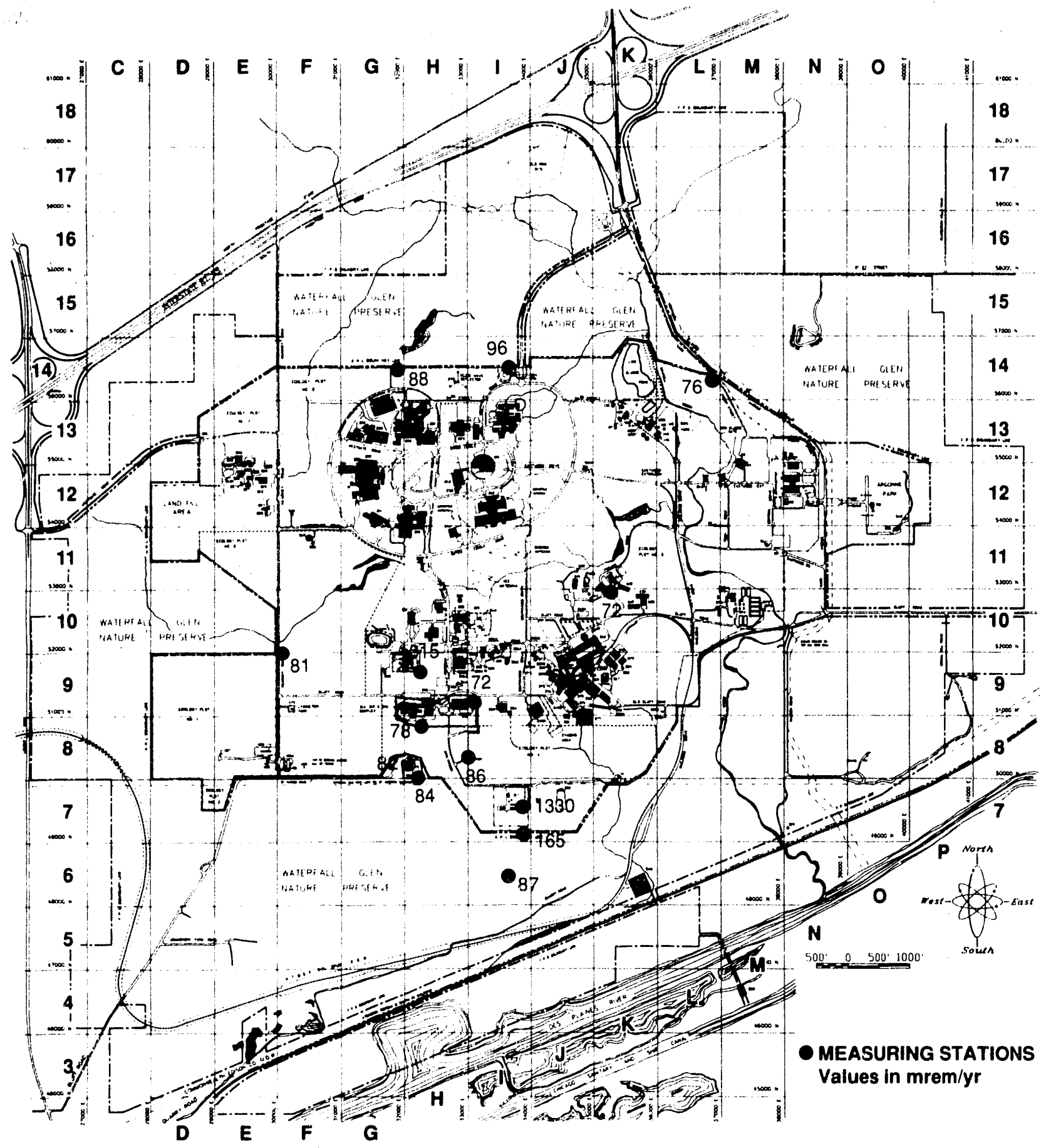

Figure 4.4 Penetrating Radiation Measurements at the ANL Site, 1990 
northern half of grid 7I. Waste is packaged and temporarily kept in this area before removal for permanent disposal off-site. The net above-background dose at this perimeter fence location was about $82 \mathrm{mrem} / \mathrm{y}$. In previous years, this value has ranged from $865 \mathrm{mrem} / \mathrm{y}$ in 1985 to $51 \mathrm{mrem} / \mathrm{y}$ in 1988. About $300 \mathrm{~m}(0.2 \mathrm{mi})$ south of the fence in grid $6 \mathrm{I}$, the measured dose dropped to $87 \pm 2 \mathrm{mrem} / \mathrm{y}$, within the normal background range.

Examination of Table 4.16 indicates a significant reduction in dose at the center of the waste storage area (7I) and at the 7I south boundary. This is primarily due to the shipment of TRU waste, stored in the 317 Area subsurface vaults, to INEL. These shipments occurred during September and October 1990. ANL was unable to ship waste to INEL from mid-1988 to this time due to a directive from the Governor of Idaho prohibiting shipment of radioactive waste into the state. Although low-level radioactive waste still remains within the 317 Area, the dose from this raterial is significantly less than the material removed to INEL. The 317 Area south fenceline dose, i.e., $99 \mathrm{mrem} / \mathrm{y}$ for the fourth quarter, is approaching the normal background level.

The other elevated perimeter area was at Location 14I, at the north boundary, where a dose of $13 \mathrm{mrem} / \mathrm{y}$ above background was measured. This is about one-half of the value of $23 \mathrm{mrem} / \mathrm{y}$ measured in 1989 . This dose is attributed to the use of cobalt-60 irradiation sources in Building 202. An elevated on-site dose was measured at Location $9 \mathrm{H}$, next to the $\mathrm{CP}-5$ facility, where irradiated hardware from $C P-5$ is stored.

\subsection{Estimates of Potential Radiation Doses}

The radiation doses at the site boundary and off the site that could have been received by the public from radioactive materials and radiation leaving the site were calculated. These calculations were made for three exposure pathways, airborne, water, and direct radiation from external sources. 


\subsubsection{Airborne Pathway}

Guidance issued by the $D O E^{6}$ stipulates that DOE facilities with airborne releases of radioactive materials are subject to 40 CFR Part 61 , Subpart $H,{ }^{14}$ which requires the use of the CAP- 88 version of the EPA-AIRDOSE/RADRISK code to calculate the dose for radionuclides released to the air and to demonstrate compliance with the regulation. The dose limit applicable for CY 1990 for the air pathway is $10 \mathrm{mrem} / \mathrm{y}$ effective dose equivalent. The EPA-AIRDOSE/RADRISK computer code uses a modified Gaussian plume equation to estimate both horizontal and vertical dispersion of radionuclides released to the air from stacks or area sources. For 1990, doses were calculated for h:drogen-3, carbon-11, nitrogen-13, oxygen-15, argon-41, krypton-85, radon220 plus daughters and a number of actinide radionuclides. The annual release rates are those 1 isted in Table 4.4, and separate calculations were performed for each of the seven release points. The wind speed and direction data shown in Figure 1.3 were used for these calculations. Doses were calculated for an area extending out to $80 \mathrm{~km}(50 \mathrm{mi})$ from ANL. The upgraded population distribution of the 16 compass segments and ten distance increments given in Table 1.1 was used. The dose rate was calculated at the midpoint of each interval and integrated over the entire area to give the annual population cumulative dose.

Distances from the specific facilities that exhaust radiological airborne emissions (see Table 4.4) to the fenceline (perimeter) and nearest resident were determined in the 16 compass segments. The EPA-AIRDOSE/RADRISK computer code was used to calculate the dose at each of these locations. Calculations also were performed to evaluate the major airborne pathways; ingestion, inhalation, and immersion, both at the point of maximum perimeter exposure and to the maximally exposed resident. The perimeter and resident doses and the maximum doses are listed, respectively, for releases from Buildings 200 and 211 (Tables 4.17 and 4.18), Building 202 (Tables 4.19 and 4.20), Building 205 (Tables 4.21 and 4.22), Building 212 (Tables 4.23 and 4.24), Building 330 (Tables 4.25 and 4.26), Building 350 (Tables 4.27 and 4.28), and Building 375 (Tables 4.29 and 4.30). The doses given in these tables are the committed whole body effective dose equivalents. 
TABLE 4.17

Radiological Airborne Releases from Buildings 200 and 211, 1990

Source Term: Carbon-11 $=0.60 \mathrm{Ci}$

Nitrogen $-13=0.96 \mathrm{Ci}$

Oxygen $-15=5.79 \mathrm{Ci}$

Fluorine-18 $=0.02 \mathrm{Ci}$

Argon-41 $=0.04 \mathrm{Ci}$

Radon-220 $=2606 \mathrm{Ci}$ (plus daughters)

Radon-222 $=0.09 \mathrm{Ci}$ (plus daughters)

\begin{tabular}{lcccc}
\hline Direction & $\begin{array}{c}\text { Distance to } \\
\text { Perimeter }(\mathrm{m})\end{array}$ & $\begin{array}{c}\text { Dose } \\
(\mathrm{mrem} / \mathrm{y})\end{array}$ & $\begin{array}{c}\text { Distance to } \\
\text { Nearest Resident }\end{array}$ & $\begin{array}{c}\text { Dose } \\
(\mathrm{mrem} / \mathrm{y})\end{array}$ \\
\hline N & 500 & 1.23 & 1000 & 0.34 \\
NNE & 600 & 0.94 & 1100 & 0.31 \\
NE & 750 & 0.49 & 2600 & 0.06 \\
ENE & 1700 & 0.09 & 3100 & 0.03 \\
E & 2400 & 0.06 & 3500 & 0.03 \\
ESE & 2200 & 0.05 & 3600 & 0.02 \\
SE & 2100 & 0.04 & 4000 & 0.02 \\
SSE & 2000 & 0.05 & 4000 & 0.02 \\
S & 1500 & 0.04 & 4000 & 0.01 \\
SSW & 1000 & 0.21 & 2500 & 0.05 \\
SW & 800 & 0.56 & 2200 & 0.12 \\
WSW & 1100 & 0.12 & 1500 & 0.07 \\
W & 750 & 0.22 & 1500 & 0.07 \\
WNW & 800 & 0.17 & 1300 & 0.08 \\
NW & 600 & 0.38 & 1100 & 0.14 \\
NNW & 600 & 0.56 & 800 & 0.34 \\
& & & & \\
\hline
\end{tabular}


TABLE 4.18

Maximum Perimeter and Individual Doses from

Buildings 200 and 211 Air Emissions, 1990

Dose $(\mathrm{mrem} / \mathrm{y})$

\begin{tabular}{lcc}
\hline Pathway & Perimeter $(500 \mathrm{~m} \mathrm{~N})$ & Individual $(1000 \mathrm{~m} \mathrm{~N})$ \\
\hline Ingestion & 0.0001 & $<0.0001$ \\
Inhalation & 1.22 & 0.34 \\
Air Immersion & 0.012 & 0.0031 \\
Ground Surface & 0.0006 & 0.002 \\
Total & 1.23 & 0.34 \\
Radionuclide & & \\
Carbon-11 & & \\
Nitrogen-13 & 0.0004 & 0.0001 \\
Oxygen-15 & 0.0006 & 0.0002 \\
Fluorine-18 & 0.0026 & 0.0005 \\
Argon-41 & 0.0001 & $<0.0001$ \\
Polonium-210 & 0.0001 & $<0.0001$ \\
Bismuth-210 & 0.0004 & 0.0002 \\
Lead-210 & 0.0001 & $<0.0001$ \\
Tha11ium-208 & 0.0001 & 0.0001 \\
Bismuth-212 & 0.0075 & 0.0019 \\
Lead-212 & 0.140 & 0.048 \\
Polonium-216 & 0.702 & 0.243 \\
Radon-220 & 0.0001 & 0.0001 \\
Radon-222 & 0.375 & 0.047 \\
Total & 0.0003 & 0.0001 \\
\hline & 1.23 & 0.34 \\
\hline & &
\end{tabular}


TABLE 4.19

Radiological Airborne Releases from Building 202 (JANUS), 1990 Source Term: Argon-41 $=1.23 \mathrm{Ci}$

\begin{tabular}{lcccc}
\hline Direction & $\begin{array}{c}\text { Distance to } \\
\text { Perimeter }\end{array}(\mathrm{m})$ & $\begin{array}{c}\text { Dose } \\
(\mathrm{mrem} / \mathrm{y})\end{array}$ & $\begin{array}{c}\text { Distance to } \\
\text { Nearest Resident }\end{array}$ & $\begin{array}{c}\text { Dose } \\
(\mathrm{mrem} / \mathrm{y})\end{array}$ \\
\hline N & 200 & 0.0002 & 1700 & 0.0001 \\
NNE & 250 & 0.0002 & 1800 & 0.0001 \\
NE & 350 & 0.0003 & 1500 & 0.0001 \\
ENE & 800 & 0.0002 & 2200 & $<0.0001$ \\
E & 1100 & 0.0001 & 2200 & $<0.0001$ \\
ESE & 1600 & $<0.0001$ & 2700 & $<0.0001$ \\
SE & 1600 & $<0.0001$ & 4000 & $<0.0001$ \\
SSE & 1700 & $<0.0001$ & 4000 & $<0.0001$ \\
S & 2100 & $<0.0001$ & 4000 & $<0.0001$ \\
SSW & 2200 & $<0.0001$ & 4000 & $<0.0001$ \\
SW & 2600 & $<0.0001$ & 3200 & $<0.0001$ \\
WSW & 2000 & $<0.0001$ & 2600 & $<0.0001$ \\
W & 1500 & $<0.0001$ & 2100 & $<0.0001$ \\
WNW & 1000 & $<0.0001$ & 1300 & $<0.0001$ \\
NW & 300 & 0.0001 & 1000 & 0.0001 \\
NNW & 250 & 0.0002 & 800 & 0.0002 \\
& & & & \\
\hline
\end{tabular}


TABLE 4.20

Maximum Perimeter and Individual Doses from

Building 202 (JANUS) Air Emissions, 1990

Dose (mrem/y)

\begin{tabular}{lcc}
\hline Pathway & Perimeter $(350 \mathrm{~m} \mathrm{NE})$ & Individual $(800 \mathrm{~m} \mathrm{NNW})$ \\
\hline Ingestion & $<0.0001$ & $<0.0001$ \\
Inhalation & $<0.0001$ & $<0.0001$ \\
Air Immersion & 0.0003 & 0.0003 \\
Ground Surface & 0.0001 & $<0.0001$ \\
Total & 0.0003 & 0.0002 \\
Radionuclide & & \\
Argon-41 & 0.0003 & 0.0002 \\
\hline
\end{tabular}


TABLE 4.21

Radiological Airborne Releases from Building 205, 1990

Source Term: Hydrogen-3 $=0.16 \mathrm{Ci}$

\begin{tabular}{lcccc}
\hline Direction & $\begin{array}{c}\text { Distance to } \\
\text { Perimeter }(\mathrm{m})\end{array}$ & $\begin{array}{c}\text { Dose } \\
(\mathrm{mrem} / \mathrm{y})\end{array}$ & $\begin{array}{c}\text { Distance to } \\
\text { Nearest Resident }\end{array}$ & $\begin{array}{c}\text { Dose } \\
(\mathrm{mrem} / \mathrm{y})\end{array}$ \\
\hline N & 850 & $<0.0001$ & 1300 & $<0.0001$ \\
NNE & 1000 & $<0.0001$ & 2100 & $<0.0001$ \\
NE & 1200 & $<0.0001$ & 2700 & $<0.0001$ \\
ENE & 2400 & $<0.0001$ & 3000 & $<0.0001$ \\
E & 2200 & $<0.0001$ & 3400 & $<0.0001$ \\
ESE & 2000 & $<0.0001$ & 3500 & $<0.0001$ \\
SE & 1800 & $<0.0001$ & 3900 & $<0.0001$ \\
SSE & 1500 & $<0.0001$ & 4000 & $<0.0001$ \\
S & 1300 & $<0.0001$ & 3900 & $<0.0001$ \\
SSW & 1100 & $<0.0001$ & 2400 & $<0.0001$ \\
SW & 900 & $<0.0001$ & 2100 & $<0.0001$ \\
WSW & 1100 & $<0.0001$ & 1800 & $<0.0001$ \\
W & 1300 & $<0.0001$ & 1800 & $<0.0001$ \\
WNW & 1100 & $<0.0001$ & 1700 & $<0.0001$ \\
NW & 1100 & $<0.0001$ & 1500 & $<0.0001$ \\
NNW & 900 & $<0.0001$ & 1500 & $<0.0001$ \\
& & & & \\
\hline
\end{tabular}




\section{TABLE 4.22}

Maximum Perimeter and Individual Doses from

Butlding 205 Air Emissions, 1990

$$
\text { Dose (mrem/y) }
$$

\begin{tabular}{lcc}
\hline Pathway & Perimeter $(850 \mathrm{~m} \mathrm{~N})$ & Individual $(1300 \mathrm{~m} \mathrm{~N})$ \\
\hline Ingestion & $<0.0001$ & $<0.0001$ \\
Inhalation & $<0.0001$ & $<0.0001$ \\
Air Immersion & $<0.0001$ & $<0.0001$ \\
Ground Surface & $<0.0001$ & $<0.0001$ \\
Total & $<0.0001$ & $<0.0001$ \\
Radionuclide & & \\
Hydrogen-3 & $<0.0001$ & $<0.0001$ \\
\hline
\end{tabular}


TABLE 4.23

Radiological Airborne Releases from Butlding 212, 1990

Source Term: Hydrogen $-3(H T)=5.25 \mathrm{CI}$

Hydrogen $-3($ HTO $)=2.85 \mathrm{Ct}$

Krypton $-85=5.18 \mathrm{CH}$

Ant imony $-125=1.4 \times 10^{-4} \mathrm{Ct}$

Radon-220 $=0.05 \mathrm{Ct}$

\begin{tabular}{lcccc}
\hline Direction & $\begin{array}{c}\text { Distance to } \\
\text { Perimeter }\end{array}(\mathrm{m})$ & $\begin{array}{c}\text { Dose } \\
\text { (mrem/y) }\end{array}$ & $\begin{array}{c}\text { Distance to } \\
\text { Nearest Restdent }\end{array}$ & $\begin{array}{c}\text { Dose } \\
(\mathrm{mrem} / \mathrm{y})\end{array}$ \\
\hline N & 800 & 0.0008 & 2000 & 0.0002 \\
NNE & 1000 & 0.0006 & 2500 & 0.0002 \\
NE & 1300 & 0.0003 & 2000 & 0.0002 \\
ENE & 1500 & 0.0002 & 2500 & $<0.0001$ \\
E & 1600 & 0.0002 & 2800 & $<0.0001$ \\
ESE & 1200 & 0.0002 & 2500 & $<0.0001$ \\
SE & 1400 & 0.0002 & 3500 & $<0.0001$ \\
SSE & 1400 & 0.0002 & 4500 & $<0.0001$ \\
S & 1500 & $<0.0001$ & 5000 & $<0.0001$ \\
SSW & 1600 & 0.0002 & 5000 & $<0.0001$ \\
SW & 1400 & 0.0004 & 2400 & 0.0002 \\
WSW & 1300 & 0.0002 & 2300 & $<0.0001$ \\
W & 1700 & 0.0001 & 2200 & $<0.0001$ \\
WNW & 1500 & 0.0001 & 2000 & $<0.0001$ \\
NW & 1300 & 0.0002 & 2000 & 0.0001 \\
NNW & 1000 & 0.0004 & 2000 & 0.0001 \\
\hline
\end{tabular}




\section{TABLE 4.24}

Maximum Perimeter and Individual Doses from Butlding 212 Atr Emisstons, 1990

Dose $(\mathrm{mrem} / \mathrm{y})$

\begin{tabular}{lcc}
\hline Pathway & Perimeter $(800 \mathrm{~m} \mathrm{~N})$ & Individual $(2400 \mathrm{~m} \mathrm{SW})$ \\
\hline Ingestion & 0.0002 & $<0.0001$ \\
Inhalation & 0.0006 & 0.0002 \\
Air Imnersion & 0.0001 & $<0.0001$ \\
Ground Surface & $<0.0001$ & $<0.0001$ \\
Total & 0.0008 & 0.0002 \\
Radionuclide & & \\
Hydrogen-3 & & \\
Kryption-85 & 0.0007 & 0.0002 \\
Antimony-125 & 0.0001 & $<0001$ \\
Radon-220 & 0.0001 & 0.0001 \\
Total & 0.0001 & 0.0001 \\
\hline
\end{tabular}


TABLE 4.25

Radiological Atrborne Releases from Butlding 330 (CP-5), 1990 Source Term: Hydrogen-3 (HTO) $=11.7 \mathrm{Cl}$

\begin{tabular}{lcccc}
\hline Direction & $\begin{array}{c}\text { Distance to } \\
\text { Perimeter }(\mathrm{m})\end{array}$ & $\begin{array}{c}\text { Dose } \\
(\mathrm{mrem} / \mathrm{y})\end{array}$ & $\begin{array}{c}\text { Distance to } \\
\text { Nearest Resident }\end{array}$ & $\begin{array}{c}\text { Dose } \\
(\mathrm{mrem} / \mathrm{y})\end{array}$ \\
\hline N & 1500 & 0.0001 & 2000 & 0.0003 \\
NNE & 1800 & 0.0003 & 3300 & 0.0001 \\
NE & 2100 & 0.0002 & 2800 & 0.0001 \\
ENE & 2200 & 0.0002 & 3300 & $<0.0001$ \\
E & 1500 & 0.0003 & 3100 & $<0.0001$ \\
ESE & 1300 & 0.0003 & 3500 & $<0.0001$ \\
SE & 1200 & 0.0002 & 3500 & $<0.0001$ \\
SSE & 1000 & 0.0003 & 3500 & $<0.0001$ \\
S & 500 & 0.0005 & 3000 & $<0.0001$ \\
SSW & 700 & 0.0008 & 3500 & $<0.0001$ \\
SW & 900 & 0.0010 & 2400 & 0.0003 \\
WSW & 1400 & 0.0005 & 2000 & 0.0001 \\
W & 700 & 0.0002 & 2000 & 0.0001 \\
WNW & 700 & 0.0004 & 1900 & 0.0001 \\
NW & 1500 & 0.0002 & 2000 & 0.0001 \\
NNW & 1600 & 0.0003 & 1900 & 0.0002 \\
& & & & \\
\hline
\end{tabular}


TABLE 4.26

Maximum Perimeter and Individual Doses from

Building 330 (CP-5) Air Emissions, 1990

Dose $(\mathrm{mrem} / \mathrm{y})$

\begin{tabular}{lcc}
\hline Pathway & Perimeter $(900 \mathrm{~m} \mathrm{SW})$ & Individual $(2000 \mathrm{~m} \mathrm{~N})$ \\
\hline Ingestion & 0.0002 & $<0.0001$ \\
Inhalation & 0.0008 & 0.0002 \\
Air Immersion & $<0.0001$ & $<0.0001$ \\
Ground Surface & $<0.0001$ & $<0.0001$ \\
Total & 0.0010 & 0.0003 \\
Radionuclide & & \\
Hydrogen-3 & & 0.0003 \\
\hline
\end{tabular}


TABLE 4.27

Radiological Airborne Releases from Butlding 350, 1990

Source Term: Urantum-234 $=4.2 \times 10^{-6} \mathrm{Ci}$ Uranium-238 $=4.2 \times 10^{-6} \mathrm{Ci}$

Plutonium-238 $=3.1 \times 10^{-5} \mathrm{Cl}$

Plutonfum-239 $=3.4 \times 10^{-5} \mathrm{Ci}$

Pluton fum-240 $=8.1 \times 10^{-6} \mathrm{Ct}$

Plutonfum-241 $=1.9 \times 10^{-3} \mathrm{C}$

P1utonium-242 $=1.6 \times 10^{-8} \mathrm{Ci}$

Neptunium-237 $=1.4 \times 10^{-8} \mathrm{Ci}$

Americium-241 $=3.1 \times 10^{-5} \mathrm{CI}$

Americium-243 $=2.0 \times 10^{-7} \mathrm{Ci}$

\begin{tabular}{lcccc}
\hline Direction & $\begin{array}{c}\text { Distance to } \\
\text { Perimeter }\end{array}$ & $\begin{array}{c}\text { Dose } \\
(\mathrm{m})\end{array}$ & $\begin{array}{c}\text { Distance to } \\
\text { (mem/y) }\end{array}$ & $\begin{array}{c}\text { Dose } \\
\text { Nearest Resident }\end{array}$ \\
\hline N & 1700 & 0.0066 & 2200 & 0.0048 \\
NNE & 1800 & 0.0061 & 3200 & 0.0031 \\
NE & 2200 & 0.0039 & 3100 & 0.0025 \\
ENE & 2000 & 0.0033 & 3100 & 0.0019 \\
E & 1700 & 0.0039 & 2500 & 0.0025 \\
ESE & 900 & 0.0062 & 3000 & 0.0017 \\
SE & 900 & 0.0053 & 3000 & 0.0014 \\
SSE & 700 & 0.0066 & 2700 & 0.0017 \\
S & 600 & 0.0026 & 2700 & 0.0008 \\
SSW & 400 & 0.0050 & 2500 & 0.0025 \\
SW & 600 & 0.0093 & 2700 & 0.0040 \\
WSW & 800 & 0.0043 & 2100 & 0.0020 \\
W & 900 & 0.0039 & 2200 & 0.0018 \\
WNW & 1000 & 0.0028 & 2100 & 0.0015 \\
NW & 1900 & 0.0024 & 2400 & 0.0019 \\
NNW & 1900 & 0.0037 & 2200 & 0.0031 \\
\hline
\end{tabular}


TABLE 4.28

Maximum Perimeter and Individual Doses from

Building 350 Air Emissions, 1990

Dose $(\mathrm{mrem} / \mathrm{y})$

\begin{tabular}{lcc}
\hline Pathway & Perimeter $(600 \mathrm{~m} \mathrm{SW})$ & Individual $(2200 \mathrm{~m} \mathrm{~N})$ \\
\hline Ingestion & 0.0001 & $<0.0001$ \\
Inhalation & 0.0092 & 0.0048 \\
Air Immersion & 0.0001 & $<0.0001$ \\
Ground Surface & 0.0001 & $<0.0001$ \\
Total & 0.0093 & 0.0048 \\
Radionuclide & & \\
Uranium-234 & & \\
Uranium-238 & $<0.0001$ & $<0.0001$ \\
Plutonium-238 & $<0.0001$ & $<0.0001$ \\
Plutonium-240 & 0.0017 & 0.0009 \\
Plutonium-241 & $<0.0001$ & $<0.0001$ \\
Plutonium-242 & 0.0021 & 0.0011 \\
Neptunium-237 & $<0.0001$ & $<0.0001$ \\
Americium-241 & $<0.0001$ & $<0.0001$ \\
Americium-243 & 0.0032 & 0.0016 \\
Total & $<0.0001$ & $<0.0001$ \\
\hline
\end{tabular}


TABLE 4.29

Radiological Airborne Releases from Building 375 (IPNS), 1990

Source Term: Carbon-11 $=86.1 \mathrm{Ci}$

Argon $-41=3.5 \mathrm{Ci}$

\begin{tabular}{lcccc}
\hline Direction & $\begin{array}{c}\text { Distance to } \\
\text { Perimeter }\end{array}(\mathrm{m})$ & $\begin{array}{c}\text { Dose } \\
(\mathrm{mrem} / \mathrm{y})\end{array}$ & $\begin{array}{c}\text { Distance to } \\
\text { Nearest Resident }\end{array}$ & $\begin{array}{c}\text { Dose } \\
(\mathrm{mrem} / \mathrm{y})\end{array}$ \\
\hline N & 1600 & 0.0100 & 3200 & 0.0030 \\
NNE & 1700 & 0.0097 & 3100 & 0.0034 \\
NE & 1700 & 0.0078 & 2700 & 0.0035 \\
ENE & 1500 & 0.0072 & 2500 & 0.0030 \\
E & 600 & 0.030 & 2500 & 0.0035 \\
ESE & 600 & 0.026 & 2500 & 0.0025 \\
SE & 600 & 0.022 & 2500 & 0.0021 \\
SSE & 600 & 0.022 & 3000 & 0.0016 \\
S & 800 & 0.0069 & 3000 & 0.0007 \\
SSW & 800 & 0.019 & 3500 & 0.0015 \\
SW & 800 & 0.032 & 4000 & 0.0018 \\
WSW & 1500 & 0.0047 & 2700 & 0.0017 \\
W & 2200 & 0.0024 & 2700 & 0.0015 \\
WNW & 1500 & 0.0040 & 2600 & 0.0016 \\
NW & 2200 & 0.0030 & 2500 & 0.0024 \\
NNW & 1800 & 0.0056 & 2200 & 0.0040 \\
& & & & \\
\hline
\end{tabular}


TABLE 4.30

Maximum Perimeter and Individual Doses from Building 375 Air Emissions, 1930

Dose $(\mathrm{mrem} / \mathrm{y})$

\begin{tabular}{lcc}
\hline Pathway & Perimeter $(800 \mathrm{~m} \mathrm{SW})$ & Individual $(2200 \mathrm{~m} \mathrm{NNW})$ \\
\hline Ingestion & 0.0001 & $<0.0001$ \\
Inhalation & 0.0014 & 0.0002 \\
Air Immersion & 0.0297 & 0.0037 \\
Ground Surface & 0.0011 & 0.0002 \\
Total & 0.0322 & 0.0040 \\
Radionuclide & & \\
Carbon-11 & & \\
Argon-41 & 0.0304 & 0.0038 \\
Total & 0.0018 & 0.0002 \\
\hline
\end{tabular}


The dominant contributor to the calculated doses was the radon-220 and daughters released from Building 200 . This accounted for $98 \%$ of the offsite dose in 1990. The highest perimeter dose rates were in the north sector with a maximum dose of $1.2 \mathrm{mrem} / \mathrm{y}$ at a fenceline location north of Building 203 (location $14 \mathrm{H}$ in Figure 1.1). The major contributor to this dose was inhalation of lead-212 $(0.70 \mathrm{mrem} / \mathrm{y})$ and the organs receiving the greatest dose were the lung and the bone. The releases from the other facilities are very minor contributors to the total dose.

The full-time resident who would receive the largest annual dose $(0.34 \mathrm{mrem} / \mathrm{y})$ is located approximately $0.8 \mathrm{~km}(0.5 \mathrm{mi})$ north of the site boundary. The major contributor to the whole body dose is the inhalation dose from lead-212 (0.24 mrem/y). If radon-220 and daughters were excluded from the calculation, as required by NESHAP, ${ }^{14}$ the maximally exposed resident would receive a dose of $0.0091 \mathrm{mrem} / \mathrm{y}$, primarily carbon-11 from the IPNS facility (Building 375) and the actinides from Building 350 (NBL).

The individual doses to the maximally exposed member of the public and the maximum fenceline dose is shown in Figure 4.5, while the population dose from 1985 is shown in Figure

4.6. The apparent increases in individual and population doses in 1987 and 1988 are due in part to the peak of the radon-220 emissions from the Proof-of-Breeding Program and also due to changes in the dispersion codes and input parameters.

The population data in Table 1.1 were used to calculate the cumulative population dose from gaseous radioactive effluents from

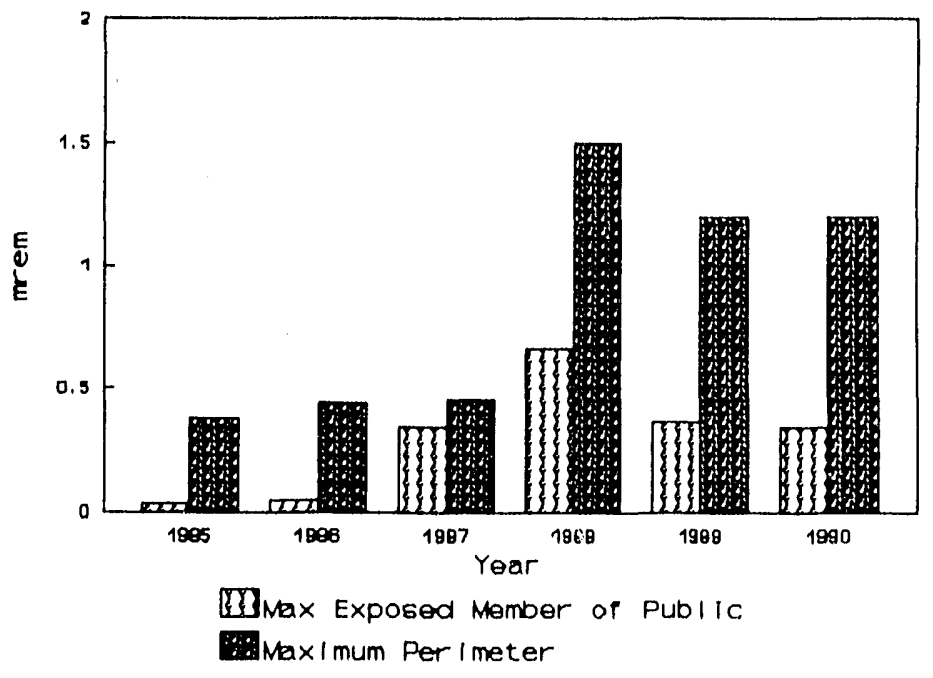

Figure 4.5 Individual and Perimeter Doses From Airborne Radioactive Emissions ANL operations. The results are given in Table 4.31, together with the 
TABLE 4.31

$80-\mathrm{km}$ Population Dose, 1990

\begin{tabular}{|c|c|}
\hline Radionuclide & man-rems \\
\hline Hydrogen-3 & 0.07 \\
\hline Carbon-11 & 0.20 \\
\hline Nitrogen-13 & $<0.01$ \\
\hline 0xygen-15 & $<0.01$ \\
\hline Argon-41 & 0.06 \\
\hline Krypton-85 & $<0.01$ \\
\hline Radon-220 & $<0.01$ \\
\hline Polonium-216 & $<0.01$ \\
\hline Lead-212 & 12.10 \\
\hline Bismuth-212 & 1.24 \\
\hline Tha11 ium-208 & $<0.01$ \\
\hline Radon-222 & $<0.01$ \\
\hline Fluorine-18 & $<0.01$ \\
\hline Antimony-125 & $<0.01$ \\
\hline Lead-210 & $<0.01$ \\
\hline Bismuth-210 & $<0.01$ \\
\hline Polonium-210 & $<0.01$ \\
\hline Uranium-234 & 0.01 \\
\hline Uranium-238 & 0.01 \\
\hline Plutonium-238 & 0.24 \\
\hline Plutonium-239 & 0.30 \\
\hline Plutonium-240 & 0.07 \\
\hline Plutonium-241 & 0.30 \\
\hline Plutonium-242 & $<0.01$ \\
\hline Neptunium-237 & $<0.01$ \\
\hline Americium-241 & 0.45 \\
\hline Americium-243 & $<0.01$ \\
\hline Total & 15.1 \\
\hline Natural & $2.4 \times 10^{6}$ \\
\hline
\end{tabular}


natural external radiation dose. The natural radiation dose listed is the product of the $80-\mathrm{km}(50-\mathrm{mi})$ population and the natural radiation dose of $300 \mathrm{mrem} / \mathrm{y} .{ }^{17}$ It is assumed that this dose is representative of the entire area within an $80-\mathrm{km}(50-\mathrm{mi})$ radius.

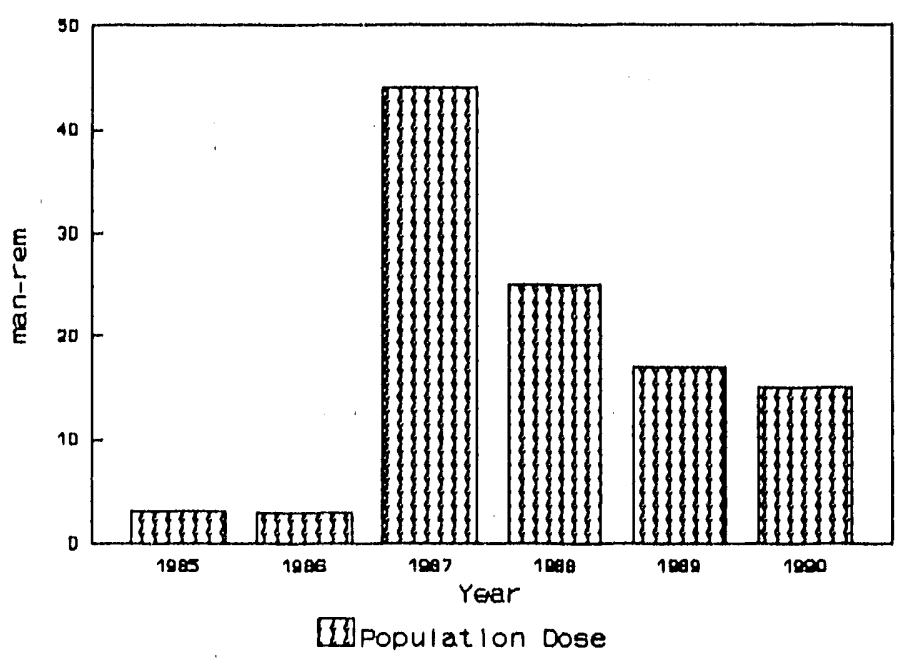

Figure 4.6 Population Dose From Airborne Radioactive Emissions
The potential radiation exposures by the inhalation pathways also were calculated by the methodology specified in DOE Order 5400.5.6 The total quantity for each radionuclide inhaled, in microcuries $(\mu \mathrm{C} i)$, is calculated by multiplying the annual average air concentrations by the general public breathing rate of $8,400 \mathrm{~m}^{3} / \mathrm{y}^{15}$ This annual intake is then multiplied by the CEDE for the appropriate lung retention class. $^{\circ}$ Because the CEDEs are in units of Rem per microcurie (Rem/ $\mu \mathrm{Ci}$ ), this calculation gives the 50-year committed effective dose equivalent. The applicable CEDEs are listed in Table 4.32.

The calculated doses in Tables $4.2,4.3$, and 4.5 were obtained using this procedure. Because they are all essentially at perimeter locations, these doses represent the fenceline values for those radionuclides measured. In most cases, these doses also are the same as the off-site measurements and represent the ambient dose for the area from these nuclides. No doses are calculated for the total alpha and total beta measurements since the guidance does not provide CEDE for such measurements. 
TABLE 4.32

50-Year Committed Effective Dose Equivalent Factors - CEDE $(\operatorname{Rem} / \mu \mathrm{Ci})$

\begin{tabular}{lcc}
\hline Nuclide & Ingestion & Inhalation \\
\hline Hydrogen-3 & $5.3 \times 10^{-5}$ & $6.3 \times 10^{-5}$ \\
Beryllium-7 & - & $2.7 \times 10^{-4}$ \\
Carbon-11 & - & $8.0 \times 10^{-6}$ \\
Strontium-90 & 0.13 & 1.32 \\
Cesium-137 & 0.05 & 0.032 \\
Lead-210 & - & 13.2 \\
Radium-226 & 1.1 & - \\
Thorium-228 & - & 310 \\
Thorium-230 & - & 260 \\
Thorium-232 & - & 1100 \\
Uranium-234 & 0.26 & 130 \\
Uranium-235 & 0.25 & 120 \\
Uranium-238 & 0.23 & 120 \\
Neptunium-237 & 3.90 & - \\
Plutonium-238 & 3.80 & - \\
Plutonium-239 & 4.30 & - \\
Americium-241 & 4.50 & - \\
Curium-242 & 0.11 & - \\
Curium-244 & 2.30 & - \\
Califorium-249 & 4.60 & - \\
Californium-252 & 0.94 & - \\
\hline & & \\
\hline
\end{tabular}




\subsubsection{Water Pathway}

Following the methodology outlined in DOE Order 5400.5, the annual intake of radionuclides (in $\mu C i$ ) ingested with water is obtained by multiplying the concentration of radionuclides in microcuries per milliliter $(\mu \mathrm{C} / \mathrm{mL})$ by the average annual water consumption of a member of the general public $\left(7.3 \times 10^{5} \mathrm{~mL}\right.$.). This annual intake is then multiplied by the CEDE for ingestion (Table 4.32) to obtain the dose recelved in that year. This procedure is carried out for all radionuclides and the individual results are summed to obtain the total ingestion dose.

The only location where radionuclides attributable to ANL operations could be found in off-site water was Sawmill Creek below the waste-water outfa11, see Table 4.6. Although this water is not used for drinking purposes, the 50-year effective dose equivalent was calculated for a hypothet 1 cal individual ingesting water at the radionuclide concentrations measured at that location. Those radionuclides added to Sawmill Creek by ANL waste water, their net concentrations in the creek and the corresponding dose rates (if water at these concentrations were used as the sole water supply by an individual) are given in Table 4.33. The dose rates were all weli below the standards for the general population. It should be emphasized that Sawmill creek is not used for drinking, swimming, or boating. Inspection of the area shows there are fish in the stream, but they do not constitute a significant source of food for any individual. Figure 4.7 is a plot of the total estimated dose an individual would receive if ingesting Sawmill creek water.

As indicated in Table 4.6, occasional Sawmill Creek samples (fewer than ten percent) contained traces of plutonium-238, curium-242,244, or californium-249,252, but the averages were only slightly greater than the detection limit. The annual dose to an individual consuming water at these concentrations can be calculated with the same method used for those radionuclides more commonly found in creek water, but the method of averaging probably overestimates the true concentration. Annual doses range from $3 \times 10^{-3}$ to $6 \times 10^{-5} \mathrm{mrem} / \mathrm{y}$ for these radionuclides. 


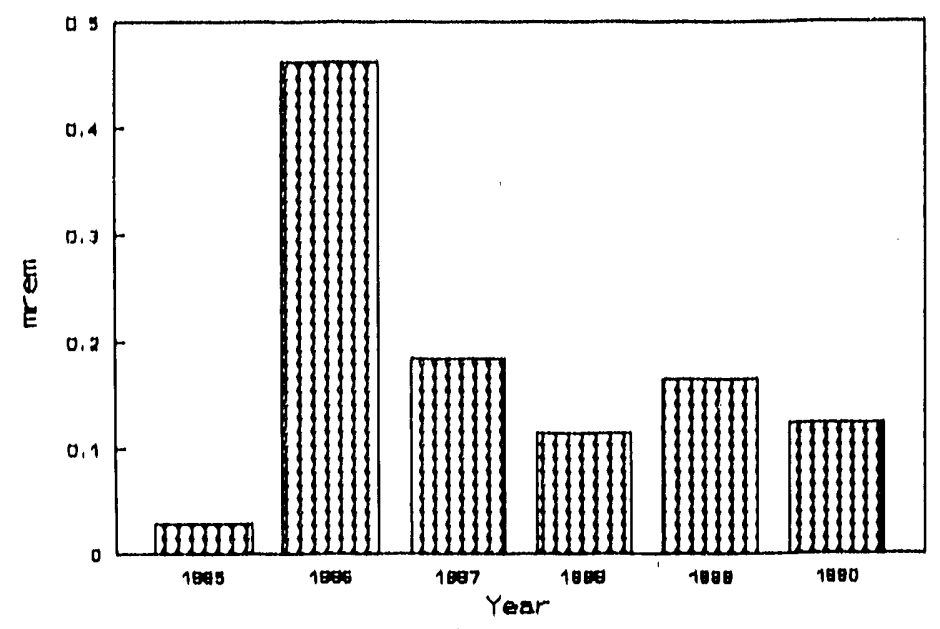

[1]Doge

Figure 4.7 Comparison of Dose Estimates From Ingestion of Sawmill Creek Water

DOE Order $5400.5^{6}$ requires that an evaluation be made of the dose to aquatic organisms from liquid effluents. The dose limit is one $\mathrm{rad} /$ day or $365 \mathrm{rad} / \mathrm{y}$. The location that could result in the higher dose to aquatic organisms is in Sawmill Creek downstream of the point where ANL-E discharges its treated wastewater. Based on inspection of the creek at this location, small bluegill and carp (about $100 \mathrm{~g}$ each) have been observed. Using the annual average concentrations of the radionuclides listed in Table 4.6, a dose can be estimated. The sum of the exposure from these radionuclides is estimated to be about $6.0 \times 10^{-6} \mathrm{rad} / \mathrm{y}$, well within the DOE standard, and therefore demonstrating compliance with that portion of the order.

The EPA has established drinking water standards based on a maximum dose of $4 \mathrm{mrem} / \mathrm{y}$ for man-made beta particle and photon-emitting radionuclides. ${ }^{16}$ The EPA standard is $2 \times 10^{4} \mathrm{pCi} / \mathrm{L}$ for hydrogen-3, $8 \mathrm{pCi} / \mathrm{L}$ for strontium-90, and $200 \mathrm{pCi} / \mathrm{L}$ for cesium-137. The net concentrations in Table 4.33 correspond to $0.0002 \%$ (hydrogen-3), $1.6 \%$ (strontium-90), and $0.14 \%$ (cesium-137) of the EPA standards. No specific EPA standards exist for the transuranic nuclides.

Sawmill Creek flows into the Des Plaines River. The flow rate of Sawmill Creek (see Section 1.6) is about $10 \mathrm{cfs}$, while the flow rate of the Des Plaines River in the vicinity of ANL is about $900 \mathrm{cfs}$. Applying this ratio to the concentration of radionuclides in Sawmill Creek 1 isted in Table 4.33 , the dose to a hypothetical individual ingesting water from the Des Plaines River at Lemont would be about $0.001 \mathrm{mrem} / \mathrm{y}$. Significant additional 
dilution occurs further downstream. Very few people, efther directly or indirectly, use the Des Plaines River as a source of drinking water. If 100 people used Des Platnes River water at the hypothetical concentration at Lemont, the estimated population dose would be about $10^{-4}$ man-rem.

\section{TABLE 4.33}

Radionuclide Concentrations and Dose Estimates for Sawmi11 Creek Water, 1990

\begin{tabular}{lccc}
\hline Radionuclide & $\begin{array}{c}\text { Total Released } \\
\text { (millicurtes) }\end{array}$ & $\begin{array}{c}\text { Net Avg Conc } \\
(\mathrm{pCt} / \mathrm{L})\end{array}$ & $\begin{array}{c}\text { Dose } \\
(\mathrm{mrem} / \mathrm{y})\end{array}$ \\
\hline Hydrogen-3 & 350 & 33 & 0.0015 \\
Strontium-90 & 1.4 & 0.13 & 0.012 \\
Cesium-137 & 3.0 & 0.28 & 0.010 \\
Neptunium-237 & 0.007 & 0.0007 & 0.002 \\
Plutonium-239 & 0.20 & 0.0189 & 0.059 \\
Americium-241 & 0.013 & 0.0120 & 0.039 \\
Sum & & & 0.124 \\
\hline
\end{tabular}

\subsubsection{External Direct Radiation Pathway}

The TLD measurements given in Section 4.6 were used to calculate the radiation dose from external sources. Above-normal fenceline doses attributable to ANL operations were found at the southern boundary near the Waste Storage Facility (Location 7I) and at the northern boundary near Building 202 (Location 14I).

At Location 7I, the net fenceline dose from ANL was about $82 \mathrm{mrem} / \mathrm{y}$. Approximately $300 \mathrm{~m}(0.3 \mathrm{mi})$ south of the fenceline (grid 6I), the measured dose was $82 \pm 2 \mathrm{mrem} / \mathrm{y}$, the same as the normal range of the off-site average $(83 \pm 2 \mathrm{mrem} / \mathrm{y})$. No individuals live in this area. The closest residents are about $1.6 \mathrm{~km}(1 \mathrm{mi})$ south of the fenceline. At this distance, the calculated dose rate from the Waste Storage Facility was $0.01 \mathrm{mrem} / \mathrm{y}$, if the energy of the radiation were that of $0.66 \mathrm{MeV}$ cesium-137 gamma-ray, and about $0.03 \mathrm{mrem} / \mathrm{y}$ if the energy were that of $1.33 \mathrm{MeV}$ cobalt-60 gamma-ray. 
In the area north of the site, the fenceline radiation dose from the cobalt60 sources in Butlding 202 was measured at $13 \mathrm{mrem} / \mathrm{y}$. The nearest residents are $750 \mathrm{~m}(0.47 \mathrm{mi})$ to the north-northwest. The calculated dose at that location was about $0.07 \mathrm{mrem} / \mathrm{y}$.

At the fenceline, where higher doses were measured, the land is wooded and unoccupled. All of these dose calculations are based on full-time, outdoor exposure. Actual exposures to individuals would be substantially less, since some of the individuals are indoors (which provides shielding) or away from their dwellings.

In addition to the permanent residences in the area, occasionally visitors may conduct activities around ANL that could result in exposure to radiation from these sites. Examples of these activities could be cross country skiting, horseback riding, or running in the fire lane next to the perimeter fence. If the individual spent ten minutes per week in these areas, the dose would be $0.08 \mathrm{mrem} / \mathrm{y}$ at the 317 Area fence (location 7I) and $0.01 \mathrm{mrem} / \mathrm{y}$ at location $14 \mathrm{I}$.

\subsubsection{Dose Summary}

The total dose received by off-site residents during 1990 was a combination of the individual doses received through the separate pathways that contributed to exposure: hydrogen-3, carbon-11, nitrogen-13, oxygen-15, argon-41, krypton-85, radon-220 (plus daughters), and actinides through the airborne pathway and cobalt-60 external radiation dose. The highest dose was about $0.41 \mathrm{mrem} / \mathrm{y}$ to individuals living north of the site if they were outdoors at that location during the entire year. The total annual population dose to the entire area within an $80-\mathrm{km}(50-\mathrm{mi})$ radius is $15 \mathrm{man}-\mathrm{rem}$.

To put the maximum individual dose of $0.41 \mathrm{mrem} / \mathrm{y}$ attributable to ANL operations into perspective, comparisons can be made to annual average doses received by the public from natural or accepted sources of radiation. These values are listed in Table 4.34. It is obvious that the magnitude of the doses received from ANL operations is insignificant compared with these sources. Therefore, the monitoring program results establish that the 
radioactive emissions from ANL are very low and do not endanger the health or safety of those living in the vicinity of the site.

TABLE 4.34

\section{Annual Average Dose Equivalent}

in the U. S. Population"

\begin{tabular}{lc}
\hline Source & $\begin{array}{c}\text { Dose } \\
\text { (mrem) }\end{array}$ \\
\hline $\begin{array}{l}\text { Natural Sources } \\
\text { Radon }\end{array}$ & 200 \\
Internal ( ${ }^{40} \mathrm{~K}$ and ${ }^{226} \mathrm{Ra}$ ) & 39 \\
Cosmic & 28 \\
Terrestrial & 28 \\
Medical & 39 \\
Diagnostic X-rays & 14 \\
Nuclear Medicine & \\
Consumer Products & 10 \\
Domestic Water Supplies, & \\
Building Materials, etc. & 1 \\
Occupational (medical & \\
radiology, industrial & \\
radiography, research, etc.) & $<1$ \\
Nuclear Fuel Cycle & $<1$ \\
Fallout & $<1$ \\
Other Miscellaneous Sources & 360 \\
\hline
\end{tabular}

NCRP Report No. 93. ${ }^{17}$ 


\section{ENVIRONMENTAL NONRADIOLOGICAL PROGRAM INFORMATION}

The nonradiological monitoring program involves the collection and analysis of surface water and groundwater samples from numerous locations throughout the site. The release of nonradiological pollutants to the air from ANL is extremely small, except for the botler house, which is equipped with dedicated monitoring equipment. As a result, the ambient air is not routinely monitored. Chapter 3 discusses the entire environmental monitoring program in more detail.

Surface water samples for nonradiological chemical analyses are collected from NPDES permitted outfal1s, Sawmill Creek, and the Des Plaines River. Analyses conducted on the samples from the NPDES outfalls vary depending on the permit-mandated monitoring requirements for each outfall. The results of the analyses are compared with the permit limits for each outfall to determine whether they comply with the permit. Besides being published in this report, the NPDES monitoring results are transmitted monthly to the IEPA in an official Discharse Monitoring Report (DMR). A summary of exceedances of permit limits during 1990 appears in Table 5.1

In addition to the permit-required monitoring, samples of water from Sawmill creek and the Des Plaines River are collected and analyzed for a number of inorganic constituents. Additional analyses are also conducted on samples collected from the combined wastewater outfall (NPDES outfall 001) to provide a more complete evaluation of the impact of the wastewater on the environment. The results of this additional analysis of the main outfall and receiving streams are then compared with IEPA General Effluent Standards and Stream quality Standards listed in the IAC, Title 35, Subtitle C, Chapter I. ${ }^{18}$

\subsection{National Pollutant Discharge Elimination System Monitoring Results}

Wastewater is processed at ANL in two independent systems, the sanitary system and the laboratory system. The sanitary wastewater collection and treatment system collects wastewater from lavatories, the cafeteria, office buildings, and other portions of the site which do not contain radioactive 
TABLE 5.1

NPDES Permit Limit Exceedances, 1990

\begin{tabular}{clc}
\hline Outfa11 & Parameter & Number of Exceedances \\
\hline \multirow{2}{*}{001} & Total Dissolved Solids & 55 \\
& Chloride & 8 \\
$001 B$ & BOD & 3 \\
& Total Suspended Solids & 1 \\
003 & Total Suspended Solids & 2 \\
004 & Total Suspended Solids & 2 \\
006 & Total Suspended Solids & 3 \\
& pH & 2 \\
010 & pH & 2 \\
& Total Suspended Solids & 3 \\
& Iron & 3 \\
& Zinc & 1 \\
& Manganese & \\
\hline
\end{tabular}

or hazardous materials. This wastewater is treated in a biological wastewater treatment system consisting of primary clarifiers, trickling filters and slow sand filters. Wastewater generated by research-related activities, such as laboratories and experimental equipment, flows to a series of retention tanks located in each bullding. When a retention tank is full, a sample is collected and analyzed for radioactivity. If the wastewater is found to be suitable for discharge, it is pumped to the laboratory wastewater collection system, which directs the flow to the laboratory wastewater treatment system. This system consists of a serles of concrete holding tanks which collect the wastewater prior to discharge. As with the retention tanks, once a holding tank is full, it is sampled and analyzed for radioactivity. If the level of radioactivity is below ANL discharge criteria, which were selected to ensure compliance with DOE orders, it is pumped to a lined equalization basin, slowly discharged to the chlorine contact tank and then to Sawinill creek. If either a retention tank or holding tank is found to contain unacceptable levels of radioactivity, the wastewater is pumped into portable tanks, treated by evaporation in Building 
306 and the residue is disposed of as radioactive waste. Figure 5.1 shows the two wastewater treatment systems ihat are located adjacent to each other. The volume of wastewater discharged from these facilities averaged 3.9 million liters per day ( 1.03 million gallons per day) and was composed of $55 \%$ sanitary waste water and $45 \%$ laboratory process wastewater. The equalization basin was out of service through most of 1990 due to maintenance problems with the liner. It was returned to service in October 1990 and is currently functioning normally.

These two systems process the vast majority of wastewater generated by ANL. However, a small amount of process wastewater, primarily cooling tower blowdown and cooling water, is discharged directly to a number of small streams and ditches throughout the site. This wastewater does not contain significant amounts of contaminants and does not require treatment before discharge. However, these discharge points are included in the site NPDES permit as separate regulated outfalls.

ANL processed wastewater discharges are regulated by NPDES Permit No. IL $0034592 .{ }^{19}$ As discussed in Section 3.2.1., this permit was renewed on July 7, 1989, and expires on January 15, 1994. Nine surface water discharge points (outfalls) and two internal monitoring points are included in this permit. The analyses required and the frequency of analysis for each point are specified in the permit. The analytical methods required for NPDES monitoring are listed in Table $1 B$ of 40 CFR Part $136 .{ }^{20}$ Sample collection, preservation, and holding times are also mandated by requirements stipulated in Table 2 of 40 CFR Part $136^{20}$.

The NPDES outfall locations are shown in Figure 5.2. To improve the clarity of this figure, the outfall numbers are shown without the leading zeroes. Thus, outfall 001A is shown as 1A. Outfalls 001A and 001B, the two internal monitoring points representing the effluent from the sanitary system and laboratory system, respectively, are both located at the wastewater treatment facility. Their flows combine to form outfall 001 which is also located at the treatment facility. The combined stream flows through an outfall pipe which discharges into Sawmill creek approximately 1100 meters ( 3500 feet) south of the treatment plant. 


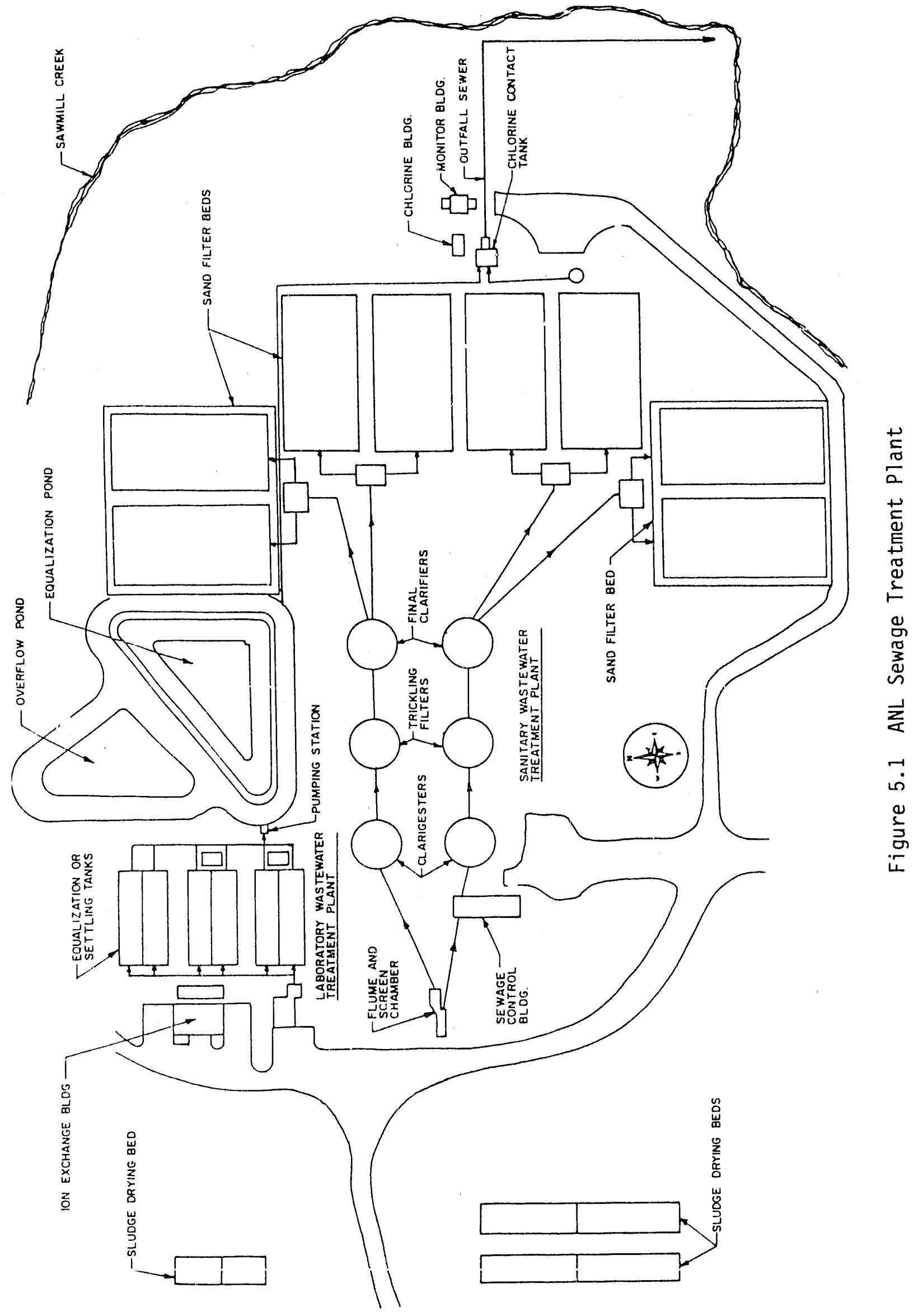




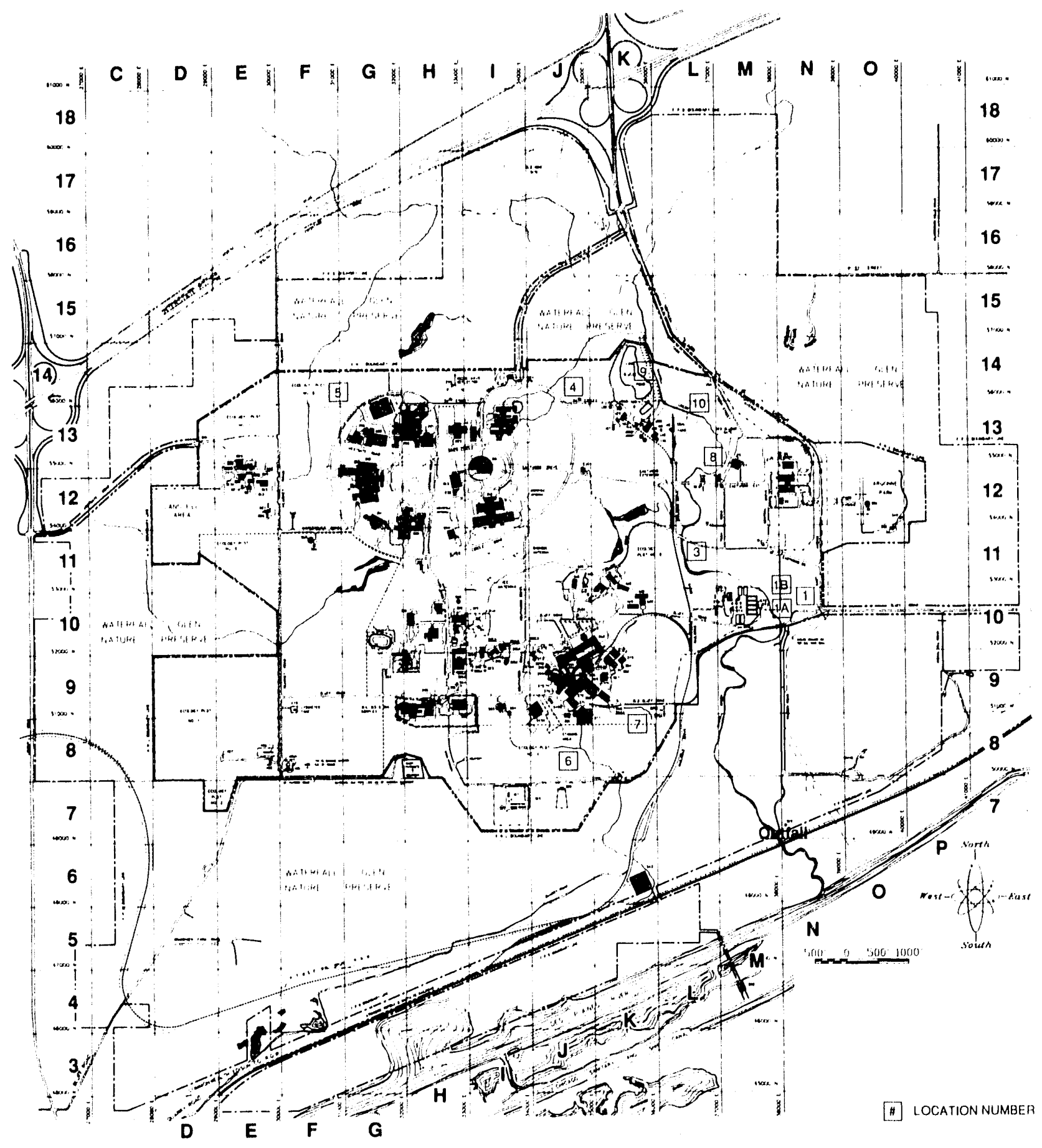

rigure 5.2 NPDES Outfall Locations 


\subsubsection{Sample Collection}

NPDES samples are collected by ANL's Environment, Safety and Health Division (ESH) personnel, with the exception of samples from locations $001 \mathrm{~A}$. and 001B, which are collected by Plant Facilities and Services Division (PFS) personnel. All samples are collected using specially cleaned and labelled bottles with appropriate preservatives added. Custody seals and chain-of-custody sheets are also used. All samples are analyzed within the required holding time. Samples are collected at locations 001, 001A and $001 B$ on a weekly basis. Samples are collected at the other locations on a monthly basis.

\subsubsection{Results}

During 1990, approximately $91 \%$ of all NPDES analyses were below their applicable permit limits. Specific limit exceedances are discussed later in this section as well as in Chapter 2. A discussion of the analytical results for each outfall follows.

Outfall 001

The treated wastewater streams from the two treatment systems are combined, following chlorine addition, and samples for analysis of most of the permit parameters are collected from a manhole downstream of the chlorine contact chamber. This manhole is outfall 001 . The combined effluent then flows through the outfall sewer towards Sawmill creek. The effluent is travels through this sewer for approximately 20 minutes before being discharged. The time the chlorinated wastewater resides within this sewer pipe, before mixing with Sawmill creek, increases the effectiveness of the chlorine added at the treatment plant. The samples used for determination of fecal coliform bacteria are collected at the outlet of this pipe to take this effect into account. The disinfection of ANL ivastewater was successful in 1990, resulting in no violations of fecal coliforii limits.

The disposal of water softener brine solutions results in an effluent with high levels of TDS and chloride. The permit requires analysis of the 
combined effluent twice per month for TDS, chloride and sulfate. The 1 imit for TDS is $1040 \mathrm{mg} / \mathrm{L}$, for chloride it is $550 \mathrm{mg} / \mathrm{L}$ and for sulfate it is 575 $\mathrm{mg} / \mathrm{L}$. The limit for TDS was exceeded in every sample collected in 1990, except for one collected in october. The limit for chloride was exceeded primarily in the winter and fall months. The sulfate limit was never exceeded. Figure 5.3 shows the results of TDS and chloride analysis for 1990. The decrease in TDS and chloride concentrations from winter to spring and summer reflects the greatly reduced demand for softened water resulting from reduced steam generation for space heating.

An effort was made in August to lower the levels of TDS and chloride in the effluent by reducing the finished water softness, thus decreasing the sodium chloride use and disposal. This measure was partly successful in reducing TDS and chloride levels, but the permit limits were still being exceeded. In September water softening was eliminated altogether. This move was successful in bringing the chloride levels temporarily into compliance, but the TDS levels were still excessive. As winter approached, the softened water usage at the boiler house increased, causing increased salt usage and increases in TDS and chlorides. To prevent damage to the boilers and other laboratory systems, the softening process was changed again, returned it to about $50 \%$ of normal levels. The levels of TDS returned to previous levels as shown in Figure 5.3. An ANL Task Force appointed to study this problem concluded that effluent limits could not be achieved by changes to the existing system and that an alternative disposal mechanism for the brines was needed. Construction of a new sewer which would direct the brines to a DuPage County wastewater treatment plant was proposed. ANL, in cooperation with DOE, IEPA, and DuPage County, agreed to construct this new sewer. In addition, the Task Force recommended the use of Lake Michigan water, which does not require softening, once it becomes available to neighboring communities in 1992. The use of this water would eliminate most of the on-site water softening.

The permit requires that a biological toxicity screening test be performed at location 001 in June of each year (the same time that the sampling for priority pollutants at outfall 001B, discussed later, is performed). The toxicity testing is run on at least three trophic levels of aquatic 


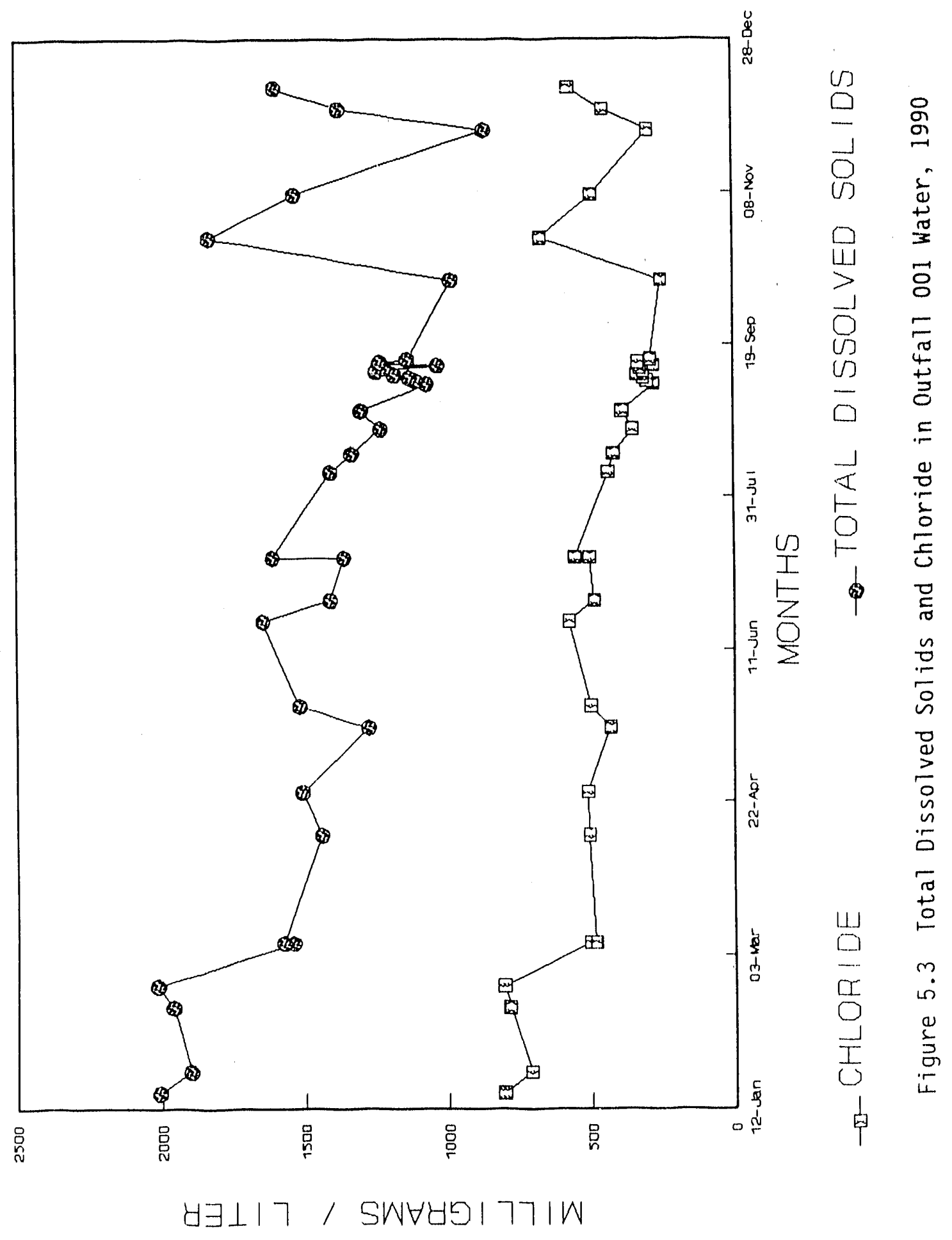


species for both chronic and acute toxicity. The 1990 testing was several weeks late, being performed on samples collected in July, approximately three weeks after collection of the priority pollutant samples at outfall 001B. The testing was preformed using a water flea, Ceriodaphnia dubia, a fat head minnow, Pimephales promelas, and a green alga, Selenastrum capricornutum. The EPA protocol, as modified by the IEPA, was used for this test.

No acute toxicity was demonstrated in these tests. Some slight chronic toxicity was found using the water flea and alga tests, but no chronic toxicity was observed with the fathead minnow tests.

The permit also requires that weekly $\mathrm{pH}$ measurements be made. There were no violations of the $\mathrm{pH}$ limits of 6-9 $\mathrm{pH}$ units during 1990.

\section{Outfal1 001A}

This outfall is composed of treated sanitary wastewater and various wastewater streams from the boiler house area, including coal pile stormwater runoff. The effectiveness of the sanitary wastewater treatment system is evaluated by weekly monitoring for Biochemical oxygen Demand (BOD), pH, and total suspended solids. The limits for five-day BOD are a monthly average of $10 \mathrm{mg} / \mathrm{L}$ with a maximum value of $20 \mathrm{mg} / \mathrm{L}$. The permit limits for total suspended solids are a maximum concentration of $24 \mathrm{mg} / \mathrm{L}$ and a monthly average of $12 \mathrm{mg} / \mathrm{L}$. The $\mathrm{pH}$ must range between values of 6 and 9 . There were no exceedances of any of these 1 imits at outfall $001 \mathrm{~A}$.

The permit requires weekly monitoring for chromium, copper, iron, lead, manganese, zinc, and $0 i 1$ and grease. The effluent limits for these parameters are shown in Table 5.2. There are two limits listed, one a maximum limit for any single sample and the other for the average of all samples collected during the month. These constituents are present in the coal pile runoff. All samples collected and analyzed for these parameters were within the permit limits during 1990. A listing of the results appears in Table 5.2. The average shown in the table is the annual average for each constituent. 
TABLE 5.2

Outfa11 001A Effluent Limits and Monitoring Results, 1990 (Concentrations in $\mathrm{mg} / \mathrm{L}$ )

\begin{tabular}{|c|c|c|c|c|c|}
\hline Constituent & Minimum & Maximum & Average & $\begin{array}{c}\text { Average } \\
\text { Limit }\end{array}$ & $\underset{\text { Limit }}{\text { Maximum }}$ \\
\hline Chromium & - & - & $<0.02$ & 1.00 & 2.00 \\
\hline Copper & $<0.01$ & 0.42 & 0.06 & 0.50 & 1.00 \\
\hline Iron & $<0.1$ & 2.8 & 0.33 & 2.00 & 4.00 \\
\hline Lead & - & - & $<0.10$ & 0.20 & 0.40 \\
\hline Manganese & 0.01 & 0.11 & 0.05 & 1.00 & 2.00 \\
\hline Zinc & 0.03 & 0.37 & 0.14 & 1.00 & 2.00 \\
\hline $0 i 1$ \& Grease & - & - & $<5$ & 15.0 & 30.0 \\
\hline
\end{tabular}

Outfal1 001B

This outfall consists of treated wastewater from the laboratory wastewater treatment system. The permit requires that weekly samples be collected and analyzed for BOD, Total suspended Solids (TSS), mercury, and Chemical Oxygen Demand (COD).

The limits established for BOD are a daily maximum of $20 \mathrm{mg} / \mathrm{L}$ with a 30 -day average of $10 \mathrm{mg} / \mathrm{L}$. The permit also contain mass loading limits of $114 \mathrm{lbs} /$ day as a daily maximum and $57 \mathrm{lbs} /$ day as a 30-day average. The mass loading represents the weight of material discharged per day and is a function of concentration and flow. Samples obtained in April and May exceeded the concentration levels, but only the May sample exceeded the loading limit.

The daily maximum limit for TSS is $24 \mathrm{mg} / \mathrm{L}$ with a 30-day average of 12 $\mathrm{mg} / \mathrm{L}$. The mass loading limits are 136 and $68 \mathrm{lbs} /$ day, respectively. There was one violation of concentration limit for TSS at this location in June. This value did not exceed the loading limit. 
The dafly maxtmum concentration 1 imit for mercury is $6 \mu \mathrm{g} / \mathrm{L}$ and the 30 day average is $3 \mu \mathrm{g} / \mathrm{L}$. The corresponding loading values are $0.034 \mathrm{lbs} / \mathrm{day}$ and $0.017 \mathrm{lbs} /$ day. There were no violations in 1990 of etther $1 \mathrm{fm}$ t.

There are no concentration limits established for COD. The once-perweek grab samples give a rough indication of the organic content of this stream. The values obtained in 1990 ranged from $<20 \mathrm{mg} / \mathrm{L}$ to $600 \mathrm{mg} / \mathrm{L}$.

There is a special condition for location 001B that requites the monitoring for the 126 prority pollutants, 1isted in the permit, during the months of June and December. The June sampling is to be conducted at the same time that aquatic toxicity testing of outfall 001 is conducted. In addition to the typical 1ist of priority pollutants, fibrous asbestos and 2,3,7,8-tetrachlorodibenzo-p-dioxin (commonly called dioxin) are to be determined. Samples were collected on June 19, 1990, and December 12, 1990, and analyzed within the required holding times.

Analysis of these samples indicated that very small amounts of a few chemicals were present. The results for semivolatile organic compounds, PCBs and pesticides were all less than the detection limits. The results for metals were similar to concentrations found in ANL treated drinking water. The samples contained several volatile organic compounds at very low levels. The majority of compounds found are halomethanes commonly found in chlorinated drinking water and are thought to result from on-site treatment of the water supply. In addition, low levels of chloroform, 1,1,-dichloroethane, 1,1,1-trichloroethane, trichloroethene, and toluene were found. The analytical report from the June sample contains results for a slightly longer list of volatile organic carbon compounds than just those contained on the priority pollutant list. For this sample acetone and bromodichloromethane, neither of which is included on the priority pollutant 1ist, were determined to be present. The December sample analysis report contained results for only the listed priority pollutants, and thus results for these two compounds were not included. The concentrations of volatile organics identified in these samples are contained in Table 5.3. While there are currently no permit limits or effluent standards for these compounds with which to compare these results, the concentrations found are believed to be of little 
concern because they are below acceptable standards for drinking water supplies, where such standards exist.

TABLE 5.3

Outfal1 001B Volatfle Organic Carbon Monitoring Results, 1990 (Concentrations in $\mu \mathrm{g} / \mathrm{L}$ )

\begin{tabular}{lcc}
\hline Compound & $\begin{array}{c}\text { Concentration in } \\
\text { June Sample }\end{array}$ & $\begin{array}{c}\text { Concentration in } \\
\text { December Sample }\end{array}$ \\
\hline Acetone & $340(1)$ & Not analyzed \\
Bromodichioromethane & $2(1)$ & Not analyzed \\
Chloroform & 4 & 23 \\
Dibromochioromethane & 3 & 5 \\
Methylene chioride & 1 & 28 \\
Toluene & Not detected & 3 \\
1,1,1 Trichloroethane & 3 & Not detected \\
Trichloroethene & 2 & Not detected
\end{tabular}

(1) These compounds are not contained on the priority pollutant list, however they were determined to be present in the June sample.

Results for the June sample for asbestos showed no fibers detected. The December sample indicated a concentration of asbestos structures of 33.8 million structures per 1 iter, all of which were less than $10 \mu \mathrm{m}$ in length. Neither of the samples had detectable levels of dioxin.

The laboratory wastewater treatment system consists of six 69,000 gallon holding tanks (see Figure 5.1) which are pumped to a lined equalization pond before being discharged to Sawmill creek. During 1989, a study was performed to determine the levels of volatile organic compounds in the influent to these tanks and to determine the variability of this concentration. A number of different volatile organics were found to be present from time to time, with the concentration varying greatly throughout the day. Maximum levels were found to occur in the late afternoon. As a followup to this study, each month one influent sample is obtained at about 1300 hours and analyzed for volatile organic compounds. The results for the most 
common compounds found are shown in Table 5.4. In addition to the se compounds, most samples contained very low concentrations of bromodichloromethane, chlorodibromomethane, and, in some cases, bromoform. These halomethanes, at the levels found, including some of the chloroform results, are thought to be due to the chlorination of the water supply. Chloroform levels above approximately $10 \mu \mathrm{g} / \mathrm{L}$ are probably due to other causes.

TABLE 5.4

Volatile Organic Compounds in Laboratory Wastewater, 1990 (Concentrations in $\mu \mathrm{g} / \mathrm{L}$ )

\begin{tabular}{lcccc}
\hline Month & Acetone & Benzene & Chloroform & $\begin{array}{l}\text { Methylene } \\
\text { Chloride }\end{array}$ \\
\hline January & 119 & $<5$ & $<5$ & $<5$ \\
February & 175 & 6 & 7 & $<5$ \\
March & $<10$ & $<5$ & 26 & $<5$ \\
Apri1 & 2900 & $<5$ & 178 & 781 \\
May & 4770 & $<5$ & 19 & $<5$ \\
June & 4 & $<5$ & 4 & $<5$ \\
July & 6 & $<5$ & 21 & $<5$ \\
August & $<10$ & $<5$ & 3 & $<5$ \\
September & 45 & $<5$ & 6 & $<5$ \\
October & 23 & $<5$ & 7 & $<5$ \\
November & $<10$ & $<5$ & 6 & $<5$ \\
December & $<10$ & $<5$ & 6 & $<5$ \\
& & & &
\end{tabular}

Table 5.4 indicates that acetone is frequently found in the influent over a large concentration range. Chloroform on at least four occasions is higher than would be expected from water treatment. In April, a relatively high concentration of methylene chloride was detected. These results may not be representative of the average wastewater composition because the samples were collected at a time when the concentrations were expected to be at their highest. 


\section{Outfa11 003}

This outfall is the discharge point from a series of small man-made ponds and is composed primartly of stormwater, with small amounts of process wastewater, such as cooling tower blowdown. It is sampled monthly and analyzed for pH, TSS and temperature. Permit 1 imits exist for TSS (15 mg/L average and $30 \mathrm{mg} / \mathrm{L}$ maximum), $\mathrm{pH}$ (between 6 and $9 \mathrm{pH}$ units) and temperature (less than $5^{\circ} \mathrm{F}$ temp. rise). During 1990, there were two violations of TSS limits. These and past TSS violations are probably due to excessive siltation that has occurred over the years. Plans are being developed to dredge the excess sediment from these ponds to improve the effluent TSS levels. No other limits were exceeded.

\section{Outfa11 004}

Outfall 004 consists primarily of stormwater with small amounts of cooling water from Building 202. The sampling requirements and effluent 1 imits are the same as those for location 003 . There were two violations of TSS limits in 1990. This outfall has a history of frequent TSS violations. Most of the violations are thought to be caused by erosion of soll from the surrounding area during heavy precipitation. Corrections of soil erosion problems throughout the site are currently being developed.

\section{Outfal1 005}

This outfall consists of stormwater and process wastewater from the Building 206 cooling system and the 800 Area, which includes vehicle and other maintenance areas. The permit requirements include monthly sampling and analysis for $0 i 1$ and grease, $\mathrm{pH}$, and temperature. Limits of $15 \mathrm{mg} / \mathrm{L}$ average and $30 \mathrm{mg} / \mathrm{L}$ maximum exist for 011 and grease. The $\mathrm{pH}$ and TSS 1 imits are the same as for outfall 003 . There were no violations in 1990.

Outfal1 006

This outfall consists of stormwater, cooling tower blowdown and overflow from settling ponds used at the Canal Water Treatment Plant. The 
permit requtres monthly sampling for $\mathrm{pH}$, TSS, and temperature. The 1 imtts are the same as for outfall 003 . In 1990 there were three violations of the TSS $1 \mathrm{imit}$. These results ranged from 79 to $450 \mathrm{mg} / \mathrm{L}$ (permit $1 \mathrm{imtt} 30$ ) and were caused by the discharge of sludge from the settling ponds as a result of heavy prectpitation and poor maintenance of the ponds. In addition, there were two violations of the pH limtts. pH values of 10.2 and 10.4 were obtained which exceeded the upper $1 \mathrm{imit}$ of 10 . Upon investigation of the $\mathrm{pH}$ 1 imit exceedances, it was determined that spent regeneration solutions from an ton exchange water treatment devtce located in Butlding 365 were being discharged to floor drains whtch discharge to a storm sewer upstream of outfall 006, causing the pH fluctuations. This practice has been discontinued.

Outfa11 007

Outfall 007 consists of stormwater and Building 360 cooling water. It is to be sampled monthly and analyzed for $\mathrm{pH}$ and temperature. The effluent limits are the same as for the other outfalls. Samples were obtained for the first three quarters of the year and all parameters met the effluent limitations. The stream was dry in the last quarter of the year, and, as a result, no sample was collected.

\section{Outfall 008}

Outfall 008 consists of uncontaminated stormwater runoff from the East Area. The only permit limit that applies at this point is $\mathrm{pH}$, as described elsewhere. There is normally no flow from this outfal1. An attempt to sample this point is made each month. If water is found to be flowing, a sample is collected and analyzed. During 1990, no samples were collected.

\section{Outfa11 009}

This outfall is an emergency overflow for an inactive lime sludge lagoon near the water treatment plant. This lagoon has not been used since 1986. Accumulated rainwater is periodically pumped to the sanitary wastewater treatment system to prevent overflow of the alkaline water. In 
the event that an extremely heavy storm occurs, rainwater could flow out of this outlet. The permit contains limtts for pH and TSS, which are the same as for outfall 003. The permit requires monttoring monthly, when discharge is occurring. There was no such discharge during 1990.

\section{Outfarl 010}

This location is an emergency overflow point for the diked coal plle storage area. It discharges only under conditions of heavy rain and prevents flooding of the coal ptle area. This outfall is sampled nnce per month when flow occurs. Analyses are performed for $\mathrm{pH}$, total suspended solids, tron, lead, zinc, manganese, total chromium, copper, and 011 and grease. The permit limits for these parameters are shown in Table 5.5.

Flow occurred at this site during July and November 1990. As required, samples were collected and analyzed. The results are shown in Table 5.5. The July sample exceeded the monthly average limits for $\mathrm{pH}$, TSS, iron, zinc, and manganese. In addition the iron result exceeded the maximum limit. The November sample exceeded the permit limits for $\mathrm{pH}$. TSS and iron values exceeded both the maximum and average limits.

\section{TABLE 5.5}

Outfall 010 Effluent Limits and Monitoring Results, 1990 (Concentrations are $\mathrm{mg} / \mathrm{L}$, except for $\mathrm{pH}$ )

\begin{tabular}{lcccc}
\hline Constituent & $\begin{array}{c}\text { July } \\
\text { Results }\end{array}$ & $\begin{array}{c}\text { November } \\
\text { Results }\end{array}$ & $\begin{array}{c}\text { Average } \\
\text { Limit }\end{array}$ & $\begin{array}{c}\text { Maximum } \\
\text { Limit }\end{array}$ \\
\hline Chromium & $<0.02$ & $<0.02$ & 1.0 & 2.0 \\
Copper & 0.2 & 0.08 & 0.5 & 1.0 \\
Iron & 202 & 45 & 2.0 & 4.0 \\
Lead & $<0.1$ & $<0.1$ & 0.2 & 0.4 \\
Manganese & 1.2 & 0.7 & 1.0 & 2.0 \\
Oi1 \& Grease & $<5$ & $<5$ & 15 & 30 \\
pH & 2.7 & 3.4 & $6-9$ & $6-9$ \\
Zinc & 1.8 & 0.9 & 1.0 & 2.0 \\
\hline
\end{tabular}




\subsection{Additional Effluent Monitoring}

To more fully characterize the wastewater from the ANL site, composite samples of the combined effluent are collected each week and analyzed for the constituents shown in Table 5.6. The results are then compared to the IEPA General Effluent limits found in 35 IAC, Subtitle C, Part 304.

\subsubsection{Sample Collection}

Samples for analysis of inorganic constituents are collected daily from outfall 001 located at the Waste Water Treatment Plant using a refrigerated time proportional sampler. A portion of the sample is transferred to a specially cleaned bottle, a security seal is affixed and chainof-custody is maintained. Five daily samples are composited on an equal volume basis to produce a weekly sample, which is then analyzed.

\subsubsection{Results}

The results for 1990 appear in Table 5.6. The values are similar to results reported in previous years. The only constituents found in significant concentrations were mercury and silver. Elevated levels of mercury were seen occasionally and were probably due to residual mercury contamination in the laboratory sewage collection system. Silver has been detected on occasion at very low levels. Its presence is thought to be caused by discharges from several film processing operations. Both constituents were well below the General Effluent Limits.

\subsection{Sawmill Creek}

Sawmill Creek is a small natural stream that is fed primarily by stormwater runoff. During periods of low precipitation, the creek above ANL has a very low flow. At these times, a major portion of the water in Samil11 Creek south of the site consists of ANL wastewater and discharges to assorted storm drains. To determine the impact ANL wastewaters have on Sawmill creek, samples of the creek downstream of all ANL discharge points 
TABLE 5.6

Chemical Constituents in Effluents From ANL Wastewater Treatment Plant, 1990 (Concentrations in $\mathrm{mg} / \mathrm{L}$ )

\begin{tabular}{lccccc}
\hline Constituent & $\begin{array}{c}\text { No. of } \\
\text { Samples }\end{array}$ & Avg. & $\begin{array}{c}\text { Concentration } \\
\text { Min. }\end{array}$ & Max. & Limit \\
\hline Arsenic & 51 & 0.0034 & $<0.0025$ & 0.0250 & 0.25 \\
Barium & 51 & 0.0678 & 0.0075 & 0.1668 & 2.0 \\
Beryllium & 51 & 1.33 & $<0.20$ & 5.00 & - \\
Cadmium & 51 & 0.0017 & 0.0003 & 0.0050 & 0.15 \\
Chromium & 51 & 0.0068 & $<0.0040$ & 0.0200 & 1.0 \\
Cobalt & 51 & 0.035 & $<0.030$ & 0.050 & - \\
Copper & 51 & 0.049 & 0.017 & 0.141 & 0.5 \\
Fluoride & 12 & 0.368 & 0.280 & 0.520 & 15.0 \\
Iron & 51 & 0.335 & 0.147 & 1.843 & 2.0 \\
Lead & 51 & 0.0074 & $<0.0020$ & 0.1160 & 0.2 \\
Manganese & 51 & 0.049 & $<0.015$ & 0.111 & 1.0 \\
Mercury & 52 & 0.2 & $<0.1$ & 2.2 & 0.5 \\
Nickel & 51 & 0.034 & $<0.003$ & 0.062 & 1.0 \\
Selenium & 13 & - & - & $<0.0050$ & - \\
Silver & 51 & 0.0032 & $<0.0005$ & 0.0100 & 0.1 \\
Thallium & 51 & - & - & $<0.010$ & - \\
Vanadium & 51 & 0.025 & $<0.015$ & 0.063 & - \\
Zinc & 51 & 0.114 & $<0.010$ & 0.249 & 1.0 \\
pH (Units) & 253 & - & 7.3 & 8.3 & $6.0-9.0$ \\
& & & & & \\
\hline
\end{tabular}

Units $=\mu \mathrm{g} / \mathrm{L}$ 
are collected and analyzed. The results are then compared to the IEPA Water Quality Standards.

\subsubsection{Sample collection}

Grab samples are collected daily at a point well downstream of the combined wastewater discharge point where thorough mixing of the ANL effluent and Sawmill creek water is assured. Samples are collected in precleaned, labelled bottles and security seals are used. After pH measurement, the daily samples are combined into weekly samples and the resulting solutions are preserved by acidification.

\subsubsection{Results}

The results obtained are shown in Table 5.7. Four constituents, copper, irc.l, mercury, and silver, were above Water Quality Standards on at least one occasion. The annual average concentrations for copper and iron were above the standards as well.

\subsection{Des Plaines River}

Based on previous sampling results, it was determined that mercury would be the only compound likely to have a measurable impact on the Des Plaines River. The effect of Sawmill creek on the levels of mercury in the Des Plaines River was evaluated by collecting samples in the river at Willow Springs (upstream of ANL) and at Lemont (downstream of ANL). All of the samples analyzed showed that the total mercury concentration was less than the detection limit of $0.1 \mu \mathrm{g} / \mathrm{L}$. 
TABLE 5.7

Chemical Constituents in Sawmill Creek, Location 7M," 1990 (Concentrations in $\mathrm{mg} / \mathrm{L}$ )

\begin{tabular}{|c|c|c|c|c|c|}
\hline Constituent & $\begin{array}{l}\text { No. of } \\
\text { Samples }\end{array}$ & Avg. & $\begin{array}{l}\text { Concentration } \\
\text { Min. }\end{array}$ & $\operatorname{Max}$ & Limit \\
\hline Arsenic & 51 & 0.0025 & $<0.0025$ & 0.0030 & 1.0 \\
\hline Barium & 51 & 0.0869 & 0.0380 & 0.2481 & 5.0 \\
\hline Beryllium"* & 51 & 1.33 & $<0.20$ & 5.00 & - \\
\hline Cadmium & 51 & 0.0019 & 0.0003 & 0.0050 & 0.05 \\
\hline Chromium & 51 & 0.0066 & $<0.0040$ & 0.0257 & 1.0 \\
\hline Cobalt & 51 & 0.035 & $<0.030$ & 0.050 & - \\
\hline Copper & 51 & 0.027 & $<0.010$ & 0.069 & 0.02 \\
\hline Fluoride & 12 & 0.267 & 0.186 & 0.444 & 1.4 \\
\hline Iron & 51 & 1.152 & 0.239 & 4.300 & 1.0 \\
\hline Lead & 51 & 0.0090 & $<0.0020$ & 0.0880 & 0.1 \\
\hline Manganese & 51 & 0.061 & 0.018 & 0.134 & 1.0 \\
\hline Mercury"* & 52 & 0.2 & $<0.1$ & 1.0 & 0.5 \\
\hline Nickel & 51 & 0.033 & $<0.003$ & 0.070 & 1.0 \\
\hline Selenium & 13 & - & - & $<0.0050$ & 1.0 \\
\hline Silver & 51 & 0.0031 & $<0.0005$ & 0.0100 & 0.005 \\
\hline Tha1lium & 51 & - & - & $<0.010$ & - \\
\hline Vanadium & 51 & 0.023 & $<0.015$ & 0.059 & - \\
\hline Zinc & 51 & 0.066 & 0.017 & 0.480 & 1.0 \\
\hline $\mathrm{pH}$ (Units) & 244 & 8.0 & 7.1 & 8.4 & $6.5-9.0$ \\
\hline
\end{tabular}

Location $7 M$ is $15 \mathrm{~m}(50 \mathrm{ft})$ downstream from the ANL wastewater outfall. "Units $=\mu \mathrm{g} / \mathrm{L}$. 


\section{GROUNDWATER PROTECTION}

The groundwater below the ANL site is monitored through the collection and analysis of samples obtained from the on-site water supply wells and from a series of groundwater monitoring wells located near several sites which have the potential for causing groundwater impact. Except for the drinking water, there are no limits or other numeric criteria to evaluate groundwater quality. To determine if an adverse impact to the groundwater has occurred, concentration data is compared against data from control samples collected in areas known to be uncontaminated.

\subsection{Potable Water System}

The ANL domestic water is supplied by four wells. The wells are described in Section 1.5 and their locations are shown in Figure 1.1. According to the National Primary Drinking Water Regulations, Argonne's system is classified as a non-transient, non-community water system, ${ }^{16}$ since it regularly serves at least 25 of the same persons over six months of the year. This designation determines the parameters to be monitored and the frequency of monitoring.

The ANL water supply was monitored regularly and the results are compared with applicable State and Federal drinking water standards. Samples from each well were collected quarterly at the wellhead and a sample of the

finished water was collected annually. These samples were analyzed for several types of radioactive constituents. Additional samples were collected by ANL's Plant Facilities and Services Division and analyzed by a outside laboratory for the chemical constituents listed in Table 6.1.

Samples from each well were analyzed quarterly by the ANL Environmental Monitoring Laboratory for total alpha, total beta, and hydrogen-3 and were analyzed annually for strontium-90 and radium-226. In addition, uranium concentrations are also determined annually. Though uranium is not listed in the primary drinking water standards, its presence is determined because of use at various sites at ANL in the early years of operation. Since uranium is an alpha-emitting radionuclide, its presence would be detected in 
TABLE 6.1

Safe Drinking Water Standards

(Concentrations are in $\mathrm{mg} / \mathrm{L}$ unless otherwise shown)

\begin{tabular}{|c|c|c|}
\hline Type & Constituent & Limit \\
\hline Metals & $\begin{array}{l}\text { Arsenic } \\
\text { Barium } \\
\text { Cadmium } \\
\text { Chromium } \\
\text { Lead } \\
\text { Mercury } \\
\text { Selenium } \\
\text { Silver }\end{array}$ & $\begin{array}{l}0.05 \\
1.0 \\
0.01 \\
0.05 \\
0.05 \\
0.002 \\
0.01 \\
0.05\end{array}$ \\
\hline Inorganics & $\begin{array}{l}\text { Fluoride } \\
\text { Nitrate } \\
\text { Turbidity } \\
\text { Total Coliforms } \\
\text { Total Dissolved Solids" }\end{array}$ & $\begin{array}{l}1.2-2.4 \\
10 \\
1 \text { NTU } \\
<5 \% \text { positive } \\
500\end{array}$ \\
\hline Pesticides & $\begin{array}{l}\text { Endrin } \\
\text { Lindane } \\
\text { Methoxychlor } \\
\text { Toxaphene }\end{array}$ & $\begin{array}{l}0.002 \\
0.004 \\
0.01 \\
0.005\end{array}$ \\
\hline Herbicides & $\begin{array}{l}2,4-D \\
2,4,5 \text { - TP Silvex }\end{array}$ & $\begin{array}{l}0.1 \\
0.01\end{array}$ \\
\hline Radioactivity & $\begin{array}{l}\text { Gross Alpha } \\
\text { Gross Beta } \\
\text { Hydrogen-3 } \\
\text { Radium }(226+228) \\
\text { Strontium-90 }\end{array}$ & $\begin{array}{l}15 \mathrm{pCi} / \mathrm{L} \\
50 \mathrm{pCi} / \mathrm{L} \\
2 \times 10^{4} \mathrm{pCi} / \mathrm{L} \\
5 \mathrm{pCi} / \mathrm{L} \\
8 \mathrm{pCi/L}\end{array}$ \\
\hline Volatile Organics & $\begin{array}{l}\text { Benzene } \\
\text { Vinyl Chloride } \\
\text { Carbon Tetrachloride } \\
\text { 1,2-Dichloroethane } \\
\text { Trichloroethylene } \\
\text { 1,1-Dichloroethylene } \\
\text { 1,1,1-Trichloroethane } \\
\text { p-Dichlorobenzene }\end{array}$ & $\begin{array}{l}0.005 \\
0.002 \\
0.005 \\
0.005 \\
0.005 \\
0.007 \\
0.200 \\
0.075\end{array}$ \\
\hline
\end{tabular}

"NTU stands for Nephiemetric Turbidity Units.

"This parameter is part of the Secondary Drinking Water Standards. A11 others are Primary Drinking Water Standards. 
the gross alpha measurements and regulated by the gross alpha standard. The finished water sample was analyzed for these same radiological constituents. The results are shown in Table 6.2 for well samples and finished (tap) water samples. The EPA limits for these nuclides are shown in Table 6.1

Results presented in Table 6.2 indicate that the annual average values for all measurements were well within the EPA drinking water standards. We11s \#1 and \#2 had measurable levels of hydrogen-3 at various times during the year, although the average concentration was only about $1 \%$ of the EPA standard. It is speculated that the source of the hydrogen-3 was liquid wastes placed in a holding pond in the sewage treatment area (location 10M in Figure 1.1) in the 1950s. The tritiated water may have migrated through the soil to the dolomite aquifer and was drawn into the wells. Well \#1, which is about $200 \mathrm{~m}(650 \mathrm{ft})$ north of the treatment area, had higher hydrogen-3 concentrations than Well \#2, which is about $300 \mathrm{~m}(1000 \mathrm{ft})$ from the treatment area. Although the normal subsurface water flow gradient is toward the south, the cone of depression created by pumping these wells alters the normal flow pattern. The holding pond has not been used since the early 1960s.

A11 four of the domestic water wells as well as the treated domestic water supply were also analyzed for all drinking water standard constituents. No organic compounds, other than the halomethanes produced by chlorination in the finished water, were detected. The halomethanes were well below the limit of $100 \mu \mathrm{g} / \mathrm{L}$. The levels of metals found were acceptable. Total dissolved solids and turbidity in the domestic water exceeded the IEPA limits of $500 \mathrm{mg} / \mathrm{L}$ and 1 NTU, respectively. Well \#1 has been removed from service due to excessive total dissolved solid levels and other problems.

\subsection{Groundwater Monitoring at Waste Management Sites}

ANL has occupied its current site since 1948. Since that time, waste generated by the Laboratory has been placed in a number of on-site disposal units ranging from ditches filled with construction and demolition debris during the 1950s to a modern sanitary landfill currently used for nonhazardous solid waste disposal. Several of these units are thought to contain 
TABLE 6.2

Radioactivity in ANL Domestic Wells, 1990

(Concentrations in $\mathrm{pC} / \mathrm{L}$ )

\begin{tabular}{|c|c|c|c|c|c|}
\hline $\begin{array}{l}\text { Type of } \\
\text { Activity }\end{array}$ & Location & $\begin{array}{l}\text { No. of } \\
\text { Samples }\end{array}$ & Avg. & Min. & $\operatorname{Max}$ \\
\hline $\begin{array}{l}\text { Alpha } \\
\text { (nonvolatile) }\end{array}$ & $\begin{array}{l}\text { We11 \#1 } \\
\text { We11 } \# 2 \\
\text { We11 } \# 3 \\
\text { We11 \#4 } \\
\text { Tap }\end{array}$ & $\begin{array}{l}3 \\
4 \\
4 \\
4 \\
1\end{array}$ & $\begin{array}{r}12.0 \\
5.3 \\
3.3 \\
2.7 \\
-\end{array}$ & $\begin{array}{l}4.5 \\
5.0 \\
2.1 \\
1.9 \\
-\end{array}$ & $\begin{array}{r}16.5 \\
5.9 \\
5.4 \\
3.5 \\
1.8\end{array}$ \\
\hline $\begin{array}{l}\text { Beta } \\
\text { (nonvolatile) }\end{array}$ & $\begin{array}{l}\text { We11 \#1 } \\
\text { We11 \#2 } \\
\text { We11 \#3 } \\
\text { We11 \#4 } \\
\text { Tap }\end{array}$ & $\begin{array}{l}3 \\
4 \\
4 \\
4 \\
1\end{array}$ & $\begin{array}{r}16.6 \\
9.4 \\
9.2 \\
8.1 \\
-\end{array}$ & $\begin{array}{l}9.6 \\
7.2 \\
7.6 \\
6.6 \\
-\end{array}$ & $\begin{array}{r}27.6 \\
12.1 \\
10.9 \\
10.1 \\
5.0\end{array}$ \\
\hline Hydrogen-3 & $\begin{array}{l}\text { We11 \#1 } \\
\text { We11 \#2 } \\
\text { We11 \#3 } \\
\text { We11 \#4 } \\
\text { Tap }\end{array}$ & $\begin{array}{l}3 \\
4 \\
4 \\
4 \\
1\end{array}$ & $\begin{array}{r}215 \\
154 \\
<100 \\
<100\end{array}$ & $\begin{array}{r}168 \\
<100 \\
<100 \\
<100\end{array}$ & $\begin{array}{r}271 \\
210 \\
<100 \\
<100 \\
<100\end{array}$ \\
\hline Strontium-90 & $\begin{array}{l}\text { We11 \#2 } \\
\text { We11 \#3 } \\
\text { We11 \#4 } \\
\text { Tap }\end{array}$ & $\begin{array}{l}1 \\
1 \\
1 \\
1\end{array}$ & $\begin{array}{l}- \\
- \\
-\end{array}$ & $\begin{array}{l}- \\
- \\
-\end{array}$ & $\begin{array}{l}<0.25 \\
<0.25 \\
<0.25 \\
<0.25\end{array}$ \\
\hline Radium-226 & $\begin{array}{l}\text { We11 \#2 } \\
\text { We11 \#3 } \\
\text { We11 \#4 } \\
\text { Tap }\end{array}$ & $\begin{array}{l}1 \\
1 \\
1 \\
1\end{array}$ & $\begin{array}{l}- \\
- \\
-\end{array}$ & $\begin{array}{l}- \\
- \\
-\end{array}$ & $\begin{array}{l}1.16 \\
0.67 \\
0.89 \\
0.94\end{array}$ \\
\hline $\begin{array}{l}\text { Uranium } \\
\text { (natural) }\end{array}$ & $\begin{array}{l}\text { We11 \#2 } \\
\text { We11 \#3 } \\
\text { We11 \#4 } \\
\text { Tap }\end{array}$ & $\begin{array}{l}1 \\
1 \\
1 \\
1\end{array}$ & $\begin{array}{l}- \\
- \\
-\end{array}$ & $\begin{array}{l}- \\
- \\
-\end{array}$ & $\begin{array}{l}1.54 \\
0.88 \\
0.94 \\
0.61\end{array}$ \\
\hline
\end{tabular}


significant amounts of hazardous materials and therefore represent a potential threat to the environment. Groundwater below these sites is monitored routinely to assess the amount and nature of hazardous chemical releases from these units. The sites which are routinely monitored are the sanitary landfill in the 800 Area and the $317 / 319$ Area, which consists of eight separate waste management units located within a sma11 geographical area. The site of an inactive experimental reactor, $C P-5$, is also monitored periodicaliy to determine if any releases of radionuclides occurred from this unit.

\section{$6.2 .1 .317 / 319$ Area}

Management of waste has been conducted in eight separate units within the 317 and 319 Areas. The 317 Area is currently used as a temporary storage area for radioactive waste before it is shipped off-site for disposal. The area also contains two RCRA permitted units which are scheduled to undergo closure in the near future. The 319 Area is an inactive landfill adjacent to the 317 Area. In addition to these units, a second 1 andfill site, the ENE 1 andfi11, is located to the east-northeast of the 319 Area. This unit was used in the late 1940s and early 1950s for the disposal of primarily construction debris from several sites, including the University of Chicago's Manhattan Project. A sketch of the 317/319 Area is shown in Figure 6.1.

The most significant units in this area in terms of groundwater impact are an inactive French drain (dry we11) in the 317 area and the 1 andfill and French drain in the 319 Area. The 317 Area French drain operated until the mid 1950s and was used for disposal of unknown amounts of liquid chemical wastes. The 1 andfill at 319 was operated from the mid-1950s until 1968 when the sanitary landfill in the 800 Area was put into use. The French drain, similar to the one in the 317 Area, was operated until 1968. Small quantities of a wide variety of liquid wastes, including heavy metals, solvents and waste oil, some containing $\mathrm{PBCS}$, were poured into this drain.

The 317 Area contains six vaults used for temporary storage of solid radioactive waste. Water from footing drains and/or sumps is collected and 


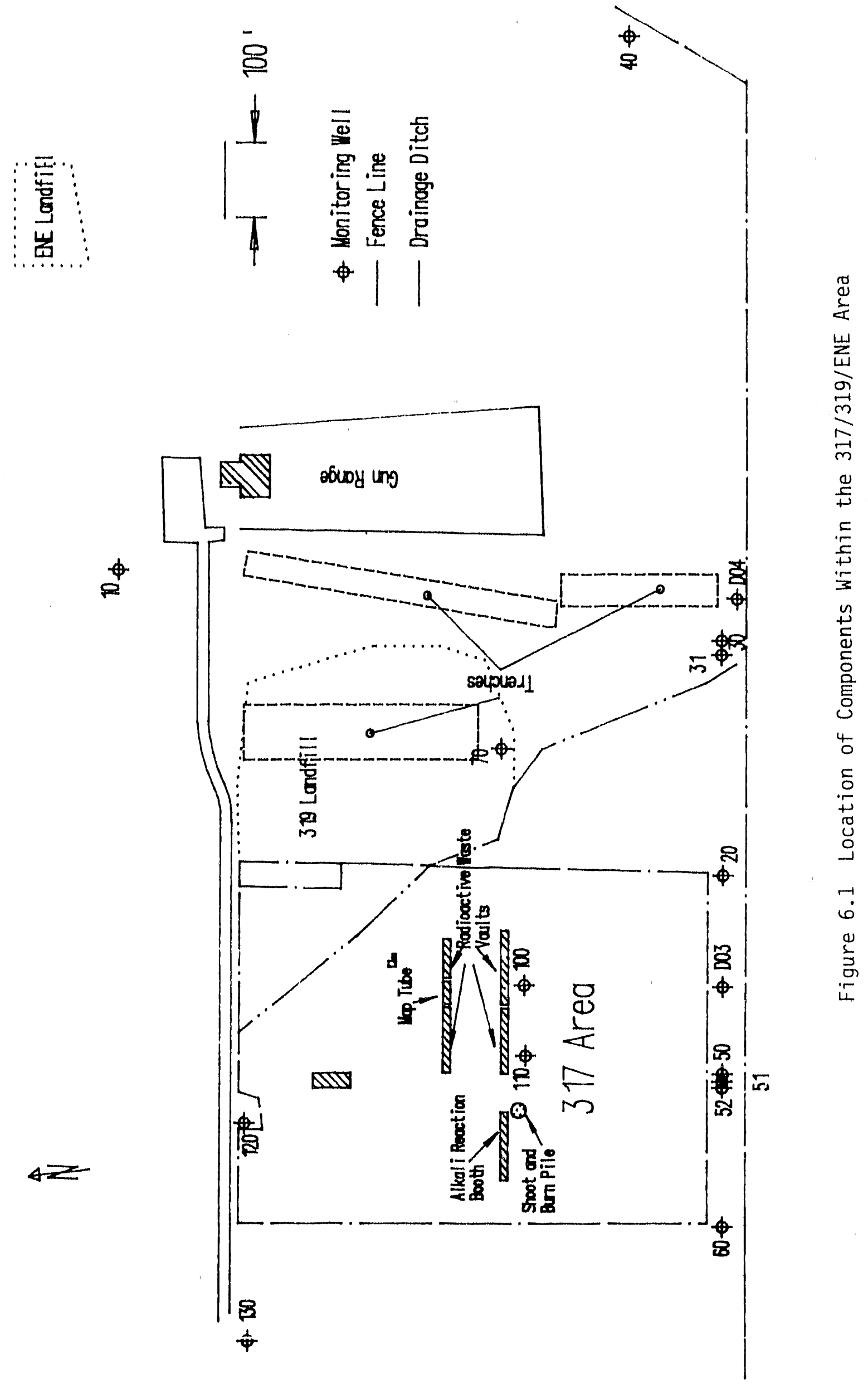


discharged into a sewer system nearby. This sewer system, which was designed to drain off-stte, was permanently closed in 1986 after is was discovered that the water contained very small amounts of several radionuclides. Water collecting in the sewer system is pertodically pumped out into portable tanks, transported to the Waste Management Butlding and analyzed for radioactivity before release to the laboratory sewage collection system. Samples of water are collected monthly from two manholes in the system and these samples are analyzed for volatile organtc compounds. The results of this analysis are discussed later.

The 319 Area currently consists of a mound created by waste fil1 act 1 vities. The waste consisted of noncombustible refuse, demolition and construction debris. In addition, suspect waste (material which was not known to be contaminated but which had the potential for hidden radioactive contamination which could not be confirmed by direct measurement, such as the inside of long pipes or ductwork) was also placed in this unit. The 1 andfill consisted of a number of trenches, 3 to $5 \mathrm{~m}(10$ to $15 \mathrm{ft})$ deep, which were filled with waste material. When the trenches were filled with waste, they were covered with so11. A recent geophysical survey has identified at least three of these trenches.

The French drain in the 319 Area was constructed in the late 1950s in an area of the fill material by placing a corrugated steel pipe vertically into a gravel-fflled excavation and backftlling around the pipe. Waste liquids were poured into the pit and flowed into the pipe.

The ENE landfill is believed to consist primarily of construction debris, and other noncombustible rubbish, such as metal turnings and empty steel drums. The waste was placed in a natural ravine and covered with soil.

6.2.2. Groundwater Monitoring at the $317 / 319$ Area

Groundwater monitoring in the $317 / 319$ Area has been conducted since 1986. The location of the wells is shown in Figure 6.2. Wells 300010 , 300020,300030 , and 300040 were installed in September 1986; 300050 and 

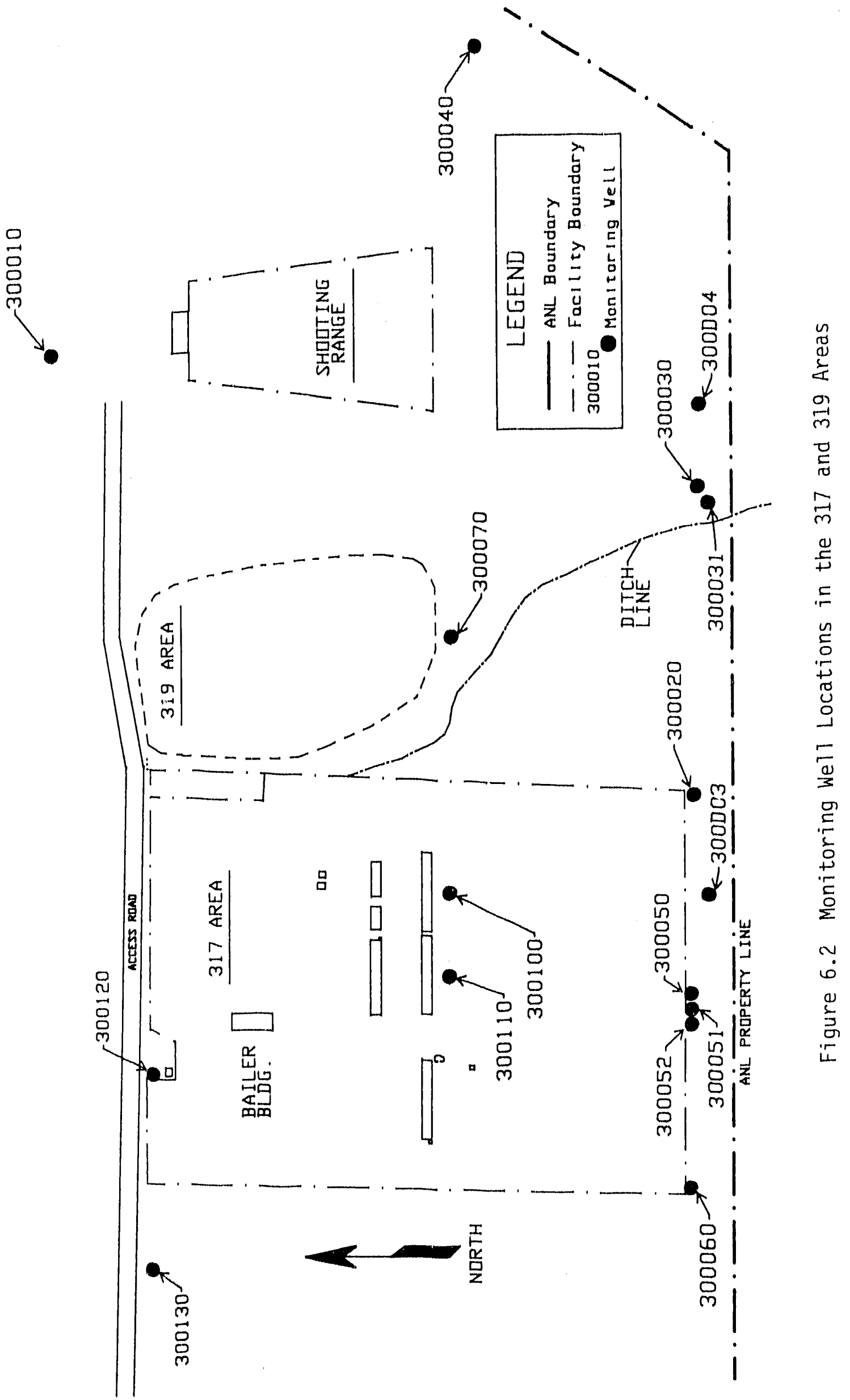
300060 in August 1987; 300070, 300100, and 300110 in July 1988; 300120 and 300130 in September 1988; and wells 300031, 300051, and 300052 were installed in June 1989. These wells were all completed in the glactal till. In addition, wells 300003 and 300004 were tnstalled in November 1989 and reach the dolomite aquffer at about $25 \mathrm{~m}(80 \mathrm{ft})$ below the surface.

We11s 300120 and 300130 are upgradtent of the 317 storage area and we11 300010 is upgradient of the 3191 andf 111 area. A salid lens present at 5-8 II) (15-25 ft) was recently discovered and wel1s 300051, 300052 and 300031 were placed at this depth. Thts layer is also intercepted by wells 300100 , 300110 , and 300120 .

\subsubsection{Sample collection}

The monttoring we11s are sampled using the protocol 1isted in the RCRA Groundwater Monttoring Technical Enforcement Gutdance Document. ${ }^{21}$ The volume of the water in the casing is determined by measuring the water depth from the surface and the depth to the bottom of the well. This latter measurement also determines whether siltation has occurred that might restrict water movement in the screen area. For those wells in the glactal till that do not recharge rapidly, the well is emptied and the volume removed compared to the calculated volume. After approximately 24 hours, the water level is remeasured, and the refill volume is compared to the original volume. In most cases these volumes are nearly identical. The well is then sampled by balling with a Teflon batler. The field parameters for these samples ( $\mathrm{pH}$, specific conductance, redox potential and temperature) are measured statically. For those samples in the porous, saturated zone which recharge rapidly, three well volumes are purged while the field parameters are measured continuously. These parameters stabilize quickly in these wells. In the case of the dolomite wells, samples are collected as soon as these readings stabilize. Samples for volatile organtcs, semivolatile organics, PCB/pesticides, metals, and radioactivity are collected in that order. The samples are placed in precleaned bottles, labelled and preserved. 
During each sampling event, one well is selected for replicate sampling. An effort is made to vary this selection so that replicates are obtained at every well over the course of time.

\subsubsection{Sample Analysis}

Metal analyses were performed using methods 1 isted in the Statement of Work for Inorganic Analysis No. 787 or No. 788 of the EPA Contract Laboratory Program. The volatile organic analyses were performed using capillary coluirin methods in SW-846. Analyses for semivolatile and PCB/pesticides were performed using the Organic Statement of Work No. 2188 of the EPA Contract Laboratory Program. All samples were analyzed within the required holding times or this deficiency was noted. In the case of volattle organic analysis, an effort was made to identify compounds which are present, but are not included on the method 1ist. In many cases, this was successfully accomplished and standard solutions of these compounds were prepared and analyzed.

\subsubsection{Results of Analyses}

The description of each we11, a listing of field parameters measured during sample collection, and the results of chemical and radiological analyses of samples from the wells in the $317 / 319$ Area are contained in Tables 6.4 through 6.15. All radiological and inorganic analyses results are shown in these tables. The analysis methods used for organic compounds will identify and quantify all the compounds contained in the CLP Target Compound List shown in Table 6.3. However, the vast majority of these compounds were not detected in the samples. To simplify the format of these tables, these negative results are not included. Only those constituents which were present in amounts great enough to quantify are shown. The detection 1 imits for the organic compounds 1isted were typically 5 to 10 $\mu \mathrm{g} / \mathrm{L}$. 
TABLE 6.3

Target Compound List

Volatile

Chloromethane

Bromomethane

Vinyl Chloride

Chloroethane

Methylene Chloride

Acetone

Carbon Disulfide

1,1-Dichloroethene

cis-1,2-Dichloroethene

1,1-Dichloroethane

Chloroform

1,2-Dichloroethane

2-Butanone

1,1,1-Trichloroe thane

Carbon Tetrachloride

Vinyl Acetate

Bromodichloromethane

Semi-Volatile

Phenol

bis (2-Chioroethyl)ether

2-Chlorophenol

1,3-Dichlorobenzene

1,4-Dichlorobenzene

Benzyl Alcohol

1,2-Dichlorobenzene

2-Methylphenol

bis (2-ChToroisopropyl)ether

4-Methylphenol

$\mathrm{N}-\mathrm{Nit}$ toso-Di-n-proplyamine

Hexachloroethane

Nitrobenzene

Isophorone

2-Nitrophenol

2,4-Dimethylphenol

Benzoic Acid

bis (2-Chloroethoxy) me thane

2,4-Dichlorophenol

1,2,4-Trichlorobenzene

Naphthalerie

4-Chloroaniline
1,2-Dichloropropane

cis-1,3-Dichloropropene

Trich Toroethene

Dibromochloromethane

1,1,2-Trichloroethane

Benzene

trans-1,3-Dichloropropene

Bromoform

4-Methy1-2-Pentanone

2-Hexanone

Tetrachloroethene

$1,1,2,2$-Tetrachloroethane

Toluene

Chlorobenzene

Ethylbenzene

Styrene

Xylene (total)
2,4,6-Trichlorophenol

2,4,5-Trichlorophenol

2-Chloronaphthalene

2-Nitroaniline

Dimethylphthalate

Acenaphithylene

2,6-Dinitrotolune

3-Nitroaniline

Acenapthene

4-Nitrophenol

Dibenzofuran

2,4-Dinotrotoluene

Diethylphthalate

4-Chlorophenyl-phenylether

Fluorene

4-Nitroaniline

4,6-Dinitro-2-methylphenol

$\mathrm{N}-\mathrm{Ni}$ trosodiphenyl amine

4-Bromophenyl-phenylether

Hexachlorobenzene

Pentachlorophenol

Phenanthrene 
TABLE 6.3 (Contd.)

Hexachlorobutadiene

4-Chloro-3-methylphenol

2-Methylnaphthalene

Hexachlorocyclopentadiene

Butylbenzylphthalate

3, 3'-Dichlorobenzidine

Benzo $(\alpha)$ anthracene

Chrysene

bis (2-Ethylhexyl)phthalate

Di-n-0ctylphthalate
Anthracene

Di-n-Butylphthalate

Fluoranthene

Pyrene

Benzo (b) fluoranthene

Benzo (k)fluoranthene

Benzo $(\alpha)$ pyrene

Indeno (1,2,3-cd)pyrene

Dibenzo $(a, h)$ anthracene

Benzo( $g, h, i)$ perylene

\section{Pesticides and Herbicides}

Alpha BHC

Beta $B H C$

Delta $B H C$

Lindane

Methoxychior

Heptachlor

Heptachlor Epoxide

Aldrin

4,4, DDD

$4,4^{\prime}$ DDE
4, 4' DDT

Dieldrin

Endrin

Endrin Ketone

Endosulfan I

Endosulfan II

Endosulfan Sulfate

Alpha Chlodane

Gamma Chlordane

Toxaphene

$\underline{\text { PCBS }}$

Aroclor 1016

Aroclor 1221

Aroclor 1232

Aroclor 1242
Aroclor 1248

Aroclor 1254

Aroclor 1260 
TABLE 6.4

Groundwater Monitoring Results, 300 Area Well \#300010, 1990

\begin{tabular}{|c|c|c|c|c|}
\hline & & $\begin{array}{l}\text { Well Point } \\
\text { Ground Surf } \\
\text { Casing Mate }\end{array}$ & $\begin{array}{l}\text { evation } \\
\text { e Elevation } \\
\text { al: }\end{array}$ & $\begin{array}{l}m(M S L) \\
196.950 \\
209.81 \\
\text { PVC }\end{array}$ \\
\hline Constituent & Units & $06 / 05 / 90$ & $08 / 29 / 90$ & $11 / 16 / 90$ \\
\hline $\begin{array}{l}\text { Water Elevation } \\
\text { Temperature } \\
\text { pH } \\
\text { Redox } \\
\text { Conductivity }\end{array}$ & $\begin{array}{l}{ }^{\mathrm{m}} \\
{ }^{\circ} \mathrm{C} \\
\mathrm{pH} \\
\mathrm{mV} \\
\mu \mathrm{mhos} / \mathrm{cm}\end{array}$ & $\begin{array}{l}200.06 \\
10.5 \\
6.44 \\
80 \\
785\end{array}$ & $\begin{array}{l}199.05 \\
12.3 \\
6.85 \\
71 \\
-\end{array}$ & $\begin{array}{l}198.38 \\
11.4 \\
6.77 \\
-14 \\
816\end{array}$ \\
\hline $\begin{array}{l}\text { Arsenic } \\
\text { Barium } \\
\text { Beryllium } \\
\text { Cadmium } \\
\text { Chloride } \\
\text { Chromium } \\
\text { Cobalt } \\
\text { Copper } \\
\text { Iron } \\
\text { Lead } \\
\text { Manganese } \\
\text { Mercury } \\
\text { Nickel } \\
\text { Silver } \\
\text { Thallium } \\
\text { Vanadium } \\
\text { Zinc } \\
\text { Cesium-137 } \\
\text { Hydrogen-3 } \\
\text { Strontium-90 }\end{array}$ & $\begin{array}{l}\mathrm{mg} / \mathrm{L} \\
\mathrm{mg} / \mathrm{L} \\
\mu \mathrm{g} / \mathrm{L} \\
\mathrm{mg} / \mathrm{L} \\
\mathrm{mg} / \mathrm{L} \\
\mathrm{mg} / \mathrm{L} \\
\mathrm{mg} / \mathrm{L} \\
\mathrm{mg} / \mathrm{L} \\
\mathrm{mg} / \mathrm{L} \\
\mathrm{mg} / \mathrm{L} \\
\mathrm{mg} / \mathrm{L} \\
\mu \mathrm{g} / \mathrm{L} \\
\mathrm{mg} / \mathrm{L} \\
\mathrm{mg} / \mathrm{L} \\
\mathrm{mg} / \mathrm{L} \\
\mathrm{mg} / \mathrm{L} \\
\mathrm{mg} / \mathrm{L} \\
\mathrm{pCi} / \mathrm{L} \\
\mathrm{nCi} / \mathrm{L} \\
\mathrm{pCi} / \mathrm{L}\end{array}$ & $\begin{aligned}< & 0.0025 \\
& 0.0400 \\
< & 0.2 \\
& 0.0004 \\
& 26 \\
< & 0.004 \\
< & 0.03 \\
& 0.01 \\
& 0.2 \\
& 0.005 \\
& 0.240 \\
< & 0.1 \\
< & 0.025 \\
< & 0.0005 \\
< & 0.01 \\
< & 0.015 \\
& 0.02 \\
< & 1 \\
& 0.122 \\
< & 0.25\end{aligned}$ & $\begin{aligned}< & 0.0025 \\
& 0.0447 \\
< & 0.2 \\
< & 0.0003 \\
& 21 \\
< & 0.004 \\
< & 0.03 \\
< & 0.01 \\
& 0.3 \\
< & 0.002 \\
& 0.128 \\
< & 0.1 \\
& 0.048 \\
< & 0.0005 \\
< & 0.01 \\
< & 0.015 \\
& 0.02 \\
< & 1 \\
& 0.229 \\
< & 0.25\end{aligned}$ & $\begin{aligned}< & 0.0025 \\
& 0.0320 \\
< & 5.0 \\
< & 0.0050 \\
& 25 \\
& 0.012 \\
< & 0.05 \\
< & 0.01 \\
& 2.6 \\
& 0.005 \\
& 0.610 \\
< & 0.1 \\
< & 0.040 \\
< & 0.0100 \\
< & 0.01 \\
& 0.059 \\
& 0.02 \\
< & 1 \\
& 0.117 \\
< & 0.25\end{aligned}$ \\
\hline
\end{tabular}


TABLE 6.5

Groundwater Monitoring Results, 300 Area Well \#300020, 1990

$\begin{array}{ll}\text { Wel1 Point Elevation } & \mathrm{m} \text { (MSL) } \\ \text { Ground Surface Elevation } & 209.90 \\ \text { Casing Material: } & \text { PVC }\end{array}$

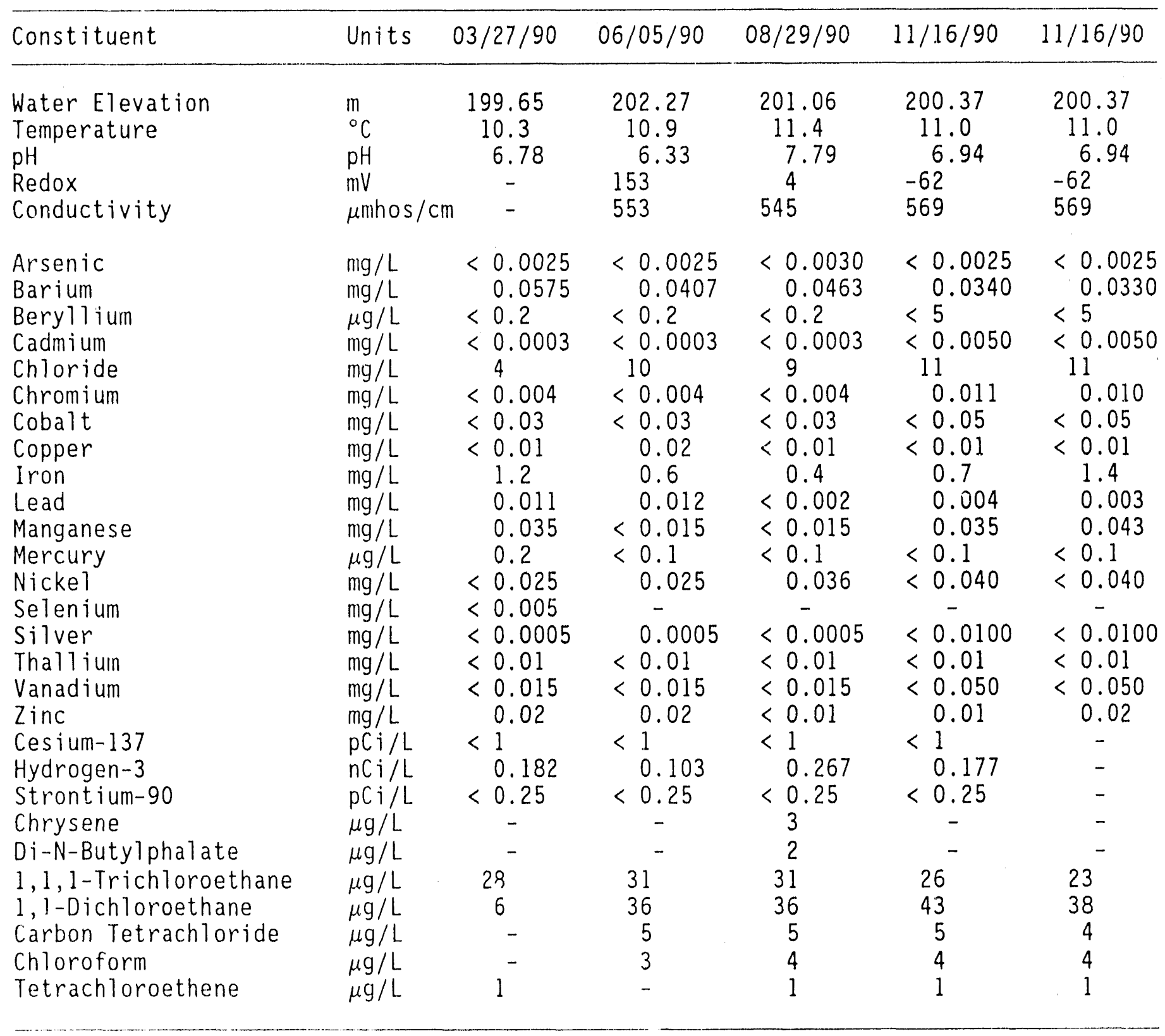


TABLE 6.6

Groundwater Monitoring Results, 300 Area We11 \#300030, 1990

\begin{tabular}{|c|c|c|c|c|}
\hline & & $\begin{array}{l}\text { We11 Point } \\
\text { Ground Surf } \\
\text { Casing Mate }\end{array}$ & $\begin{array}{l}\text { evation } \\
\text { e Elevation } \\
\text { al: }\end{array}$ & $\begin{array}{l}m(M S L) \\
192.08 \\
204.28 \\
\text { PVC }\end{array}$ \\
\hline Constituent & Units & $06 / 05 / 90$ & $08 / 30 / 90$ & $11 / 15 / 90$ \\
\hline Water Elevation & $m$ & 193.15 & 193.11 & 193.11 \\
\hline Temperature & ${ }^{\circ} \mathrm{C}$ & - & - & 10.50 \\
\hline $\mathrm{pH}$ & $\mathrm{pH}$ & - & - & 6.99 \\
\hline Redox & $\mathrm{mV}$ & - & - & -74 \\
\hline Conductivity & $\mu \mathrm{mhos} / \mathrm{cm}$ & - & - & 705 \\
\hline Arsenic & $\mathrm{mg} / \mathrm{L}$ & 0.0029 & $<0.0025$ & 0.0030 \\
\hline Barium & $\mathrm{mg} / \mathrm{L}$ & 0.0862 & 0.0611 & 0.2310 \\
\hline Beryllium & $\mu \mathrm{g} / \mathrm{L}$ & $<0.2$ & $<0.2$ & 11.0 \\
\hline Cadmium & $\mathrm{mg} / \mathrm{L}$ & 0.0003 & 0.0003 & 0.0090 \\
\hline Chloride & $\mathrm{mg} / \mathrm{L}$ & 31 & 33 & \\
\hline Chromium & $\mathrm{mg} / \mathrm{L}$ & 0.006 & 0.004 & 0.120 \\
\hline Cobalt & $\mathrm{mg} / \mathrm{L}$ & 0.03 & $<0.03$ & $<0.05$ \\
\hline Copper & $\mathrm{mg} / \mathrm{L}$ & 0.02 & 0.02 & 0.07 \\
\hline Iron & $\mathrm{mg} / \mathrm{L}$ & 8.4 & 4.0 & 110.0 \\
\hline Lead & $\mathrm{mg} / \mathrm{L}$ & 0.012 & 0.015 & 0.053 \\
\hline Manganese & $\mathrm{mg} / \mathrm{L}$ & 0.136 & 0.119 & 2.450 \\
\hline Mercury & $\mu \mathrm{g} / \mathrm{L}$ & $<0.1$ & $<0.1$ & $<0.1$ \\
\hline Nickel & $\mathrm{mg} / \mathrm{L}$ & $<0.025$ & 0.072 & $<0.110$ \\
\hline Silver & $\mathrm{mg} / \mathrm{L}$ & $<0.0005$ & $<0.0005$ & $<0.0100$ \\
\hline Thallium & $\mathrm{mg} / \mathrm{L}$ & $<0.01$ & $<0.01$ & $<0.01$ \\
\hline Vanadium & $\mathrm{mg} / \mathrm{L}$ & $<0.015$ & $<0.015$ & 0.050 \\
\hline Zinc & $\mathrm{mg} / \mathrm{L}$ & 0.06 & 0.03 & 0.04 \\
\hline Cesium- 137 & $p C i / L$ & $<1$ & $<1$ & $<1$ \\
\hline Hydrogen-3 & $\mathrm{nCi} / \mathrm{L}$ & 1.300 & 1.400 & 1.400 \\
\hline strontium-90 & $\mathrm{pCi} / \mathrm{L}$ & $<0.25$ & $<0.25$ & - \\
\hline $1,1,1$-Trich 1 oroethane & $\mu \mathrm{g} / \mathrm{L}$ & - & 5 & 4 \\
\hline 1,1-Dichloroethane & $\mu \mathrm{g} / \mathrm{L}$ & - & 1 & - \\
\hline Chioroform & $\mu \mathrm{g} / \mathrm{L}$ & - & 1 & 1 \\
\hline Trichloroethene & $\mu \mathrm{g} / \mathrm{L}$ & 6 & 5 & 5 \\
\hline
\end{tabular}


TABLE 6.7

Groundwater Monitoring Results, 300 Area We11 \#300031, 1990

\begin{tabular}{|c|c|c|c|c|c|}
\hline \multirow[b]{2}{*}{ Constituent } & \multirow[b]{2}{*}{ Units } & \multirow[b]{2}{*}{$03 / 26 / 90$} & \multicolumn{2}{|c|}{$\begin{array}{l}\text { Je } 11 \text { Point Elevation } \\
\text { around Surface Elevation } \\
\text { asing Material: }\end{array}$} & \multirow{2}{*}{$\begin{array}{l}m(M S L) \\
195.82 \\
204.28 \\
\text { PVC } \\
11 / 15 / 90\end{array}$} \\
\hline & & & $06 / 04 / 90$ & $08 / 29 / 90$ & \\
\hline $\begin{array}{l}\text { Water Elevation } \\
\text { Temperature } \\
\text { pH } \\
\text { Redox } \\
\text { Conductivity }\end{array}$ & $\begin{array}{l}{ }_{{ }^{\circ} \mathrm{C}}^{\mathrm{C}} \\
\mathrm{pH} \\
\mathrm{mV} \\
\mu \mathrm{mhos} / \mathrm{cm}\end{array}$ & $\begin{array}{c}197.54 \\
10.0 \\
6.84 \\
- \\
1044\end{array}$ & $\begin{array}{l}197.82 \\
10.4 \\
6.64 \\
144 \\
789\end{array}$ & $\begin{array}{l}197.46 \\
13.2 \\
7.75 \\
29 \\
800\end{array}$ & $\begin{array}{l}197.54 \\
11.0 \\
6.88 \\
-80 \\
802\end{array}$ \\
\hline $\begin{array}{l}\text { Arsenic } \\
\text { Barium } \\
\text { Beryllium } \\
\text { Cadmium } \\
\text { Chloride } \\
\text { Chromium } \\
\text { Cobalt } \\
\text { Copper } \\
\text { Iron } \\
\text { Lead } \\
\text { Manganese } \\
\text { Mercury } \\
\text { Nickel } \\
\text { Selenium } \\
\text { Silver } \\
\text { Thallium } \\
\text { Vanadium } \\
\text { Zinc } \\
\text { Cesium-137 } \\
\text { Hydrogen-3 } \\
\text { Strontium-90 }\end{array}$ & $\begin{array}{l}\mathrm{mg} / \mathrm{L} \\
\mathrm{mg} / \mathrm{L} \\
\mu \mathrm{g} / \mathrm{L} \\
\mathrm{mg} / \mathrm{L} \\
\mathrm{mg} / \mathrm{L} \\
\mathrm{mg} / \mathrm{L} \\
\mathrm{mg} / \mathrm{L} \\
\mathrm{mg} / \mathrm{L} \\
\mathrm{mg} / \mathrm{L} \\
\mathrm{mg} / \mathrm{L} \\
\mathrm{mg} / \mathrm{L} \\
\mu \mathrm{g} / \mathrm{L} \\
\mathrm{mg} / \mathrm{L} \\
\mathrm{mg} / \mathrm{L} \\
\mathrm{mg} / \mathrm{L} \\
\mathrm{mg} / \mathrm{L} \\
\mathrm{mg} / \mathrm{L} \\
\mathrm{mg} / \mathrm{L} \\
\mathrm{pCi} / \mathrm{L} \\
\mathrm{nCi} / \mathrm{L} \\
\mathrm{pCi} / \mathrm{L}\end{array}$ & $\begin{aligned} & 0.0026 \\
& 0.3164 \\
& 0.3 \\
< & 0.0003 \\
& 38 \\
& 0.005 \\
< & 0.03 \\
< & 0.01 \\
& 9.1 \\
& 0.020 \\
& 0.256 \\
< & 0.1 \\
< & 0.025 \\
< & 0.005 \\
< & 0.0005 \\
< & 0.01 \\
< & 0.015 \\
& 0.03 \\
< & 1.700 \\
& 1.700 \\
< & 0.25\end{aligned}$ & $\begin{aligned} & 0.0055 \\
& 0.2722 \\
& 1.2 \\
& 0.0005 \\
46 & \\
& 0.015 \\
< & 0.03 \\
& 0.04 \\
& 27.4 \\
& 0.031 \\
& 0.564 \\
< & 0.1 \\
< & 0.025 \\
& - \\
< & 0.0005 \\
< & 0.01 \\
& 0.019 \\
& 0.10 \\
< & 1 \\
& 1.200 \\
< & 0.25\end{aligned}$ & $\begin{aligned} & 0.0070 \\
& 0.1754 \\
& 0.8 \\
& 0.0005 \\
& 36 \\
& 0.014 \\
& 0.05 \\
& 0.03 \\
& 24.4 \\
& 0.018 \\
& 0.528 \\
&<0.1 \\
& 0.077 \\
& \quad- \\
&<0.0005 \\
&<0.01 \\
& 0.015 \\
& 0.08 \\
&<1 \\
& 1.200 \\
&<0.25\end{aligned}$ & $\begin{aligned} & 0.0048 \\
& 0.2500 \\
< & 5.0 \\
< & 0.0050 \\
& 29 \\
& 0.034 \\
< & 0.05 \\
& 0.02 \\
& 31.0 \\
& 0.027 \\
& 0.715 \\
< & 0.1 \\
< & 0.040 \\
< & 0.0100 \\
< & 0.01 \\
& 0.072 \\
& 0.10 \\
< & 1 \\
& 1.100 \\
< & 0.25\end{aligned}$ \\
\hline
\end{tabular}


TABLE 6.8

Groundwater Monitoring Results, 300 Area We1l \#300052, 1990

\begin{tabular}{|c|c|c|c|c|c|c|}
\hline : & & & $\begin{array}{l}\text { We } 11 \\
\text { Groun } \\
\text { Casin }\end{array}$ & $\begin{array}{l}\text { int Elev } \\
\text { Surface } \\
\text { Material }\end{array}$ & $\begin{array}{l}\text { ion } \\
\text { levation }\end{array}$ & $\begin{array}{l}m(M S L) \\
203.70 \\
208.32 \\
P V C\end{array}$ \\
\hline nstituent & Units & $03 / 27 / 90$ & $06 / 04 / 90$ & $08 / 28 / 90$ & $08 / 29 / 90$ & $11 / 15 / 90$ \\
\hline $\begin{array}{l}\text { Water Elevation } \\
\text { Temperature } \\
\text { pH } \\
\text { Redox } \\
\text { Conductivity }\end{array}$ & $\begin{array}{l}{ }^{\mathrm{m}} \\
{ }^{\circ} \mathrm{C} \\
\mathrm{pH} \\
\mathrm{mV} \\
\mu \mathrm{mhos} / \mathrm{cm}\end{array}$ & $\begin{array}{c}206.26 \\
8.0 \\
7.24 \\
- \\
404^{-}\end{array}$ & $\begin{array}{c}205.45 \\
10.0 \\
7.72 \\
116 \\
473\end{array}$ & $\begin{array}{l}204.82 \\
16.5 \\
7.63 \\
-75 \\
569\end{array}$ & $\begin{array}{c}204.80 \\
17.5 \\
7.15 \\
30 \\
568\end{array}$ & $\begin{array}{c}205.38 \\
13.3 \\
7.17 \\
-50 \\
540\end{array}$ \\
\hline $\begin{array}{l}\text { Arsenic } \\
\text { Barium } \\
\text { Beryllium } \\
\text { Cadmium } \\
\text { Chloride } \\
\text { Chromium } \\
\text { Cobalt } \\
\text { Copper } \\
\text { Iron } \\
\text { Lead } \\
\text { Manganese } \\
\text { Mercury } \\
\text { Nickel } \\
\text { Selenium } \\
\text { Silver } \\
\text { Thallium } \\
\text { Variadium } \\
\text { Zinc } \\
\text { Aroclor-1254 } \\
\text { Cesium-137 } \\
\text { Hydrogen-3 } \\
\text { Strontium-90 } \\
\text { Chrysene } \\
\text { Di-N-Butylphalate }\end{array}$ & $\begin{array}{l}\mathrm{mg} / \mathrm{L} \\
\mathrm{mg} / \mathrm{L} \\
\mu \mathrm{g} / \mathrm{L} \\
\mathrm{mg} / \mathrm{L} \\
\mathrm{mg} / \mathrm{L} \\
\mathrm{mg} / \mathrm{L} \\
\mathrm{mg} / \mathrm{L} \\
\mathrm{mg} / \mathrm{L} \\
\mathrm{mg} / \mathrm{L} \\
\mathrm{mg} / \mathrm{L} \\
\mathrm{mg} / \mathrm{L} \\
\mu \mathrm{g} / \mathrm{L} \\
\mathrm{mg} / \mathrm{L} \\
\mathrm{mg} / \mathrm{L} \\
\mathrm{mg} / \mathrm{L} \\
\mathrm{mg} / \mathrm{L} \\
\mathrm{mg} / \mathrm{L} \\
\mathrm{mg} / \mathrm{L} \\
\mu \mathrm{g} / \mathrm{L} \\
\mathrm{pC} \mathrm{i} / \mathrm{L} \\
\mathrm{nCi} / \mathrm{L} \\
\mathrm{pCi} / \mathrm{L} \\
\mu \mathrm{g} / \mathrm{L} \\
\mu \mathrm{g} / \mathrm{L}\end{array}$ & $\begin{aligned} & 0.0025 \\
& 0.3474 \\
& 2.2 \\
& 0.0056 \\
& 3 \\
& 0.067 \\
& 0.07 \\
& 0.16 \\
& 233.0 \\
& 0.051 \\
& 1.884 \\
&<0.1 \\
& 0.144 \\
&<0.005 \\
&<0.0005 \\
&<0.01 \\
& 0.040 \\
& 0.58 \\
&- \\
&<1 \\
& 0.289 \\
& \quad- \\
&- \\
&-\end{aligned}$ & $\begin{array}{rl} & 0.0025 \\
0.1336 & 1.2 \\
1.2 & 0.0015 \\
2 \\
0.021 \\
<0.03 \\
0.05 \\
63.4 \\
0.035 \\
0.576 \\
<0.1 \\
0.047 \\
- \\
0.0005 \\
<0.01 \\
0.024 \\
0.19 \\
\quad- \\
<1 \\
<0.100 \\
<0.25 \\
\quad- \\
\quad-\end{array}$ & $\begin{aligned} & 0.0040 \\
& 0.1632 \\
& 1.1 \\
& 0.0020 \\
& 2 \\
& 0.028 \\
& 0.06 \\
& 0.07 \\
& 90.9 \\
& 0.032 \\
& 1.044 \\
&<0.1 \\
& 0.141 \\
&<0.0005 \\
&<0.01 \\
& 0.026 \\
& 0.25 \\
& \quad- \\
&<1 \\
&<0.100 \\
&<0.25 \\
& \quad- \\
&-\end{aligned}$ & 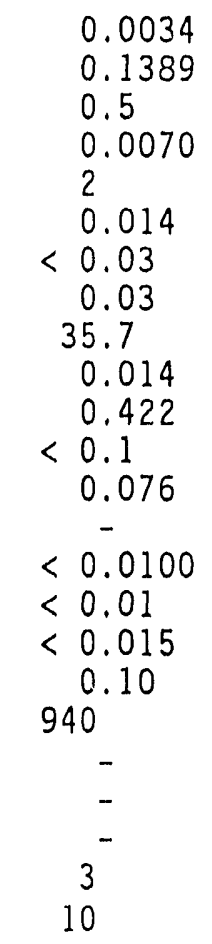 & $\begin{aligned}< & 0.0025 \\
& 0.0410 \\
< & 5.0 \\
< & 0.0050 \\
& 1 \\
& 0.015 \\
< & 0.05 \\
< & 0.01 \\
& 10.3 \\
& 0.006 \\
& 0.112 \\
< & 0.1 \\
< & 0.040 \\
< & - \\
< & 0.0100 \\
< & 0.01 \\
& 0.060 \\
& 0.03 \\
& - \\
< & 1 \\
< & 0.100 \\
< & 0.25 \\
& - \\
& -\end{aligned}$ \\
\hline
\end{tabular}


TABLE 6.9

Groundwater Monitoring Results, 300 Area We11 \#300060, 1990

\begin{tabular}{|c|c|c|c|c|c|}
\hline \multirow[b]{2}{*}{ Constituent } & \multirow[b]{2}{*}{ Units } & \multicolumn{3}{|c|}{$\begin{array}{l}\text { We11 Point Elevation } \\
\text { Ground Surface Elevation } \\
\text { Casing Material: }\end{array}$} & \multirow{2}{*}{$\begin{array}{l}m(M S L) \\
194.93 \\
207.54 \\
\text { PVC } \\
11 / 16 / 90\end{array}$} \\
\hline & & $03 / 27 / 90$ & $06 / 05 / 90$ & $08 / 29 / 90$ & \\
\hline $\begin{array}{l}\text { Water Elevation } \\
\text { Temperature } \\
\text { pH } \\
\text { Redox } \\
\text { Conductivity }\end{array}$ & $\begin{array}{l}\mathrm{m}^{\mathrm{m}} \\
{ }^{\circ} \mathrm{C} \\
\mathrm{pH} \\
\mathrm{mV} \\
\mu \mathrm{mhos} / \mathrm{cm}\end{array}$ & $\begin{array}{c}199.51 \\
10.6 \\
7.25 \\
- \\
-\end{array}$ & $\begin{array}{l}200.97 \\
10.2 \\
6.46 \\
135 \\
762\end{array}$ & $\begin{array}{c}199.53 \\
11.4 \\
6.98 \\
36 \\
773\end{array}$ & $\begin{array}{l}198.91 \\
11.3 \\
7.07 \\
-46 \\
679\end{array}$ \\
\hline $\begin{array}{l}\text { Arsenic } \\
\text { Barium } \\
\text { Beryllium } \\
\text { Cadmium } \\
\text { Chloride } \\
\text { Chromium } \\
\text { Cobalt } \\
\text { Copper } \\
\text { Iron } \\
\text { Lead } \\
\text { Manganese } \\
\text { Mercury } \\
\text { Nicke1 } \\
\text { Selenium } \\
\text { Silver } \\
\text { Thallium } \\
\text { Vanadium } \\
\text { Zinc } \\
\text { Cesium-137 } \\
\text { Hydrogen-3 } \\
\text { Strontium-90 } \\
\text { Chrysene } \\
\text { Di-N-Butylphthalate }\end{array}$ & $\begin{array}{l}\mathrm{mg} / \mathrm{L} \\
\mathrm{mg} / \mathrm{L} \\
\mu \mathrm{g} / \mathrm{L} \\
\mathrm{mg} / \mathrm{L} \\
\mathrm{mg} / \mathrm{L} \\
\mathrm{mg} / \mathrm{L} \\
\mathrm{mg} / \mathrm{L} \\
\mathrm{mg} / \mathrm{L} \\
\mathrm{mg} / \mathrm{L} \\
\mathrm{mg} / \mathrm{L} \\
\mathrm{mg} / \mathrm{L} \\
\mu \mathrm{g} / \mathrm{L} \\
\mathrm{mg} / \mathrm{L} \\
\mathrm{mg} / \mathrm{L} \\
\mathrm{mg} / \mathrm{L} \\
\mathrm{mg} / \mathrm{L} \\
\mathrm{mg} / L \\
\mathrm{mg} / \mathrm{L} \\
\mathrm{pC} \mathrm{i} / \mathrm{L} \\
\mathrm{nC} \mathrm{i} / \mathrm{L} \\
\mathrm{pCi} \mathrm{L} / \mathrm{L} \\
\mu \mathrm{g} / \mathrm{L} \\
\mu \mathrm{g} / \mathrm{L}\end{array}$ & $\begin{array}{rl}< & 0.0025 \\
& 0.0940 \\
< & 0.2 \\
& 0.0006 \\
52 & 52 \\
< & 0.004 \\
< & 0.03 \\
< & 0.01 \\
& 0.4 \\
& 0.015 \\
& 0.046 \\
< & 0.1 \\
< & 0.025 \\
< & 0.005 \\
< & 0.0005 \\
< & 0.01 \\
< & 0.015 \\
< & 0.01 \\
< & 1 \\
& 0.234 \\
< & 0.25 \\
& - \\
& -\end{array}$ & $\begin{aligned}< & 0.0025 \\
& 0.0623 \\
< & 0.2 \\
& 0.0006 \\
& 58 \\
< & 0.004 \\
< & 0.03 \\
& 0.01 \\
& 0.4 \\
& 0.005 \\
& 0.021 \\
< & 0.1 \\
< & 0.025 \\
< & - \\
< & 0.0005 \\
< & 0.01 \\
< & 0.015 \\
& 0.02 \\
< & 1 \\
& 0.277 \\
< & 0.25 \\
& - \\
& -\end{aligned}$ & $\begin{aligned} & 0.0025 \\
& 0.0721 \\
< & 0.2 \\
& 0.0012 \\
& 57 \\
< & 0.004 \\
< & 0.03 \\
< & 0.01 \\
& 0.8 \\
& 0.003 \\
& 0.033 \\
< & 0.1 \\
& 0.048 \\
< & - \\
< & 0.0005 \\
< & 0.01 \\
< & 0.015 \\
& 0.01 \\
< & 1 \\
& 0.228 \\
< & 0.25 \\
& 4 \\
& 7\end{aligned}$ & $\begin{array}{rl}< & 0.0025 \\
& 0.0500 \\
< & 5.0 \\
< & 0.0050 \\
57 & 57 \\
< & 0.010 \\
< & 0.05 \\
< & 0.01 \\
& 0.4 \\
< & 0.002 \\
& 0.054 \\
< & 0.1 \\
< & 0.040 \\
< & - \\
< & 0.0100 \\
< & 0.01 \\
& 0.060 \\
& 0.01 \\
< & 1 \\
& 0.201 \\
< & 0.25 \\
& - \\
- & -\end{array}$ \\
\hline
\end{tabular}




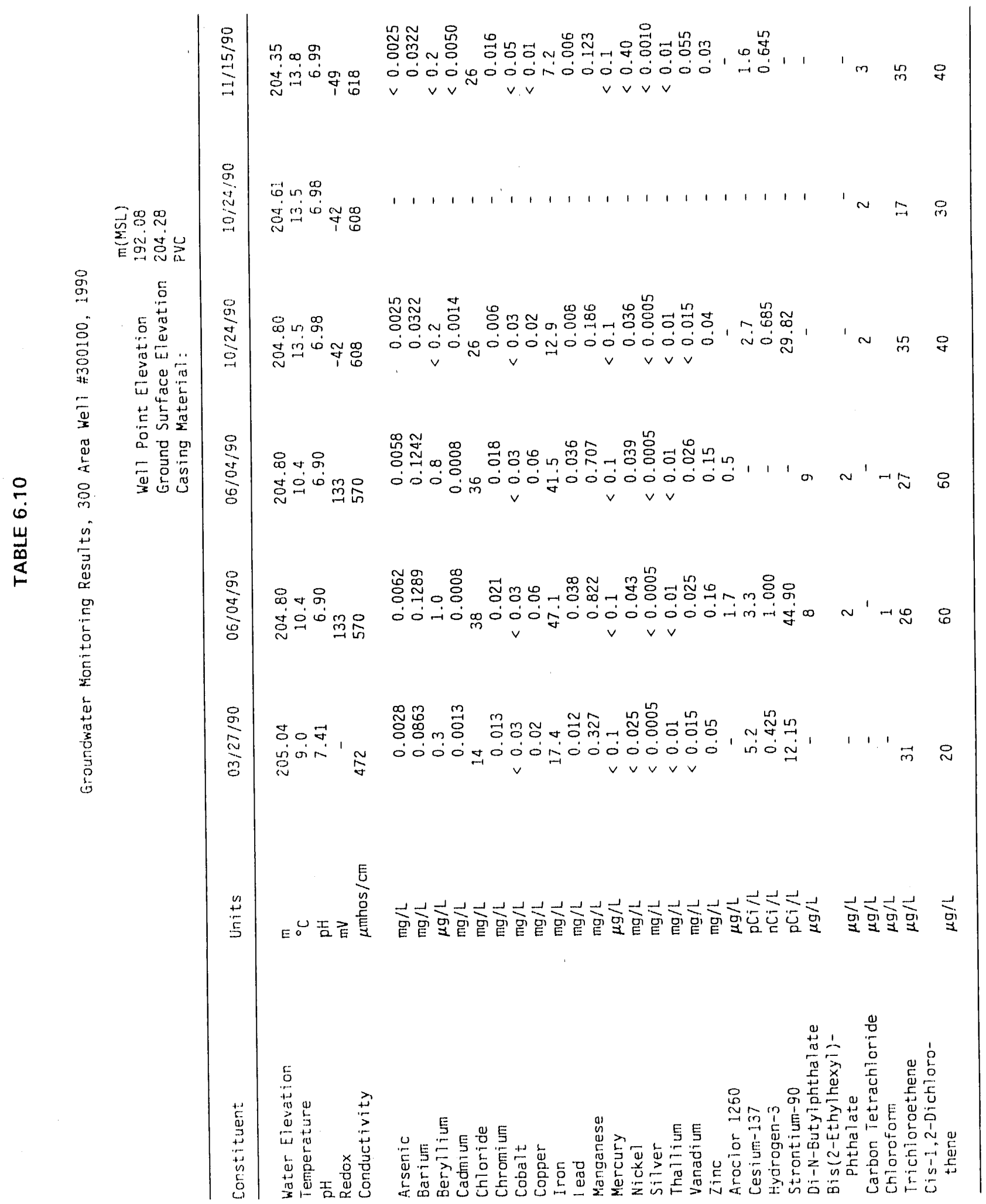


TABLE 6.11

Groundwater Monttoring Results, 300 Area We11 \#300110, 1990

\begin{tabular}{|c|c|c|c|c|c|}
\hline \multirow[b]{2}{*}{ Constituent } & \multirow[b]{2}{*}{ Units } & \multirow[b]{2}{*}{$03 / 27 / 90$} & \multicolumn{2}{|c|}{$\begin{array}{l}\text { We11 Point Elevation } \\
\text { Ground Surface Elevation } \\
\text { Casing Matertal: }\end{array}$} & \multirow{2}{*}{$\begin{array}{l}\mathrm{m}(\mathrm{MSL}) \\
199.16 \\
208.14 \\
\text { PVC } \\
11 / 15 / 90\end{array}$} \\
\hline & & & $06 / 04 / 90$ & $10 / 24 / 90$ & \\
\hline $\begin{array}{l}\text { Water Elevation } \\
\text { Temperature } \\
\text { pH } \\
\text { Redox } \\
\text { Conductivity }\end{array}$ & $\begin{array}{c}\mathrm{m}^{\circ} \\
{ }^{\circ} \mathrm{C} \\
\mathrm{mV} \\
\text { emhos/cm }\end{array}$ & $\begin{array}{c}204.42 \\
8.1 \\
7.34 \\
- \\
485\end{array}$ & $\begin{array}{l}204.25 \\
10.0 \\
6.97 \\
130 \\
513\end{array}$ & $\begin{array}{c}202.72 \\
14.6 \\
6.94 \\
-51 \\
594\end{array}$ & $\begin{array}{l}203.23 \\
14.5 \\
7.01 \\
-57 \\
584\end{array}$ \\
\hline $\begin{array}{l}\text { Arsenic } \\
\text { Barium } \\
\text { Beryllium } \\
\text { Cadmium } \\
\text { Chloride } \\
\text { Chromium } \\
\text { Cobalt } \\
\text { Copper } \\
\text { Iron } \\
\text { Lead } \\
\text { Manganese } \\
\text { Mercury } \\
\text { Nicke1 } \\
\text { Selenium } \\
\text { Silver } \\
\text { Thal1ium } \\
\text { Vanadium } \\
\text { Zinc } \\
\text { Cesium-137 } \\
\text { Hydrogen-3 } \\
\text { Strontium-90 } \\
\text { Di-N-Butylphthalate } \\
\text { Di-N-0ctyl Phthalate } \\
\text { Bis (2-Ethylhexy1)Phthalate } \\
1,1,1-\text { Trichloroethane } \\
\text { 1,1-Dichloroethane } \\
\text { Tetrachloroethene } \\
\text { Cis-1,2-Dichloroethene }\end{array}$ & $\begin{array}{l}\mathrm{mg} / \mathrm{L} \\
\mathrm{mg} / \mathrm{L} \\
\mu \mathrm{g} / \mathrm{L} \\
\mathrm{mg} / \mathrm{L} \\
\mathrm{mg} / \mathrm{L} \\
\mathrm{mg} / \mathrm{L} \\
\mathrm{mg} / \mathrm{L} \\
\mathrm{mg} / \mathrm{L} \\
\mathrm{mg} / \mathrm{L} \\
\mathrm{mg} / \mathrm{L} \\
\mathrm{mg} / \mathrm{L} \\
\mu \mathrm{g} / \mathrm{L} \\
\mathrm{mg} / \mathrm{L} \\
\mathrm{mg} / \mathrm{L} \\
\mathrm{mg} / \mathrm{L} \\
\mathrm{mg} / \mathrm{L} \\
\mathrm{mg} / \mathrm{L} \\
\mathrm{mg} / \mathrm{L} \\
\mathrm{pC} \mathrm{i} / \mathrm{L} \\
\mathrm{nCi} / \mathrm{L} \\
\mathrm{pCi} / \mathrm{L} \\
\mu \mathrm{g} / \mathrm{L} \\
\mu \mathrm{g} / \mathrm{L} \\
\mu \mathrm{g} / \mathrm{L} \\
\mu \mathrm{g} / \mathrm{L} \\
\mu \mathrm{g} / \mathrm{L} \\
\mu \mathrm{g} / \mathrm{L} \\
\mu \mathrm{g} / \mathrm{L}\end{array}$ & $\begin{array}{rl} & 0.0028 \\
0.1221 & 0.4 \\
& 0.0015 \\
8 \\
0.013 \\
<0.03 \\
0.03 \\
23.8 \\
0.022 \\
0.405 \\
<0.1 \\
<0.025 \\
<0.005 \\
<0.0005 \\
<0.01 \\
0.015 \\
0.08 \\
- \\
- \\
- \\
- \\
- \\
- \\
- \\
- \\
- \\
15\end{array}$ & $\begin{aligned} & 0.0039 \\
& 0.0969 \\
& 0.7 \\
& 0.0011 \\
& 7 \\
& 0.016 \\
&< 0.03 \\
& 0.05 \\
& 28.9 \\
& 0.046 \\
& 0.585 \\
&< 0.1 \\
&< 0.025 \\
&- \\
&< 0.0005 \\
&< 0.01 \\
& 0.021 \\
& 0.13 \\
&< 1 \\
& 0.123 \\
&< 0.25 \\
& 10 \\
& 6 \\
& 4 \\
& \quad- \\
&- \\
& 1 \\
&-\end{aligned}$ & $\begin{array}{c}<0.0025 \\
0.0556 \\
0.3 \\
0.0008 \\
11 \\
0.008 \\
0.03 \\
0.03 \\
21.1 \\
0.021 \\
0.452 \\
<0.1 \\
0.068 \\
- \\
<0.0005 \\
<0.01 \\
<0.015 \\
0.08 \\
- \\
- \\
- \\
- \\
- \\
- \\
1 \\
1 \\
- \\
4\end{array}$ & $\begin{array}{rl} & 0.0034 \\
& 0.0620 \\
< & 5.0 \\
< & 0.0050 \\
& 8 \\
& 0.025 \\
< & 0.05 \\
& 0.03 \\
19.1 & 0.014 \\
& 0.326 \\
< & 0.1 \\
< & 0.040 \\
< & - \\
< & 0.0100 \\
< & 0.01 \\
& 0.079 \\
& 0.08 \\
< & 1 \\
& 0.127 \\
< & 0.25 \\
& - \\
& - \\
- & - \\
& - \\
1 & - \\
& -\end{array}$ \\
\hline
\end{tabular}


TABLE 6.12

Groundwater Monftoring Results, 300 Area We11 \#300120, 1990

\begin{tabular}{|c|c|c|c|c|c|c|}
\hline \multirow[b]{2}{*}{ Constituent } & \multirow[b]{2}{*}{ Units } & \multirow[b]{2}{*}{$03 / 27 / 90$} & \multicolumn{3}{|c|}{$\begin{array}{l}\text { We } 11 \text { Point Elevation } \\
\text { Ground Surface Elevation } \\
\text { Casing Matertal: }\end{array}$} & \multirow{2}{*}{$\begin{array}{l}m(M S L) \\
198.66 \\
211.04 \\
\text { PVC } \\
\quad 11 / 15 / 90\end{array}$} \\
\hline & & & $03 / 27 / 90$ & $06 / 04 / 90$ & $08 / 28 / 90$ & \\
\hline $\begin{array}{l}\text { Water Elevation } \\
\text { Temperature } \\
\text { pH } \\
\text { Redox } \\
\text { Conductivity }\end{array}$ & $\begin{array}{l}{ }^{\mathrm{m}} \\
{ }^{\circ} \mathrm{C} \\
\mathrm{pH} \\
\mathrm{mV} \\
\mu \mathrm{mhos} / \mathrm{cm}\end{array}$ & $\begin{array}{c}202.26 \\
11.0 \\
7.08 \\
1315^{-}\end{array}$ & $\begin{array}{c}202.26 \\
11.0 \\
7.08 \\
1315\end{array}$ & $\begin{array}{c}204.40 \\
11.6 \\
6.69 \\
1270 \\
1390\end{array}$ & $\begin{array}{c}203.15 \\
13.4 \\
7.14 \\
-64 \\
1240\end{array}$ & $\begin{array}{c}202.63 \\
12.3 \\
6.80 \\
-53 \\
1461\end{array}$ \\
\hline $\begin{array}{l}\text { Arsenic } \\
\text { Barfum } \\
\text { Beryllium } \\
\text { Cadmium } \\
\text { Chloride } \\
\text { Chromium } \\
\text { Cobalt } \\
\text { Copper } \\
\text { Iron } \\
\text { Lead } \\
\text { Manganese } \\
\text { Mercury } \\
\text { Nickel } \\
\text { Silver } \\
\text { Thallium } \\
\text { Vanadium } \\
\text { Zinc } \\
\text { Cesium-137 } \\
\text { Hydrogen-3 } \\
\text { Strontium-90 } \\
\text { Chrysene } \\
\text { Di-N-Butylphalate } \\
\text { 2-Butanone }\end{array}$ & $\begin{array}{l}\mathrm{mg} / \mathrm{L} \\
\mathrm{mg} / \mathrm{L} \\
\mu \mathrm{g} / \mathrm{L} \\
\mathrm{mg} / \mathrm{L} \\
\mathrm{mg} / \mathrm{L} \\
\mathrm{mg} / \mathrm{L} \\
\mathrm{mg} / \mathrm{L} \\
\mathrm{mg} / \mathrm{L} \\
\mathrm{mg} / \mathrm{L} \\
\mathrm{mg} / \mathrm{L} \\
\mathrm{mg} / \mathrm{L} \\
\mu \mathrm{g} / \mathrm{L} \\
\mathrm{rr} / \mathrm{L} \\
\mathrm{in} / \mathrm{L} \\
\mathrm{mg} / \mathrm{L} \\
\mathrm{mg} / \mathrm{L} \\
\mathrm{mg} / \mathrm{L} \\
\mathrm{pC} j / \mathrm{L} \\
\mathrm{nCi} \mathrm{i} / \mathrm{L} \\
\mathrm{pC} \dagger / L \\
\mu \mathrm{g} / \mathrm{L} \\
\mu \mathrm{g} / \mathrm{L} \\
\mu \mathrm{g} / \mathrm{L}\end{array}$ & $\begin{aligned} & 0.0208 \\
& 0.4153 \\
& 2.2 \\
& 0.0059 \\
& 2.78 \\
& 0.087 \\
& 0.08 \\
& 0.02 \\
& 180.3 \\
& 0.111 \\
& 3.190 \\
&<0.1 \\
& 0.189 \\
&<0.0005 \\
&<0.01 \\
& 0.047 \\
& 0.42 \\
&<1 \\
& 0.235 \\
&<0.25 \\
&- \\
&- \\
&- \\
&-\end{aligned}$ & $\begin{aligned} 0.0279 \\
0.5650 \\
3.3 \\
0.0040 \\
269 \\
0.110 \\
0.14 \\
0.04 \\
299.9 \\
0.134 \\
4.940 \\
<0.1 \\
0.302 \\
<0.0005 \\
<0.01 \\
0.060 \\
0.72 \\
- \\
- \\
- \\
- \\
- \\
- \\
-\end{aligned}$ & $\begin{aligned} & 0.0108 \\
& 0.1251 \\
& 0.6 \\
& 0.0012 \\
& 337 \\
& 0.014 \\
&<0.03 \\
& 0.04 \\
& 27.7 \\
& 0.025 \\
& 0.510 \\
&<0.1 \\
& 0.031 \\
&<0.0005 \\
&<0.01 \\
& 0.018 \\
& 0.11 \\
&<1 \\
& 0.113 \\
&<0.25 \\
& \quad- \\
&- \\
&-\end{aligned}$ & $\begin{aligned} & 0.0080 \\
& 0.0977 \\
& 0.4 \\
& 0.0032 \\
& 219 \\
& 0.012 \\
& 0.04 \\
& 0.03 \\
& 18.7 \\
& 0.017 \\
& 0.403 \\
&< 0.1 \\
& 0.081 \\
&< 0.0005 \\
&< 0.01 \\
& 0.015 \\
& 0.06 \\
&< 1 \\
& 0.316 \\
&< 0.25 \\
& 5 \\
& 2 \\
&-\end{aligned}$ & $\begin{aligned} & 0.0079 \\
& 0.1030 \\
< & 5.0 \\
< & 0.0050 \\
& 319 \\
& 0.029 \\
< & 0.05 \\
& 0.02 \\
& 28.0 \\
& 0.020 \\
& 0.585 \\
< & 0.1 \\
< & 0.040 \\
< & 0.0100 \\
< & 0.01 \\
& 0.064 \\
& 0.08 \\
< & 1 \\
& 0.162 \\
< & 0.25 \\
& - \\
& - \\
& 8\end{aligned}$ \\
\hline
\end{tabular}


TABLE 6.13

Groundwater Monttoring Results, 300 Area We11 \#300130, 1990

\begin{tabular}{|c|c|c|c|c|c|}
\hline \multirow[b]{2}{*}{ Constituent } & \multirow[b]{2}{*}{ Units } & \multicolumn{3}{|c|}{$\begin{array}{l}\text { We11 Point Elevation } \\
\text { Ground Surface Elevation } \\
\text { Casing Matertal: }\end{array}$} & \multirow{2}{*}{$\begin{array}{l}\mathrm{m}(\mathrm{MSL}) \\
200.72 \\
213.02 \\
\mathrm{PVC} \\
11 / 16 / 90\end{array}$} \\
\hline & & $03 / 27 / 90$ & $06 / 05 / 90$ & $08 / 29 / 90$ & \\
\hline $\begin{array}{l}\text { Water Elevation } \\
\text { Temperature } \\
\mathrm{pH} \\
\text { Redox } \\
\text { Conductivity }\end{array}$ & $\begin{array}{l}{ }_{{ }^{\circ}}^{\mathrm{m}} \\
\mathrm{pH} \\
\mathrm{mV} \\
\mu \mathrm{mhos} / \mathrm{cm}\end{array}$ & $\begin{array}{c}206.24 \\
10.8 \\
7.32 \\
- \\
-\end{array}$ & $\begin{array}{l}207.57 \\
10.2 \\
6.47 \\
76 \\
750\end{array}$ & $\begin{array}{l}205.26 \\
12.3 \\
6.91 \\
49 \\
753\end{array}$ & $\begin{array}{l}204.73 \\
11.9 \\
7.04 \\
-39 \\
778\end{array}$ \\
\hline $\begin{array}{l}\text { Arsenic } \\
\text { Barlum } \\
\text { Berylitum } \\
\text { Cadmium } \\
\text { Chloride } \\
\text { Chromium } \\
\text { Cobalt } \\
\text { Copper } \\
\text { Iron } \\
\text { Lead } \\
\text { Manganese } \\
\text { Mercury } \\
\text { Nicke1 } \\
\text { Selentum } \\
\text { Silver } \\
\text { Thallium } \\
\text { Vanadium } \\
\text { Zinc } \\
\text { Aroclor } 1254 \\
\text { Cesium-137 } \\
\text { Hydrogen-3 } \\
\text { Strontium-90 } \\
\text { Chrysene } \\
\text { Di-N-Butylphthalate }\end{array}$ & $\begin{array}{l}\mathrm{mg} / \mathrm{L} \\
\mathrm{mg} / \mathrm{L} \\
\mu \mathrm{g} / \mathrm{L} \\
\mathrm{mg} / \mathrm{L} \\
\mathrm{mg} / \mathrm{L} \\
\mathrm{mg} / \mathrm{L} \\
\mathrm{mg} / \mathrm{L} \\
\mathrm{mg} / \mathrm{L} \\
\mathrm{mg} / \mathrm{L} \\
\mathrm{mg} / \mathrm{L} \\
\mathrm{mg} / \mathrm{L} \\
\mu \mathrm{g} / \mathrm{L} \\
\mathrm{mg} / \mathrm{L} \\
\mathrm{mg} / \mathrm{L} \\
\mathrm{mg} / \mathrm{L} \\
\mathrm{mg} / \mathrm{L} \\
\mathrm{mg} / \mathrm{L} \\
\mathrm{mg} / \mathrm{L} \\
\mathrm{mg} / \mathrm{L} \\
\mathrm{pCi} \mathrm{i} / \mathrm{L} \\
\mathrm{nCi} \mathrm{i} / \mathrm{L} \\
\mathrm{pCi} / \mathrm{L} \\
\mu \mathrm{g} / \mathrm{L} \\
\mu \mathrm{g} / \mathrm{L}\end{array}$ & $\begin{aligned}< & 0.0025 \\
& 0.1033 \\
< & 0.2 \\
< & 0.0003 \\
& 84 \\
< & 0.004 \\
< & 0.03 \\
< & 0.01 \\
& 1.3 \\
& 0.021 \\
& 0.115 \\
< & 0.1 \\
< & 0.025 \\
< & 0.005 \\
< & 0.0005 \\
< & 0.01 \\
< & 0.015 \\
& 0.01 \\
< & - \\
< & 1 \\
& 0.186 \\
< & 0.25 \\
& - \\
& -\end{aligned}$ & $\begin{aligned}< & 0.0025 \\
& 0.0808 \\
< & 0.2 \\
< & 0.0003 \\
& 91 \\
< & 0.004 \\
< & 0.03 \\
< & 0.01 \\
& 0.9 \\
& 0.006 \\
& 0.081 \\
< & 0.1 \\
< & 0.025 \\
< & - \\
< & 0.0005 \\
< & 0.01 \\
< & 0.015 \\
& 0.03 \\
< & - \\
< & 0.124 \\
< & 0.25 \\
& - \\
& -\end{aligned}$ & $\begin{aligned} &< 0.0025 \\
& 0.0889 \\
&< 0.2 \\
& 0.0005 \\
& 94 \\
&< 0.004 \\
&< 0.03 \\
&< 0.01 \\
& 0.8 \\
&< 0.002 \\
& 0.077 \\
&< 0.1 \\
& 0.077 \\
&<- \\
&< 0.0005 \\
&< 0.01 \\
&< 0.015 \\
& 0.01 \\
& 13 \\
&< 1 \\
& 1.645 \\
&- \\
& 3 \\
& 6\end{aligned}$ & $\begin{aligned} &< 0.0025 \\
& 0.0590 \\
&< 5.0 \\
&< 0.0050 \\
& 102<0.010 \\
&< 0.05 \\
&< 0.01 \\
& 0.6 \\
&< 0.002 \\
& 0.076 \\
&< 0.1 \\
&< 0.040 \\
&<- \\
&<0.0100 \\
&<0.01 \\
&<0.050 \\
&<0.01 \\
&<1 \\
&<1 \\
& 1.100 \\
&<0.25 \\
& \quad- \\
&-\end{aligned}$ \\
\hline
\end{tabular}


TABLE 6.14

Groundwater Monttoring Results, 300 Area We11 \#300D03, 1990

\begin{tabular}{|c|c|c|c|c|c|}
\hline \multirow[b]{2}{*}{ Constituent } & \multirow[b]{2}{*}{ Units } & \multirow[b]{2}{*}{$03 / 26 / 90$} & \multicolumn{2}{|c|}{$\begin{array}{l}\text { Well point Elevation } \\
\text { Ground Surface Elevation } \\
\text { Casing Matertal: }\end{array}$} & \multirow{2}{*}{$\begin{array}{l}m(M S L) \\
183.17 \\
207.57 \\
\text { PVC } \\
11 / 15 / 90\end{array}$} \\
\hline & & & $06 / 04 / 90$ & $08 / 29 / 90$ & \\
\hline $\begin{array}{l}\text { Water Elevation } \\
\text { Temperature } \\
\text { pH } \\
\text { Redox } \\
\text { Conductivity }\end{array}$ & $\begin{array}{c}\mathrm{m}^{\mathrm{o}} \\
{ }^{\circ} \mathrm{C} \\
\mathrm{pH} \\
\mathrm{mV} \\
\text { umhos/cm }\end{array}$ & $\begin{array}{c}186.59 \\
11.0 \\
9.63 \\
558^{-}\end{array}$ & $\begin{array}{l}186.32 \\
10.8 \\
10.69 \\
75 \\
585\end{array}$ & $\begin{array}{c}186.37 \\
11.8 \\
8.66 \\
-59 \\
542\end{array}$ & $\begin{array}{c}186.32 \\
11.6 \\
10.82 \\
-119 \\
558\end{array}$ \\
\hline $\begin{array}{l}\text { Arsentc } \\
\text { Bartum } \\
\text { Beryllitum } \\
\text { Cadmium } \\
\text { Chloride } \\
\text { Chromium } \\
\text { Cobalt } \\
\text { Copper } \\
\text { Iron } \\
\text { Lead } \\
\text { Manganese } \\
\text { Mercury } \\
\text { Nickel } \\
\text { Selenium } \\
\text { Silver } \\
\text { Thallium } \\
\text { Vanadium } \\
\text { Zinc } \\
\text { Cesium-137 } \\
\text { Hydrogen-3 } \\
\text { Strontium-90 } \\
\text { Di-N-Butylphthalate } \\
\text { Bis(2-Ethylhexyl)Phthalate } \\
\text { 2-Butanone } \\
\text { Acetone }\end{array}$ & $\begin{array}{l}\mathrm{mg} / \mathrm{L} \\
\mathrm{mg} / \mathrm{L} \\
\mu \mathrm{g} / \mathrm{L} \\
\mathrm{mg} / \mathrm{L} \\
\mathrm{mg} / \mathrm{L} \\
\mathrm{mg} / \mathrm{L} \\
\mathrm{mg} / \mathrm{L} \\
\mathrm{mg} / \mathrm{L} \\
\mathrm{mg} / \mathrm{L} \\
\mathrm{mg} / \mathrm{L} \\
\mathrm{mg} / \mathrm{L} \\
\mu \mathrm{g} / \mathrm{L} \\
\mathrm{mg} / \mathrm{L} \\
\mathrm{mg} / \mathrm{L} \\
\mathrm{mg} / \mathrm{L} \\
\mathrm{mg} / \mathrm{L} \\
\mathrm{mg} / \mathrm{L} \\
\mathrm{mg} / \mathrm{L} \\
\mathrm{pCH} / \mathrm{L} \\
\mathrm{nCH} / \mathrm{L} \\
\mathrm{pC} \gamma / \mathrm{L} \\
\mu \mathrm{g} / \mathrm{L} \\
\mu \mathrm{g} / \mathrm{L} \\
\mu \mathrm{g} / \mathrm{L} \\
\mu \mathrm{g} / \mathrm{L}\end{array}$ & $\begin{aligned}< & 0.0025 \\
& 0.0370 \\
< & 0.2 \\
< & 0.0003 \\
& 36 \\
< & 0.004 \\
< & 0.03 \\
< & 0.01 \\
& 2.2 \\
& 0.010 \\
& 0.016 \\
< & 0.1 \\
< & 0.025 \\
< & 0.005 \\
< & 0.0005 \\
< & 0.01 \\
< & 0.015 \\
< & 0.01 \\
< & 1 \\
& 0.165 \\
< & 0.25 \\
& - \\
& - \\
& - \\
& -\end{aligned}$ & $\begin{aligned}< & 0.0025 \\
& 0.0863 \\
< & 0.2 \\
& 0.0004 \\
& 42 \\
< & 0.004 \\
< & 0.03 \\
& 0.01 \\
& 1.2 \\
& 0.007 \\
< & 0.015 \\
< & 0.1 \\
< & 0.025 \\
< & 0.0005 \\
< & 0.01 \\
< & 0.015 \\
< & 0.01 \\
< & 1 \\
& 0.100 \\
< & 0.25 \\
& 5 \\
& 1 \\
& 6 \\
& 14\end{aligned}$ & $\begin{aligned} &< 0.0025 \\
& 0.0199 \\
&< 0.2 \\
& 0.0023 \\
& 37 \\
& 0.005 \\
&< 0.03 \\
&< 0.01 \\
& 1.3 \\
&< 0.002 \\
& 0.016 \\
&< 0.1 \\
& 0.069 \\
&- \\
&< 0.0005 \\
&< 0.01 \\
&< 0.015 \\
& 0.01 \\
&< 1 \\
& 0.203 \\
&< 0.25 \\
&- \\
&-- \\
&-\end{aligned}$ & $\begin{aligned}< & 0.0025 \\
& 0.0170 \\
< & 5.0 \\
< & 0.0050 \\
& 39 \\
< & 0.010 \\
< & 0.05 \\
< & 0.01 \\
& 3.4 \\
< & 0.002 \\
& 0.034 \\
< & 0.1 \\
< & 0.040 \\
< & - \\
< & 0.0100 \\
< & 0.01 \\
< & 0.050 \\
< & 0.01 \\
< & 1 \\
0.164 & <0.25 \\
& - \\
& - \\
& 7 \\
& 13\end{aligned}$ \\
\hline
\end{tabular}


TABLE 6.15

Groundwater Monttoring Results, 300 Area We11 \#300D04, 1990

m(MSL)

We11 Point Elevation 182.06

Ground Surface Elevation 203.56

Casting Materlal: PVC

\begin{tabular}{|c|c|c|c|c|c|}
\hline Constituent & Untts & $03 / 26 / 90$ & $06 / 04 / 90$ & $08 / 29 / 90$ & $11 / 15 / 90$ \\
\hline $\begin{array}{l}\text { Water Elevation } \\
\text { Temperature } \\
\text { pH } \\
\text { Redox } \\
\text { Conductivity }\end{array}$ & $\begin{array}{c}{ }^{\mathrm{m}} \\
{ }^{\circ} \mathrm{C} \\
\mathrm{pH} \\
\mathrm{mV} \\
\mu \mathrm{mhos} / \mathrm{cm}\end{array}$ & $\begin{array}{l}186.64 \\
10.5 \\
9.57 \\
394\end{array}$ & $\begin{array}{l}184.81 \\
11.5 \\
11.16 \\
130 \\
320\end{array}$ & $\begin{array}{l}184.47 \\
12.1 \\
7.75 \\
8 \\
403\end{array}$ & $\begin{array}{c}184.41 \\
11.3 \\
9.27 \\
-121 \\
385\end{array}$ \\
\hline $\begin{array}{l}\text { Arsentc } \\
\text { Bartum } \\
\text { Beryllium } \\
\text { Cadmium } \\
\text { Chloride } \\
\text { Chromium } \\
\text { Cobalt } \\
\text { Copper } \\
\text { Iron } \\
\text { Lead } \\
\text { Manganese } \\
\text { Mercury } \\
\text { Nickel } \\
\text { Selentum } \\
\text { Silver } \\
\text { Thallium } \\
\text { Vanadium } \\
\text { Zinc } \\
\text { Cesium-137 } \\
\text { Hydrogen-3 } \\
\text { Strontium-90 } \\
\text { Di-N-Butylphthalate } \\
\text { Bis(2-Ethylhexyl)Phthalate }\end{array}$ & $\begin{array}{l}\mathrm{mg} / \mathrm{L} \\
\mathrm{mg} / \mathrm{L} \\
\mu \mathrm{g} / \mathrm{L} \\
\mathrm{mg} / \mathrm{L} \\
\mathrm{mg} / \mathrm{L} \\
\mathrm{mg} / \mathrm{L} \\
\mathrm{mg} / \mathrm{L} \\
\mathrm{mg} / \mathrm{L} \\
\mathrm{mg} / \mathrm{L} \\
\mathrm{mg} / \mathrm{L} \\
\mathrm{mg} / \mathrm{L} \\
\mu \mathrm{g} / \mathrm{L} \\
\mathrm{mg} / \mathrm{L} \\
\mathrm{mg} / \mathrm{L} \\
\mathrm{mg} / \mathrm{L} \\
\mathrm{mg} / \mathrm{L} \\
\mathrm{mg} / \mathrm{L} \\
\mathrm{mg} / \mathrm{L} \\
\mathrm{pCj} / \mathrm{L} \\
\mathrm{nCi} / \mathrm{L} \\
\mathrm{pCi} / \mathrm{L} \\
\mu \mathrm{g} / \mathrm{L} \\
\mathrm{te} \mathrm{g} / \mathrm{L}\end{array}$ & $\begin{aligned}< & 0.0025 \\
& 0.0400 \\
< & 0.2 \\
< & 0.0003 \\
& 21 \\
& 0.038 \\
< & 0.03 \\
< & 0.01 \\
& 0.9 \\
& 0.013 \\
& 0.022 \\
< & 0.1 \\
< & 0.025 \\
< & 0.005 \\
< & 0.0005 \\
< & 0.01 \\
< & 0.015 \\
& 0.03 \\
< & 1 \\
& 0.915 \\
< & 0.25 \\
& - \\
& -\end{aligned}$ & $\begin{aligned} &< 0.0025 \\
& 0.0431 \\
&< 0.2 \\
& 0.0007 \\
& 29 \\
& 0.025 \\
&< 0.03 \\
& 0.01 \\
& 0.4 \\
& 0.004 \\
& 0.015 \\
&< 0.1 \\
&< 0.025 \\
&<- \\
&< 0.0005 \\
&< 0.01 \\
&< 0.015 \\
& 0.14 \\
&< 1 \\
& 0.763 \\
&<0.25 \\
& 6 \\
& 2\end{aligned}$ & $\begin{aligned} &< 0.0025 \\
& 0.0347 \\
&< 0.2 \\
& 0.0005 \\
& 36 \\
& 0.010 \\
&< 0.03 \\
&< 0.01 \\
& 0.3 \\
&< 0.002 \\
&< 0.015 \\
&< 0.1 \\
& 0.049 \\
&<- \\
&< 0.0005 \\
&< 0.01 \\
&< 0.015 \\
& 0.01 \\
&< 1 \\
& 1.000 \\
&< 0.25 \\
&- \\
&-\end{aligned}$ & $\begin{aligned}< & 0.0025 \\
& 0.0510 \\
< & 5.0 \\
< & 0.0050 \\
& 36 \\
& 0.017 \\
< & 0.05 \\
< & 0.01 \\
& 0.2 \\
< & 0.002 \\
& 0.025 \\
< & 0.1 \\
< & 0.040 \\
< & - \\
< & 0.0100 \\
< & 0.01 \\
< & 0.050 \\
< & 0.01 \\
< & 1 \\
& 1.100 \\
< & 0.25 \\
& - \\
& -\end{aligned}$ \\
\hline
\end{tabular}


Field Results

The purging of wells to produce water representative of the groundwater being studied is followed by measuring the field parameters. For a normal well, the temperature and specific conductance do not change after one well volume is removed. The $\mathrm{pH}$ is somewhat variable through 3-5 well volumes but the final $\mathrm{pH}$ is about their average. The redox potential changes radically after two well volumes are removed and then becomes constant. This is the situation for the wells reported in this study. On the basis of this information, sampling is conducted after the removal of three well volumes. The parameters listed in the tables are the final readings obtained at the time of sampling.

\section{Inorganic Results}

None of the inorganic results were above ambient levels, except for several samples from wells 300030, 300052, 300100, and 300120, which have elevated lead and chromium concentrations. Wells 300052, 300100, 300110, and 300120 are located in the same layer of water. The levels of lead range from $5.0 \mu \mathrm{g} / \mathrm{L}$ to $134 \mu \mathrm{g} / \mathrm{L}$, while the levels in the other wells are less than $10 \mu \mathrm{g} / \mathrm{L}$. The levels of chromium in these same wells range from 5 to 120 $\mu \mathrm{g} / \mathrm{L}$ while the levels in the other wells are less than $10 \mu \mathrm{g} / \mathrm{L}$. There are elevated levels of iron in several wells but the significance of these levels is not known. The source of the elevated chromium and lead levels is unknown. Elevated levels of lead were reported in the last annual report. ${ }^{13}$ The results obtained for the dolomite well samples are within the normal range for water of this type with the exception of chromium which is slightly elevated. The chloride levels are in the range of 21 to $42 \mathrm{mg} / \mathrm{L}$, which are similar to the chloride concentrations in the four drinking water wells.

\section{Organic Results}

Each well was sampled quarterly and analyzed for volatile organic compounds. Once during the year the wells were sampled and analyzed for semivolatile organic compounds, polychlorinated biphenyls (PCBs) and 
pesticides and herbicides. When results exceeding the required detection limits were obtained for these analyses, the sampling and analysis were repeated. Volatile organic compounds were detected in wells 300020, 300030, 300100,300110 , and 300003. The levels of volatile organics are persistent and appear to be indicative of different sources of contamination.

The results for well 300020 are shown in Figure 6.3. The major components are 1,1,1-trichloroethane(TCA) and 1,1-dichloroethane, which can be a decomposition product of TCA. As can be seen, the concentrations roughly parallel each other and the levels found are remarkably constant for this extended time period. The consistency would indicate that this well is sampling a large area of contaminated water which is unaffected by seasonal water level changes. Trace levels of chloroform and carbon tetrachloride are frequently found in this well. The well is immediately below the plugged sewer line previously discussed and this sewer line is known to be contaminated with these two compounds, but not the other constituents found in this well.

Wells 300100 and 300110 are adjacent to the storage vaults and are close to one another. The chemical characteristics are quite dissimilar. The principal volatile organic compounds found in wel1 300100 are trichloroethene (TCE) and cis-1,2-dichloroethene (1,2-DCE). The results obtained from the beginning of sampling until the end of 1990 are shown in Figure 6.4. When TCE breaks down in the presence of soil bacteria, the cis isomer of 1,2-DCE is produced almost exclusively. Indeed, only trace amounts of the trans isomer are seen in these samples and one can assume that the TCE is the parent of the 1,2-DCE. The fact that they are both present in these samples at relatively stable concentrations indicates that there may be ongoing release of TCE into the ground water, such as from highly contaminated soil. The half life for the conversion indicated is about 30 days. The end product of this conversion is vinyl chloride which has a half life of 26,000 days. Vinyl chloride has never been detected in these samples. chloroform, carbon tetrachloride, and tetrachloroethene are occasionally found in trace amounts in this well. In contrast, the levels and variety of volatile organics found in well 300110 are quite variable. In the initial samples obtained in 1988 very high amounts of 1,1,1,-trichloroethane and 

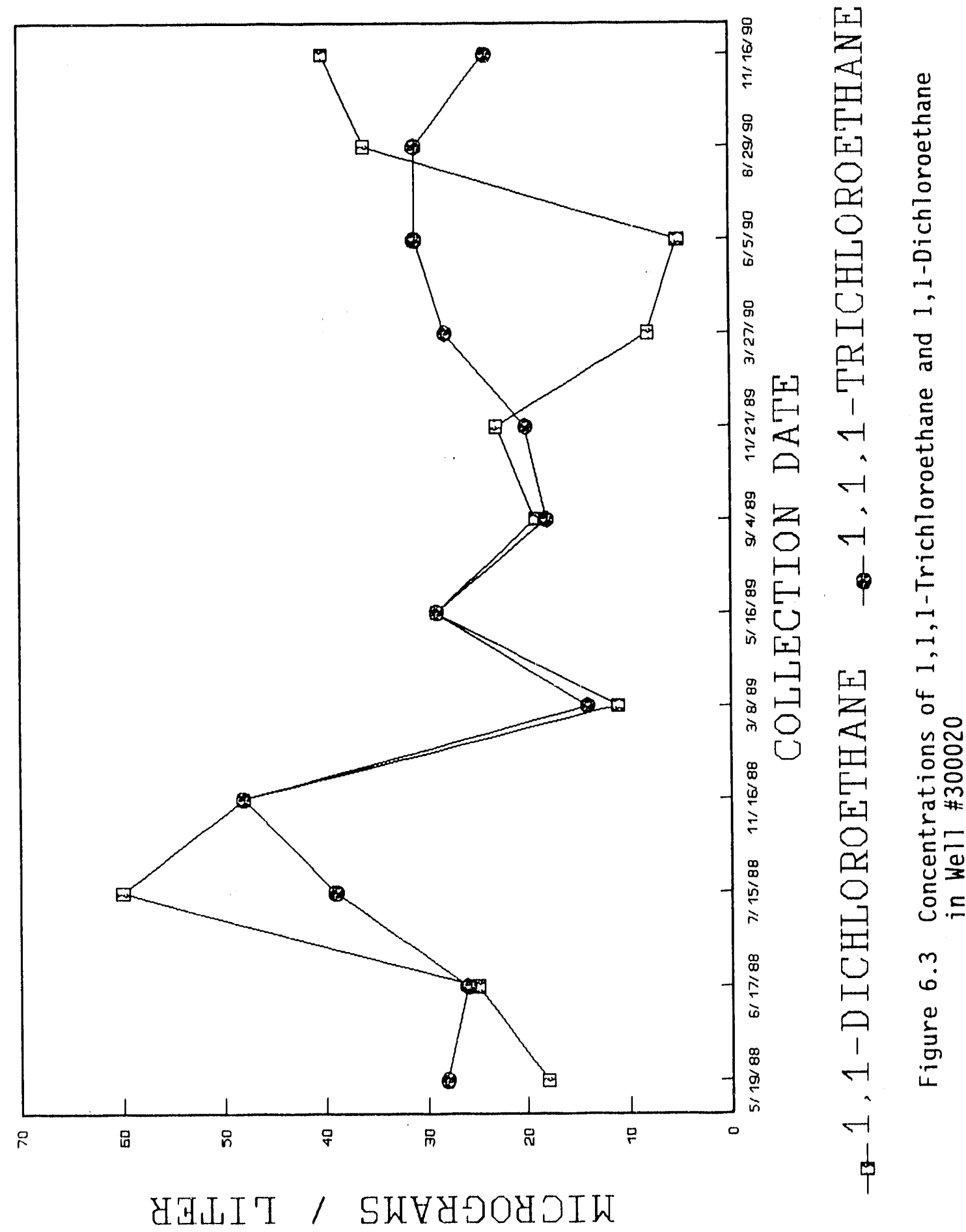


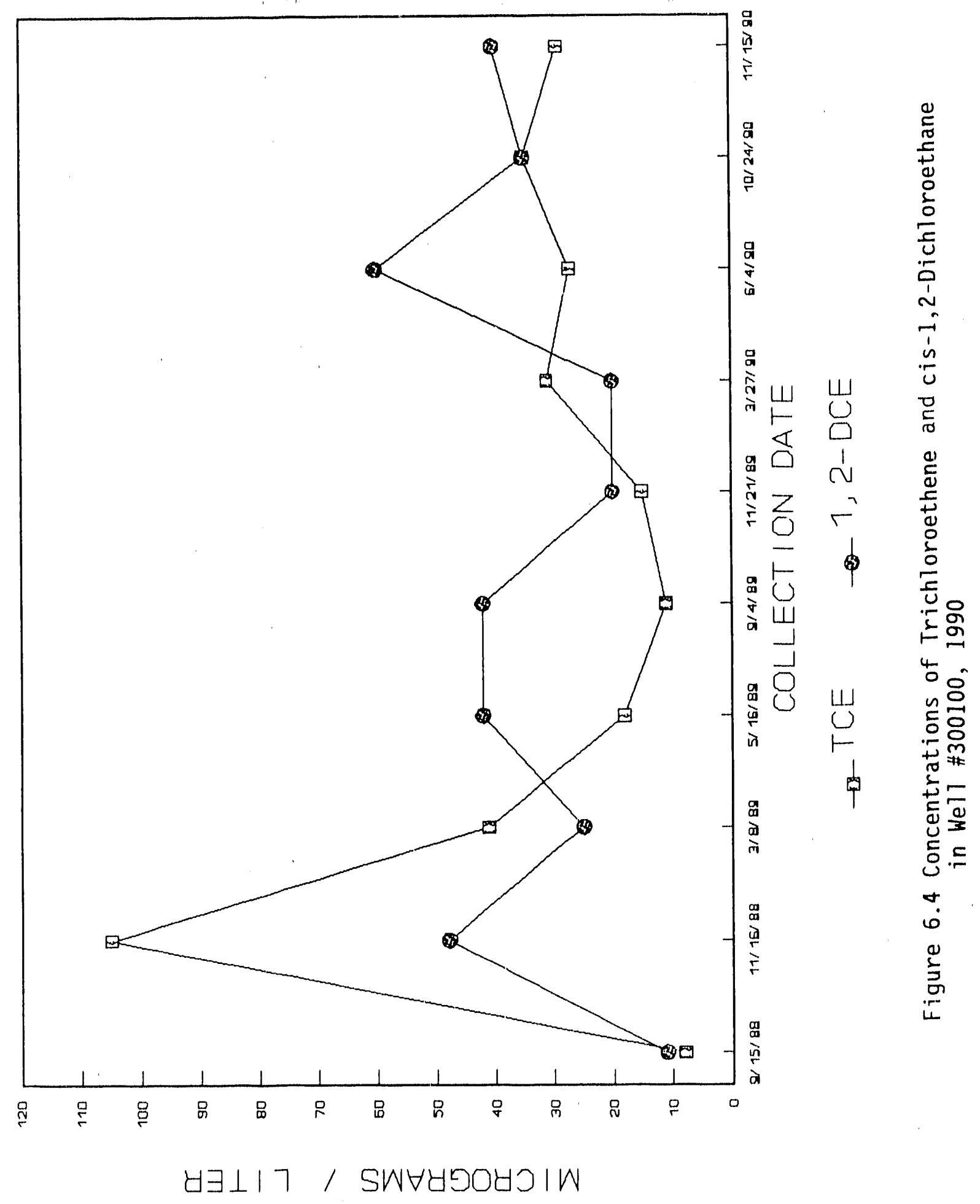


1,1-dichloroethane (170 and $160 \mu \mathrm{g} / \mathrm{L}$, respectively) were found. In subse-

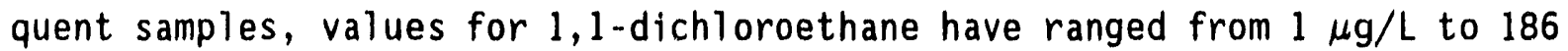
$\mu \mathrm{g} / \mathrm{L}$ and values for 1,1,1-trichloroethane have ranged from $1 \mu \mathrm{g} / \mathrm{L}$ to 31 $\mu \mathrm{g} / \mathrm{L}$. Trichloroethene, tetrachloroethene and 1,2-dichloroethane have also been detected on occasion.

Samples obtained in 1990 from dolomite well 300003 have contained acetone and 2-butanone on a consistent basis. Samples from previous years did not indicate the presence of these ketones. Other studies conducted at the 319 Area, discussed in Section 6.5., indicate that ketones are able to move through the glacial till at a much nigher rate than other organics. Their presence in the dolomite aquifer indicates that the waste chemicals placed in the French drain may be moving through the glacial till, into the dolomite aquifer.

Samples were obtained from well 300030 in the last three quarters of 1990. Trichloroethene was found in all three samples at essentially the same level. 1,1,1-trichloroethane was found in two of the samples as was chloroform. This weli is frequently dry but it contains organic constituents when water is precent.

Aroclor 1254 was reported in samples obtained in August from wells 300052, 300120, and 300130. Samples taken previously to and subsequent to this sample did not indicate the presence of the aroclors. The reasons for these results are not known. PCBs were found at about the $1 \mu \mathrm{g} / \mathrm{L}$ detection limit in dolomite well 300004. A second sample was obtained and the same level of PCBs was found although Aroclor 1260 was found in one case ar. 1254 found in the other. This well will be resampled until the situation is better defined. PCBs have been found in the 319 Area 1 andfill.

Semivolatile organics and pesticides/herbicides, with the exception of several phthalates and chrysene, were not detected in any of the wells. The phthalates and chrysenes were found in most of the samples and the blanks. Their presence may be due to Laboratory procedural problems. 


\section{Radioactive Constituents}

Samples collected quarterly from the monitoring wells in the 317 and 319 Areas were analyzed for hydrogen-3, strontium-90, and for gamma-ray emitters. The results are presented in Tables 6.4 to 6.15 . The only evidence of possible migration of radionuclides off the site is the low concentrations of hydrogen-3 in wells 300030, 300031, and 300D04, which are 10cated near the south perimeter fence. A small amount of strontium-90 was also detected in well 300030 . These monitoring wells are directly below a small drainage swale from the 319 Area that has contained water intermittently with measurable concentrations of hydrogen-3 and strontium-90. Well 300100 contains measurable levels of hydrogen-3, strontium-90, and cesium137, while well 300110 contains strontium-90. These wells are next to facilities that have stored radioactive materials in the past. All concentrations are well below any applicable standards.

\subsection{Sanitary Landfill}

The 800 Area is the site of ANL's sanitary landfill. The 21.8-acre landfill is located on the western edge of ANL property (Figure 1.1). The 1 andfill has received waste since 1966 and operates under IEPA permit No. 1981-29-OP which was issued on September 17, 1981. The landfill currently receives general refuse, construction debris, boiler house ash, and other nonradioactive solid waste.

\subsubsection{French Drain}

The landfill area was used for the disposal of certain types of 1 iquid wastes from 1969 to 1978. The wastes were poured into a French drain which consisted of a corrugated steel pipe placed in a gravel-filled pit dug into an area previously filled with waste. The liquid waste was poured into the drain and allowed to permeate into the gravel and thence into the soil and fill material. There is documentation available that indicates that 29,000 gallons of liquid waste were placed in this drain. Many of the wastes disposed of in this manner are now regarded as hazardous wastes. The presence of volatile and other toxic organic compounds has been confirmed by 
soil gas surveys conducted at the landfill. Measurable amounts of these materials were identified in soil vapors and in shallow groundwater of the landfill. These findings are discussed further in Section 6.5.

\subsubsection{Monitoring Studies}

In 1979, an investigation was conducted to determine the subsurface characteristics of the site and to place monitoring wells around the landfill (see Figure 6.5). The topography and initial studies indicated that water flow was primarily southerly. We11s 800010 and 800050 were located outside the landfill and were meant to measure water entering and leaving the landfill. Wells 800020,800030 , and 800040 were placed at the perimeter of the 1andfi11. In April 1980, a more comprehensive study was initiated to develop information required for the State of Illinois operating permit. ${ }^{22}$ Three additional wells were placed at the perimeter to improve coverage as well as to measure vertical movement. Well 800060 was placed in the eastern section to sample any water flowing out of the landfill in a southeasterly direction. Wells 800070 and 800071 were located along the southern boundary and were nested. In September 1986, six new wells were installed. Wells 800010,800020 , and 800040 were suspected of being poorly sealed and were removed and replaced by 800012,800022 and 800042 . The replacement wells were located within $2 \mathrm{~m}(6 \mathrm{ft})$ of the original wells. In addition, wells 800080,800090 , and 800100 were constructed to improve peripheral coverage. In November 1987, additional wells were added to provide sampling at a deeper level. We11 800120, which is next to 800060 , and well 800130 , which is next to 800090 , were both installed to a depth of $24 \mathrm{~m}(80 \mathrm{ft})$. Finally, in September 1989, two wells (800001 and 800002) were placed into the dolomite at a depth of $45 \mathrm{~m}(140 \mathrm{ft})$.

\subsubsection{Sample Collection}

The same procedure for well water sample collection previously described for the 300 Area was used for this area. Previous water level measurements have indicated that a perched water layer exists at a depth of about $6 \mathrm{~m}(20 \mathrm{ft})$ on the north to about $7.6 \mathrm{~m}(25 \mathrm{ft})$ on the south. Wells 800012 through 800100 sample this layer. Wells $800: 20$ and 800130 , which are 


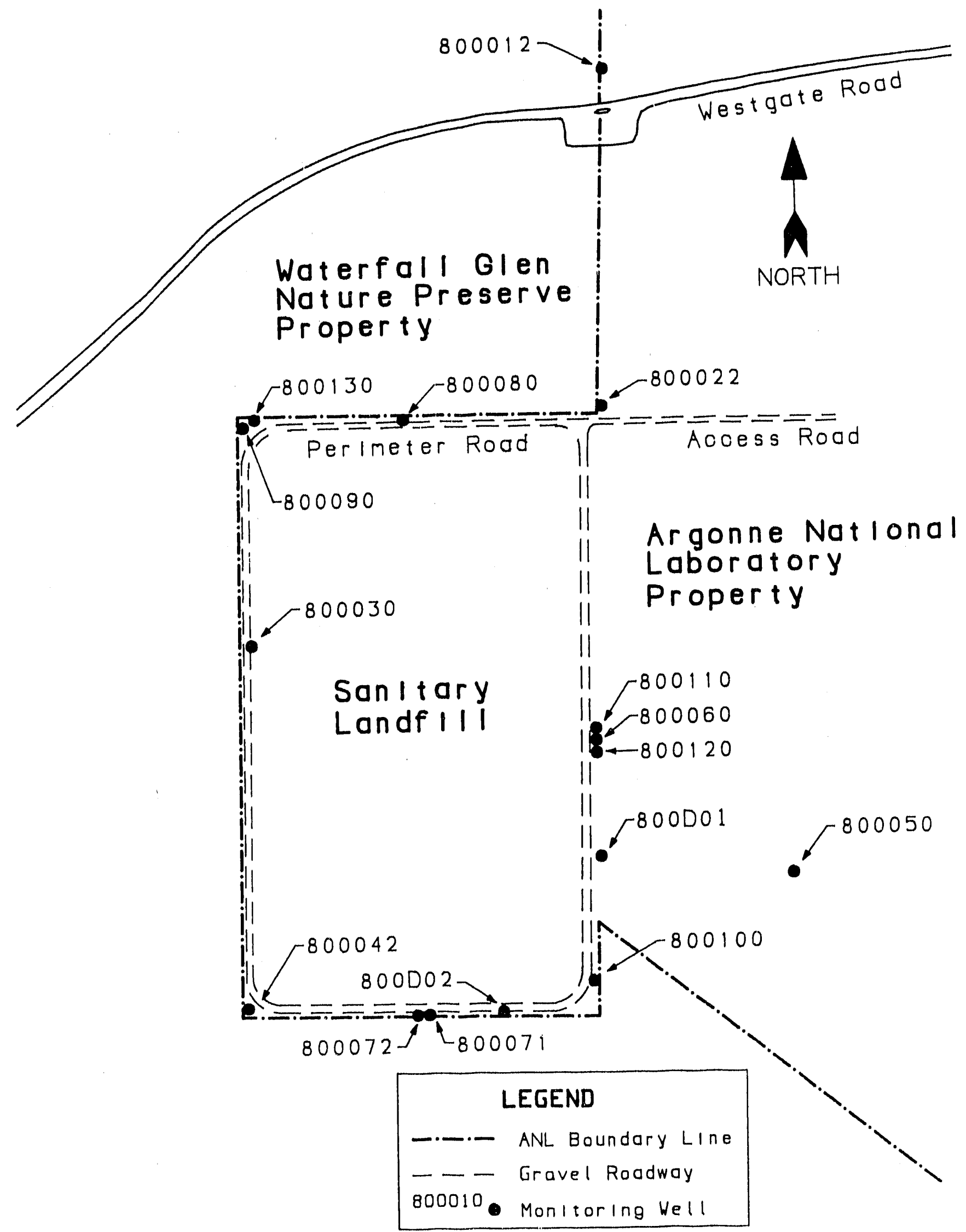

Figure 6.5 Monitoring Well Locations for Landfill in the 800 Area 
at a depth of $24 \mathrm{~m}(80 \mathrm{ft})$, exhibit very different characteristics. We11 800130 has an abundant supply of water [casing volume of about $100 \mathrm{~L}$ (27 ga1)] while well 800120 is usually dry. It is not known if there is a water layer at this depth or if well 800130 is in a local body of water. The dolomite wells are at a depth of about $45 \mathrm{~m}(140 \mathrm{ft})$, and both have an abundant supply of water.

\subsubsection{Results of Analyses}

A description of each we11, a listing of field parameters measured during sample collection, and the results of chemical and radiological analysis of samples from the wells in the 800 Area are contained in Tables 6.16 to 6.28. Al1 radiological and inorganic analysis results are shown in these tables. The analysis methods used for organic compounds will identify and quantify all the compounds contained in the CLP Target Compound List shown in Table 6.3. However, the vast majority of these compounds were not detected in the samples. To simplify the format of these tables, these negative results are not included. Only those constituents which were present in amounts great enough to quantify are shown. The detection limits for the organic compounds listed were typically 5 to $10 \mu \mathrm{g} / \mathrm{L}$.

\section{Inorganic Constituents}

With the exception of three wells, the inorganic constituents were typical of groundwater in this region. Significant levels of arsenic were detected in wells 800030, 800090, and 800130 and a lesser amount was detected in 800100 . In previous years arsenic had been consistently found in 800030 . The presence of arsenic in the other wells was noted in the previous report. The levels of most of the inorganic constituents in wells 800030 and 800090 are greater than the concentrations in the other we11s. of particular note are chromium, copper, and lead. The chromium in 800030 and 800090 averaged about $40 \mu \mathrm{g} / \mathrm{L}$ as compared to a background of about 4 $\mu \mathrm{g} / \mathrm{L}$. The copper in these wells averaged 400 and $100 \mu \mathrm{g} / \mathrm{L}$, respectively, as compared to $<10 \mu \mathrm{g} / \mathrm{L}$ background. The lead averaged 100 and $60 \mu \mathrm{g} / \mathrm{L}$, respectively, as compared to a background of less than $10 \mu \mathrm{g} / \mathrm{L}$. The chloride concentrations are elevated in wells 800012,800042 , and 800060 where the 
TABLE 6.16

Groundwater Monitoring Results, Sanitary Landfill Perimeter We11 \#800012, 1990

\begin{tabular}{|c|c|c|c|c|c|}
\hline \multirow[b]{2}{*}{ Constituent } & \multirow[b]{2}{*}{ Units } & \multirow[b]{2}{*}{$03 / 30 / 90$} & \multicolumn{2}{|c|}{$\begin{array}{l}\text { Well Point Elevation } \\
\text { Ground Surface Elevation } \\
\text { Casing Material: }\end{array}$} & \multirow{2}{*}{$\begin{array}{l}\mathrm{m}(\mathrm{MSL}) \\
219.91 \\
227.69 \\
\mathrm{PVC} \\
12 / 06 / 90\end{array}$} \\
\hline & & & $06 / 12 / 90$ & $09 / 21 / 90$ & \\
\hline $\begin{array}{l}\text { Water Elevation } \\
\text { Temperature } \\
\mathrm{pH} \\
\text { Redox } \\
\text { Conductivity }\end{array}$ & $\begin{array}{c}{ }_{{ }^{\circ} \mathrm{C}} \\
\mathrm{pH} \\
\mathrm{mV} \\
\mu \mathrm{mhos} / \mathrm{cm}\end{array}$ & $\begin{array}{c}226.40 \\
10.2 \\
7.10 \\
-- \\
1290^{-}\end{array}$ & $\begin{array}{c}226.07 \\
12.0 \\
6.37 \\
55 \\
2510\end{array}$ & $\begin{array}{c}225.47 \\
14.1 \\
7.09 \\
-266 \\
2250\end{array}$ & $\begin{array}{c}227.32 \\
12.6 \\
7.14 \\
2 \\
1915\end{array}$ \\
\hline $\begin{array}{l}\text { Arsenic } \\
\text { Barium } \\
\text { Berylium } \\
\text { Cadmium } \\
\text { Chloride } \\
\text { Chromium } \\
\text { Cobalt } \\
\text { Copper } \\
\text { Iron } \\
\text { Lead } \\
\text { Manganese } \\
\text { Mercury } \\
\text { Nickel } \\
\text { Selenium } \\
\text { Silver } \\
\text { Thallium } \\
\text { Vanadium } \\
\text { Zinc } \\
\text { Hydrogen-3 } \\
\text { Bis(2-Ethylnexy1)Phthala }\end{array}$ & $\begin{array}{l}\mathrm{mg} / \mathrm{L} \\
\mathrm{mg} / \mathrm{L} \\
\mu \mathrm{g} / \mathrm{L} \\
\mathrm{mg} / \mathrm{L} \\
\mathrm{mg} / \mathrm{L} \\
\mathrm{mg} / \mathrm{L} \\
\mathrm{mg} / \mathrm{L} \\
\mathrm{mg} / \mathrm{L} \\
\mathrm{mg} / \mathrm{L} \\
\mathrm{mg} / \mathrm{L} \\
\mathrm{mg} / \mathrm{L} \\
\mu \mathrm{g} / \mathrm{L} \\
\mathrm{mg} / \mathrm{L} \\
\mathrm{mg} / \mathrm{L} \\
\mathrm{mg} / \mathrm{L} \\
\mathrm{mg} / \mathrm{L} \\
\mathrm{mg} / \mathrm{L} \\
\mathrm{mg} / \mathrm{L} \\
\mathrm{nCi} / \mathrm{L} \\
\mu \mathrm{g} / \mathrm{L}\end{array}$ & $\begin{aligned} &< 0.0025 \\
& 0.2264 \\
&< 0.2 \\
& 0.0008 \\
& 818 \\
&< 0.004 \\
&< 0.03 \\
&< 0.01 \\
& 0.7 \\
& 0.005 \\
& 0.236 \\
&< 0.1 \\
&< 0.025 \\
&< 0.005 \\
&< 0.0005 \\
&< 0.01 \\
&< 0.015 \\
&< 0.01 \\
& 0.146 \\
&-\end{aligned}$ & $\begin{aligned} &< 0.0025 \\
& 0.2141 \\
&< 0.2 \\
& 0.0011 \\
& 856 \\
&< 0.004 \\
&< 0.03 \\
& 0.01 \\
& 0.8 \\
&< 0.002 \\
& 0.532 \\
&< 0.1 \\
&< 0.025 \\
&< 0.0005 \\
&< 0.01 \\
&< 0.015 \\
&< 0.01 \\
& 0.135 \\
&-\end{aligned}$ & $\begin{aligned} &< 0.0025 \\
& 0.1603 \\
&< 0.2 \\
& 0.0005 \\
& 609 \\
& 0.007 \\
&< 0.03 \\
&< 0.01 \\
& 0.7 \\
&< 0.002 \\
& 0.384 \\
&< 0.1 \\
& 0.034 \\
&- \\
&< 0.0005 \\
&< 0.01 \\
&< 0.015 \\
&< 0.01 \\
&< 0.100 \\
&-\end{aligned}$ & $\begin{aligned} & 0.0027 \\
& 0.1210 \\
&< 5.0 \\
&< 0.0050 \\
& 569 \\
& 0.014 \\
&< 0.05 \\
&< 0.01 \\
& 4.2 \\
& 0.005 \\
& 0.511 \\
&< 0.1 \\
&< 0.040 \\
&< 0.0100 \\
&< 0.01 \\
& 0.054 \\
& 0.02 \\
&-\end{aligned}$ \\
\hline
\end{tabular}


TABLE 6.17

Groundwater Monitoring Results, Santtary Landf 111 Perimeter We11 \#800022, 1990

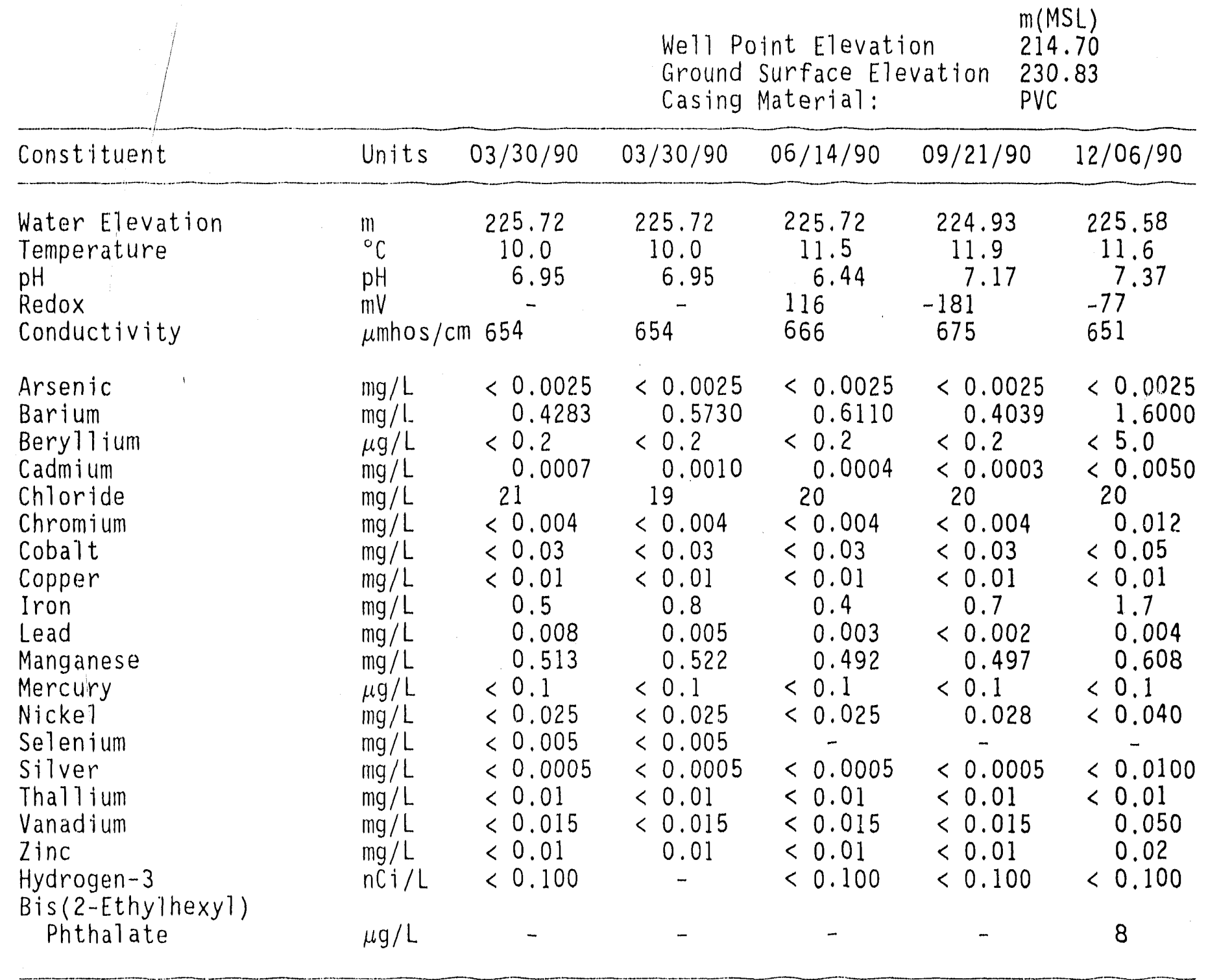


TABLE 6.18

Groundwater Monitoring Results, Sanitary Landfi11 Perimeter We11 \#800030, 1990 $\begin{array}{ll} & m(M S L) \\ \text { Well Point Elevation } & 217.51 \\ \text { Ground Surface Elevation } & 226.77 \\ \text { Casing Material: } & \text { PVC }\end{array}$

\begin{tabular}{|c|c|c|c|c|c|c|}
\hline Constituent & Units & $03 / 28 / 90$ & $06 / 12 / 90$ & $09 / 20 / 90$ & $12 / 06 / 90$ & $12 / 06 / 90$ \\
\hline $\begin{array}{l}\text { Water Elevation } \\
\text { Temperature } \\
\mathrm{pH} \\
\text { Redox } \\
\text { Conductivity }\end{array}$ & $\begin{array}{l}{ }_{\mathrm{m}}^{\mathrm{o}} \\
{ }^{\mathrm{C}} \\
\mathrm{pH} \\
\mathrm{mV} \\
\mu \text { mhos } / \mathrm{cm}\end{array}$ & $\begin{array}{c}223.78 \\
10.2 \\
6.54 \\
- \\
980\end{array}$ & $\begin{array}{l}224.18 \\
11.7 \\
6.24 \\
-36 \\
929\end{array}$ & $\begin{array}{c}223.69 \\
12.3 \\
6.72 \\
-298 \\
910\end{array}$ & $\begin{array}{l}223.97 \\
11.2 \\
6.65 \\
-17 \\
914\end{array}$ & $\begin{array}{l}223.97 \\
11.2 \\
6.65 \\
-17 \\
914\end{array}$ \\
\hline $\begin{array}{l}\text { Arsenic } \\
\text { Barium } \\
\text { Beryllium } \\
\text { Cadmium } \\
\text { Chloride } \\
\text { Chromium } \\
\text { Cobalt } \\
\text { Copper } \\
\text { Iron } \\
\text { Lead } \\
\text { Manganese } \\
\text { Mercury } \\
\text { Nickel } \\
\text { Silver } \\
\text { Thallium } \\
\text { Vanadium } \\
\text { Zinc } \\
\text { Hydrogen-3 } \\
\text { Bis(2-Ethylhexyl) } \\
\text { Phthalate }\end{array}$ & $\begin{array}{l}\mathrm{mg} / \mathrm{L} \\
\mathrm{mg} / \mathrm{L} \\
\mu \mathrm{g} / \mathrm{L} \\
\mathrm{mg} / \mathrm{L} \\
\mathrm{mg} / \mathrm{L} \\
\mathrm{mg} / \mathrm{L} \\
\mathrm{mg} / \mathrm{L} \\
\mathrm{mg} / \mathrm{L} \\
\mathrm{mg} / \mathrm{L} \\
\mathrm{mg} / \mathrm{L} \\
\mathrm{mg} / \mathrm{L} \\
\mu \mathrm{g} / \mathrm{L} \\
\mathrm{mg} / \mathrm{L} \\
\mathrm{mg} / \mathrm{L} \\
\mathrm{mg} / \mathrm{L} \\
\mathrm{mg} / \mathrm{L} \\
\mathrm{mg} / \mathrm{L} \\
\mathrm{nCi} / \mathrm{L} \\
\mu \mathrm{g} / \mathrm{L}\end{array}$ & $\begin{array}{c}0.0365 \\
1.5280 \\
9.2 \\
0.0103 \\
9 \\
0.077 \\
0.45 \\
1.23 \\
928.7 \\
0.443 \\
16.860 \\
0.1 \\
1.030 \\
0.0006 \\
<0.01 \\
0.113 \\
2.41 \\
<0.100 \\
\\
-\end{array}$ & $\begin{aligned} & 0.0031 \\
& 0.3160 \\
< & 0.2 \\
& 0.0012 \\
& 2 \\
& 0.004 \\
< & 0.03 \\
& 0.01 \\
& 5.5 \\
& 0.005 \\
& 0.065 \\
< & 0.1 \\
< & 0.025 \\
< & 0.0005 \\
< & 0.01 \\
< & 0.015 \\
< & 0.01 \\
< & 0.100\end{aligned}$ & 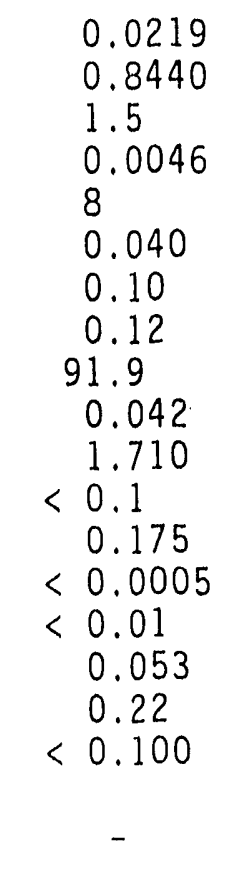 & $\begin{aligned} & 0.0094 \\
& 0.3150 \\
< & 5.0 \\
< & 0.0050 \\
& 5 \\
& 0.034 \\
< & 0.05 \\
< & 0.01 \\
& 22.5 \\
& 0.016 \\
& 0.642 \\
< & 0.1 \\
< & 0.040 \\
< & 0.0100 \\
< & 0.01 \\
& 0.069 \\
& 0.06 \\
< & 0.100 \\
& 19\end{aligned}$ & $\begin{aligned} & 0.0097 \\
& 0.3190 \\
&< 5.0 \\
& 0.0059 \\
& 5 \\
& 0.039 \\
&< 0.05 \\
& 0.01 \\
& 26.5 \\
& 0.015 \\
& 0.766 \\
&< 0.1 \\
& 0.040 \\
&< 0.0100 \\
&< 0.01 \\
& 0.071 \\
& 0.07 \\
&- \\
& 5\end{aligned}$ \\
\hline
\end{tabular}


TAPLE 6.19

Groundwater Monitoring Results, Sanitary Landfi11 Perimeter We11 \#800042, 1990

\begin{tabular}{|c|c|c|c|c|}
\hline \multirow[b]{2}{*}{ Constituent } & \multirow[b]{2}{*}{ Units } & \multicolumn{2}{|c|}{$\begin{array}{l}\text { We } 11 \text { Point Elevation } \\
\text { Ground Surface Elevation } \\
\text { Casing Material: }\end{array}$} & \multirow{2}{*}{$\begin{array}{l}m(M S L) \\
219.48 \\
227.23 \\
\text { PVC } \\
09 / 27 / 90\end{array}$} \\
\hline & & $04 / 03 / 90$ & $06 / 19 / 90$ & \\
\hline $\begin{array}{l}\text { Water Elevation } \\
\text { Temperature } \\
\mathrm{pH} \\
\text { Redox } \\
\text { Conductivity }\end{array}$ & $\begin{array}{l}{ }^{\mathrm{m}} \\
{ }^{\circ} \mathrm{C} \\
\mathrm{pH} \\
\mathrm{mV} \\
\mu \mathrm{mhos} / \mathrm{cm}\end{array}$ & $\begin{array}{c}224.64 \\
11.5 \\
6.94 \\
- \\
-\end{array}$ & $\begin{array}{c}224.76 \\
11.0 \\
6.58 \\
14 \\
1503\end{array}$ & $\begin{array}{c}224.41 \\
12.5 \\
6.85 \\
-296 \\
1160\end{array}$ \\
\hline $\begin{array}{l}\text { Arsenic } \\
\text { Barium } \\
\text { Berylium } \\
\text { Cadmium } \\
\text { Chloride } \\
\text { Chromium } \\
\text { Cobalt } \\
\text { Copper } \\
\text { Iron } \\
\text { Lead } \\
\text { Manganese } \\
\text { Mercury } \\
\text { Nickel } \\
\text { Selenium } \\
\text { Silver } \\
\text { Thallium } \\
\text { Vanadium } \\
\text { Zinc } \\
\text { Hydrogen-3 }\end{array}$ & $\begin{array}{l}\mathrm{mg} / \mathrm{L} \\
\mathrm{mg} / \mathrm{L} \\
\mu \mathrm{g} / \mathrm{L} \\
\mathrm{mg} / \mathrm{L} \\
\mathrm{mg} / \mathrm{L} \\
\mathrm{mg} / \mathrm{L} \\
\mathrm{mg} / \mathrm{L} \\
\mathrm{mg} / \mathrm{L} \\
\mathrm{mg} / \mathrm{L} \\
\mathrm{mg} / \mathrm{L} \\
\mathrm{mg} / \mathrm{L} \\
\mu \mathrm{g} / \mathrm{L} \\
\mathrm{mg} / \mathrm{L} \\
\mathrm{mg} / \mathrm{L} \\
\mathrm{mg} / \mathrm{L} \\
\mathrm{mg} / \mathrm{L} \\
\mathrm{mg} / \mathrm{L} \\
\mathrm{mg} / \mathrm{L} \\
\mathrm{nCi} / \mathrm{L}\end{array}$ & $\begin{aligned}< & 0.0025 \\
& 0.7130 \\
< & 0.2 \\
& 0.0010 \\
236 & \\
< & 0.004 \\
< & 0.03 \\
< & 0.01 \\
& 3.9 \\
& 0.009 \\
& 0.311 \\
< & 0.1 \\
< & 0.025 \\
< & 0.005 \\
< & 0.0005 \\
< & 0.01 \\
< & 0.015 \\
& 0.02 \\
< & 0.100\end{aligned}$ & $\begin{aligned} &< 0.0025 \\
& 0.4908 \\
&< 0.2 \\
& 0.0006 \\
& 216 \\
&< 0.004 \\
&< 0.03 \\
& 0.01 \\
& 1.1 \\
& 0.007 \\
& 0.169 \\
&< 0.1 \\
&< 0.025 \\
&<- \\
&< 0.0005 \\
&< 0.01 \\
&< 0.015 \\
&< 0.01 \\
&< 0.100\end{aligned}$ & $\begin{aligned} & 0.0039 \\
& 0.0501 \\
< & 0.2 \\
& 0.0009 \\
160 & \\
& 0.009 \\
& 0.04 \\
& 0.04 \\
13.2 & \\
& 0.010 \\
& 0.456 \\
< & 0.1 \\
& 0.065 \\
< & - \\
< & 0.0005 \\
< & 0.01 \\
< & 0.015 \\
& 0.06 \\
< & 0.100\end{aligned}$ \\
\hline
\end{tabular}


TABLE 6.20

Groundwater Monitoring Results,

Sanitary Landfill Perimeter Wel1 \#800050, 1990

$\begin{array}{ll}\text { Well Point Elevation } & \mathrm{m}(\mathrm{MSL}) \\ \text { Ground Surface Elevation } & 202.08 \\ \text { Casing Material: } & \text { PVC }\end{array}$

\begin{tabular}{llc}
\hline Constituent & Units & $06 / 05 / 90$ \\
\hline Water Elevation & $\mathrm{m}$ & 217.27 \\
Temperature & ${ }^{\circ} \mathrm{C}$ & 9.4 \\
$\mathrm{pH}$ & $\mathrm{pH}$ & 7.69 \\
Redox & $\mathrm{mV}$ & -54 \\
Conductivity & $\mu \mathrm{mhos} / \mathrm{cm}$ & 416 \\
Arsenic & $\mathrm{mg} / \mathrm{L}$ & 0.0070 \\
Barium & $\mathrm{mg} / \mathrm{L}$ & 0.1520 \\
Beryllium & $\mu \mathrm{g} / \mathrm{L}$ & $<5.0$ \\
Cadmium & $\mathrm{mg} / \mathrm{L}$ & 0.0055 \\
Chloride & $\mathrm{mg} / \mathrm{L}$ & 12 \\
Chromium & $\mathrm{mg} / \mathrm{L}$ & 0.0700 \\
Cobalt & $\mathrm{mg} / \mathrm{L}$ & $<0.5$ \\
Iron & $\mathrm{mg} / \mathrm{L}$ & 46.7 \\
Lead & $\mathrm{mg} / \mathrm{L}$ & 0.049 \\
Manganese & $\mathrm{mg} / \mathrm{L}$ & 1.180 \\
Mercury & $\mathrm{hg} / \mathrm{L}$ & $<0.1$ \\
Nickel & $\mathrm{mg} / \mathrm{L}$ & 0.056 \\
Silver & $\mathrm{mg} / \mathrm{L}$ & 0.0100 \\
Thallium & $\mathrm{mg} / \mathrm{L}$ & $<0.01$ \\
Vanadium & $\mathrm{mg} / \mathrm{L}$ & 0.085 \\
Zinc & $\mathrm{mg} / \mathrm{L}$ & 0.16 \\
Hydrogen-3 & $\mathrm{nCi} / \mathrm{L}$ & 0.123 \\
Bis-(2-Ethyhexyl)Phthalate & $\mu \mathrm{g} / \mathrm{L}$ & 14 \\
& & \\
\hline
\end{tabular}


TABLE 6.21

Groundwater Monitoring Results, Sanitary Landfill Perimeter We11 \#800060, 1990

$\begin{array}{ll}\text { We11 Point Elevation } & m(M S L) \\ \text { Ground Surface Elevation } & 220.89 \\ \text { Casing Material: } & \text { PVC }\end{array}$

\begin{tabular}{|c|c|c|c|c|c|}
\hline Constituent & Units & $03 / 30 / 90$ & $06 / 12 / 90$ & $09 / 21 / 90$ & $12 / 06 / 90$ \\
\hline $\begin{array}{l}\text { Water Elevation } \\
\text { Temperature } \\
\text { pH } \\
\text { Redox } \\
\text { Conductivity }\end{array}$ & $\begin{array}{c}{ }^{\mathrm{m}} \\
{ }^{\circ} \mathrm{C} \\
\mathrm{pH} \\
\mathrm{mV} \\
\mu \mathrm{mhos} / \mathrm{cm}\end{array}$ & $\begin{array}{c}215.25 \\
11.0 \\
6.56 \\
1315^{-}\end{array}$ & $\begin{array}{c}215.27 \\
12.5 \\
6.02 \\
-9 \\
1380\end{array}$ & $\begin{array}{c}215.07 \\
13.6 \\
6.55 \\
-280 \\
1499\end{array}$ & $\begin{array}{c}215.17 \\
10.0 \\
6.35 \\
-41 \\
1322\end{array}$ \\
\hline $\begin{array}{l}\text { Arsenic } \\
\text { Barium } \\
\text { Beryllium } \\
\text { Cadmium } \\
\text { Chloride } \\
\text { Chromium } \\
\text { Cobalt } \\
\text { Copper } \\
\text { Iron } \\
\text { Lead } \\
\text { Manganese } \\
\text { Mercury } \\
\text { Nickel } \\
\text { Selenium } \\
\text { Silver } \\
\text { Thallium } \\
\text { Vanadium } \\
\text { Zinc } \\
\text { Hydrogen-3 } \\
\text { Chrysene }\end{array}$ & $\begin{array}{l}\mathrm{mg} / \mathrm{L} \\
\mathrm{mg} / \mathrm{L} \\
\mu \mathrm{g} / \mathrm{L} \\
\mathrm{mg} / \mathrm{L} \\
\mathrm{mg} / \mathrm{L} \\
\mathrm{mg} / \mathrm{L} \\
\mathrm{mg} / \mathrm{L} \\
\mathrm{mg} / \mathrm{L} \\
\mathrm{mg} / \mathrm{L} \\
\mathrm{mg} / \mathrm{L} \\
\mathrm{mg} / \mathrm{L} \\
\mu \mathrm{g} / \mathrm{L} \\
\mathrm{mg} / \mathrm{L} \\
\mathrm{mg} / \mathrm{L} \\
\mathrm{mg} / \mathrm{L} \\
\mathrm{mg} / \mathrm{L} \\
\mathrm{mg} / \mathrm{L} \\
\mathrm{mg} / \mathrm{L} \\
\mathrm{nC} i / \mathrm{L} \\
\mu \mathrm{g} / \mathrm{L}\end{array}$ & $\begin{aligned}< & 0.0025 \\
& 0.2033 \\
< & 0.2 \\
& 0.0007 \\
200 & < \\
< & 0.004 \\
< & 0.03 \\
< & 0.01 \\
& 2.8 \\
& 0.004 \\
& 0.971 \\
< & 0.1 \\
< & 0.025 \\
< & 0.005 \\
< & 0.0005 \\
< & 0.01 \\
< & 0.015 \\
& 0.01 \\
& 0.685 \\
& -\end{aligned}$ & $\begin{array}{rl}< & 0.0025 \\
& 0.1856 \\
< & 0.2 \\
& 0.0006 \\
2 & 12 \\
< & 0.004 \\
< & 0.03 \\
< & 0.01 \\
& 5.6 \\
& 0.004 \\
& 0.952 \\
< & 0.1 \\
< & 0.025 \\
< & - \\
< & 0.0005 \\
< & 0.01 \\
< & 0.015 \\
< & 0.01 \\
& 0.633 \\
& -\end{array}$ & $\begin{aligned} & 0.0034 \\
& 0.1973 \\
&< 0.2 \\
& 0.0003 \\
& 237 \\
&< 0.004 \\
&< 0.03 \\
&< 0.01 \\
& 21.4 \\
&< 0.002 \\
& 0.884 \\
&< 0.1 \\
& 0.054 \\
&- \\
&< 0.0005 \\
&< 0.01 \\
&< 0.015 \\
& 0.02 \\
& 0.594 \\
&-\end{aligned}$ & $\begin{aligned} &< 0.0025 \\
& 0.1580 \\
&< 5.0 \\
&< 0.0050 \\
& 244 \\
&< 0.010 \\
&< 0.05 \\
&< 0.01 \\
& 3.1 \\
&< 0.002 \\
& 0.853 \\
&< 0.1 \\
&< 0.040 \\
&<- \\
&< 0.0100 \\
&< 0.01 \\
&< 0.050 \\
&< 0.01 \\
& 0.785 \\
& 8\end{aligned}$ \\
\hline
\end{tabular}


TABLE 6.22

Groundwater Monitoring Results, Sanitary Landfill Perimeter We11 \#800071, 1990

\begin{tabular}{|c|c|c|c|c|c|c|}
\hline \multirow[b]{2}{*}{ Constituent } & \multirow[b]{2}{*}{ Units } & \multirow[b]{2}{*}{$03 / 30 / 90$} & \multicolumn{3}{|c|}{$\begin{array}{l}\text { Well Point Elevation } \\
\text { Ground Surface Elevation } \\
\text { Casing Material: }\end{array}$} & \multirow{2}{*}{$\begin{array}{l}m(M S L) \\
216.51 \\
227.81 \\
\text { PVC } \\
12 / 06 / 90\end{array}$} \\
\hline & & & $06 / 12 / 90$ & $09 / 21 / 90$ & $09 / 21 / 90$ & \\
\hline $\begin{array}{l}\text { Water Elevation } \\
\text { Temperature } \\
\mathrm{pH} \\
\text { Redox } \\
\text { Conductivity }\end{array}$ & $\begin{array}{c}{ }^{\mathrm{m}} \\
{ }^{\circ} \mathrm{C} \\
\mathrm{pH} \\
\mathrm{mV} \\
\mu \mathrm{mhos} / \mathrm{cm}\end{array}$ & $\begin{array}{c}226.52 \\
8.2 \\
6.71 \\
- \\
852\end{array}$ & $\begin{array}{l}224.28 \\
10.5 \\
6.39 \\
-37 \\
726\end{array}$ & $\begin{array}{c}223.44 \\
11.4 \\
6.98 \\
-183 \\
824\end{array}$ & $\begin{array}{c}223.44 \\
11.4 \\
6.98 \\
-183 \\
824\end{array}$ & $\begin{array}{l}222.99 \\
11.1 \\
6.77 \\
-208 \\
866\end{array}$ \\
\hline $\begin{array}{l}\text { Arsenic } \\
\text { Barium } \\
\text { Beryllium } \\
\text { Cadmium } \\
\text { Chloride } \\
\text { Chromium } \\
\text { Cobalt } \\
\text { Copper } \\
\text { Iron } \\
\text { Lead } \\
\text { Manganese } \\
\text { Mercury } \\
\text { Nickel } \\
\text { Selenium } \\
\text { Silver } \\
\text { Thallium } \\
\text { Vanadium } \\
\text { Zinc } \\
\text { Hydrogen-3 } \\
\text { Bis(2-Ethylhexyl) } \\
\text { Phthalate }\end{array}$ & $\begin{array}{l}\mathrm{mg} / \mathrm{L} \\
\mathrm{mg} / \mathrm{L} \\
\mu \mathrm{g} / \mathrm{L} \\
\mathrm{mg} / \mathrm{L} \\
\mathrm{mg} / \mathrm{L} \\
\mathrm{mg} / \mathrm{L} \\
\mathrm{mg} / \mathrm{L} \\
\mathrm{mg} / \mathrm{L} \\
\mathrm{mg} / \mathrm{L} \\
\mathrm{mg} / \mathrm{L} \\
\mathrm{mg} / \mathrm{L} \\
\mu \mathrm{g} / \mathrm{L} \\
\mathrm{mg} / \mathrm{L} \\
\mathrm{mg} / \mathrm{L} \\
\mathrm{mg} / \mathrm{L} \\
\mathrm{mg} / \mathrm{L} \\
\mathrm{mg} / \mathrm{L} \\
\mathrm{mg} / \mathrm{L} \\
\mathrm{nC} \mathrm{i} / \mathrm{L} \\
\mu \mathrm{g} / \mathrm{L} \\
\mu \mathrm{g} / \mathrm{L}\end{array}$ & $\begin{aligned}< & 0.0025 \\
& 0.1777 \\
< & 0.2 \\
& 0.0022 \\
& 34 \\
< & 0.004 \\
< & 0.03 \\
< & 0.01 \\
& 2.3 \\
& 0.005 \\
& 0.258 \\
& 0.1 \\
< & 0.025 \\
< & 0.005 \\
< & 0.0005 \\
< & 0.01 \\
< & 0.015 \\
& 0.01 \\
& 0.528\end{aligned}$ & $\begin{aligned}< & 0.0025 \\
& 0.1096 \\
< & 0.2 \\
& 0.0006 \\
& 28 \\
< & 0.004 \\
< & 0.03 \\
< & 0.01 \\
& 1.0 \\
& 0.004 \\
& 0.336 \\
< & 0.1 \\
< & 0.025 \\
& - \\
< & 0.0005 \\
< & 0.01 \\
< & 0.015 \\
< & 0.01 \\
& 0.175\end{aligned}$ & $\begin{aligned}< & 0.0025 \\
& 0.0985 \\
< & 0.2 \\
& 0.0014 \\
34 & \\
& 0.004 \\
< & 0.03 \\
& 0.01 \\
& 1.7 \\
& 0.002 \\
& 0.269 \\
< & 0.1 \\
& 0.030 \\
& - \\
< & 0.0005 \\
< & 0.01 \\
< & 0.015 \\
& 0.02 \\
& 0.392\end{aligned}$ & $\begin{aligned}< & 0.0025 \\
& 0.1178 \\
< & 0.2 \\
< & 0.0003 \\
& 33 \\
< & 0.004 \\
< & 0.03 \\
< & 0.01 \\
< & 1.3 \\
< & 0.002 \\
& 0.257 \\
< & 0.1 \\
& 0.026 \\
& - \\
< & 0.0005 \\
< & 0.01 \\
< & 0.015 \\
& 0.01 \\
& 0.392\end{aligned}$ & $\begin{aligned}< & 0.0025 \\
& 0.1050 \\
< & 5.0 \\
< & 0.0050 \\
& 46 \\
& 0.011 \\
< & 0.05 \\
< & 0.01 \\
& 3.6 \\
& 0.004 \\
& 0.315 \\
< & 0.1 \\
< & 0.040 \\
& - \\
< & 0.0100 \\
< & 0.01 \\
& 0.058 \\
& 0.01 \\
& -\end{aligned}$ \\
\hline Phthalate & $\mu \mathrm{g} / \mathrm{L}$ & - & - & - & - & 9 \\
\hline
\end{tabular}


TABLE 6.23

Groundwater Monitoring Results, Sanitary Landfi11 Perimeter We11 \#800080, 1990

$\begin{array}{ll}\text { We11 Point Elevation } & m(M S L) \\ \text { Ground Surface Elevation } & 218.71 \\ \text { Casing Material: } & \text { PVC }\end{array}$

\begin{tabular}{|c|c|c|c|c|c|}
\hline Constituent & Units & $03 / 30 / 90$ & $06 / 14 / 90$ & $09 / 27 / 90$ & $12 / 06 / 90$ \\
\hline $\begin{array}{l}\text { Water Elevation } \\
\text { Temperature } \\
\text { pH } \\
\text { Redox } \\
\text { Conductivity }\end{array}$ & $\begin{array}{c}{ }^{\mathrm{m}} \\
{ }^{\circ} \mathrm{C} \\
\mathrm{pH} \\
\mathrm{mV} \\
\text { emhos } / \mathrm{cm} .\end{array}$ & $\begin{array}{c}229.34 \\
7.6 \\
6.74 \\
- \\
1075\end{array}$ & $\begin{array}{c}228.15 \\
12.1 \\
6.18 \\
139 \\
1249\end{array}$ & $\begin{array}{c}224.97 \\
14.7 \\
6.87 \\
-30 \\
1165\end{array}$ & $\begin{array}{c}229.03 \\
11.9 \\
6.70 \\
-10 \\
1220\end{array}$ \\
\hline $\begin{array}{l}\text { Arsenic } \\
\text { Barium } \\
\text { Beryllium } \\
\text { Cadmium } \\
\text { Chloride } \\
\text { Chromium } \\
\text { Cobalt } \\
\text { Copper } \\
\text { Iron } \\
\text { Lead } \\
\text { Manganese } \\
\text { Mercury } \\
\text { Nickel } \\
\text { Selenium } \\
\text { Silver } \\
\text { Thallium } \\
\text { Vanadium } \\
\text { Zinc } \\
\text { Hydrogen-3 } \\
\text { Bis(2-Ethylhexyl)Phthalate }\end{array}$ & $\begin{array}{l}\mathrm{mg} / \mathrm{L} \\
\mathrm{mg} / \mathrm{L} \\
\mu \mathrm{g} / \mathrm{L} \\
\mathrm{mg} / \mathrm{L} \\
\mathrm{mg} / \mathrm{L} \\
\mathrm{mg} / \mathrm{L} \\
\mathrm{mg} / \mathrm{L} \\
\mathrm{mg} / \mathrm{L} \\
\mathrm{mg} / \mathrm{L} \\
\mathrm{mg} / \mathrm{L} \\
\mathrm{mg} / \mathrm{L} \\
\mu \mathrm{g} / \mathrm{L} \\
\mathrm{mg} / \mathrm{L} \\
\mathrm{mg} / \mathrm{L} \\
\mathrm{mg} / \mathrm{L} \\
\mathrm{mg} / \mathrm{L} \\
\mathrm{mg} / \mathrm{L} \\
\mathrm{mg} / \mathrm{L} \\
\mathrm{nCi} / \mathrm{L} \\
\mu \mathrm{g} / \mathrm{L}\end{array}$ & $\begin{aligned} &< 0.0025 \\
& 0.0959 \\
&< 0.2 \\
& 0.0006 \\
& 102 \\
&< 0.004 \\
&< 0.03 \\
&< 0.01 \\
& 0.2 \\
& 0.004 \\
& 0.235 \\
&< 0.1 \\
&< 0.025 \\
&< 0.005 \\
&< 0.0005 \\
&< 0.01 \\
&< 0.015 \\
&< 0.01 \\
& 0.246 \\
&-\end{aligned}$ & $\begin{aligned} &< 0.0025 \\
& 0.0739 \\
&< 0.2 \\
& 0.0010 \\
& 123 \\
&< \\
&<0.004 \\
&<0.03 \\
& 0.01 \\
& 0.4 \\
& 0.002 \\
& 0.259 \\
&< 0.1 \\
&< 0.025 \\
&- \\
&< 0.0005 \\
&< 0.01 \\
&< 0.015 \\
& 0.01 \\
& 0.180 \\
&-\end{aligned}$ & $\begin{aligned} & 0.0142 \\
& 0.1079< \\
&< 0.2 \\
& 0.0042 \\
& 97 \\
& 0.017 \\
& 0.06 \\
& 0.05 \\
& 24.7 \\
& 0.022 \\
& 0.939 \\
&<0.1 \\
& 0.086 \\
&<0.0005 \\
&<0.01 \\
& 0.015 \\
& 0.11 \\
&<0.100 \\
&-\end{aligned}$ & $\begin{aligned} &< 0.0025 \\
& 0.0630 \\
&< 5.0 \\
&< 0.0050 \\
& 117 \\
&<0.010 \\
&<0.05 \\
&<0.01 \\
& 0.5 \\
&<0.002 \\
& 0.331 \\
&<0.1 \\
&<0.040 \\
&<0.0100 \\
&<0.01 \\
& 0.054 \\
& 0.01 \\
& 0.117 \\
& 190\end{aligned}$ \\
\hline
\end{tabular}


TABLE 6.24

Groundwater Monitoring Results, Santtary Landfill Perimeter Well \#800090, 1990

\begin{tabular}{|c|c|c|c|c|c|}
\hline \multirow[b]{2}{*}{ Constituent } & \multirow[b]{2}{*}{ Units } & \multirow[b]{2}{*}{$03 / 28 / 90$} & \multicolumn{2}{|c|}{$\begin{array}{l}\text { Wels Point Elevation } \\
\text { Ground Surface Elevation } \\
\text { Casing Material: }\end{array}$} & \multirow{2}{*}{$\begin{array}{l}m(M S L) \\
223.79 \\
230.00 \\
\text { PVC } \\
12 / 05 / 90\end{array}$} \\
\hline & & & $06 / 12 / 90$ & $09 / 18 / 90$ & \\
\hline $\begin{array}{l}\text { Water Elevation } \\
\text { Temperature } \\
\text { pH } \\
\text { Redox } \\
\text { Conduct ivity }\end{array}$ & $\begin{array}{c}{ }^{\mathrm{m}} \\
{ }^{\circ} \mathrm{C} \\
\mathrm{pH} \\
\mathrm{mV} \\
\text { emhos } / \mathrm{cm}\end{array}$ & $\begin{array}{c}228.08 \\
10.5 \\
6.46 \\
- \\
1178^{-}\end{array}$ & $\begin{array}{c}227.78 \\
13.0 \\
6.08 \\
-85 \\
1245\end{array}$ & $\begin{array}{c}226.78 \\
11.7 \\
9.10 \\
-100 \\
1637\end{array}$ & $\begin{array}{c}228.07 \\
11.0 \\
6.66 \\
-135 \\
1254\end{array}$ \\
\hline $\begin{array}{l}\text { Arsenic } \\
\text { Barium } \\
\text { Beryilium } \\
\text { Cadmium } \\
\text { Chloride } \\
\text { Chromium } \\
\text { Cobalt } \\
\text { Copper } \\
\text { Iron } \\
\text { Lead } \\
\text { Manganese } \\
\text { Mercury } \\
\text { Nickel } \\
\text { Silver } \\
\text { Thallium } \\
\text { Vanadium } \\
\text { Zinc } \\
\text { Aroclor-1254 } \\
\text { Hydrogen-3 } \\
\text { Bis(2-Ethylhexyl)Phthalate }\end{array}$ & $\begin{array}{l}\mathrm{mg} / \mathrm{L} \\
\mathrm{mg} / \mathrm{L} \\
\mu \mathrm{g} / \mathrm{L} \\
\mathrm{mg} / \mathrm{L} \\
\mathrm{mg} / \mathrm{L} \\
\mathrm{mg} / \mathrm{L} \\
\mathrm{mg} / \mathrm{L} \\
\mathrm{mg} / \mathrm{L} \\
\mathrm{mg} / \mathrm{L} \\
\mathrm{mg} / \mathrm{L} \\
\mathrm{mg} / \mathrm{L} \\
\mu \mathrm{g} / \mathrm{L} \\
\mathrm{mg} / \mathrm{L} \\
\mathrm{mg} / \mathrm{L} \\
\mathrm{mg} / \mathrm{L} \\
\mathrm{mg} / \mathrm{L} \\
\mathrm{mg} / \mathrm{L} \\
\mu \mathrm{g} / \mathrm{L} \\
\mathrm{nCi} / \mathrm{L} \\
\mu \mathrm{g} / \mathrm{L}\end{array}$ & $\begin{array}{l}0.0498 \\
0.7233 \\
0.8 \\
0.0019 \\
89 \\
0.030 \\
0.05 \\
0.14 \\
117.9 \\
0.093 \\
3.110 \\
<0.1 \\
0.092 \\
<0.0005 \\
<0.01 \\
0.058 \\
0.29 \\
- \\
0.642 \\
-\end{array}$ & $\begin{array}{l}0.0341 \\
1.3000 \\
1.3 \\
0.0012 \\
116 \\
0.032 \\
0.04 \\
0.12 \\
90.9 \\
0.082 \\
2.265 \\
<0.1 \\
0.008 \\
<0.0005 \\
<0.01 \\
0.037 \\
0.22 \\
- \\
0.426 \\
-\end{array}$ & $\begin{array}{l}0.0139 \\
0.4140 \\
0.5 \\
0.0018 \\
126 \\
0.015 \\
0.06 \\
0.05 \\
42.2 \\
0.027 \\
1.585 \\
<0.1 \\
0.091 \\
<0.0005 \\
<0.01 \\
0.020 \\
0.10 \\
- \\
0.406 \\
-\end{array}$ & $\begin{array}{rl} & 0.0188 \\
& 0.3480 \\
< & 5.0 \\
< & 0.0050 \\
120 & \\
& 0.043 \\
< & 0.05 \\
& 0.04 \\
53.9 & \\
& 0.038 \\
& 1.610 \\
< & 0.1 \\
0.052 \\
< & 0.0100 \\
< & 0.01 \\
& 0.082 \\
0.12 & \\
4.6 & \\
0.404 & 5\end{array}$ \\
\hline
\end{tabular}


TABLE 6.25

Groundwater Monitoring Results, Sanitary Landfi11 Perimeter We11 \#800100, 1990 m(MSL) 222.28 Ground Surface Elevation 229.15 Casing Material: PVC

\begin{tabular}{|c|c|c|c|c|c|}
\hline Constituent & Units & $03 / 28 / 90$ & $06 / 11 / 90$ & $09 / 26 / 90$ & $12 / 05 / 90$ \\
\hline $\begin{array}{l}\text { Water Elevation } \\
\text { Temperature } \\
\text { pH } \\
\text { Redox } \\
\text { Conductivity }\end{array}$ & $\begin{array}{c}{ }^{\mathrm{m}} \\
{ }^{\circ} \mathrm{C} \\
\mathrm{pH} \\
\mathrm{mV} \\
\mu \mathrm{mhos} / \mathrm{cm} .\end{array}$ & $\begin{array}{c}229.02 \\
9.0 \\
6.81 \\
- \\
690^{-}\end{array}$ & $\begin{array}{c}228.69 \\
10.9 \\
6.63 \\
-55 \\
723\end{array}$ & $\begin{array}{c}227.55 \\
13.5 \\
7.07 \\
-59 \\
740\end{array}$ & $\begin{array}{c}228.99 \\
11.8 \\
6.94 \\
-271 \\
741\end{array}$ \\
\hline $\begin{array}{l}\text { Arsenic } \\
\text { Barium } \\
\text { Beryllium } \\
\text { Cadmium } \\
\text { Chloride } \\
\text { Chromium } \\
\text { Cobalt } \\
\text { Copper } \\
\text { Iron } \\
\text { Lead } \\
\text { Manganese } \\
\text { Mercury } \\
\text { Nickel } \\
\text { Selenium } \\
\text { Silver } \\
\text { Thallium } \\
\text { Vanadium } \\
\text { Zinc } \\
\text { Hydrogen-3 }\end{array}$ & $\begin{array}{l}\mathrm{mg} / \mathrm{L} \\
\mathrm{mg} / \mathrm{L} \\
\mu \mathrm{g} / \mathrm{L} \\
\mathrm{mg} / \mathrm{L} \\
\mathrm{mg} / \mathrm{L} \\
\mathrm{mg} / \mathrm{L} \\
\mathrm{mg} / \mathrm{L} \\
\mathrm{mg} / \mathrm{L} \\
\mathrm{mg} / \mathrm{L} \\
\mathrm{mg} / \mathrm{L} \\
\mathrm{mg} / \mathrm{L} \\
\mu \mathrm{g} / \mathrm{L} \\
\mathrm{mg} / \mathrm{L} \\
\mathrm{mg} / \mathrm{L} \\
\mathrm{mg} / \mathrm{L} \\
\mathrm{mg} / \mathrm{L} \\
\mathrm{mg} / \mathrm{L} \\
\mathrm{mg} / \mathrm{L} \\
\mathrm{nC} i / \mathrm{L}\end{array}$ & $\begin{aligned} & 0.0067 \\
& 0.1413 \\
< & 0.2 \\
& 0.0011 \\
& 4 \\
& 0.004 \\
< & 0.03 \\
< & 0.01 \\
& 8.1 \\
& 0.008 \\
& 0.263 \\
< & 0.1 \\
< & 0.025 \\
< & 0.005 \\
< & 0.0005 \\
< & 0.01 \\
< & 0.015 \\
& 0.02 \\
& 0.163\end{aligned}$ & $\begin{aligned} & 0.0031 \\
& 0.1002 \\
< & 0.2 \\
& 0.0005 \\
& 5 \\
< & 0.004 \\
< & 0.03 \\
< & 0.01 \\
& 6.3 \\
& 0.004 \\
& 0.228 \\
< & 0.1 \\
< & 0.025 \\
& - \\
< & 0.0005 \\
< & 0.01 \\
< & 0.015 \\
& 0.01 \\
& 0.154\end{aligned}$ & $\begin{aligned} & 0.0114 \\
& 0.0923 \\
< & 0.2 \\
& 0.0050 \\
& 8 \\
& 0.014 \\
< & 0.03 \\
& 0.03 \\
& 18.0 \\
& 0.012 \\
& 0.393 \\
< & 0.1 \\
& 0.054 \\
& - \\
< & 0.0005 \\
< & 0.01 \\
< & 0.015 \\
& 0.06 \\
& 0.100\end{aligned}$ & $\begin{aligned} & 0.0048 \\
& 0.0710 \\
< & 5.0 \\
< & 0.0050 \\
5 & \\
& 0.012 \\
< & 0.05 \\
& 0.01 \\
& 6.1 \\
& 0.006 \\
& 0.229 \\
< & 0.1 \\
< & 0.040 \\
& - \\
< & 0.0100 \\
< & 0.01 \\
& 0.059 \\
& 0.01 \\
< & 0.100\end{aligned}$ \\
\hline
\end{tabular}


TABLE 6.26

Groundwater Monitoring Results, Sanitary Landfill Perimeter We11 \#800130, 1990

$\begin{array}{ll}\text { We11 Point Elevation } & \mathrm{m}(\mathrm{MSL}) \\ \text { Ground Surface Elevation } & 239.66 \\ \text { Casing Material: } & \text { PVC }\end{array}$

\begin{tabular}{|c|c|c|c|c|c|c|}
\hline Constituent & Units & $03 / 28 / 90$ & $06 / 12 / 90$ & $06 / 12 / 90$ & $09 / 18 / 90$ & $12 / 05 / 90$ \\
\hline $\begin{array}{l}\text { Water Elevation } \\
\text { Temperature } \\
\text { pH } \\
\text { Redox } \\
\text { Conductivity }\end{array}$ & $\begin{array}{c}{ }^{\mathrm{m}} \\
{ }^{\circ} \mathrm{C} \\
\mathrm{pH} \\
\mathrm{mV} \\
\mu \text { mhos } / \mathrm{cm}\end{array}$ & $\begin{array}{c}217.53 \\
10.8 \\
6.69 \\
- \\
645\end{array}$ & $\begin{array}{l}217.98 \\
12.7 \\
6.38 \\
-96 \\
627\end{array}$ & $\begin{array}{l}217.98 \\
12.7 \\
6.38 \\
-96 \\
627\end{array}$ & $\begin{array}{c}217.54 \\
10.8 \\
8.10 \\
-136 \\
1127\end{array}$ & $\begin{array}{c}217.60 \\
10.3 \\
6.86 \\
-159 \\
741\end{array}$ \\
\hline $\begin{array}{l}\text { Arsenic } \\
\text { Barium } \\
\text { Beryllium } \\
\text { Cadmium } \\
\text { Chloride } \\
\text { Chromium } \\
\text { Cobalt } \\
\text { Copper } \\
\text { Iron } \\
\text { Lead } \\
\text { Manganese } \\
\text { Mercury } \\
\text { Nickel } \\
\text { Selenium } \\
\text { Silver } \\
\text { Thallium } \\
\text { Vanadium } \\
\text { Zinc } \\
\text { Hydrogen-3 }\end{array}$ & $\begin{array}{l}\mathrm{mg} / \mathrm{L} \\
\mathrm{mg} / \mathrm{L} \\
\mu \mathrm{g} / \mathrm{L} \\
\mathrm{mg} / \mathrm{L} \\
\mathrm{mg} / \mathrm{L} \\
\mathrm{mg} / \mathrm{L} \\
\mathrm{mg} / \mathrm{L} \\
\mathrm{mg} / \mathrm{L} \\
\mathrm{mg} / \mathrm{L} \\
\mathrm{mg} / \mathrm{L} \\
\mathrm{mg} / \mathrm{L} \\
\mu \mathrm{g} / \mathrm{L} \\
\mathrm{mg} / \mathrm{L} \\
\mathrm{mg} / \mathrm{L} \\
\mathrm{mg} / \mathrm{L} \\
\mathrm{mg} / \mathrm{L} \\
\mathrm{mg} / \mathrm{L} \\
\mathrm{mg} / \mathrm{L} \\
\mathrm{nCi} / \mathrm{L} .\end{array}$ & $\begin{aligned} & 0.0040 \\
& 0.2273 \\
< & 0.2 \\
& 0.0038 \\
& 22 \\
< & 0.004 \\
< & 0.03 \\
< & 0.01 \\
& 4.8 \\
& 0.004 \\
& 0.058 \\
& 0.1 \\
< & 0.025 \\
< & 0.005 \\
< & 0.0005 \\
< & 0.01 \\
< & 0.015 \\
& 0.01 \\
& 0.127\end{aligned}$ & $\begin{aligned} & 0.0047 \\
& 0.1685 \\
< & 0.2 \\
& 0.0021 \\
& 30 \\
< & 0.004 \\
< & 0.03 \\
< & 0.01 \\
& 5.5 \\
< & 0.002 \\
& 0.068 \\
< & 0.1 \\
< & 0.025 \\
< & - \\
< & 0.0005 \\
< & 0.01 \\
< & 0.015 \\
< & 0.01 \\
< & 0.100\end{aligned}$ & $\begin{aligned} & 0.0047 \\
& 0.1715 \\
< & 0.2 \\
& 0.0019 \\
& 28 \\
< & 0.004 \\
< & 0.03 \\
& 0.01 \\
& 5.4 \\
< & 0.002 \\
& 0.069 \\
< & 0.1 \\
< & 0.025 \\
< & - \\
< & 0.0005 \\
< & 0.01 \\
< & 0.015 \\
< & 0.01 \\
& -\end{aligned}$ & $\begin{aligned} & 0.0030 \\
& 0.1892 \\
< & 0.2 \\
& 0.0011 \\
& 21 \\
< & 0.004 \\
< & 0.03 \\
< & 0.01 \\
& 4.8 \\
< & 0.002 \\
& 0.052 \\
< & 0.1 \\
& 0.030 \\
& - \\
< & 0.0005 \\
< & 0.01 \\
< & 0.015 \\
< & 0.01 \\
< & 0.100\end{aligned}$ & $\begin{aligned} & 0.0043 \\
& 0.1530 \\
< & 5.0 \\
< & 0.0050 \\
& 34 \\
& 0.012 \\
< & 0.05 \\
< & 0.01 \\
& 6.3 \\
< & 0.002 \\
& 0.108 \\
< & 0.1 \\
< & 0.040 \\
< & - \\
< & 0.0100 \\
< & 0.01 \\
& 0.053 \\
& 0.01 \\
& 0.105\end{aligned}$ \\
\hline
\end{tabular}


TABLE 6.27

Groundwater Monitoring Results, Sanitary Landfi11 Perimeter We11 \#800001, 1990

\begin{tabular}{|c|c|c|c|c|c|}
\hline \multirow[b]{2}{*}{ Constituent } & \multirow[b]{2}{*}{ Units } & \multirow[b]{2}{*}{$04 / 09 / 90$} & \multicolumn{2}{|c|}{$\begin{array}{l}\text { Well Point Elevation } \\
\text { Ground Surface Elevation } \\
\text { Casing Material: }\end{array}$} & \multirow{2}{*}{$\begin{array}{l}m(M S L) \\
183.13 \\
229.53 \\
\text { Steel } \\
12 / 06 / 90\end{array}$} \\
\hline & & & $06 / 11 / 90$ & $09 / 18 / 90$ & \\
\hline $\begin{array}{l}\text { Water Elevation } \\
\text { Temperature } \\
\mathrm{pH} \\
\text { Redox } \\
\text { Conductivity }\end{array}$ & $\begin{array}{c}{ }^{\mathrm{m}} \\
{ }^{\circ} \mathrm{C} \\
\mathrm{pH} \\
\mathrm{mV} \\
\mu \mathrm{mhos} / \mathrm{cm}\end{array}$ & $\begin{array}{c}191.80 \\
11.8 \\
10.84 \\
- \\
392\end{array}$ & $\begin{array}{l}192.00 \\
11.3 \\
9.99 \\
-23 \\
398\end{array}$ & $\begin{array}{l}191.83 \\
11.5 \\
10.58 \\
113 \\
387\end{array}$ & $\begin{array}{l}191.82 \\
10.7 \\
10.73 \\
-71 \\
387\end{array}$ \\
\hline $\begin{array}{l}\text { Arsenic } \\
\text { Barium } \\
\text { Beryllium } \\
\text { Cadmium } \\
\text { Chloride } \\
\text { Chromium } \\
\text { Cobalt } \\
\text { Copper } \\
\text { Iron } \\
\text { Lead } \\
\text { Manganese } \\
\text { Mercury } \\
\text { Nickel } \\
\text { Selenium } \\
\text { Silver } \\
\text { Thallium } \\
\text { Vanadium } \\
\text { Zinc } \\
\text { Hydrogen-3 } \\
\text { 2-Butanone } \\
\text { 2-Hexanone } \\
\text { Acetone }\end{array}$ & $\begin{array}{l}\mathrm{mg} / \mathrm{L} \\
\mathrm{mg} / \mathrm{L} \\
\mu \mathrm{g} / \mathrm{L} \\
\mathrm{mg} / \mathrm{L} \\
\mathrm{mg} / \mathrm{L} \\
\mathrm{mg} / \mathrm{L} \\
\mathrm{mg} / \mathrm{L} \\
\mathrm{mg} / \mathrm{L} \\
\mathrm{mg} / \mathrm{L} \\
\mathrm{mg} / \mathrm{L} \\
\mathrm{mg} / \mathrm{L} \\
\mu \mathrm{g} / \mathrm{L} \\
\mathrm{mg} / \mathrm{L} \\
\mathrm{mg} / \mathrm{L} \\
\mathrm{mg} / \mathrm{L} \\
\mathrm{mg} / \mathrm{L} \\
\mathrm{mg} / \mathrm{L} \\
\mathrm{mg} / \mathrm{L} \\
\mathrm{nC} \mathrm{i} / \mathrm{L} \\
\mu \mathrm{g} / \mathrm{L} \\
\mu \mathrm{g} / \mathrm{L} \\
\mu \mathrm{g} / \mathrm{L}\end{array}$ & $\begin{aligned}< & 0.0025 \\
& 0.0102 \\
< & 0.2 \\
& 0.0004 \\
& 47 \\
& <0.004 \\
< & 0.03 \\
< & 0.01 \\
& 11.0 \\
& 0.007 \\
& 0.066 \\
< & 0.1 \\
< & 0.025 \\
< & 0.005 \\
< & 0.0005 \\
< & 0.01 \\
< & 0.015 \\
< & 0.01 \\
& 0.143 \\
& 16 \\
& 3 \\
& 60\end{aligned}$ & $\begin{array}{rl}< & 0.0025 \\
& 0.0075 \\
< & 0.2 \\
< & 0.0003 \\
5 & 0 \\
< & 0.004 \\
< & 0.03 \\
< & 0.01 \\
& 3.5 \\
& 0.003 \\
< & 0.015 \\
< & 0.1 \\
< & 0.025 \\
& - \\
< & 0.0005 \\
< & 0.01 \\
< & 0.015 \\
< & 0.01 \\
& 0.173 \\
& 13 \\
& - \\
& 66\end{array}$ & $\begin{aligned}< & 0.0025 \\
& 0.0077 \\
< & 0.2 \\
& 0.0003 \\
& 48 \\
< & 0.004 \\
< & 0.03 \\
< & 0.01 \\
& 3.0 \\
< & 0.002 \\
& 0.015 \\
< & 0.1 \\
& 0.054 \\
& - \\
< & 0.0005 \\
< & 0.01 \\
< & 0.015 \\
< & 0.01 \\
& 0.133 \\
& 17 \\
& - \\
& 59\end{aligned}$ & $\begin{aligned}< & 0.0025 \\
< & 0.0100 \\
< & 5.0 \\
< & 0.0050 \\
& 43 \\
< & 0.010 \\
< & 0.05 \\
< & 0.01 \\
& 4.6 \\
< & 0.002 \\
& 0.030 \\
< & 0.1 \\
< & 0.040 \\
& - \\
< & 0.0100 \\
< & 0.01 \\
< & 0.050 \\
< & 0.01 \\
& 0.129 \\
& 14 \\
& 3 \\
& 53\end{aligned}$ \\
\hline
\end{tabular}


TABLE 6.28

Groundwater Monitoring Results, Sanitary Landfi11 Perimeter We11 \#800002, 1990

\begin{tabular}{|c|c|c|c|c|c|}
\hline \multirow[b]{2}{*}{ Constituent } & \multirow[b]{2}{*}{ Units } & \multirow[b]{2}{*}{$04 / 09 / 90$} & \multicolumn{2}{|c|}{$\begin{array}{l}\text { We11 Point Elevation } \\
\text { Ground Surface Elevation } \\
\text { Casing Material: }\end{array}$} & \multirow{2}{*}{$\begin{array}{l}m(M S L) \\
182.31 \\
227.81 \\
\text { Stee1 } \\
12 / 06 / 90\end{array}$} \\
\hline & & & $06 / 12 / 90$ & $09 / 18 / 90$ & \\
\hline $\begin{array}{l}\text { Water Elevation } \\
\text { Temperature } \\
\text { pH } \\
\text { Redox } \\
\text { Conductivity }\end{array}$ & $\begin{array}{c}{ }^{\mathrm{m}} \\
{ }^{\circ} \mathrm{C} \\
\mathrm{pH} \\
\mathrm{mV} \\
\mu m \operatorname{mos} / \mathrm{cm}\end{array}$ & $\begin{array}{c}190.80 \\
- \\
6.97 \\
779^{-}\end{array}$ & $\begin{array}{c}190.91 \\
13.0 \\
8.20 \\
-102 \\
233\end{array}$ & $\begin{array}{l}190.81 \\
11.6 \\
9.58 \\
-93 \\
114\end{array}$ & $\begin{array}{c}190.81 \\
10.4 \\
8.14 \\
1988 \\
398\end{array}$ \\
\hline $\begin{array}{l}\text { Arsenic } \\
\text { Barium } \\
\text { Beryllium } \\
\text { Cadmium } \\
\text { Chloride } \\
\text { Chromium } \\
\text { Cobalt } \\
\text { Copper } \\
\text { Iron } \\
\text { Lead } \\
\text { Manganese } \\
\text { Mercury } \\
\text { Nickel } \\
\text { Selenium } \\
\text { Silver } \\
\text { Thallium } \\
\text { Vanadium } \\
\text { Zinc } \\
\text { Hydrogen-3 } \\
\text { Di-N-Octyl Phthalate }\end{array}$ & $\begin{array}{l}\mathrm{mg} / \mathrm{L} \\
\mathrm{mg} / \mathrm{L} \\
\mu \mathrm{g} / \mathrm{L} \\
\mathrm{mg} / \mathrm{L} \\
\mathrm{mg} / \mathrm{L} \\
\mathrm{mg} / \mathrm{L} \\
\mathrm{mg} / \mathrm{L} \\
\mathrm{mg} / \mathrm{L} \\
\mathrm{mg} / \mathrm{L} \\
\mathrm{mg} / \mathrm{L} \\
\mathrm{mg} / \mathrm{L} \\
\mu \mathrm{g} / \mathrm{L} \\
\mathrm{mg} / \mathrm{L} \\
\mathrm{mg} / \mathrm{L} \\
\mathrm{mg} / \mathrm{L} \\
\mathrm{mg} / \mathrm{L} \\
\mathrm{mg} / \mathrm{L} \\
\mathrm{mg} / \mathrm{L} \\
\mathrm{nC} i / \mathrm{L} \\
\mu \mathrm{g} / \mathrm{L}\end{array}$ & $\begin{aligned} & 0.0043 \\
& 0.0550 \\
&< 0.2 \\
& 0.0018 \\
& 67 \\
&< 0.004 \\
&< 0.03 \\
&< 0.01 \\
& 13.0 \\
& 0.008 \\
& 0.085 \\
&< 0.1 \\
&< 0.025 \\
&< 0.005 \\
&< 0.0005 \\
&< 0.01 \\
&< 0.015 \\
&< 0.01 \\
&< 0.100 \\
&-\end{aligned}$ & $\begin{aligned} & 0.0025 \\
& 0.0108 \\
< & 0.2 \\
& 0.0004 \\
& 11 \\
< & 0.004 \\
< & 0.03 \\
< & 0.01 \\
& 4.3 \\
< & 0.002 \\
& 0.020 \\
< & 0.1 \\
< & 0.025 \\
< & - \\
< & 0.0005 \\
< & 0.01 \\
< & 0.015 \\
< & 0.01 \\
< & 0.100 \\
& 23\end{aligned}$ & $\begin{aligned}< & 0.0025 \\
& 0.0174 \\
< & 0.2 \\
& 0.0012 \\
& 4 \\
< & 0.004 \\
< & 0.03 \\
< & 0.01 \\
& 24.9 \\
& 0.004 \\
& 0.148 \\
< & 0.1 \\
& 0.054 \\
< & - \\
< & 0.0005 \\
< & 0.01 \\
< & 0.015 \\
< & 0.01 \\
< & 0.100 \\
& -\end{aligned}$ & $\begin{aligned}< & 0.0025 \\
& 0.0210 \\
< & 5.0 \\
< & 0.0050 \\
& 34 \\
< & 0.010 \\
< & 0.05 \\
< & 0.01 \\
& 12.5 \\
< & 0.002 \\
& 0.157 \\
< & 0.1 \\
< & 0.040 \\
& - \\
< & 0.0100 \\
< & 0.01 \\
< & 0.050 \\
< & 0.01 \\
< & 0.100 \\
& -\end{aligned}$ \\
\hline
\end{tabular}


levels vary from $200 \mathrm{mg} / \mathrm{L}$ to $600 \mathrm{mg} / \mathrm{L}$. A11 of the other wells are less than $100 \mathrm{mg} / \mathrm{L}$. The inorganic results for dolomite wells 800001 and 800002 were all within normal ranges with the exception of the $\mathrm{pH}$ in well 800D01 which ranged from 10.7 to 11.8 . This probably results from very high levels of carbonate, the source of which is unknown.

\section{Organic Constituents}

All of the monitoring wells with sufficient recharge rates were sampled quarterly and analyzed for volatile organic compounds. In addition, annual samples were collected from each of the wells and analyzed for semt-volatile organic compounds, PCBs, and pesticides and herbicides. All of the constituents were below the 1 imit of detection except those noted below. Tetrahydrofuran and diethyl ether were tentatively identified in wells 800060 and 800090. Small amounts of several phthalates were found in some wells. These materials are frequently found in waters as well as in background samples. The sample from we11 800090 contained $4.6 \mu \mathrm{g} / \mathrm{L}$ of Aroclor 1254. Previous samples from this location did not indicate its presence. A follow-up sample has been obtained but the results are not yet available. Acetone and 2-butanone were detected in all samples from 800001 and the concentrations ranged from 53 to $66 \mu \mathrm{g} / \mathrm{L}$ for acetone and from 14 to $17 \mu \mathrm{g} / \mathrm{L}$ for 2-butanone. In addition, 2-hexanone was detected in two samples at low levels. The results for these ketones are very similar to previous results and it appears that the water in this well is contaminated with these ketones. Traces of phthalate were detected in we11 800002 .

\section{Radiuactive Constituents}

Samples collected from the 800 Area sanitary landf 111 monitoring wells were also analyzed for hydrogen-3. The results are shown in Table 6.16 to 6.28. Although the disposal of radioactive materials is prohibited in the sanitary landf 111 , very low concentrations of hydrogen-3 were detected, probably due to inadvertent disposal of radioactivity in the ANL trash. However, the presence of hydrogen-3 as tritiated water allows information to be obtained on the subsurface water flow pathway in the sanitary landfill area. The data indicate that the principal direction of subsurface water 
flow is to the south-southeast, with a small component to the northwest. This is consistent with the estimated subsurface water flow based on water level measurements and general flow patterns in the area.

\subsection{CP-5 Reactor Area}

The CP-5 reactor is an inactive research reactor located in building 330 (See Figure 1.1 for location). CP-5 was a 5 megawatt research reactor which was used from 1954 until operations were ceased in 1977. In addition to the reactor vessel itself, the CP-5 complex contained several large cooling towers and an outdoor equipment yard used for storage of equipment and supplies. The reactor and associated yard area is in the process of being decommissioned. There are currently plans to beg in a full characterization of this site, starting in 1993. As a preliminary step to this study, a single exploratory monitoring well was installed in the yard, immediately behind the reactor building, just outside the reactor fue 1 storage area of the complex. This well was sampled quarterly and analyzed for radionuclides, metals and radioactivity. The results are shown in Table 6.29

This well is installed in a relatively porous, saturated region of soil and as a result, recharges quickly. Purging the well by removing several well volumes of water does not lower the water level appreciably. The water has a higher conductivity than simflar wells at other locations. This observation is consistent with high chloride concentrations also observed in this well. Other wells on-site have been found to contain high chloride concentrations; however, most of these were located near roadways which are routinely salted during the winter for ice removal. The area around this well is not subject to these same activities. Relatively high concentrations of iron and manganese were also found. One of the four samples contained measurable amounts of mercury $(0.3 \mu \mathrm{g} / \mathrm{l}$.). Arsenic levels ranged from 3.6 to $4.5 \mu \mathrm{g} / \mathrm{L}$, which is only slightly above the detection limit of 2.5 $\mu \mathrm{g} / \mathrm{L}$. Though these results are low, it is unusual to find any arsenic in groundwater in this area. 
TABLE 6.29

Groundwater Monttoring Resu1ts, 300 Area We11 \#330010, 1990

\begin{tabular}{|c|c|c|c|c|c|}
\hline & & & $\begin{array}{l}\text { We11 Point } \\
\text { Ground Surf } \\
\text { Casing Mate }\end{array}$ & $\begin{array}{l}\text { evation } \\
\text { e Elevation } \\
\text { al: }\end{array}$ & $\begin{array}{l}m(M S L) \\
215.7 \\
222.56 \\
\text { Stee1 }\end{array}$ \\
\hline Constituent & Units & $04 / 09 / 90$ & $06 / 19 / 90$ & $10 / 24 / 90$ & $11 / 16 / 90$ \\
\hline $\begin{array}{l}\text { Water Elevation } \\
\text { Temperature } \\
\mathrm{pH} \\
\text { Redox } \\
\text { Conductivity }\end{array}$ & $\begin{array}{l}{ }^{\mathrm{m}} \\
{ }^{\circ} \mathrm{C} \\
\mathrm{pH} \\
\mathrm{mV} \\
\mu \text { mhos } / \mathrm{cm}\end{array}$ & $\begin{array}{c}220.37 \\
11.6 \\
6.77 \\
- \\
1808\end{array}$ & $\begin{array}{c}220.50 \\
17.1 \\
6.27 \\
-71 \\
1683\end{array}$ & $\begin{array}{c}220.54 \\
17.6 \\
6.73 \\
-42 \\
1411\end{array}$ & $\begin{array}{c}220.53 \\
16.8 \\
6.64 \\
-9 \\
1459\end{array}$ \\
\hline $\begin{array}{l}\text { Arsenic } \\
\text { Barium } \\
\text { Beryllium } \\
\text { Cadmium } \\
\text { Chloride } \\
\text { Chromium } \\
\text { Cobalt } \\
\text { Copper } \\
\text { Iron } \\
\text { Lead } \\
\text { Manganese } \\
\text { Mercury } \\
\text { Nicke1 } \\
\text { Selenium } \\
\text { Silver } \\
\text { Thallium } \\
\text { Vanadium } \\
\text { Zinc } \\
\text { Cesium-137 } \\
\text { Hydrogen-3 } \\
\text { Strontium-90 }\end{array}$ & $\begin{array}{l}\mathrm{mg} / \mathrm{L} \\
\mathrm{mg} / \mathrm{L} \\
\mu \mathrm{g} / \mathrm{L} \\
\mathrm{mg} / \mathrm{L} \\
\mathrm{mg} / \mathrm{L} \\
\mathrm{mg} / \mathrm{L} \\
\mathrm{mg} / \mathrm{L} \\
\mathrm{mg} / \mathrm{L} \\
\mathrm{mg} / \mathrm{L} \\
\mathrm{mg} / \mathrm{L} \\
\mathrm{mg} / \mathrm{L} \\
\mu \mathrm{g} / \mathrm{L} \\
\mathrm{mg} / \mathrm{L} \\
\mathrm{mg} / \mathrm{L} \\
\mathrm{mg} / \mathrm{L} \\
\mathrm{mg} / \mathrm{L} \\
\mathrm{mg} / \mathrm{L} \\
\mathrm{mg} / \mathrm{L} \\
\mathrm{pCi} / \mathrm{L} \\
\mathrm{nCi} i / \mathrm{L} \\
\mathrm{pCi} i / \mathrm{L}\end{array}$ & $\begin{array}{rl} & 0.0039 \\
& 0.1854 \\
& 0.2 \\
& 0.0063 \\
367 & \\
< & 0.004 \\
< & 0.03 \\
< & 0.01 \\
& 9.6 \\
& 0.010 \\
& 1.558 \\
< & 0.1 \\
< & 0.025 \\
< & 0.005 \\
< & 0.0005 \\
< & 0.01 \\
< & 0.015 \\
& 0.02 \\
< & 1 \\
15.900 & 3.32\end{array}$ & $\begin{aligned} & 0.0043 \\
& 0.1061 \\
& 0.2 \\
& 0.0012 \\
& 269 \\
&<0.004 \\
&<0.03 \\
& 0.01 \\
& 7.4 \\
& 0.006 \\
& 1.178 \\
&<0.1 \\
&<0.025 \\
&<0.0005 \\
&<0.01 \\
&<0.015 \\
& 0.01 \\
&<1 \\
& 10.000 \\
& 2.59\end{aligned}$ & 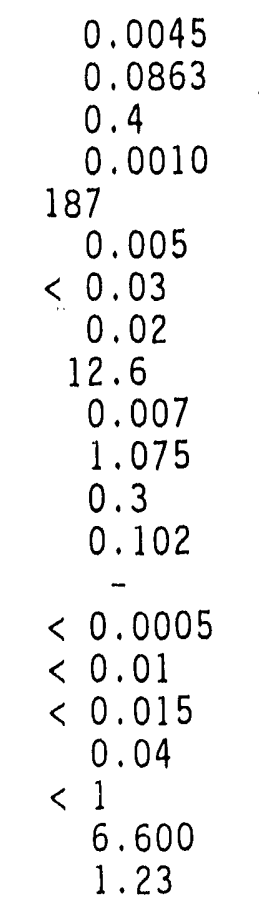 & $\begin{aligned} & 0.0036 \\
& 0.1050 \\
< & 5.0 \\
< & 0.0050 \\
182 & \\
& 0.019 \\
< & 0.05 \\
< & 0.01 \\
& 14.4 \\
& 0.009 \\
& 1.180 \\
< & 0.1 \\
< & 0.040 \\
< & - \\
< & 0.0100 \\
< & 0.01 \\
& 0.066 \\
& 0.07 \\
< & 1 \\
& 6.500 \\
& 1.40\end{aligned}$ \\
\hline
\end{tabular}


There were no volatile organic compounds identified in any of the samples, indicating no significant organic contamination of this area. Since there were none identified, Table 6.29 does not show any volatile organic analysis results.

The levels of hydrogen-3 ranged from 6.5 to $15.9 \mathrm{nCi} / \mathrm{L}$ and the level of strontium-90 ranged from 1.4 to $3.32 \mathrm{pCi} / \mathrm{L}$. A11 values for cesium-137 were below the detection 1 imit of $1.0 \mathrm{pCi} / \mathrm{L}$. CP-5 was a heavy water-moderated reactor. During its operation 1 ife, several incidents occurred which released small amounts of this heavy water, containing high concentrations of hydrogen-3, to the environment. In addition, the normal operation released significant amounts of water vapor coritaining hydrogen-3 from the main ventilation system which may have condensed and fallen to the ground in the form of precipitation. These activities are believed to be responsible for the residual amounts of hydrogen-3 now found in the groundwater. The source of the strontium-90 is not known.

It is of interest to note that the levels of chloride and radioactivity were seen to decrease significantly during the first three quarters, stabilizing during the final quarter. This could be the result of the well purging and sampling activities pulling less contaminated water into the area around the well, diluting the constituents originally present in the soil and pore water. The additional characterization activities planned for 1993 will define the extent of this contamination.

\subsection{Site Characterization Activities}

Historical information about waste disposal activities on the ANL site, as well as groundwater monitoring results, indicate that several sites are either currently releasing small amounts of hazardous materials to the environment or have the potential to do so in the future. As a first step to stopping these releases and cleaning up any residual contamination, a series of site characterization projects are underway. To date, these projects have focused on the most significant sites, the 800 Area landfill and the $317 / 319$ Areas. The studies are in the preliminary stages, and thus the information available is currently incomplete and may not accurately 
represent the actual conditions at these sites. Characterization activities are currentiy scheduled to extend beyond 1994.

\subsubsection{Area Landfill Characterization}

The characterization activities at the landfill have thus far been limited to the collection of a series of soil gas and shallow groundwater samples from in and near the fill material. The results of this analysis have shown that significant amounts of volatile organic compounds are present in the fill material and leachate. A large number of compounds have been detected, most of which are listed on the log of wastes poured into the old French drain in the north end of the site. It appears that volatile organics are present throughout most of the fill material. The distribution of these chemicals throughout the fill was found to be highly variable, indicating the possibility of multiple sources within the waste.

In addition to volatile organics, a number of semivolatile organics have also been identified including benzoic acid, phenol and several substituted phenols, a number of phthalates and several polynuclear aromatic hydrocarbons. The concentration of these compounds was generally lower than the volatile organics.

One sampling point, near the site of the French drain, yielded a sample containing significant amounts (over $109 \mu \mathrm{g} / \mathrm{L}$ total) of two different PCBs, Aroclor 1254 and Aroclor 1260. The sample contained a small amount of floating oil, indicating that the source of PCB was probably the disposal of PCB-containing waste oils. One monitoring we11, No. 800090 , has shown measurable amounts of the PCB Aroclor 1254 on at least one occasion.

Additional characterization activities planned for 1991 and beyond will more completely define the nature and amount of contaminants present in the fill material. A detailed hydrogeological study will be conducted to identify the location, direction of movement and velocity of groundwater below the landfill and to determine the potential for migration of these chemicals off-site. The magnitude of any existing groundwater contamination will also be determined. Remedial actions necessary to clean up or contain the 
hazardous constituents in the 1 andfill and groundwater will then be selected and implemented.

\subsubsection{7/319 Area Characterization}

A similar study was conducted in the $317 / 319$ Area involving the collection of soil gas and shallow groundwater samples. The data generated by this s,tudy indicates that two distinct areas of highly contaminated soil exist, one near the site of the French drain in the 317 Area and the other in the 319 Area landfill. A larger number of organic compounds were identified in the 317 Area, some at very high concentrations (over 100,000 $\mu \mathrm{g} / \mathrm{L}$ ). A relatively small area of highly contaminated soil was found to exist, just north of the vaults used for storage of radioactive wastes. Significant, but much lower concentrations of volatile organics were found several hundred feet from the vault area, indicating that movement of the contamination through the soil is occurring. This is consistent with the results of the monitoring well sampling discussed in this chapter. Samples of shallow groundwater [less than $3 \mathrm{~m}(10 \mathrm{ft})$ deep] collected on Forest Preserve property south of the ANL fenceline indicate that low levels of several ketones have moved off-site. The depth and extent of groundwater contamination is not fully defined at this point.

The 319 Area, which contained a similar French drain, was al so found to contain a large number of organic compounds, although the concentrations were much lower than in the 317 Area. The French drain in this area was much deeper than the one in the 317 area. Since the techniques used in this preliminary investigation were limited to a depth of approximately $3 \mathrm{~m}$ (10 $\mathrm{ft}$ ) below the surface, they may not have been able to detect contamination located deep within the 319 waste pile.

One sample recovered from the 319 area was found to contain relatively high concentrations of two PCBs Aroclor 1254 and Aroclor $1260(220 \mu \mathrm{g} / \mathrm{L}$ total). A floating oil layer was encountered at this point, indicating the PCBs were the result of disposal of PCB-containing waste oils. 
Additional characterization activities planned for 1991 and beyond will better define the nature and extent of soil and groundwater contamination and will determine if hazardous materials have migrated into underlying aquifers. A detailed hydrogeological study will be conducted to define the location, direction of movement and velocity of groundwater below the $317 / 319$ Area. Remedial actions necessary to clean up or contain the hazardous constituents in this area will then be selected and implemented. 


\section{QUALITY ASSURANCE}

Quality Assurance (QA) plans exist for both radiological (H 0030-0003QA-00) and non-radiological (H 0030-0002-QA-01) analyses. Both QA documents were prepared in accordance with ANSI/ASMC NQA-1 and meet the requirements of ANL QA documents. ${ }^{23,24}$ The plans discuss responsibilities and auditability. Both documents are supplemented by operating manuals.

\subsection{Radiochemical Analysis and Radioactivity Measurements}

All nuclear instrumentation is calibrated with standard sources obtained from the National Institute of Standards and Technology (NIST), if possible. If NIST standards are not available for particular nuclides, NIST traceable standards from the Amersham Corporation are used. The equipment is usually checked daily with secondary counting standards to ensure proper operation. Samples are periodically analyzed in duplicate or with the addition of known amounts of a radionuclide to check precision and accuracy. When a nuclide was not detected, the result is given as "less than" $(<)$ the minimum amount detectable (detection $1 \mathrm{imit}$ ) by the analytical method used. The detection limits were chosen so that the measurement uncertainty at the $95 \%$ confidence level is equal to the measured value. The air and water detection limits (minimum detectable amounts) for all radionuclides for which measurements were made are given in Table 7.1. The relative error in a result decreases with increasing concentration. At a concentration equal to twice the detection 1 imit, the error is about $50 \%$ of the measured value and at ten times the detection 1 imit, the error is about $10 \%$.

Average values are usually accompanied by a plus-or-minus ( \pm ) limit value. Unless otherwise stated, this value is the standard error at the $95 \%$ confidence level calculated from the standard deviation of the average. The \pm limit value is a measure of the range in the concentrations encountered at that location; it does not represent the conventional uncertainty in the average of repeated measurements on the same or identical samples. Since many of the variations observed in environmental radioactivity are not random but occur for specific reasons (e.g., seasonal variations), samples collected from the same location at different times are not replicates. The 
TABLE 7.1

Detection Limits

\begin{tabular}{|c|c|c|}
\hline $\begin{array}{l}\text { Nuclide or } \\
\text { Activity }\end{array}$ & $\begin{array}{c}\text { Air } \\
\left(\mathrm{fC} i / \mathrm{m}^{3}\right)\end{array}$ & $\begin{array}{l}\text { Water } \\
(\mathrm{pC} i / L)\end{array}$ \\
\hline Americium-241 & - & 0.001 \\
\hline Bery 11 ium-7 & 5 & - \\
\hline Cal ifornium-249 & - & 0.001 \\
\hline Cal ifornium-252 & - & 0.001 \\
\hline Cesium-137 & 0.1 & 1 \\
\hline Curium-242 & - & 0.001 \\
\hline Curium-244 & - & 0.001 \\
\hline Hydrogen-3 & 100 & 100 \\
\hline Lead-210 & 1 & - \\
\hline Neptunium-237 & - & 0.001 \\
\hline Plutonium-238 & 0.0003 & 0.001 \\
\hline Plutonium-239 & 0.0003 & 0.001 \\
\hline Radium-226 & - & 0.1 \\
\hline Strontium-89 & 0.1 & 2 \\
\hline Strontium-90 & 0.01 & 0.25 \\
\hline Thorium-228 & 0.001 & - \\
\hline Thorium-230 & 0.001 & - \\
\hline Thorium-232 & 0.001 & - \\
\hline Uranium-234 & 0.0003 & 0.01 \\
\hline Uranium-235 & 0.0003 & 0.01 \\
\hline Uranium-238 & 0.0003 & 0.01 \\
\hline Uranium - natural & 0.02 & 0.2 \\
\hline Alpha & 0.2 & 0.2 \\
\hline Beta & 0.5 & 1 \\
\hline
\end{tabular}


more random the variation in activity at a particular location, the closer the confidence limits will represent the actual distribution of values at that location. The averages and confidence limits should be interpreted with this in mind. When a plus-or-minus value accompanies an individual result in this report, it represents the statistical counting error at the $95 \%$ confidence leve1.

Standard and intercomparison samples distributed by the Quality Assurance Branch of the EPA are analyzed regularly. Results of ANL's partici-pation in the EPA program during 1990 are given in Table 7.2. In the table, the comparison is made between the EPA value, which is the quantity added to the sample by that laboratory, is compared with the value obtained in the ANL 1aboratory. Certain information may assist in judging the quality of the results, including the fact that typical uncertainties for the ANL analyses are $2 \%$ to $50 \%$, depending on the concentration and the nuclide, and the uncertainties in the EPA results are $2 \%$ to $5 \%$ (ANL estimate).

In addition, participation continued in the DOE Environmental Measurements Laboratory Quality Assurance Program (DOE-EML-QAP), a semi-annual distribution of four different sample matrices containing various combinations of radionuclides that are analyzed. Results for 1990 are summarized in Table 7.3. In the table, the EML value, which is the result of duplicate determinations by that laboratory, is compared with the average value obtained in the ANL laboratory. Information that will assist in judging the quality of the results includes the fact that typical uncertainties for ANL's analyses are $2 \%$ to $50 \%$ and that the uncertainties in the EML results are $1 \%$ to $30 \%$ (depending on the nuclide and the amount present). For most analyses for which the differences are large (>20\%), the concentrations were quite low and the differences were within the measurement uncertainties.

\subsection{Chemical Analysis}

The documentation for non-radiological analyses is contained in an Industrial Hygeine Operating Manual (IHOM), which includes a sampling and analysis plan, as well as individual analytical and collection procedures. 
TABLE 7.2

Summary of EPA Samples, 1990

\begin{tabular}{|c|c|c|c|}
\hline $\begin{array}{l}\text { Type of } \\
\text { Sample }\end{array}$ & Analysis & $\begin{array}{l}\text { Number } \\
\text { Analyzed }\end{array}$ & $\begin{array}{l}\text { Average Difference } \\
\text { from Added }(\%)\end{array}$ \\
\hline Air Filter & $\begin{array}{l}\text { Total Alpha } \\
\text { Total Beta } \\
\text { Strontium-90 } \\
\text { Cesium- } 137\end{array}$ & $\begin{array}{l}2 \\
2 \\
2 \\
2\end{array}$ & $\begin{array}{l}15 \\
10 \\
10 \\
18\end{array}$ \\
\hline Milk & $\begin{array}{l}\text { Potassium-40 } \\
\text { Strontium-89 } \\
\text { Strontium-90 } \\
\text { Iodine-131 } \\
\text { Cesium-137 }\end{array}$ & $\begin{array}{l}2 \\
2 \\
2 \\
2 \\
2\end{array}$ & $\begin{array}{l}2 \\
5 \\
8 \\
2 \\
4\end{array}$ \\
\hline Water & $\begin{array}{l}\text { Hydrogen-3 } \\
\text { Cobalt-60 } \\
\text { Zinc-65 } \\
\text { Strontium-89 } \\
\text { Strontium-90 } \\
\text { Ruthenium-106 } \\
\text { Iodine-131 } \\
\text { Cesium-134 } \\
\text { Cesium-137 } \\
\text { Barium-133 } \\
\text { Radium-226 } \\
\text { Radium-228 } \\
\text { Total Uranium } \\
\text { Plutonium-239 }\end{array}$ & $\begin{array}{l}2 \\
2 \\
2 \\
3 \\
3 \\
2 \\
1 \\
3 \\
3 \\
2 \\
2 \\
2 \\
3 \\
2\end{array}$ & $\begin{array}{r}5 \\
1 \\
1 \\
8 \\
13 \\
7 \\
7 \\
9 \\
3 \\
8 \\
20 \\
32 \\
19 \\
9\end{array}$ \\
\hline
\end{tabular}




\section{TABLE 7.3}

Summary of DOE-EML-QAP Samples, 1990

\begin{tabular}{lcccc} 
& \multicolumn{4}{c}{ Percent Difference From EML Value } \\
\cline { 2 - 6 } Radionuclide & Air Filters & Sol1 & Vegetation & Water \\
\hline Hydrogen-3 & - & - & - & $32(2)$ \\
Beryllium-7 & $0(2)$ & - & - & - \\
Potassium-40 & - & $18(2)$ & $13(2)$ & - \\
Manganese-54 & $4(2)$ & - & - & $0(2)$ \\
Cobalt-57 & $9(2)$ & - & - & $5(2)$ \\
Cobalt-60 & $9(2)$ & - & - & $6(2)$ \\
Strontium-90 & $8(2)$ & $21(2)$ & $8(2)$ & $7(2)$ \\
Cesium-134 & $14(2)$ & - & - & $7(2)$ \\
Cesium-137 & $4(2)$ & $10(2)$ & $2(2)$ & $4(2)$ \\
Cerium-144 & $6(2)$ & - & - & $6(2)$ \\
Uranium-234 & $35(2)$ & $16(2)$ & - & $10(2)$ \\
Uranium-238 & $9(2)$ & $16(2)$ & - & $12(2)$ \\
Plutonium-239 & $8(2)$ & $2(1)$ & $0(1)$ & $12(2)$ \\
Americium-241 & $8(2)$ & $11(1)$ & - & $32(2)$ \\
\hline
\end{tabular}

Note: The value in parentheses is the number of samples. 
A11 samples for NPDES and groundwater are collected and analyzed in accordance with EPA regulations found in EPA-600/4-84-017, ${ }^{25} \mathrm{SW}-846,{ }^{26}$ and 40 CFR Part $136 .^{20}$

Standard Reference Materials (SRM), traceable to the NIST, exist for most inorganic analyses (see Table 7.4). These are replaced annually. A11 standards are compared annually to the NIST values. Detection 1 imits are determined with techniques 1isted in Report SW-846. ${ }^{26}$ In general, the detection 1 imit is the measure of the variability $(\sigma)$ of a standard material measurement at 5-10 times the instrument detection limit as measured over an extended time period. Recovery of inorganic metals, as determined by "spiking" unknown solutions, must be in the range of $75 \%$ to $125 \%$. The precision, as determined by analysis of duplicate samples, must be within $20 \%$. These measurements mus.t be made on at least $10 \%$ of the samples. Comparis on samples for organic constituents are available from the EPA, and many are used in this work. The requirement ${ }^{26}$ for organic analyses depends upon the compounds studied and includes analyses of a matrix spike, specified internal standards, recovery, and relative retention times; at least one sample is run each month. Results for 1990 are shown in Table 7.5, along with the required recoveries.

Argonne participates in the U. S. Environmental Protection Agency Discharge Monitoring Report Quality Assurance Program. Results are rated acceptable by the EPA and are presented in Table 7.6. 
TABLE 7.4

\begin{tabular}{ll}
\multicolumn{2}{c}{ NIST-SRM Used for Inorganic Analysis } \\
\hline NIST-SRM & Contents \\
\hline 3103 & Arsentc \\
3104 & Barium \\
3105 & Beryllium \\
3108 & Cadmium \\
3112 & Chromium \\
3113 & Cobalt \\
3114 & Copper \\
3126 & Iron \\
3128 & Lead \\
3132 & Manganese \\
3133 & Mercury \\
3136 & Nickel \\
3149 & Selenium \\
3151 & Silver \\
3165 & Vanadium \\
3168 & Zinc \\
3181 & Sulfate \\
3182 & Chloride \\
3183 & Fluoride \\
& \\
\hline
\end{tabular}


TABLE 7.5

EPA Qualtty Check Sample Results, 1990

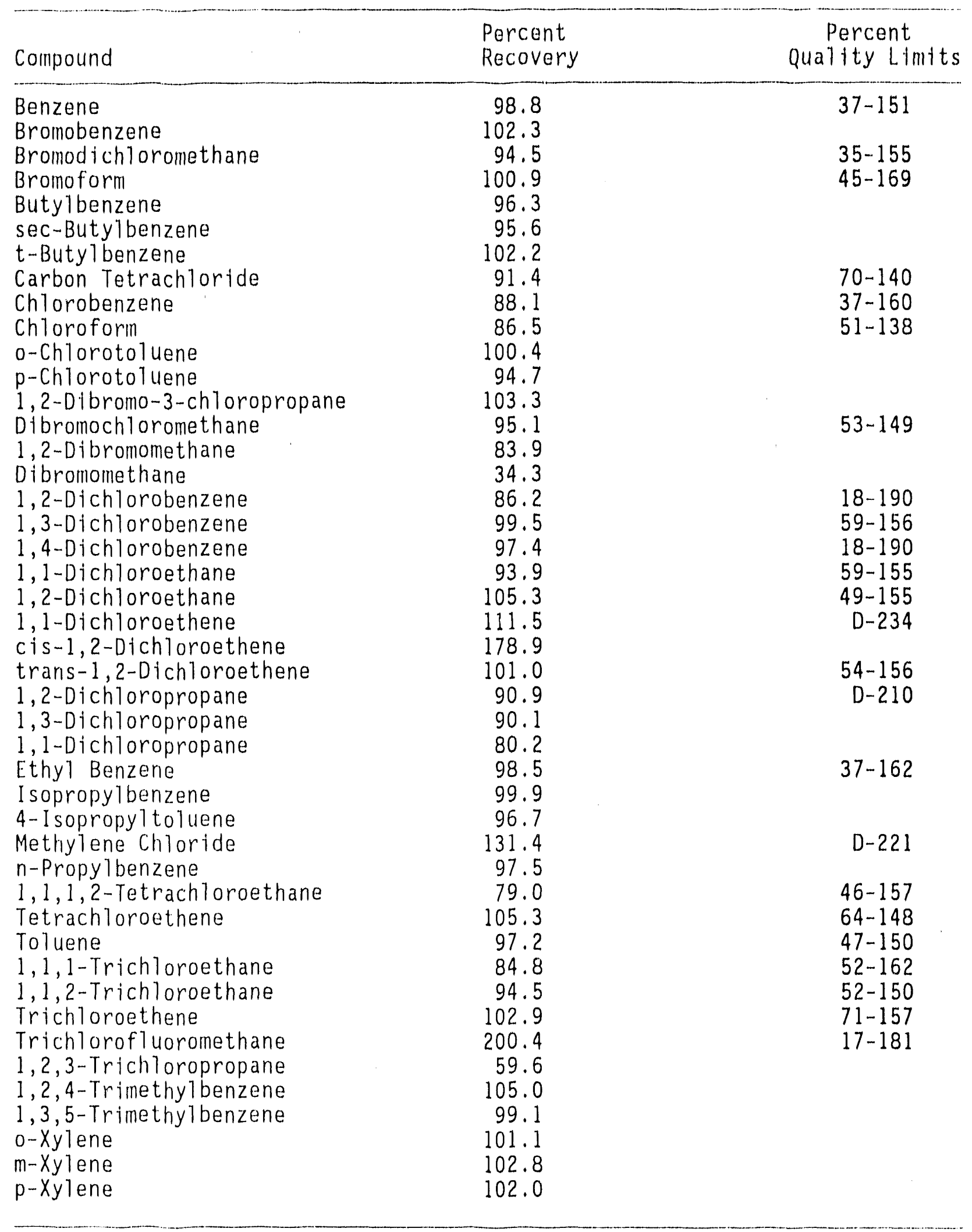

Note: D denotes the compound was detected. 
TABLE 7.6

Sunmary of EPA Nonradiological Samples, 1990

\begin{tabular}{lc} 
Constituent & $\begin{array}{c}\text { Average Difference From } \\
\text { Reference Value (\%) }\end{array}$ \\
\hline Chromium & -2 \\
Copper & +2 \\
Iron & +3 \\
Lead & +3.3 \\
Manganese & +2.0 \\
Mercury & -5.6 \\
pH & -0.1 unit \\
Zinc & +2.9 \\
Total Suspended Solids & -7 \\
O11 and Grease & -20.5 \\
Chemical Oxygen Demand & -14 \\
\hline
\end{tabular}




\section{APPENDIX}

\subsection{References}

1. U. S. Department of Energy, General Environmental Protection Program. DOE Order 5400.1, November 9, 1988.

2. Environmental Assessment Related to the Operation of Argorne National Laboratory, Argonne National Laboratory, Argonne, Illinois, DOE/EA0181 , August 1982.

3. H. Moses and M. A. Bogner, Fifteen-Year Climatological Summary, Jan. 1, 1950-DeC. 31, 1964, U.S.A.E.C. Report ANL-7084 (September 1967); H. Moses and J. H. Willett, Five-Year Climatological Summary, July 1949June 1954, U.S.A.E.C. Report ANL-5592.

4. J. P. Corley, D. H. Denham, R. E. Jaquish, D. E. Michels, A. R. 01sen, and D. A. Waite, A Guide for: Environmental Radiological Surveillance at U.S. Department of Energy Installations, U.S.D.O.E. Report DOE/EP0023 (1981).

5. J. P. Corley and C. D. Corbit, A Guide for Effluent Radiological Measurements at DOE Installations, U.S.D.O.E. Report DOE/EP-0096 (July 1983).

6. U. S. Department of Energy, Radiation Protection of the Public and the Environment, DOE Order 5400.5, February 8, 1990.

7. ICRP Publication 26, "Recommendations of the International Commission on Radiological Protection," Annals of the ICRP, Vol. 1, No. 3, Pergamon Press (1977); ICRP Publication 30, "Limits for Intakes of Radionuclides by Workers," Ibid (1978, et seg).

8. U. S. Department of Energy, Internal Dose Conversion Factors for Calculation of Dose to the Public, DOE/EH-0071, July 1988. 
9. N. W. Golchert and J. Sedlet, "Radiochemical Determination of Plutonium in Erivironmental Water Samples, "Radiochem. Radioanal. Letters, 12, 215 (1972).

10. N. W. Golchert and J. Sedlet, "Determination of Transuranics in Environmental Water," in M. H. Campbell (Ed.), High-Level Radioactive Waste Management, (Proceedings of a Symposium, American Chemical Society, April 1-2, 1974), American Chemical Society, Washington, DC, 1976, p. 152.

11. "Sampling Surface Soil for Radionuclides, C-998-83," 1989 Annual Book of ASTM Standards, Vo1. 12.01, p. 792. "Soil Sample Preparation for the Determination of Radionuclides, C-999-83," Ibid, p. 796.

12. B. G. Bennett, Environmental Aspects of Americium, U.S.D.0.E. Report EML-348, December 1978.

13. N. W. Golchert and T. L. Duffy, Argonne National Laboratory-East Site Environmental Report for Calendar Year 1989, U.S.D.O.E. Report ANL-90/8 (Apri1 1990).

14. U. S. Environmental Protection Agency, National Standards for Hazardous Air Emissions: Standards for Radionuclides, 40 CFR Part 61, Subpart $H$ (1990).

15. ICRP Publication 23, Reference Man: Anatomical, Physiological, and Metabolic Characteristics, International Commission on Radiological Protection, Pergamon Press, New York (1975).

16. U. S. Environmental Protection Agency, National Primary Drinking Water Regulations, 40 CFR Part 141, Federal Register, 50, p. 46900, November $13,1985$.

17. National Council on Radiation Protection and Measurements, Ionizing Radiation Exposure of the Population of the United States, NCRP Report No. 93. September 1. 1987. 
18. State of Illinois, Rules and Regulations, Title 35; Environmental Protection Subtitle C; Water Pollution, Chapter 1, March 22, 1985.

19. U. S. Environmental Protection Agency, EPA Administered Permit Programs: The National Pollutant Discharge El imination System, 40 CFR 122 (September 26, 1984).

20. U. S. Environmental Protection Agency, Test Procedures for the Analys is of Pollutants Under the Clean Water Act, 40 CFR 136 (1986).

21. U. S. Environmental Protection Agency, RCRA Ground-Water Monitoring Technical Enforcement Guidance Document, OSWER-9950.1 (Sept. 1986).

22. Application for Permit to Develop and/or Operate a Solid Waste Management Site, Soil Testing Services, Inc., Northbrook, IL, for Argonne National Laboratory, STS Job No. 14236-P, June 30, 1980.

23. Argonne National Laboratory, Unpublished Information, 1985.

24. Argonne National Laboratory, Unpublished Information, 1988.

25. U. S. Environmental Protection Agency, Methods for Chemical Analys is of Water and Wastes, EPA-600/4-84-017 (March 1984).

26. U. S. Environmental Protection Agency, Test Methods for Evaluating Solid Waste, SW-846, Third Edition (Nov. 1986). 


\subsection{Acknowledgements}

We are indebted to R. G. Kolzow (QES), who reviewed the environmental compliance information in Chapter 2 and to the ANL-ESH Health Physics Section, who provided most of the radioactive gaseous effluent data. Some analytical data in Chapter 5 was provided by WMO of the PFS Division. Analytical support was also provided by D. G. Graczyk and T. TenKate (CMT/AC). Most of the data tables were prepared by Bryan Klimczak and Mark Jilek who are parallel co-op students within ESH. C. L. Cheever (PFS/FPE), Jacob Sedlet, and the ESH staff who contributed to this report, reviewed the draft manuscript, and made a number of constructive comments for which we are grateful. The dedicated effort of Rita M. Beaver (ESH), who typed and prepared the manuscript and performed other tasks needed to complete the report, is greatly appreciated. 


\section{Distribution for ANL-91/3}

\section{Internal:}
C. L. Cheever
M. J. Robinet
T. L. Duffy
R. A. Schlenker
A. J. Dvorak
R. M. Schletter
N. W. Golchert (50)
A. Schriesheim
P. F. Gustafson
J. Sedlet
M. A. Kamiya
V. C. Stamoudis
R. B. Kasper
T. M. Sullivan
R. G. Kolzow
H. C. Svoboda
N. D. Kretz
R. J. Teunis
L. P. Moos (10)
R. E. Toohey
D. M. Nelson
R. A. Wynveen
D. C. Parzyck
ANL Patent Department
D. M. Ray
ANL Contract File
A. S. Reeve
TIS Files (3)
J. G. Riha

\section{External:}

DOE OSTI for distribution per UC-607 (147) ANL - TIS Libraries

DOE-HQ Assistant Secretary for Environment, Safety and Health, EH-1 (2) DOE-HQ Office of Environmental Guidance and Compliance, EH-23 (5) DOE-HQ Office of Environmental Audit, EH-24 (2) DOE-HQ Office of NEPA Project Assistance, EH-25 (2) DOE-HQ Office of Energy Research, James Farley, ER-65 Manager, Chicago Operations Office (10)

A. L. Taboas, DOE-AAO James Benetti, U. S. Environmental Protection Agency, Region 5, Chicago, IL C. D. Bingham, DOE-NBL, Illinois Dave Brekke, Sandia National Laboratory, Livermore, CA Daniel G. Carfagno, Mound Laboratory DuPage County Forest Preserve District DuPage County (IL) Health Department Isabel M. Fisenne, DOE-EML, New York 
R. E. Flowers, DOE-NBL, Illinots

Adolfo Gonzalez, Illinois Environmental Protection Agency, Maywood, IL Daniel A. Gonzalez, Nevada Test Site

William Gunter, U. S. Environmental Protection Agency, Washington, DC (2) Wayne R. Hansen, Los Alamos National Laboratory

James D. Heffner, Westinghouse Savannah River Company

Diana L. Hoff, DOE Idaho Operations Office, Idaho Falls, ID Hue-Su Hwang, Sandia National Laboratory, Alberquerque, NM Illinois Department of Public Health, Springfield, IL Illinois Environmental Protection Agency, Springfield, IL Richard E. Jaquish, Pacific Northwest Laboratory William Laseter, Pantex Plant Illinois Department of Nuclear Safety, Springfield, IL

J. B. McCaslin, Lawrence Berkeley Laboratory

J. R. Naidu, Brookhaven National Laboratory

C. Lyle Roberts, West Valley Demonstration Project, West Valley, NY

Paul Rohwer, Oak Ridge National Laboratory

George H. Setlock, Rocky Flats Plant

Lars Soholt, Los Alamos National Laboratory

Dennis Stevenson, Westinghouse Savannah River Company

David H. Stoltenberg, U. S. Environmental Protection Agency, Region 5, Chicago, IL 

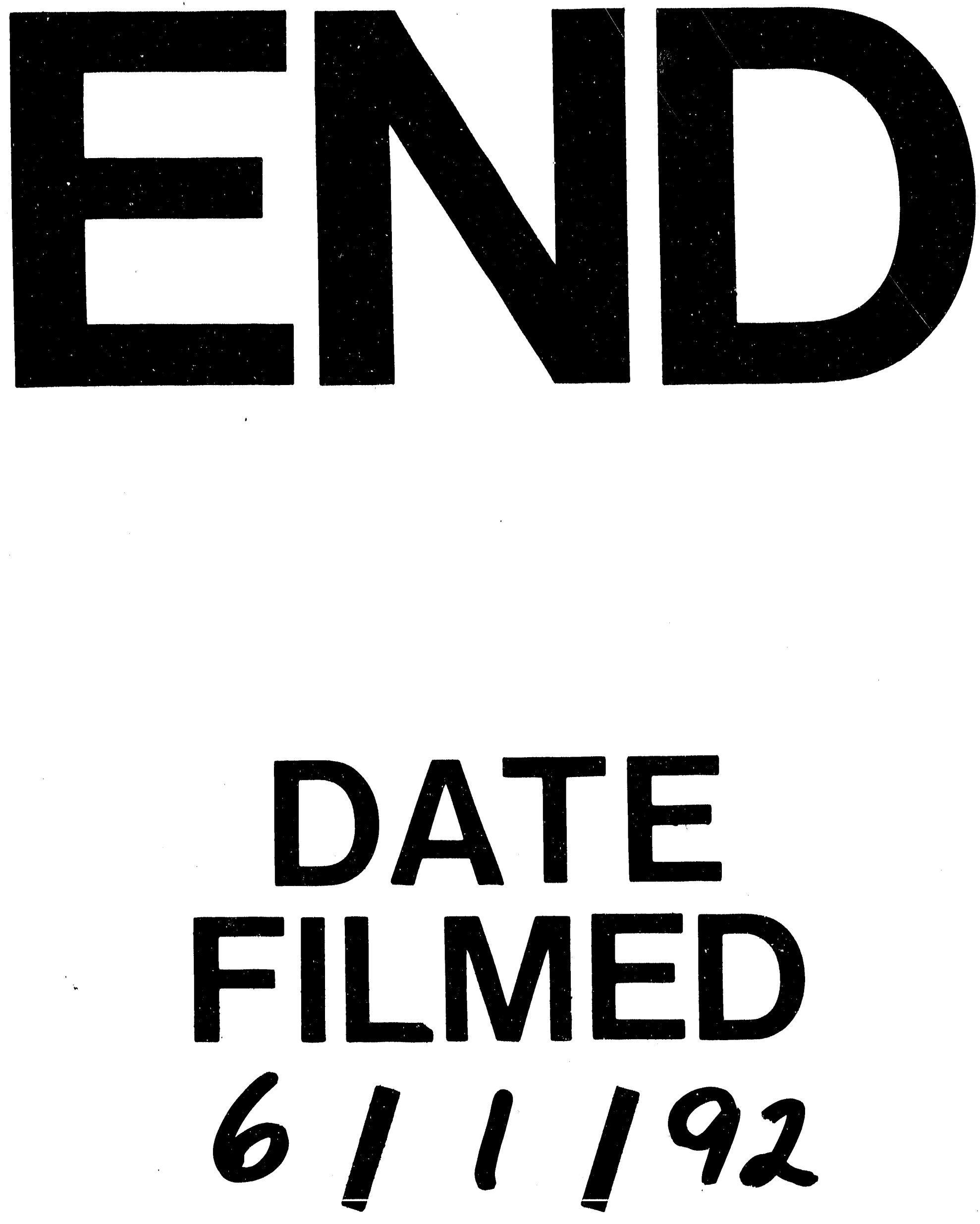
